\title{
Greenland from Archaean to Quaternary Descriptive text to the 1995 Geological map of Greenland, 1:2 500000. 2nd edition
}

Niels Henriksen, A.K. Higgins, Feiko Kalsbeek and T. Christopher R. Pulvertaft 


\section{Geological Survey of Denmark and Greenland Bulletin 18}

\section{Keywords}

Archaean, Caledonides, Cenozoic, economic geology, geological map, Greenland, ice sheet, Mesozoic, offshore, orogenic belts, Palaeozoic, petroleum, Phanerozoic, Proterozoic, sedimentary basins.

\section{Cover illustration}

The cover design depicts mountains of the East Greenland Caledonian fold belt. The view, west of Mestersvig (located on map, page 4 ), is north over Bersærkerbræ and the northern part of the Stauning Alper to Kong Oscar Fjord with Traill $\varnothing$ in the right background. The mountains up to $1800 \mathrm{~m}$ high are of the Neoproterozoic Eleonore Bay Supergroup. To the right: first author Niels Henriksen, for many years head of geological mapping at GGU/GEUS, and participant in field work in Greenland for more than 45 years.

\section{Frontispiece: facing page}

Major Caledonian syncline involving reactivated Archaean basement gneisses containing amphibolite bands. Overlying rusty coloured Mesoproterozoic metasediments (Krummedal supracrustal sequence) just visible in tight core of the fold. The intensity of deformation in the syncline clearly increases towards the core, where the basement gneisses become more strongly foliated. Some of the amphibolite bands were derived from cross-cutting basic intrusions, which are still discernable in the less severely deformed parts of the Archaean basement (Fig. 17, p. 31). The height of the section is $c .2000 \mathrm{~m}$. South-west of innermost Nordvestfjord / Kangersik Kiatteq $\left(c .71^{\circ} 30^{\prime} \mathrm{N}\right)$, Scoresby Sund region, central East Greenland.

Chief editor of this series: Adam A. Garde

Editorial board of this series: John A. Korstgård, Geological Institute, University of Aarhus; Minik Rosing, Geological Museum, University of Copenhagen; Finn Surlyk, Department of Geography and Geology, University of Copenhagen

Scientific editor: Adam A. Garde

Editorial secretaries: Jane Holst and Esben W. Glendal

Referees: C.R.L. Friend (UK), Gordon N. Oakey (Canada) and Henrik Stendal (Greenland)

Illustrations: Eva Melskens, Helle Zetterwall, Lis Duegaard and Jette Halskov

Digital photographic work: Benny M. Schark

Graphic production: Annabeth Andersen

Printers: Rosendahls - Schultz Grafisk, Albertslund, Denmark

Manuscript submitted: 29 May, 2009

Final version approved: 8 October 2009

Printed: 27 November 2009

ISBN 987-87-7871-258-5

ISSN 1604-8156

\section{Citation of the name of this series}

It is recommended that the name of this series is cited in full, viz. Geological Survey of Denmark and Greenland Bulletin. If abbreviation of this volume is necessary, the following form is suggested: Geol. Surv. Den. Green. Bull. 18,126 pp.

\section{Available from}

Geological Survey of Denmark and Greenland (GEUS)

Øster Voldgade 10, DK-1350 Copenhagen K, Denmark

Phone: +45381420 00, fax: +45381420 50, e-mail: geus@geus.dk

or at www.geus.dk/publications/bull

(c) De Nationale Geologiske Undersøgelser for Danmark og Grønland (GEUS), 2009

For the full text of the GEUS copyright clause, please refer to www.geus.dk/publications/bull 


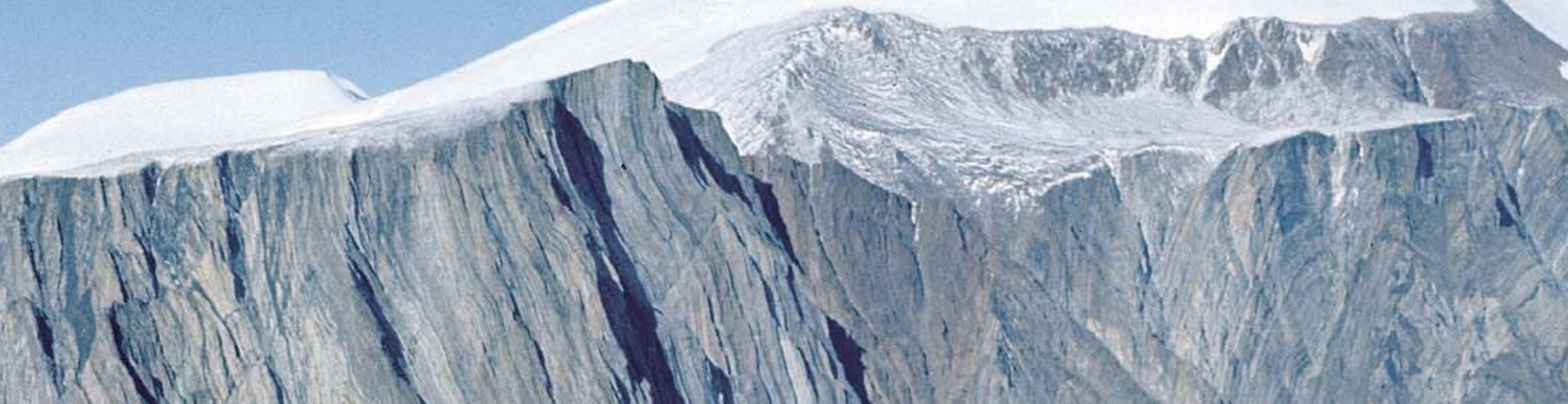

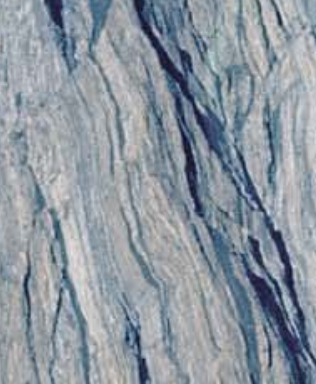

x.

i)

$9+1$

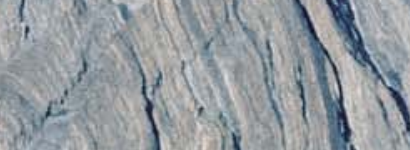

1 $10 y$

Yow

ila

(thon 110

$3=x+10<=0$

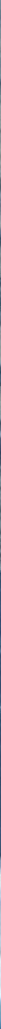




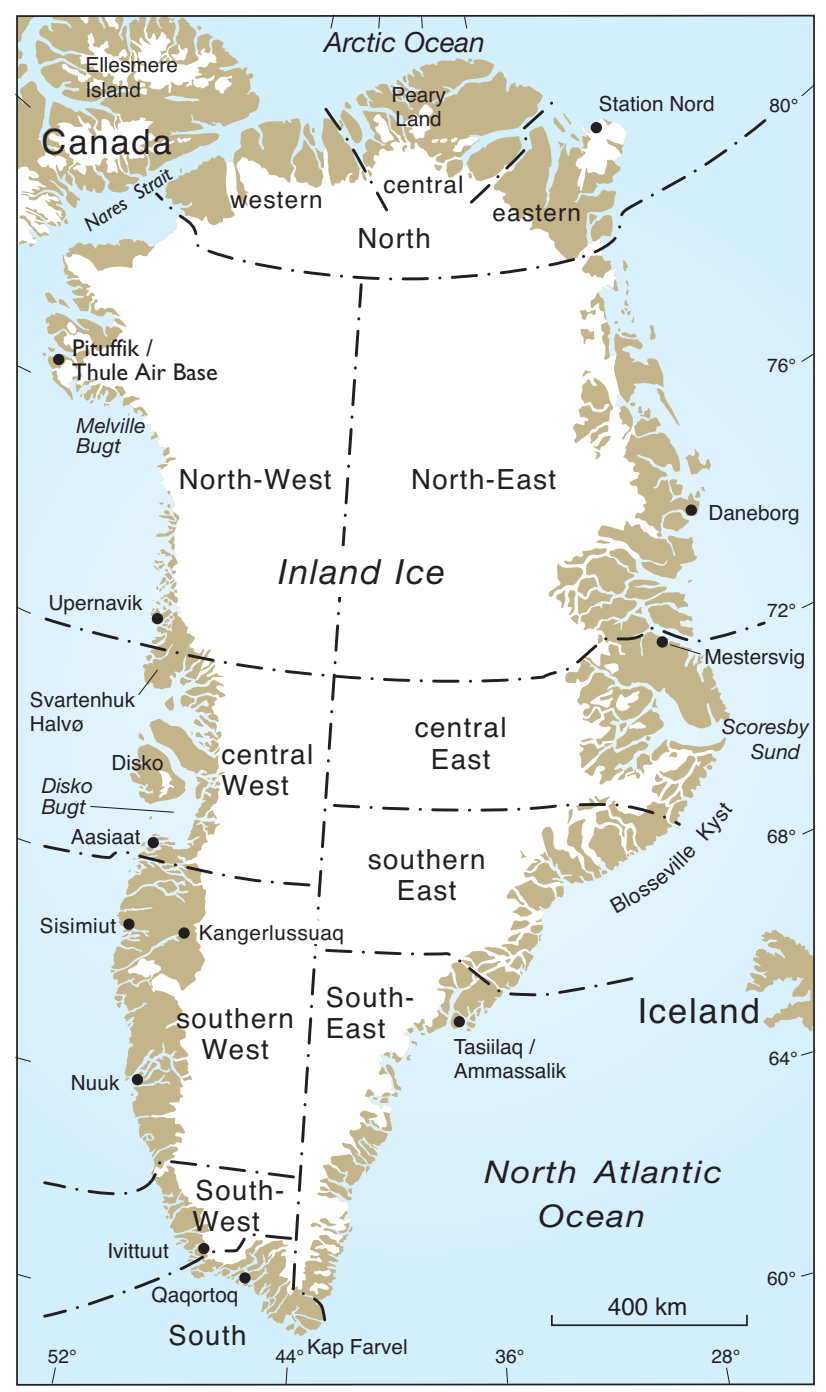

\section{Editorial note}

This bulletin is a revised 2 nd edition of the descriptive text to the Geological map of Greenland 1:2 500 000. The description was first published in 2000 as Geology of Greenland Survey Bulletin 185 by Henriksen et al. 2000. The map, compiled by Escher \& Pulvertaft in 1995 and printed the same year, accompanies the present description.

Since the first edition of this work was published, large amounts of new data have been acquired, especially in the offshore regions, in relation to mineral prospecting and in connection with general geological research mainly in West Greenland. The present description aims at providing an updated overview of the geology of Greenland with reference to the enclosed geological map from 1995 that in general terms is still valid. The first edition included an extensive reference list designed as a key to the most relevant sources for the explanation of the Geological map of Greenland 1:2 500 000. In this second edition the reference list has been expanded with more than

\section{Geographical subdivisions of Greenland used by the Survey}

Map showing the Survey's geographical subdivisions of Greenland, both onshore and offshore, used in this bulletin. Thus Nares Strait, the seaway separating Greenland from Ellesmere Island, Canada, borders North-West Greenland and western North Greenland. However, application of these subdivisions has not been rigorously applied in all parts of the text in order to avoid unwieldy phrases.

It should also be noted that 'West Greenland' and 'East Greenland' are used both as shown on the map (each with two subdivisions, viz. central and southern) and for the entire western and eastern sides of Greenland. In this broader sense, West Greenland covers the four western subdivisions, viz. North-West, central West, southern West and South-West Greenland whereas East Greenland covers the four eastern subdivisions, viz. North-East, central East, southern East and South-East Greenland.

The subdivisions are used throughout the text and also in the Legend explanation (pp. 110-112) and Index (pp. 117-126).
200 new references to cited papers, to give the reader a possibility to follow up on new data and details in agreement with modern interpretations.

The 1:2 500000 map presents a general overview of Greenland geology, but as a basis for this overview there also exists a wealth of more detailed published maps. A set of 14 geological maps at scale 1:500 000 covers the onshore areas of the entire country and a special map at scale 1:1 000000 covers onshore areas in North-East Greenland. In addition to these maps more than 60 geological maps at 1:100 000 have been published, covering mainly areas in central and southern West Greenland. A wide range of special geological and geophysical maps has also been published covering both onshore and offshore areas. Details of all these publications can be obtained from the Survey's website.

For a catalogue of Greenland publications and data see: www.geus.dk/publications/publ-uk.htm. This list will be updated at intervals, when relevant new data become available. 


\section{Contents}

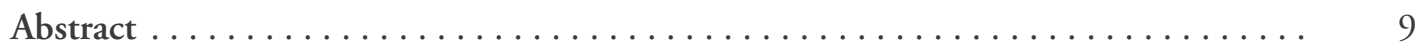

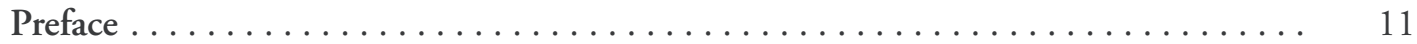

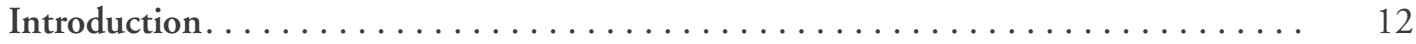

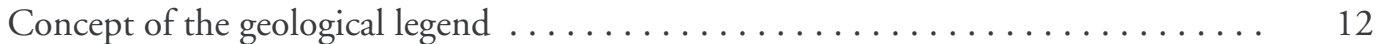

Topographic base .................................. 13

Crystalline rocks older than 1600 Ma: the Greenland Precambrian shield . . . . . . . 14

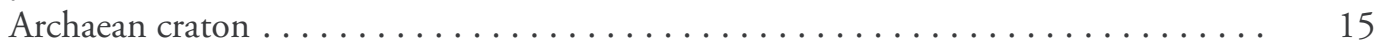

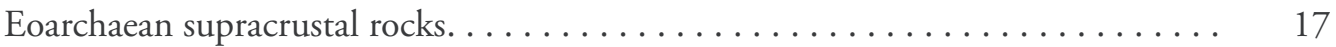

Eoarchaean ('Amîtsoq') gneisses . . . . . . . . . . . . . . . . . . 18

Meso- and Neoarchaean supracrustal rocks. . . . . . . . . . . . . . . . . . . 19

Anorthositic rocks . . . . . . . . . . . . . . . . . . . . . . . . . . . . 19

Meso- and Neoarchaean gneisses . . . . . . . . . . . . . . . . . . . . . . . . . . . . 19

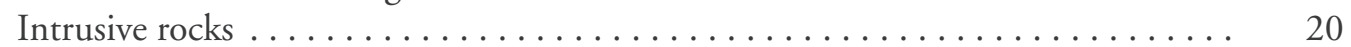

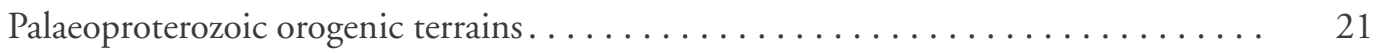

Nagssugtoqidian orogen, West Greenland. . . . . . . . . . . . . . 22

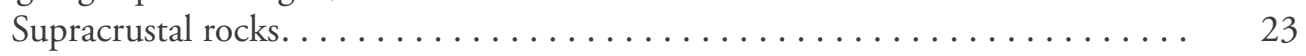

Felsic and intermediate intrusions. . . . . . . . . . . . . . . 24

Nagssugtoqidian orogen in South-East Greenland ................ 24

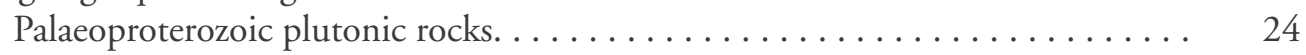

Rinkian fold belt. .................................. 25

Archaean and Palaeoproterozoic supracrustal rocks: Disko Bugt and Nuussuaq . 26

Gneisses and intrusions: Disko Bugt and Nuussuaq .............. 26

Palaeoproterozoic supracrustal rocks north of Nuussuaq: the Karrat Group . . . . 26

Gneisses and intrusive rocks north of Nuussuaq . . . . . . . . . . . 27

North-West Greenland and the Inglefield orogenic belt . . . . . . . . . . 27

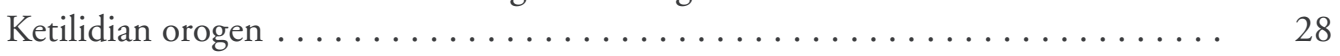

Palaeoproterozoic supracrustal rocks in the northern border zone....... 28

Palaeoproterozoic granitoids and basic-intermediate intrusions,

the Julianehåb batholith . . . . . . . . . . . . . . . . . . . 29

Metasedimentary rocks in the south-eastern part of the Ketilidian orogen . . . . 30

The Ketilidian rapakivi suite. .................... 30

Archaean-Palaeoproterozoic basement in the East Greenland Caledonian orogen. . 31

Archaean-Palaeoproterozoic basement beneath the Inland Ice . . . . . . . . . . 32

Proterozoic to Phanerozoic geological development after formation of the Precambrian shield 33

Palaeo- to Mesoproterozoic unfolded units . . . . . . . . . . . . . . . . 33

Independence Fjord Group, North Greenland ................ 33

Zig-Zag Dal Basalt Formation, North Greenland ............... 33

Correlation with similar rocks in the northernmost part

of the East Greenland Caledonides . . . . . . . . . . . . . . . . . . 35

Gardar Province, South Greenland . . . . . . . . . . . . . . . . . . . . 35

Early Neoproterozoic orogenic units reworked in

the East Greenland Caledonian fold belt $\ldots \ldots \ldots \ldots \ldots \ldots \ldots \ldots \ldots \ldots . \ldots \ldots$

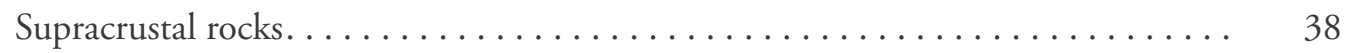

Migmatites and granites . . . . . . . . . . . . . . . . . . 39

Mesoproterozoic - early Neoproterozoic sedimentary basin

in North-West Greenland and Ellesmere Island . . . . . . . . . . . . . . . . . . . 39 
Thule Supergroup $. . . \ldots \ldots \ldots \ldots \ldots \ldots \ldots \ldots \ldots \ldots \ldots . \ldots \ldots$

Neoproterozoic sedimentary basins in North, North-East and East Greenland. . . . . 40

Hagen Fjord Group, North Greenland. . . . . . . . . . . . . . . . . 40

Eleonore Bay Supergroup, East and North-East Greenland ........... 41

Tillite Group, East Greenland . . . . . . . . . . . . . . . . . 42

Sedimentary rocks of unknown age in the East Greenland Caledonides . . . . . . . 43

Carbonatites, kimberlites and associated rocks, West Greenland............ 44

The Palaeozoic Franklinian Basin of North Greenland and Ellesmere Island . . . . . 45

Uppermost Neoproterozoic - Silurian in North Greenland . . . . . . . . . . 45

Proterozoic-Silurian exotic terrane of Ellesmere Island (Pearya) . . . . . . . 48

Ellesmerian orogeny in North Greenland and Ellesmere Island . . . . . . . . . . . 49

Lower Palaeozoic of East Greenland . . . . . . . . . . . . . . . . . 50

Cambrian-Ordovician sediments in the Caledonian fold belt . . . . . . . . 50

Caledonian orogeny in East and North-East Greenland . . . . . . . . . . 50

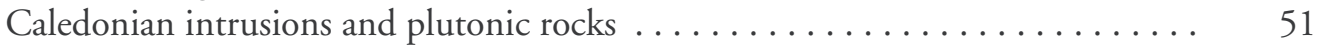

Devonian continental sediments in East Greenland ................ 52

Carboniferous-Tertiary deposits of the Wandel Sea Basin, central

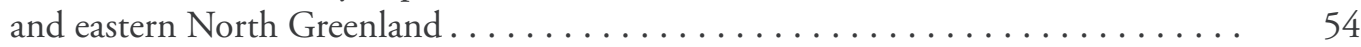

Late Palaeozoic and Mesozoic rift basins in East Greenland . . . . . . . . . . 55

Late Permian - Early Cretaceous deposits of the Jameson Land Basin $\left(70-72^{\circ} \mathrm{N}\right) \quad 55$

Late Permian - Cretaceous deposits in North-East Greenland $\left(72-76^{\circ} \mathrm{N}\right) \ldots \ldots \quad 57$

Cretaceous-Palaeogene deposits . . . . . . . . . . . . . . . . . . . 57

Central West Greenland. . . . . . . . . . . . . . . . . . . . . . 57

Southern East Greenland . . . . . . . . . . . . . . . . . . . . 60

Tertiary volcanics, intrusions and post-basaltic sedimentary rocks $\ldots \ldots \ldots \ldots . \ldots 0$

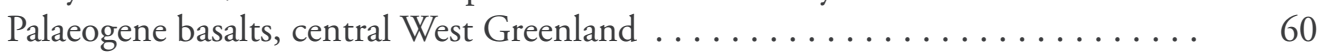

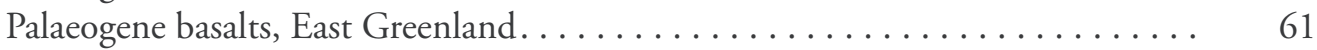

Blosseville Kyst region $\left(68-70^{\circ} \mathrm{N}\right) \ldots \ldots \ldots \ldots \ldots \ldots \ldots \ldots \ldots \ldots \ldots \ldots \ldots \ldots \ldots \ldots$

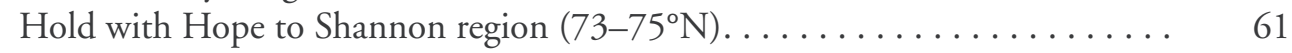

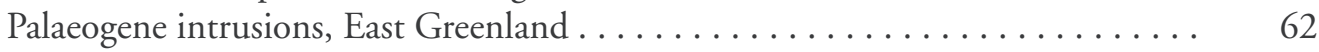

Post-basaltic Palaeogene sedimentary rocks, East Greenland............ 62

Pliocene-Pleistocene sediments, central North Greenland ............. 62

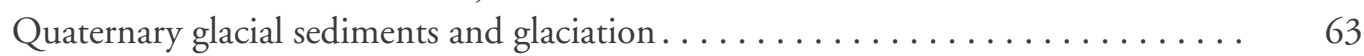

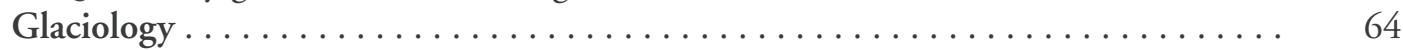

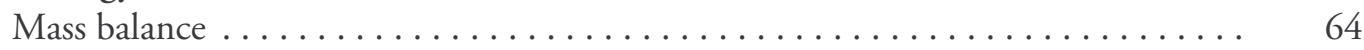

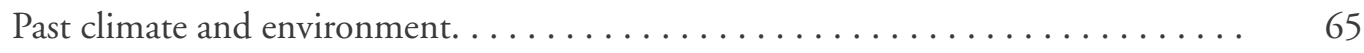

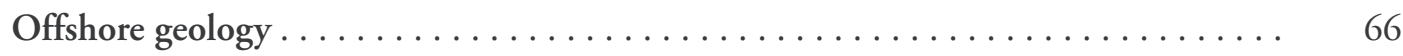

The continental margin off East and North Greenland .............. 66

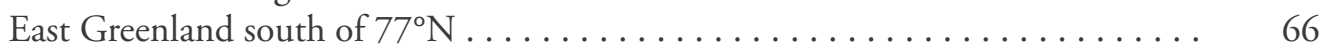

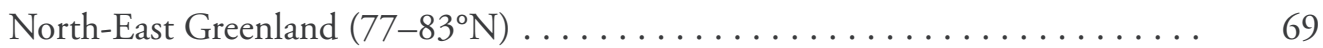

The Morris Jesup Rise and the Yermak Plateau $\ldots \ldots \ldots \ldots \ldots \ldots \ldots . \quad 70$

The continental margin off West Greenland. . . . . . . . . . . . . . 70

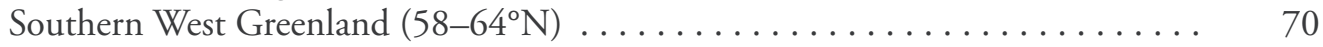

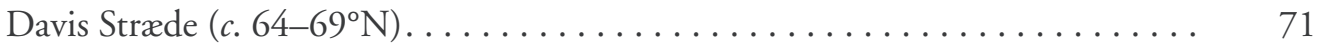

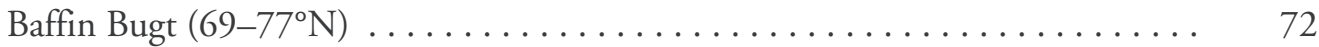

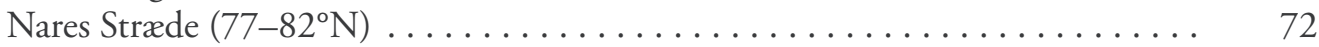

The continental margin off North Greenland, west of the Morris Jesup Rise . . . . . 73

Offshore sedimentary basins. . . . . . . . . . . . . . . . . . . 73

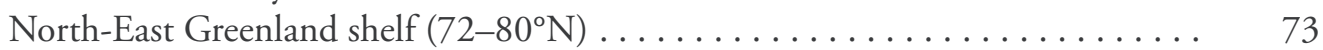

Liverpool Land Basin, central East Greenland $\left(69^{\circ} 30^{\prime}-72^{\circ} \mathrm{N}\right) \ldots \ldots \ldots \ldots . . .675$ 
Blosseville Kyst Basin, East Greenland $\left(67-69^{\circ} 30^{\prime} \mathrm{N}\right) \ldots \ldots \ldots \ldots \ldots \ldots \ldots$

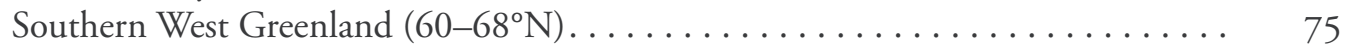

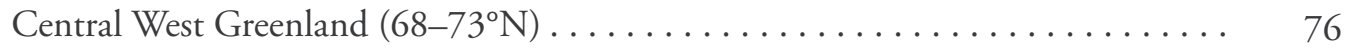

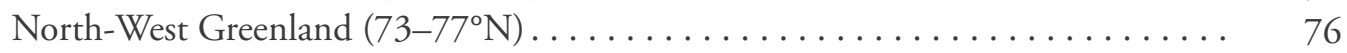

Offshore North Greenland; the Lincoln Sea Basin . . . . . . . . . . . . . . . 77

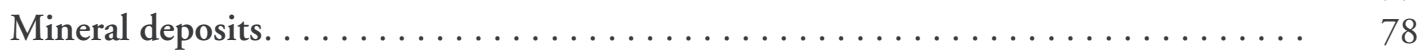

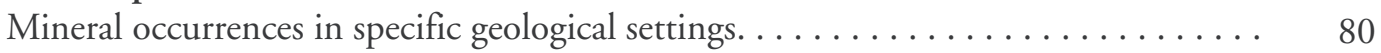

Archaean-Palaeoproterozoic high-grade regions . . . . . . . . . . . . . 80

Mesoproterozoic intracratonic intrusions . . . . . . . . . . . . . . 82

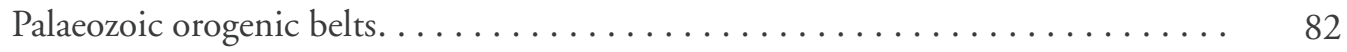

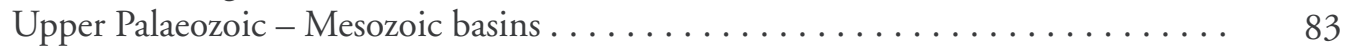

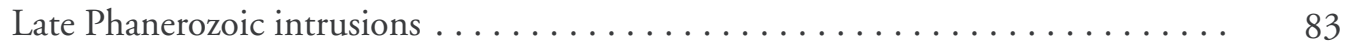

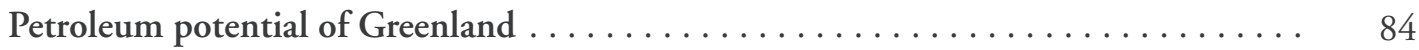

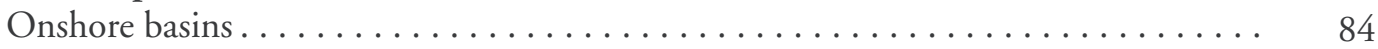

Franklinian Basin, North Greenland $\left(80-83^{\circ} \mathrm{N}\right) \ldots \ldots \ldots \ldots \ldots \ldots \ldots . \ldots \ldots$

Late Palaeozoic - Mesozoic basins, eastern North Greenland $\left(80-83^{\circ} \mathrm{N}\right) \ldots \ldots . .64$

Late Palaeozoic - Mesozoic rift basins, North-East Greenland $\left(72-76^{\circ} \mathrm{N}\right) \ldots \ldots$.

Jameson Land Basin, central East Greenland $\left(70^{\circ} 30^{\prime}-72^{\circ} \mathrm{N}\right) \ldots \ldots \ldots \ldots \ldots . . \ldots 6$

Cretaceous-Palaeogene basin, central West Greenland $\left(69-72^{\circ} \mathrm{N}\right) \ldots \ldots \ldots \ldots$

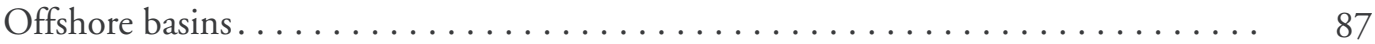

North-East Greenland shelf $\left(75-80^{\circ} \mathrm{N}\right) \ldots \ldots \ldots \ldots \ldots \ldots \ldots \ldots \ldots \ldots \ldots \ldots \ldots$

Liverpool Land Basin, central East Greenland $\left(69^{\circ} 30^{\prime}-72^{\circ} \mathrm{N}\right) \ldots \ldots \ldots \ldots \ldots . \ldots . \ldots 8$

Blosseville Kyst Basin, East Greenland $\left(67-69^{\circ} 30^{\prime} \mathrm{N}\right) \ldots \ldots \ldots \ldots \ldots \ldots \ldots . \ldots . \ldots . \ldots 8$

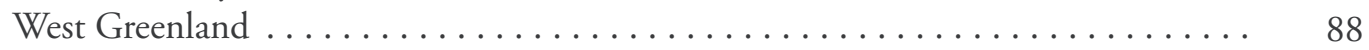

South and South-West Greenland $\left(c .57-62^{\circ} \mathrm{N}\right) \ldots \ldots \ldots \ldots \ldots \ldots \ldots \ldots \ldots$

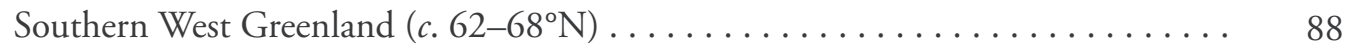

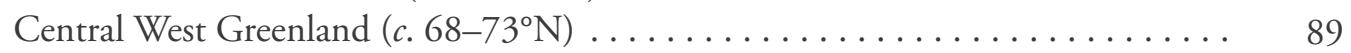

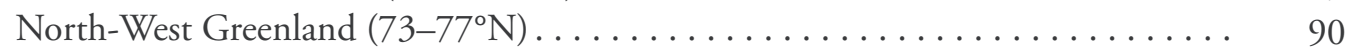

Western North Greenland (north of $\left.80^{\circ} \mathrm{N}\right) \ldots \ldots \ldots \ldots \ldots \ldots \ldots \ldots \ldots \ldots$

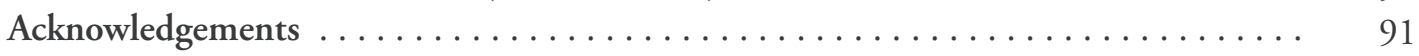

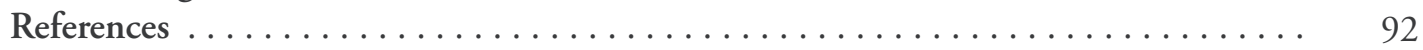

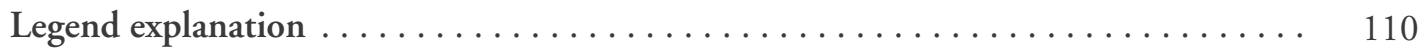

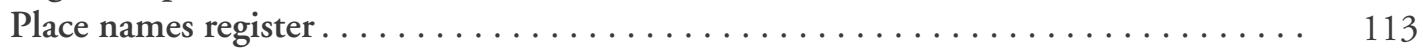

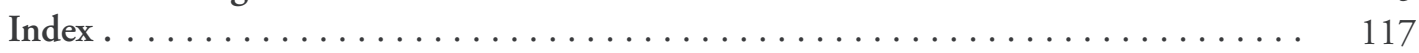

Enclosure: Geological map of Greenland, 1:2 $500000 \ldots \ldots \ldots \ldots \ldots \ldots$ in pocket 



\section{Abstract}

Henriksen, N., Higgins, A.K., Kalsbeek, F. \& Pulvertaft, T.C.R. 2009: Greenland from Archaean to Quaternary. Descriptive text to the 1995 Geological map of Greenland, 1:2 500000.

2nd edition.

Geological Survey of Denmark and Greenland Bulletin 18, 126 pp. + map.

The geological development of Greenland spans a period of nearly $4 \mathrm{Ga}$, from Eoarchaean to the Quaternary. Greenland is the largest island on Earth with a total area of $2166000 \mathrm{~km}^{2}$, but only c. $410000 \mathrm{~km}^{2}$ are exposed bedrock, the remaining part being covered by a major ice sheet (the Inland Ice) reaching over $3 \mathrm{~km}$ in thickness. The adjacent offshore areas underlain by continental crust have an area of $c .825000 \mathrm{~km}^{2}$.

Greenland is dominated by crystalline rocks of the Precambrian shield, which formed during a succession of Archaean and Palaeoproterozoic orogenic events and stabilised as a part of the Laurentian shield about $1600 \mathrm{Ma}$ ago. The shield area can be divided into three distinct types of basement provinces: (1) Archaean rocks (3200-2600 Ma old, with local older units up to $>3800$ $\mathrm{Ma}$ ) that were almost unaffected by Proterozoic or later orogenic activity; (2) Archaean terrains reworked during the Palaeoproterozoic around 1900-1750 Ma ago; and (3) terrains mainly composed of juvenile Palaeoproterozoic rocks (2000-1750 Ma in age).

Subsequent geological developments mainly took place along the margins of the shield. During the Proterozoic and throughout the Phanerozoic major sedimentary basins formed, notably in North and North-East Greenland, in which sedimentary successions locally reaching $18 \mathrm{~km}$ in thickness were deposited. Palaeozoic orogenic activity affected parts of these successions in the Ellesmerian fold belt of North Greenland and the East Greenland Caledonides; the latter also incorporates reworked Precambrian crystalline basement complexes.

Late Palaeozoic and Mesozoic sedimentary basins developed along the continent-ocean margins in North, East and West Greenland and are now preserved both onshore and offshore. Their development was closely related to continental break-up with formation of rift basins. Initial rifting in East Greenland in latest Devonian to earliest Carboniferous time and succeeding phases culminated with the opening of the North Atlantic Ocean in the late Paleocene. Sea-floor spreading was accompanied by extrusion of Palaeogene (early Tertiary) plateau basalts in both central West and central-southern East Greenland.

During the Quaternary Greenland was almost completely covered by ice, and the present day Inland Ice is a relic from the Pleistocene ice ages. Vast amounts of glacially eroded detritus were deposited on the continental shelves around Greenland.

Mineral exploitation in Greenland has so far encompassed cryolite, lead-zinc, gold, olivine and coal. Current prospecting activities in Greenland are concentrated on gold, base metals, platinumgroup elements, molybdenum, iron ore, diamonds and lead-zinc. Hydrocarbon potential is confined to the major Phanerozoic sedimentary basins, notably the large basins offshore North-East and West Greenland. While reserves of oil or gas have yet to be found, geophysical data combined with discoveries of oil seeps onshore have revealed a considerable potential for offshore oil and gas.

Authors' address

Geological Survey of Denmark and Greenland, Øster Voldgade 10, DK 1350 Copenhagen K, Denmark.

E-mail: nielshen@mail.dk 


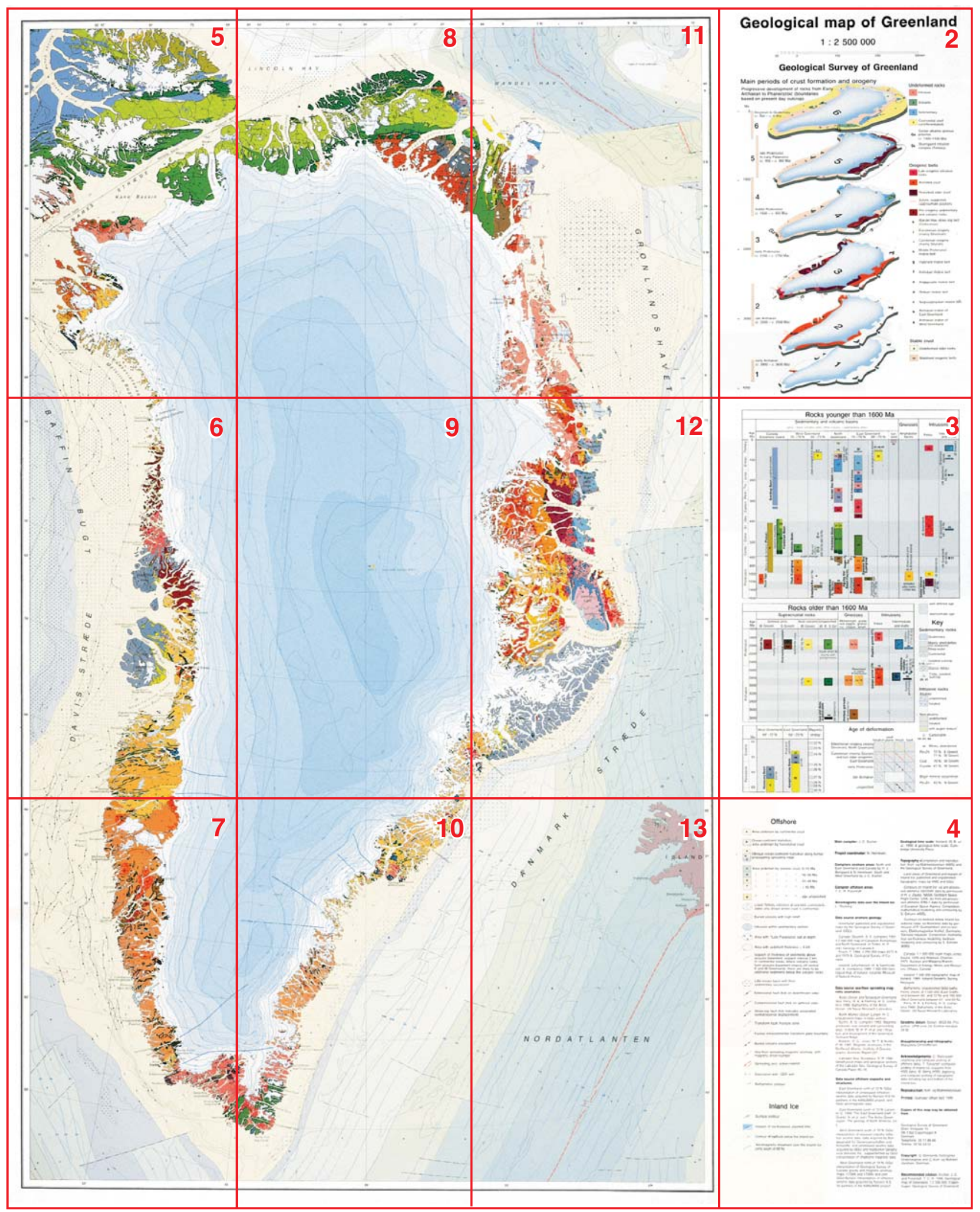

Fig. 1. Index map of the Geological map of Greenland, 1:2 500 000, showing segments 2-13, so numbered in the atlas version of the map (for atlas format, see p. 11). Segment 1 - the title page of the atlas - is not shown. 


\section{Preface}

Greenland is the largest island on Earth with a surface area of more than two million square kilometres. It is up to $1250 \mathrm{~km}$ from east to west and $2675 \mathrm{~km}$ from north to south, extending over almost 24 degrees of latitude; the northern extremity is the northernmost land area in the world. The Inland Ice, the large central ice sheet which covers about $1756000 \mathrm{~km}^{2}$ (c. 81\%) of Greenland, has a maximum thickness of $c .3 .4 \mathrm{~km}$. The ice-free strip of land surrounding the Inland Ice, in places up to $300 \mathrm{~km}$ wide, has an area of $c .410000 \mathrm{~km}^{2}$; this is approximately $30 \%$ more than that of the British Isles. This ice-free zone is generally very well exposed and yields a wealth of geological information, notably in fjord walls and in mountainous areas; even lowland areas only have a limited vegetation cover due to the arctic setting. The area of Greenland's continental shelf that is underlain by continental crust is estimated to be approximately $825000 \mathrm{~km}^{2}$.

Geological observations in Greenland began with the first scientific expeditions; these reached West and East Greenland in the early 1800s and North Greenland in the late 1800 s and early 1900s. Systematic geological mapping commenced in East Greenland with Lauge Koch's 'Danish Expeditions to East Greenland', which lasted from 1926 until 1958 and were mainly concentrated in the region $72-76^{\circ} \mathrm{N}$. In West Greenland systematic geological investigations began in 1946 with the foundation of Grønlands Geologiske Undersøgelse (GGU - the Geological Survey of Greenland); work was initially concentrated in West Greenland but was subsequently extended to all parts of Greenland. Comprehensive investigations by GGU expanded to include not only geological mapping, but a wide range of geochemical, geophysical and glaciological studies both onshore and offshore. In 1995 GGU was merged with Danmarks Geologiske Undersøgelse (DGU - the Geological Survey of Denmark) to form the present Survey, De Nationale Geologiske Undersøgelser for Danmark og Grønland (GEUS - the Geological Survey of Denmark and Greenland). The broad range of geological activities in Greenland previously undertaken by GGU continues to be carried out by GEUS.

When GGU published the first general geological map of all of Greenland at scale 1:2 500000 in 1970, representation of the geology was restricted to onshore areas; relatively little was then known of the offshore geology. During the past almost 40 years the offshore areas surrounding Greenland have been investigated by airborne and ship borne geophysical surveys operated by the Survey, by other scientific institutions and by commercial companies. When the new edition of the geological map was printed in 1995 enough was known to enable an interpretation of the offshore geology to be presented on the map, although it was emphasised that for some of the remote areas offshore North Greenland knowledge was very limited. Since 1995 a considerable amount of new information has been collected from the offshore areas. The new knowledge is reported in the chapter on offshore geology in the present description. There is a high petroleum exploration interest in many of the offshore sedimentary basins, and geological knowledge of the offshore areas has been considerably augmented as a result of commercial exploration.

The Geological map of Greenland, 1:2 500 000, printed in 1995 , is available in three formats:

1. A wall map (sheet size $96 \times 120 \mathrm{~cm}$ ).

2. A folded map sheet $(24 \times 20 \mathrm{~cm}$, as in the pocket of this bulletin).

3. An atlas of numbered segments $(24 \times 20 \mathrm{~cm}$ when closed. An index to the 12 numbered segments of the map is shown as figure 1 .

The description of the map has been prepared with the needs of the professional geologist in mind; it requires knowledge of geological principles but not previous knowledge of Greenland geology. Throughout the text, reference is made to the key numbers in the map legend representing geological units and indicated in square brackets [ ] (see legend explanation, p. 110), while a place names register (p. 113) and an index (p. 117) include place names, geological topics, stratigraphic terms and units found in the legend. The extensive reference list is intended as a key to the most relevant information sources. The text has been compiled by N. Henriksen. Principal contributors include: N. Henriksen (several sections and illustrations); A.K. Higgins (Neoproterozoic - Lower Palaeozoic in North Greenland and Palaeozoic fold belts in North and North-East Greenland); F. Kalsbeek (Precambrian shield and Palaeo- Mesoproterozoic deposits in North Greenland); T.C.R. Pulvertaft (offshore geology). Chapters which have been much revised have been externally reviewed (Precambrian shield by C.R.L. Friend; offshore geology by G.N. Oakey and mineral deposits and petroleum potential by $\mathrm{H}$. Stendal). 


\section{Introduction}

A general overview of the geology of the whole of Greenland in the form of a coloured map sheet, the tectonic/geological map of Greenland, was published by the Geological Survey of Greenland (GGU) in 1970 at a scale of 1:2 500000 . Subsequently, much new information became available as a result of new systematic geological mapping in the ice-free land areas, notably in North, North-East and South-East Greenland, while offshore areas were investigated by a series of seismic, gravimetric and aeromagnetic surveys. The Inland Ice was also further investigated in the period 1970-1995 by regional satellite and airborne radar surveys as well as by ground studies and deep drilling through the more than $3000 \mathrm{~m}$ thick central part of the ice sheet. At the time of compilation in 1995 the map therefore included much new information from the ice-free land areas, and the offshore regions were represented for the first time on a map at this scale. For the Inland Ice new representations of the upper and lower surface of the ice sheet were shown by contours, together with its calculated thickness. However, between 1995 and 2009 much additional information has been collected especially from the offshore regions, and as a consequence the enclosed geological map of Greenland, 1:2 500000 does not represent a fully up-to-date expression of the present knowledge on the geology. The 1995-depiction of the ice-free land areas is in general terms still satisfactory, as well as the representation of the Inland Ice. It is mainly in the offshore regions that new information has been added since 1995, and these developments are described in the chapters on offshore geology and petroleum potential of Greenland. Another field with new developments is that of mineral occurrences, which are addressed in the chapter on mineral deposits.

In order to relate the geology of Greenland to neighbouring countries within the borders of the map sheet, the geology of the adjacent areas of Canada and Iceland has been included, based on published maps (see map legend).

The geology of the ice-free land areas on the 1:2 500000 scale map has been compiled as a conventional bedrock geological map, together with representations of the major tectonic features in the orogenic belts. The presentation of the geology of offshore areas follows a different concept, as interpretations are based on geophysical information. Onshore superficial deposits of Quaternary age have been shown only where extensive areas of bedrock are covered. In many regions dykes are a prominent element of the geology, but as they only form a minor proportion of the exposures they cannot generally be represented at the scale of the map. A compilation of dykes of different ages is shown in this volume as Fig. 20 (p. 37).

The Inland Ice and the many local ice caps and glaciers are shown as one unit. The sea ice, which covers substantial parts of the oceans bordering North and East Greenland for much of the year, is not depicted on the map.

The term 'Tertiary' and division of the Proterozoic into early, middle and late, was used in the legend on the printed map in accordance with the standards of the early 1990s. In the present revised edition of the map description the current conventions of Palaeogene/Neogene and Palaeo-, Meso- and Neoproterozoic are introduced. In the Precambrian descriptions the prefixes 'early', 'middle' and 'late' have been modernised to the subdivisions Eo, Palaeo, Meso and Neo for both Archaean and Proterozoic time and rock units.

\section{Concept of the geological legend}

Two different legend concepts have been used - one for the onshore ice-free areas and one for the offshore regions.

In the legend for the ice-free land areas a distinction has been made between rocks older and younger than $1600 \mathrm{Ma}$. In the older group, which mainly comprises crystalline rocks of the stable Precambrian Greenland shield, the rock units are distinguished according to their lithology and age; the extent of regional tectono-metamorphic provinces is also depicted. Rocks younger than $1600 \mathrm{Ma}$ are shown in relation to the formation of sedimentary basins and orogenic belts along the margins of the stable shield. The principal subdivisions depicted on the map illustrate the general depositional environment, age and extent of the main sedimentary and volcanic basins and, in the Franklinian Basin in North Greenland, the overall depositional setting. Younger crystalline gneisses and plutonic rocks are distinguished by lithology and age of orogenic formation and emplacement. A schematic chronological representation of the geological units shown on the map forms the basic division of the map legend. 
The structures and the ages of deformation in the various orogenic belts are shown by structural trend lines and major tectonic features by appropriate symbols. Most orogenic belts are of composite origin and may incorporate older crystalline rocks and structures. It is often difficult or impossible to distinguish between the older and younger structural elements, and therefore only the signature for the youngest orogenic event has been used within a specific fold belt. Post-orogenic undeformed rocks can be recognised by the absence of overprints of structural symbols.

A cartoon of the crustal evolution of Greenland is shown above the legend. Six stages of evolution are shown from the Eoarchaean to the Cenozoic. These show the distribution in time and space of the orogenic belts and the stepwise growth of the stable crust. The post-orogenic development of sedimentary basins and volcanic provinces is also shown, together with the approximate extent of continental crust around Greenland.

The legend concept for the offshore areas was based on geological interpretation of the available geophysical data. Distinction is made between areas underlain by continental and oceanic crust, respectively; a transition zone is also recognised. Areas with oceanic crust are further subdivided into time slices of $15 \mathrm{Ma}$ based on magnetic anomaly patterns. Magnetic anomaly lines with chron numbers are shown, together with spreading axes and transform faults. Major sedimentary basins are indicated by isopachs showing the sediment thickness superimposed on a representation of crustal type. Volcanic rocks exposed on the seabed (mostly Palaeogene in age) are also shown. An updated overview map of the offshore regions is shown on pp. 68 and 85 .

\section{Topographic base}

The topographic base for the 1:2 500000 geological map has been drawn on the basis of fixed points established throughout Greenland by Kort \& Matrikelstyrelsen, Denmark (KMS - the National Survey and Cadastre, which incorporates the former Geodetic Institute). The map is constructed as a UTM projection in zone 24 with WGS 84 datum; the central meridian is $39^{\circ} \mathrm{W}$. Photogrammetric constructions by KMS and GGU have been combined and co-ordinated to produce the first geometrically correct topographic representation of all of Greenland. All previous maps have suffered to varying degrees from insufficient ground control, especially in North Greenland where errors in the location of topographic features of up to $25 \mathrm{~km}$ occur on older maps. Height contours have been omitted on the ice-free land areas to avoid obscuring the geological detail, but they are shown on the Inland Ice.

Place names are indicated in both their Greenlandic and Danish forms, the Greenlandic names with the new orthography as approved by the Greenland Place Names Authority. A register of place names used on the map is given on p. 113.

The bathymetry of the offshore areas has been compiled from various sources. The available material is very heterogeneous, ranging from very detailed navigation maps by the Royal Danish Hydrographic Office (now part of KMS) to generalised small-scale international oceanographic maps. Information from the ice-covered regions off North and East Greenland is limited; hydrographic representations from these areas should therefore be viewed with reservation.

A topographic map of Greenland at a scale of 1:2500 000 was published by KMS in 1994 (KMS 1994). The enclosed Geological map of Greenland at the same scale uses an identical topographic base map with the same projection; the only significant topographical difference is the omission of contour lines on the land areas. Based on the digital data for the topographic map, the size of Greenland and its ice cover has been computed by Weng (1995). The area figures are:

$\begin{array}{lr}\text { Ice-free land area } & 410449 \mathrm{~km}^{2} \\ \text { Ice-covered area } & 1755637 \mathrm{~km}^{2} \\ \text { Total area } & 2166086 \mathrm{~km}^{2}\end{array}$




\section{Crystalline rocks older than 1600 Ma: the Greenland Precambrian shield}

About half of the ice-free area of Greenland consists of Archaean and Palaeoproterozoic crystalline basement rocks, mainly orthogneisses with enclaves of supracrustal rocks. They belong to three distinct kinds of basement provinces (Fig. 2): (1) Archaean rocks (3200-2600 Ma with local older units, up to $>3800 \mathrm{Ma}$ in the Godthåbsfjord region), strongly deformed during the Archaean but almost unaffected by Proterozoic or later orogenic activity; (2) Archaean terrains reworked during the Palaeoproterozoic around 1900-1800 Ma ago; (3) terrains mainly composed of juvenile Palaeoproterozoic rocks (2000-1750 Ma). Terrains of categories (2) and (3) often

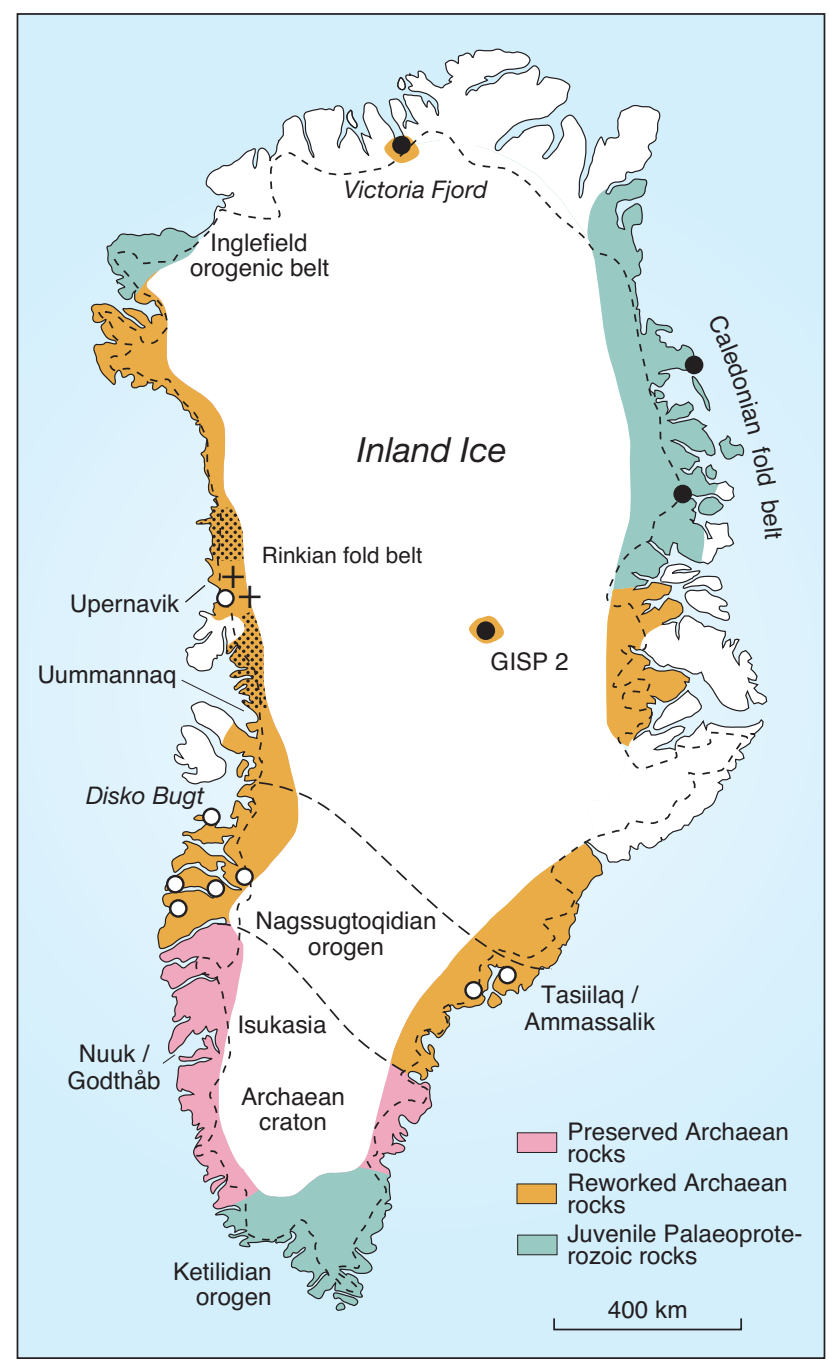

contain high-grade Palaeoproterozoic metasedimentary successions.

Nearly all unreworked Archaean gneisses occur within the Archaean craton of southern Greenland (Fig. 2). They are cut by swarms of mafic dykes (see Fig. 20), most of which were emplaced between 2200 and 2000 $\mathrm{Ma}$ ago; these dykes are generally undeformed and unmetamorphosed, demonstrating that the surrounding gneisses cannot have been significantly affected by Palaeoproterozoic orogenic activity 1900-1800 Ma ago.

Reworked Archaean orthogneisses are prominent in the Nagssugtoqidian orogen and the Rinkian fold belt north of the Archaean craton in West Greenland, and in the Ammassalik region in South-East Greenland (Fig. 2). Reworked Archaean gneisses are also exposed in a small area at Victoria Fjord in northernmost Greenland ( $c$. $3400 \mathrm{Ma}$, Nutman et al. 2008a) and similar rocks have been found at a locality beneath the Inland Ice by drilling (Weis et al. 1997).

Juvenile Palaeoproterozoic gneisses and granitoid rocks (2000-1750 Ma) make up most of the Ketilidian orogen of South Greenland and parts of the Inglefield orogenic belt in North-West Greenland. They also form a large proportion of the crystalline basement within the Caledonian orogen of North-East Greenland.

Before the opening of the Labrador Sea and Baffin Bugt the Precambrian basement of Greenland formed an integral part of the Laurentian shield. A recent interpretation of the relationships between geological provinces in eastern Canada and Greenland (St-Onge et al. 2009) is shown in Fig. 3.

Fig. 2. Simplified map showing the distribution of Archaean and Palaeoproterozoic basement provinces in Greenland. Large areas within the Rinkian fold belt are dominated by metasedimentary rocks (..: Karrat Group) and granites (+: Prøven igneous complex). Black dots and open circles indicate localities where the presence of, respectively, Archaean and Palaeoproterozoic rocks have been documented in poorly known areas, as well as in cases where these ages are in contrast to the age of the surrounding rocks. Slightly modified from Kalsbeek (1994). 


\section{Archaean craton}

Together with smaller areas along the coast of Labrador and in north-western Scotland, the Archaean rocks of southern Greenland (Figs 2, 3) form the North Atlantic craton. The Greenland Archaean is largely made up of tonalitic to granodioritic orthogneisses [72, 73], amphibolites [68] and anorthositic rocks [85]. Most of these rocks are of Meso- to Neoarchaean age, 3200-2600 Ma, but Eoarchaean orthogneisses [76] and supracrusal rocks [69] (3850-3600 Ma) are widely exposed in the Godthåbsfjord region.

Before geochronological data became more widely available, the whole of the Greenland Archaean craton was envisaged to represent a more or less homogeneous geological entity. Detailed field investigations combined with $\mathrm{U}-\mathrm{Pb}$ zircon age determinations, however, have

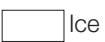

Mesoproterozoic-Phanerozoic

$\square$ Palaeogene magmatic province

Phanerozoic orogens and basins

Neoproterozoic-Palaeozoic basins

Grenville orogen

Gardar igneous province and Seal Lake Group

Mesoproterozoic plutonic suites

Palaeo- to Neoproterozoic basins

\section{Palaeoproterozoic}

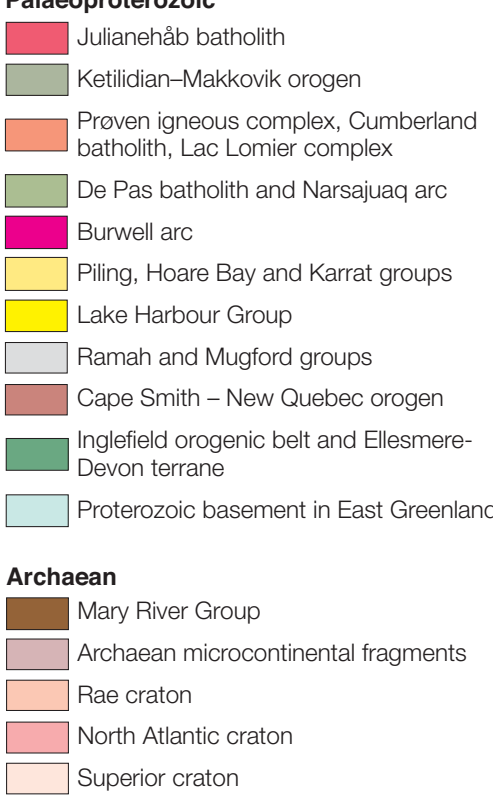

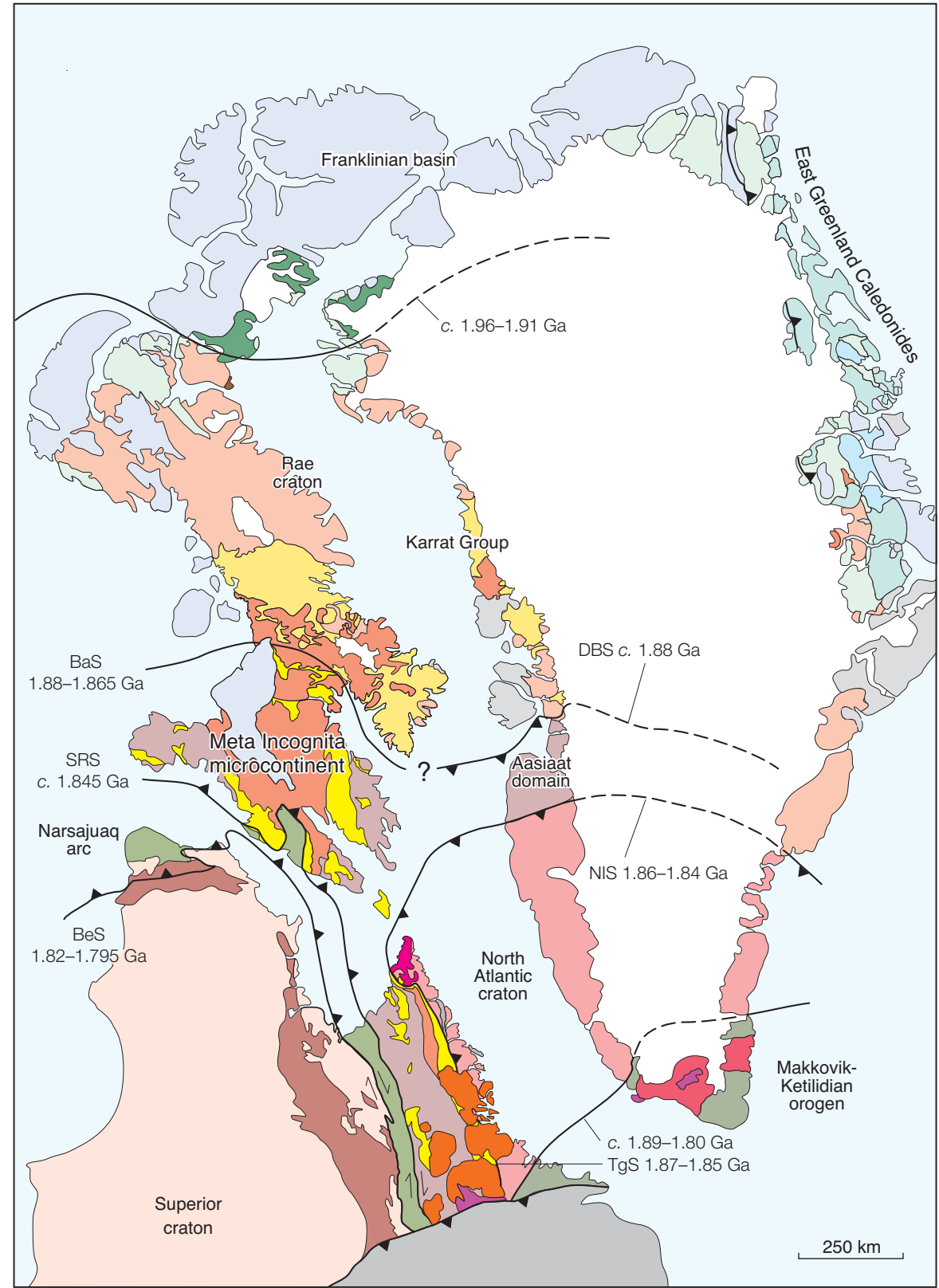

Fig. 3. Map showing the presently preferred correlation of principal geological units of eastern Canada and Greenland, shown with Greenland in its pre-drift (pre-late Cretaceous) position relative to eastern Canada, simplified after St-Onge et al. (2009).

BaS: Baffin suture; BeS: Bergeron suture; DBS: Disko Bugt suture; NIS: Nordre Isortoq steep belt; SRS: Soper River suture; TgS: Tasiuyak gneiss suture. The approximate ages of the different sutures illustrate the progressive accretion of crustal blocks from north to south in Greenland during the Palaeoproterozoic. For details see St-Onge et al. (2009) and papers referred to therein. 


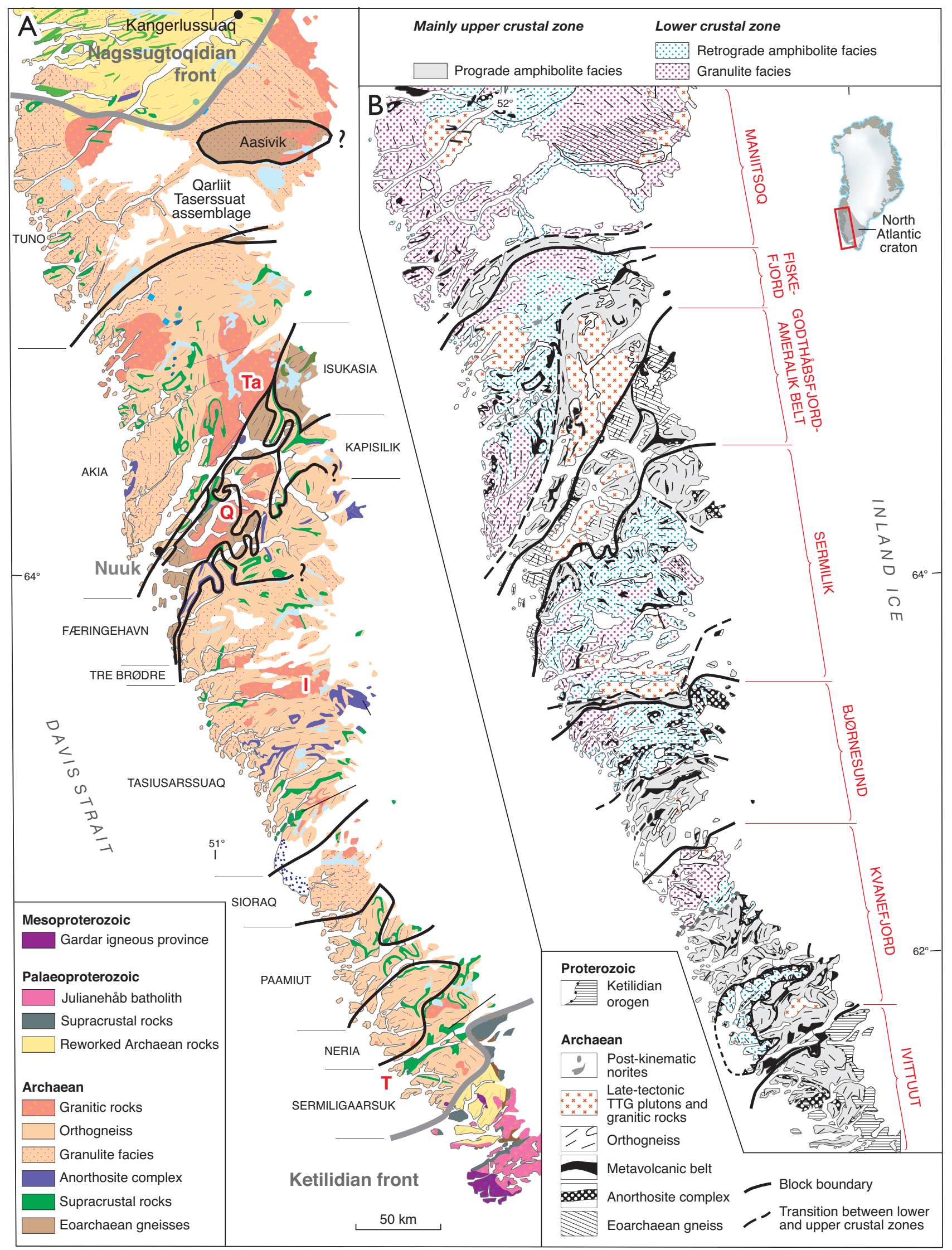

Fig. 4. Maps of the Archaean craton, southern West Greenland. A: The subdivision in terranes/blocks with distinct geological histories (see text) after Friend \& Nutman (2001). T, Târtoq Group; I, Ilivertalik augen granite; Q, Qôrqut granite complex; Ta, Taserssuaq tonalite. B: The subdivision in tilted blocks, each of which has granulite facies rocks in its northern parts and rocks at amphibolite facies in the south after Windley \& Garde (2009). 
shown that areas with contrasting tectonometamorphic histories ('terranes') occur side by side, separated by folded mylonite zones (Friend et al. 1987, 1988). In the Godthåbsfjord region Friend et al. (1987) recognised three such terranes, the Færingehavn, Tre Brødre, and Tasiusarssuaq terranes, each with its characteristic rock association and metamorphic history. The subdivision of the Godthåbsfjord region into terranes has since been repeatedly revised and refined as more geochronologic information became available (e.g. Friend \& Nutman 2005; Nutman \& Friend 2007). The validity of the terrane model has locally been verified (Crowley 2002) but elsewhere questioned (Hanmer et al. 2002). After its introduction in the Godthåbsfjord region the terrane model has also been applied to other parts of the Archaean craton (Friend \& Nutman 2001), see Fig. 4A. Because of the large areal extent of the Archaean rocks many details of the subdivision of the craton into terranes are still to be clarified. The different terranes are envisaged once to have formed independent crustal blocks (perhaps fragments of an earlier Archaean continent) that were amalgamated during the Neoarchaean.

Recently, Windley \& Garde (2009) have subdivided the Archaean craton of western Greenland into six slightly tilted blocks, separated by shear zones, each of which expose granulite facies rocks in the north and (prograde) amphibolite facies rocks in the south (Fig. 4B). Rock units interpreted as remnants of island arcs are exposed in supracrustal belts in the low-grade parts of these blocks. Rocks retrograded from granulite facies to amphibolite facies commonly occur in the northern and central parts of these blocks. The paper of Windley \& Garde (2009) contains an extensive overview of research carried out in the region.

\section{Eoarchaean supracrustal rocks}

The Isua supracrustal sequence [69] (3700-3800 Ma, Moorbath et al. 1973) in the Isukasia area (Fig. 2) at the head of Nuup Kangerlua/Godthåbsfjord is the most extensive occurrence of Eoarchaean supracrustal rocks known on Earth. It forms a zone up to $4 \mathrm{~km}$ wide and up to $c .35 \mathrm{~km}$ long and has been investigated in considerable detail. A recent review of earlier studies together with new data and geological maps at 1:20 000 is presented by Nutman \& Friend (2009). These authors subdivide the Isukasia area into two tectonic units (terranes), with rocks up to $3700 \mathrm{Ma}$ in the north and $>3800 \mathrm{Ma}$ in the south. The supracrustal rocks comprise: (1) layered and massive amphibolites, within which pillow structures are locally preserved; (2) metacherts and a major body of banded iron formation (Fig. 5); (3) biotitemuscovite schists, some of which preserve graded bedding; (4) units of talc schist, up to $100 \mathrm{~m}$ wide, with relics of dunite; (5) layered carbonate and calc-silicate rocks, strongly affected by metasomatic activity and (6) bodies of pale chloritic amphibolite ('garbenschiefer') up to $1 \mathrm{~km}$ wide, which form $c .25 \%$ of the supracrustal belt, and probably represent metasomatically altered metavolcanic rocks. All these rocks have been strongly deformed and metamorphosed at amphibolite facies conditions. Geochemical studies of the least altered amphibolites have shown that they have tholeiitic and boninitic compositions, similar to modern basaltic rocks formed in oceanic island arcs (Polat et al. 2002; Polat \& Hoffman 2003).

Outside the Isukasia area enclaves of supracrustal rocks, mainly amphibolites of tholeiitic or komatiitic composition, occur as thin units within Eoarchaean gneisses. These supracrustal rocks have been collectively

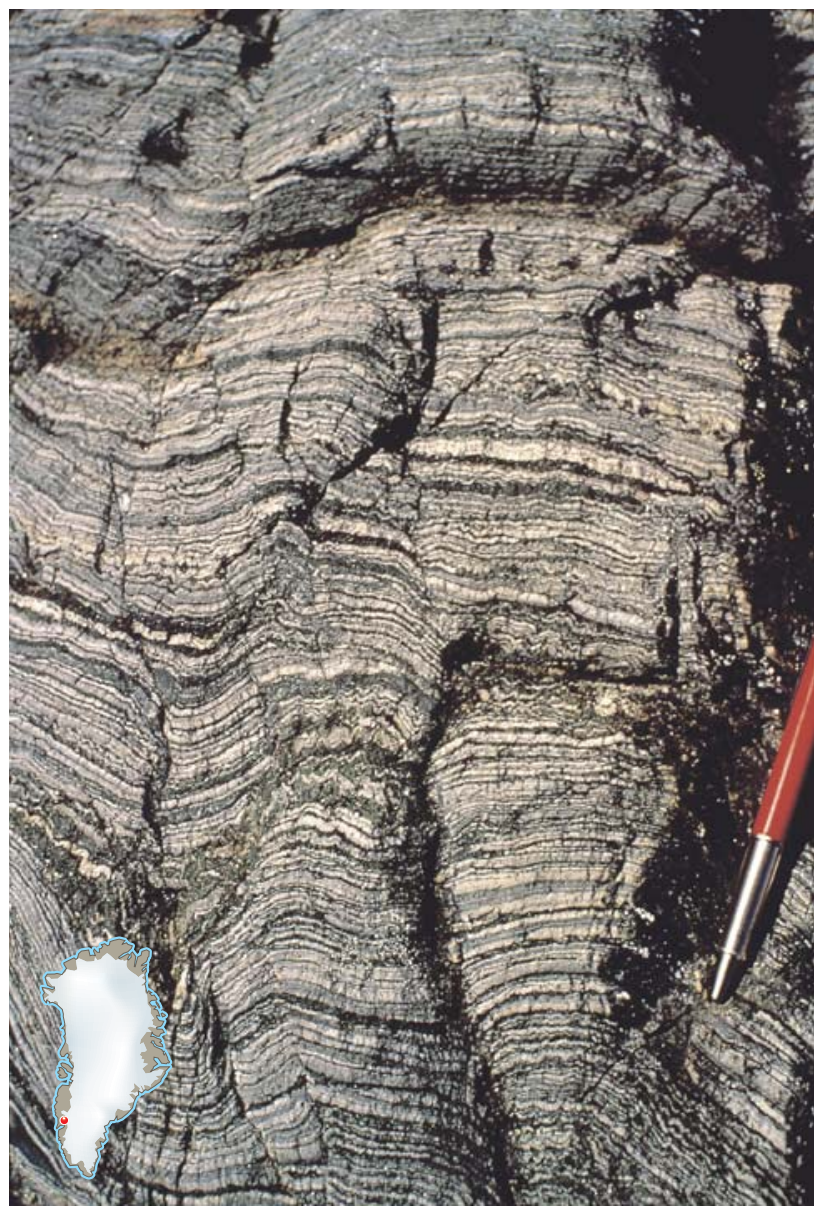

Fig. 5. Eoarchaean banded iron formation consisting of interlayered magnetite (dark layers) and chert (light layers). Isua supracrustal sequence, Isukasia, inner Godthåbsfjord, southern West Greenland. Pen for scale. Photo: A.A. Garde. 
termed the Akilia association [69], and are thought to represent remnants of a disrupted greenstone belt (McGregor \& Mason 1977). Studies of graphite particles in samples of Isua metasedimentary rocks have yielded evidence of very early life on Earth (Rosing 1999).

\section{Eoarchaean ('Amîtsoq') gneisses}

Eoarchaean orthogneisses (Fig. 6), previously known as Amitsoq gneisses and shown under that name on the geological map [76], occur in an area stretching north-east from Nuuk/Godthåb to Isukasia. They are characterised by the presence of abundant remnants of metamorphosed basic dykes (Ameralik dykes, Fig. 20; McGregor 1973). The precursors of the gneisses were formed during a number of distinct intrusive events between $c$. 3800 and $3600 \mathrm{Ma}$ (Moorbath et al. 1972; Nutman et al. 2004). Because of the diversity in age and origin of the Eoarchaean rocks Nutman et al. (1996) introduced the term Itsaq Gneiss Complex to include all Eoarchaean rocks in the Godthåbsfjord region. The term Amîtsoq gneisses is rarely used in newer publications.

Two main types of Eoarchaean orthogneisses (not differentiated on the geological map) can be recognised: (1) Grey, banded to homogeneous tonalitic to granodioritic orthogneisses of calc-alkaline affinity (commonly with secondary pegmatite banding) which form at least $80 \%$ of the outcrop. The oldest of these have been dated at c. $3850 \mathrm{Ma}$ (for overview see Nutman et al. 2004), although these very old dates have been questioned (e.g., Whitehouse et al. 1999); (2) Microcline augen gneisses with associated subordinate ferrodiorites (c. $3600 \mathrm{Ma}$ ), which have been referred to as the Amitsoq iron-rich suite (Nutman et al. 1984). The latter resemble Proterozoic rapakivi granites and were intruded after strong deformation of the surrounding grey banded gneisses. Most Eoarchaean gneisses are in amphibolite facies, but locally the rocks have been affected by $c$. $3600 \mathrm{Ma}$ granulite facies metamorphism possibly related to emplacement of the Amitsoq iron-rich suite.

After compilation of the geological map Eoarchaean orthogneisses have also been found north of the Godt-

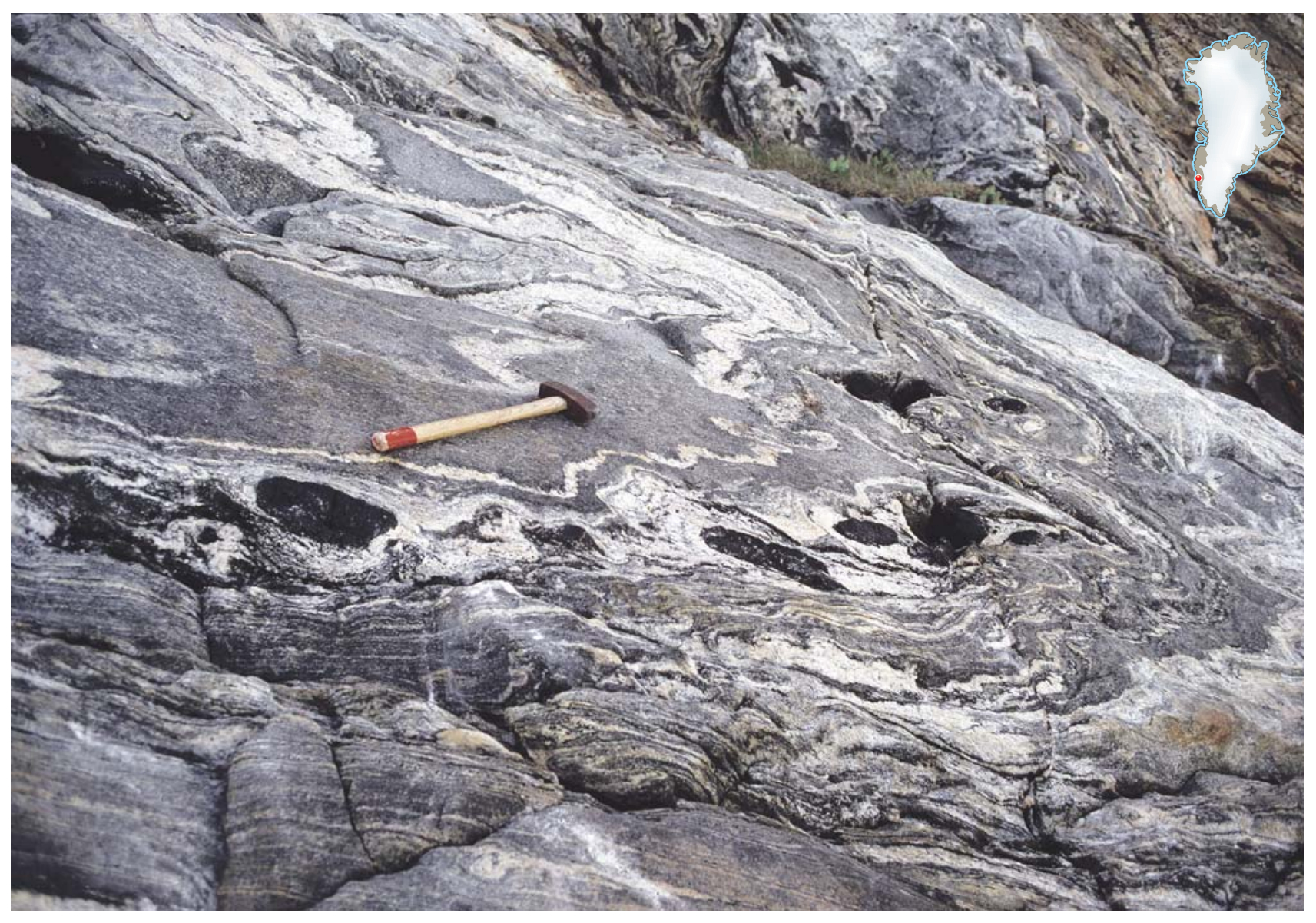

Fig. 6. Heterogeneous, polyphase Eoarchaean (Amîtsoq) gneiss in the central part of northern Godthåbsfjord, southern West Greenland. Fragments of dark homogeneous amphibolite are interpreted as remnants of disrupted mafic (Ameralik) dykes. The hammer is $c .45 \mathrm{~cm}$ long. Photo: A.A. Garde. 
håbsfjord region, at Qarliit Tasersuat $\left(65^{\circ} 49^{\prime} \mathrm{N}, 50^{\circ} 44^{\prime} \mathrm{W}\right)$ and in a larger area east of Sukkertoppen Iskappe, the Aasivik terrane (Rosing et al. 2001; Fig. 4A).

\section{Meso- and Neoarchaean supracrustal rocks}

Ten to twenty per cent of the Archaean craton is made up of a variety of supracrustal rocks [68], mainly amphibolites with subordinate paragneisses (often garnetiferous \pm cordierite \pm sillimanite) and ultramafic layers and pods. Amphibolites represent the oldest rocks recognised within each terrane; primary cover-basement relationships with underlying rocks have not been observed. Few reliable age determinations for these rocks are available, but it is evident that they belong to several different age groups. Amphibolites locally show well-preserved pillow structures indicating a submarine volcanic origin. Intense deformation, however, has generally obliterated all primary structures and produced finely layered amphibolites. More massive amphibolites may represent original basic sills within the volcanic pile. The amphibolites range from andesitic to komatiitic in composition; the majority are chemically similar to low-K tholeiitic basalts.

Two typical examples of Mesoarchaean supracrustal units are: (1) Andesitic metavolcanic rocks in the southeastern Akia terrane (Fig. 4A) that have been dated at 3070 $\mathrm{Ma}$. On the basis of field observations and chemical data they have been interpreted as parts of a Mesoarchaean island arc (Garde 2007a). (2) A several kilometres thick, relatively well preserved succession of supracrustal rocks in the southernmost part of the Archaean craton, the Târtoq Group (T, Fig. 4A; Higgins 1968; Berthelsen \& Henriksen 1975), which consists of metavolcanic greenschists and metasedimentary rocks. While the youngest detrital zircons in a metasedimentary sample are $c .2840$ $\mathrm{Ma}$ (Nutman et al. 2004), greenschists at a different locality are cut by sheets of $2940 \mathrm{Ma}$ tonalite (Nutman \& Kalsbeek 1994). Apparently the Târtoq Group consists of supracrustal packages of varying ages, illustrating once more the geological complexity of the Archaean craton.

Metasedimentary rocks occur only locally. Geochronological data on detrital zircons suggest a variety of ages (Nutman et al. 2004). While the youngest zircons in most of the investigated samples are c. $2800 \mathrm{Ma}$ (in samples from the Godthåbsfjord region $c .3000 \mathrm{Ma}$ ), a sample from Hamborgerland, north of Maniitsoq/Sukkertoppen, has zircons as young as $2720 \mathrm{Ma}$. Eoarchaean zircons are rare or absent in all of the investigated samples, supporting the view that the Eoarchaean terranes were separated from the other terranes until the Archaean craton was united by terrane amalgamation during the Neoarchaean. Most supracrustal units are complexly folded and, since they form good marker horizons, they have been used to reveal the intricate structure of the enveloping gneiss complexes.

\section{Anorthositic rocks}

Metamorphosed calcic anorthosites and associated leucogabbroic, gabbroic and ultramafic rocks [85] form one of the most distinctive rock associations in the Archaean craton. Such rocks are present in all the terranes, and detailed investigation has revealed subtle geochemical variations between anorthosites from different terranes (Dymek \& Owens 2001). Anorthositic rocks occur as concordant layers and trains of inclusions within gneisses, and provide some of the best marker horizons for mapping structures on a regional scale. They are generally bordered by amphibolites into which they are believed to have been intruded.

Anorthosites and associated rocks are most spectacularly developed in the Fiskenæsset area of southern West Greenland where they form $c .5 \%$ of the total outcrop. Here they appear to belong to a single stratiform intrusion, the Fiskenæsset complex (Myers 1985), which has been dated at c. $2850 \mathrm{Ma}$ (Ashwal et al. 1989). The main rock types are metamorphosed anorthosites, leucogabbros and gabbros $(<10 \%, 10-35 \%$ and $35-65 \%$ mafic minerals, respectively), together with minor proportions of ultramafic rocks and chromitite (Ghisler 1976). Although the rocks are commonly strongly deformed, magmatic structures are preserved in low-strain areas: cumulus textures with plagioclase up to $10 \mathrm{~cm}$ in size are common and igneous layering can be observed at many localities. The Fiskenæsset complex has undergone complex folding. The earliest major folds were recumbent isoclines; these were refolded by two later fold phases producing structures with steeply inclined axial surfaces (Myers 1985).

\section{Meso- and Neoarchaean gneisses}

Most of the Archaean craton is composed of Mesoarchaean grey orthogneisses $[72,73]$. In accordance with the notion that the craton comprises a number of individual terranes, variable ages have been reported (for a detailed overview see Windley \& Garde 2009). In the Akia terrane (Fig. 4A) of West Greenland ages up to 
$3220 \mathrm{Ma}$ occur (Garde 1997), whereas farther south isotopic ages are generally less than $3000 \mathrm{Ma}$. The $2825 \mathrm{Ma}$ Ikkattoq gneisses in the Tre Brødre terrane, Godthåbsfjord region (Friend et al. 2009), are an example of these younger gneisses. The Ikkatoq gneisses are mainly of granodioritic composition, with subordinate quartz diorite. $\mathrm{Sm}-\mathrm{Nd}$ isotope data indicate that Eoarchaean sources played a significant role in their petrogenesis.

The igneous precursors of the Archaean gneisses were intruded as sub-concordant sheets and larger complexes that penetrated and disrupted ('exploded') pre-existing basic metavolcanic units and anorthositic rocks (Fig. 7); the gneisses commonly occupy much larger volumes than the older rocks into which they were intruded. Individual gneiss sheets range from a few metres to several kilometres in width. It has been suggested that intrusion of granitoid magmas was associated with periods of thrusting (Bridgwater et al. 1974).

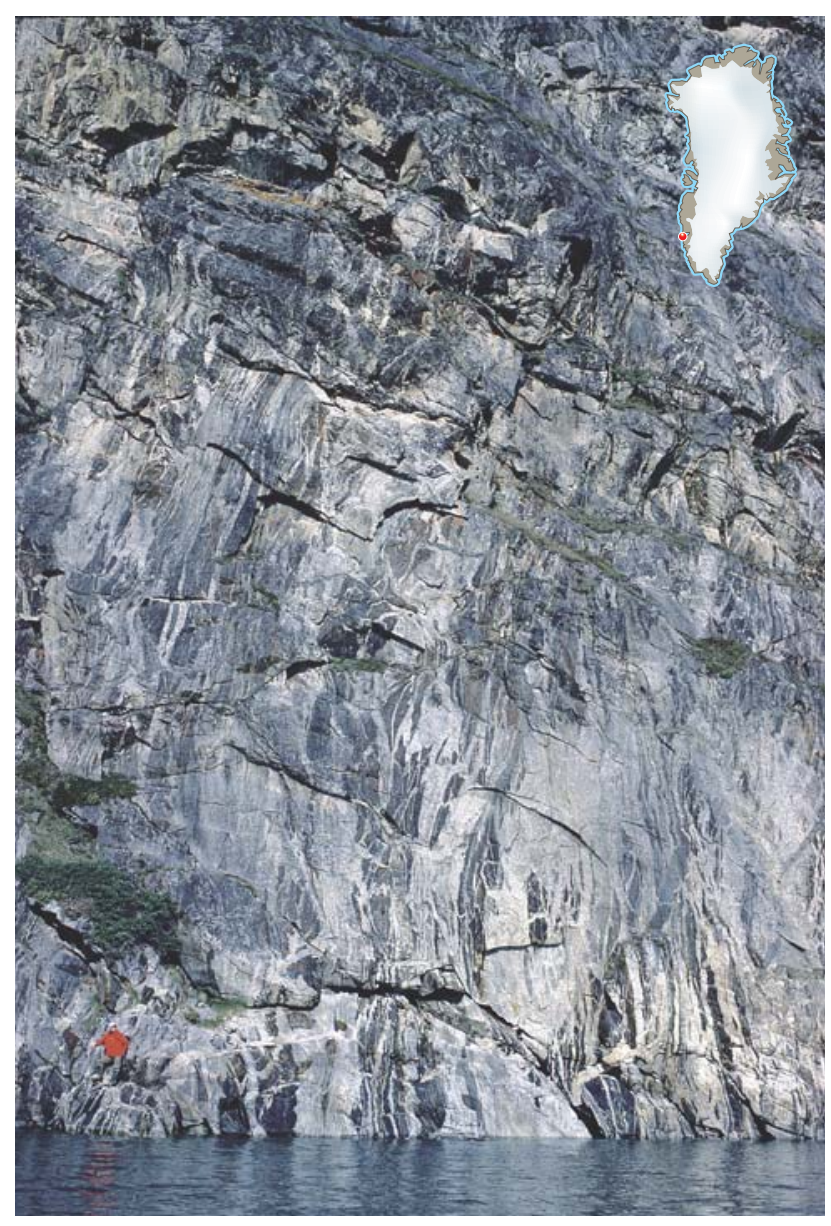

Fig. 7. Amphibolite agmatite with numerous sheets of tonalite, granodiorite, granite and pegmatite, dated at 3.0-2.97 Ga. South-facing, c. $40 \mathrm{~m}$ high cliff in central Godthåbsfjord, southern West Greenland. Person in red anorak for scale. Photo: A.A. Garde.
Most of the gneisses are tonalitic to granodioritic in composition and form typical TTG (Tonalite, Trondhjemite, Granodiorite) suites. A statistical study in the Fiskenæsset area $\left(c .4000 \mathrm{~km}^{2}\right)$ has shown that such gneisses make up $c .85 \%$ of the outcrop area. Tonalitic gneisses (K-feldspar $<10 \%$ ) form $c .57 \%$, granodioritic gneisses (K-feldspar 10-20\%) c. 9\%, and granitic gneisses (K-feldspar $>20 \%$ ) c. $16 \%$ of the terrain (Kalsbeek 1976).

Large parts of the craton are occupied by granulite facies gneisses [73]. Granulite facies metamorphism, however, was not synchronous throughout the area: north of Nuuk/Godthåb it is 3000-3100 Ma (Garde 1990; Friend \& Nutman 1994), whereas in the Fiskenæsset area it is c. $2800 \mathrm{Ma}$ (Pidgeon \& Kalsbeek 1978) and north of Maniitsoq/Sukkertoppen c. $2750 \mathrm{Ma}$ (Friend \& Nutman 1994). Commonly the age of granulite facies metamorphism is similar to that of the igneous precursors of the gneisses. In granulite facies terrains hypersthene is most common in amphibolites, whereas in orthogneisses its presence depends on chemical composition. Regional surveys of stream sediment geochemistry have shown that the distribution of several lithophile elements is strongly correlated with metamorphic facies variations (Fig. 8; Steenfelt 1994).

Two kinds of amphibolite facies gneisses [72] can be distinguished: those formed by retrogression of granulite facies rocks, and those that were formed by prograde metamorphism and never experienced granulite facies conditions. These two kinds have not been differentiated on the geological map because criteria to recognize retrograded granulite facies rocks (McGregor \& Friend 1997) were not available during the early mapping. An overview of the distribution of prograde and retrograde amphibolite facies gneisses in southern West Greenland is presented by Windley \& Garde (2009) and is here shown in Fig. 4B.

Commonly the gneisses show complex fold interference structures (e.g. Berthelsen 1960; Fig. 9). Formation of gneisses by deformation and migmatisation of their igneous precursors has been described in detail by Myers (1978), and a detailed description of the complex evolution of the Fiskefjord area, north of Godthåbsfjord, has been presented by Garde (1997).

\section{Intrusive rocks}

Within the Archaean craton a variety of homogeneous granitic to tonalitic rock units have been differentiated on the map as felsic intrusions [80]. These rocks were emplaced at various times during the tectonic evolution of the areas in which they occur. Some, e.g. the c. 2980 


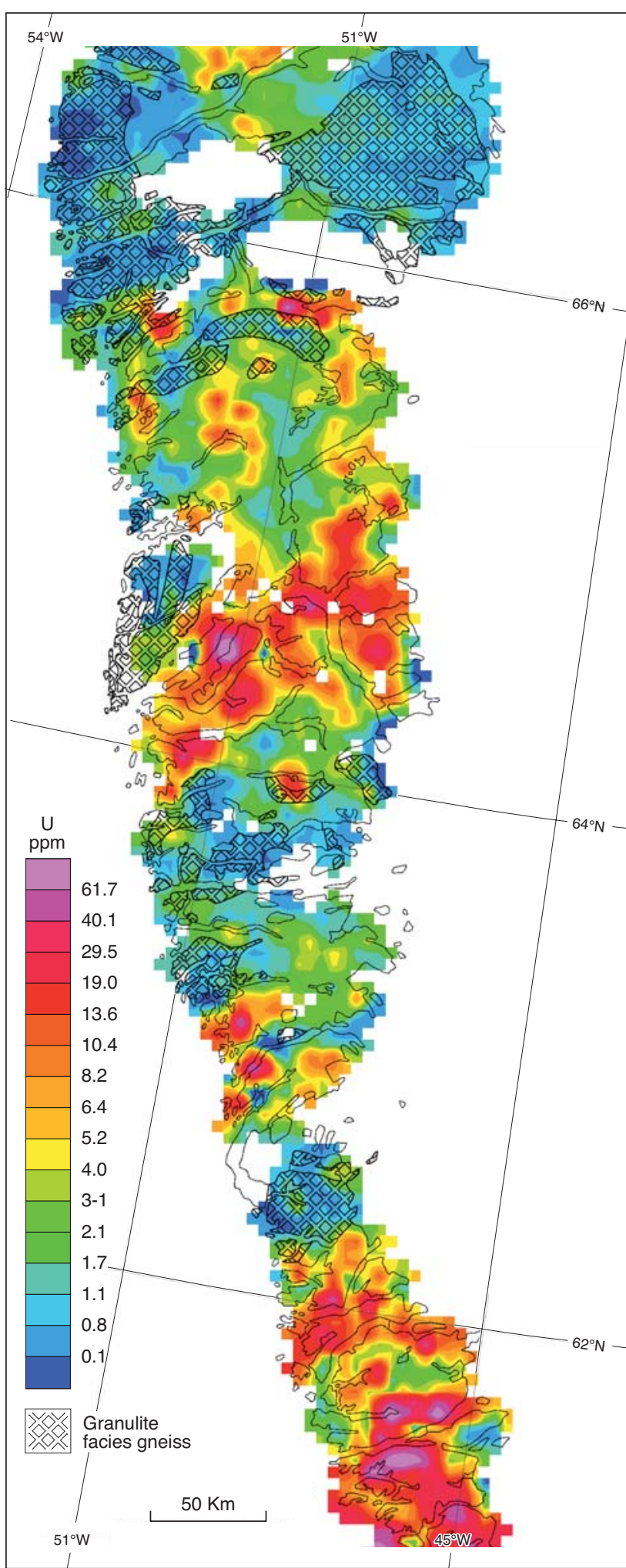

Fig. 8. Map showing the variation in uranium concentrations in the $<0.1 \mathrm{~mm}$ fraction of stream sediments from the Archaean craton of southern West Greenland (Steenfelt 2001). There is a close correlation between $U$ concentrations and the metamorphic grade of the underlying rocks (Fig. 4 B), stream sediments from granulite facies terrains having low $\mathrm{U}$ compared to those from amphibolite grade areas.
Ma Taserssuaq tonalite north of inner Godthåbsfjord (Ta, Fig. 4A; Garde 1997), represent late phases of the igneous precursors of the gneisses in areas where deformation was less intense than elsewhere. Others, e.g. the $2835 \mathrm{Ma}$ Ilivertalik augen granite in the Tasiusarsuaq terrane (I, Fig. 4A; Pidgeon et al. 1976) are younger than the surrounding gneisses, but have been strongly overprinted by later deformation and metamorphism. One rock unit, the $2550 \mathrm{Ma}$ Qôrqut granite complex [79] east of Nuuk/Godthåb (Q, Fig. 4A; Friend et al. 1985), was formed by late crustal melting and is clearly posttectonic.

A distinct 2700 Ma suite of very well-preserved posttectonic intermediate and mafic intrusions, including gabbros and diorites [82] as well as syenites and granites [80], occurs within Archaean gneisses in the Skjoldungen district of South-East Greenland (Nielsen \& Rosing 1990; Blichert-Toft et al. 1995). It is associated with older syenitic gneisses [80] and with a late nephelinite body, the 2670 Ma Singertât complex [83].

Small norite bodies [82] occur within an arcuate belt east of Maniitsoq/Sukkertoppen (Secher 1983), and a small 3007 Ma carbonatite sheet [84] (the oldest carbonatite known on Earth) has been found at Tupertalik, $65^{\circ} 30^{\prime} \mathrm{N}$ in West Greenland (Larsen \& Pedersen 1982; Larsen \& Rex 1992; Bizzarro et al. 2002).

\section{Palaeoproterozoic orogenic terrains}

About forty per cent of the ice-free area of Greenland is underlain by Palaeoproterozoic orogenic terrains (Fig. 2). North of the Archaean craton lies the Nagssugtoqidian orogen, which continues beneath the Inland Ice to South-East Greenland. Still farther north are the Rinkian fold belt and the Inglefield orogenic belt of West and North-West Greenland, and south of the Archaean craton lies the Ketilidian orogen (Fig. 2). The Nagssugtoqidian orogen and Rinkian fold belt largely consist of reworked Archaean rocks that underwent strong deformation and metamorphism during the Palaeoproterozoic 1900-1850 Ma ago, while the Inglefield and Ketilidian orogens contain large proportions of juvenile Palaeoproterozoic crust.

Recent investigations have suggested that the Greenland shield was formed by progressive accretion of crustal blocks, from northernmost Greenland to the south (Nutman et al. 2008b; St-Onge et al. 2009). Archaean rocks of the Rinkian fold belt were united with an Archaean block in northernmost Greenland along the Inglefield orogenic belt around $1920 \mathrm{Ma}$ (Nutman et al. 2008a). Archaean gneisses of the Nagssugtoqidian orogen were then accreted 


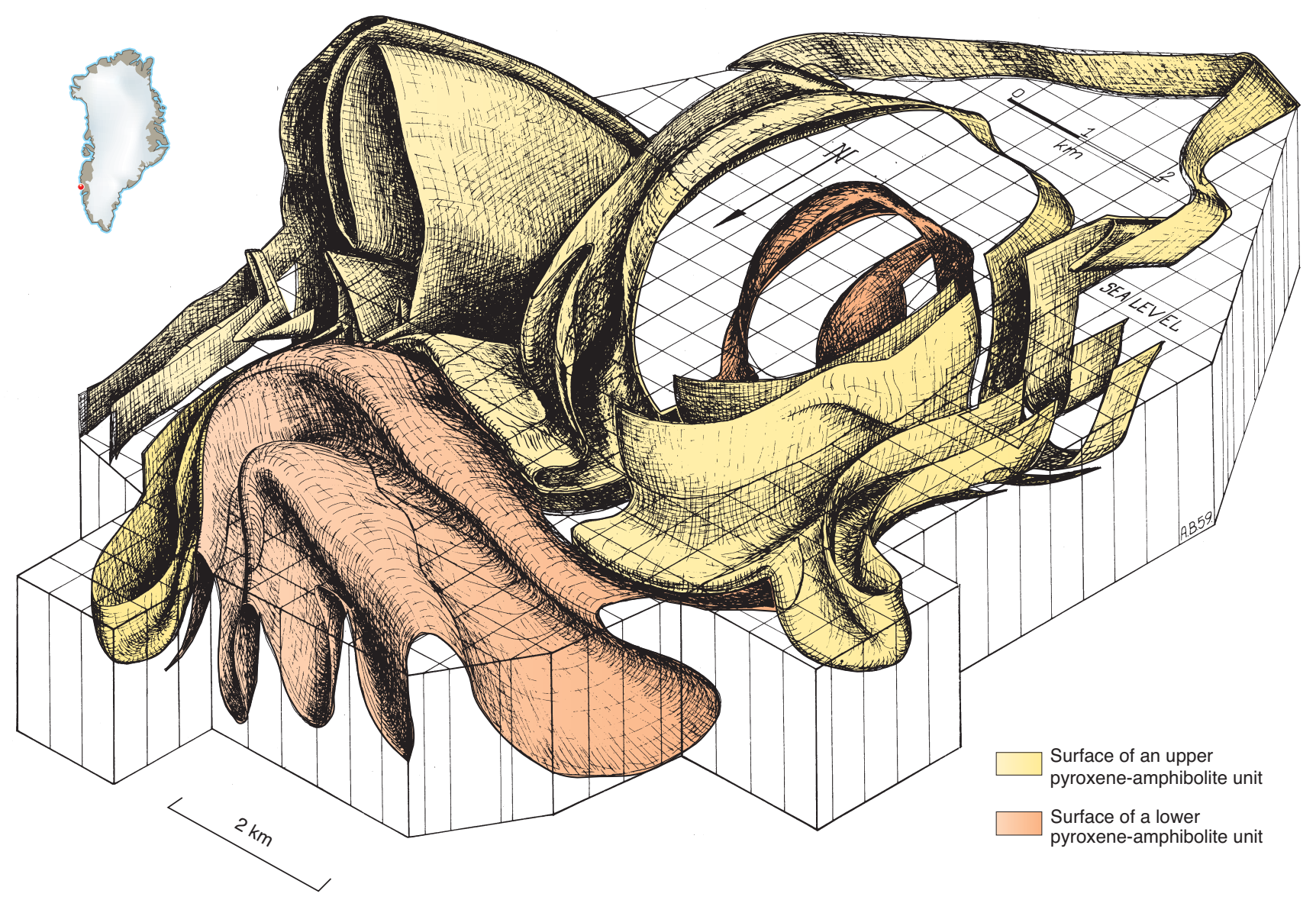

Fig. 9. Structural stereogram of the western Toqqusap Nunaa area north of Atammik (c. $\left.65^{\circ} \mathrm{N}\right)$, southern West Greenland, showing complex fold structures in the late Archaean gneiss complex. Slightly modified from Berthelsen (1960).

to the Rinkian/Inglefield/North Greenland block at $c$. $1870 \mathrm{Ma}$ along a suture within Disko Bugt (Connelly \& Thrane 2005; Thrane et al. 2005; Connelly et al. 2006). Collision within the Nagssugtoqidian orogen followed around $1850 \mathrm{Ma}$ (Connelly et al. 2000), and batholitic rocks of the Ketilidian orogen were accreted to the Archaean craton 1850-1800 Ma ago (Garde et al. 2002). Many details of this process are still uncertain.

The largest area of juvenile Palaeoproterozoic rocks in Greenland $(600 \mathrm{~km}$ along strike and up to $300 \mathrm{~km}$ in width) occurs in the Caledonian thrust sheets of NorthEast Greenland. Its relationships with the other Palaeoproterozoic terrains in Greenland are unknown.

\section{Nagssugtoqidian orogen, West Greenland}

The distinction of the Nagssugtoqidian orogen in West Greenland from the Archaean craton to the south was first noted by Ramberg (1949). A swarm of basic dykes, the Kangâmiut dykes (2040 Ma; Nutman et al. 1999; Mayborn \& Lescher 2006), which are well preserved in the Archaean craton to the south, become increasingly deformed and metamorphosed on entering the Nagssugtoqidian orogen (see Fig. 20). This orogen (Fig. 2; van Gool et al. 2002) extends from Søndre Strømfjord to Disko Bugt in West Greenland and continues southeastwards beneath the Inland Ice to the Ammassalik region in South-East Greenland. It mainly consists of reworked Archaean gneisses [74, 75] (Connelly \& Mengel 2000) but also includes Palaeoproterozoic supracrustal and intrusive rocks $[67,78,81]$. In West Greenland main structures trend ENE-WSW, and the orogen exhibits a number of prominent ENE-trending shear zones (among which is the Nordre Strømfjord shear zone; K. Sørensen et al. 2006) that separate areas characterised by open folding. The peak of Proterozoic tectonic and metamorphic activity was at c. $1850 \mathrm{Ma}$ (Taylor \& Kalsbeek 1990) when large parts of the orogen underwent granulite facies metamorphism. High-grade meta- 
morphism was followed by an extended period of uplift and cooling (Willigers et al. 2002). Palaeoproterozoic orogenic activity is believed to be related to collision of two Archaean continents, with one or more sutures present within the Nagssugtoqidian orogen (Kalsbeek et al. 1987; van Gool et al. 2002; Garde \& Hollis in press). The reconstruction of St-Onge et al. (2009) shown in Fig. 3 displays two main sutures, which delimit an interjacent region termed the Aasiaat domain. The northwestern part of this region appears only to have been little affected by Palaeoproterozoic deformation and metamorphism (e.g. Mazur et al. 2006; Stendal et al. 2006). Tectonically emplaced lenses of metaperidotite of apparent mantle origin are common along thrusts that separate Archaean and Palaeoproterozoic rocks in the central part of the orogen (Kalsbeek \& Manatschal 1999).

\section{Supracrustal rocks}

Palaeoproterozoic supracrustal units, dominated by pelitic and semipelitic metasedimentary rocks, are prominent in the central part of the Nagssugtoqidian orogen [67]. Marble and calc-silicate rocks are common within these units, and pelitic rocks may be rich in graphite. Deposition of these units took place between $c .2000$ and $1920 \mathrm{Ma}$ ago: they are cut by sheets of $1910 \mathrm{Ma}$ quartz diorite, and the youngest detrital zircons are c. $2000 \mathrm{Ma}$ old (Nutman et al. 1999). Small islands NE of Aasiaat/ Egedesminde expose well preserved $c .1850 \mathrm{Ma}$ tholeiitic pillow lavas, chloritic and aluminous shales, manganiferous BIF etc., interpreted to represent ocean floor and distal turbidite deposits (Garde \& Hollis in press).

Within the Nagssugtoqidian orogen Archaean metasedimentary rocks [68] are also present, for example at the southern shore of Disko Bugt (Hollis et al. 2006). They are not easily distinguished in the field from Proterozoic rocks and, since isotopic age determinations were few at the time of map compilation, not all supracrustal sequences shown on the map have been assigned to the correct age category. For example, a metasedimentary unit at Lersletten, south-east of Aasiaat/Egedesminde $\left(68^{\circ} 24^{\prime} \mathrm{N}, 51^{\circ} 14^{\prime} \mathrm{W}\right)$, indicated as Archaean on the geological map, has been shown to be

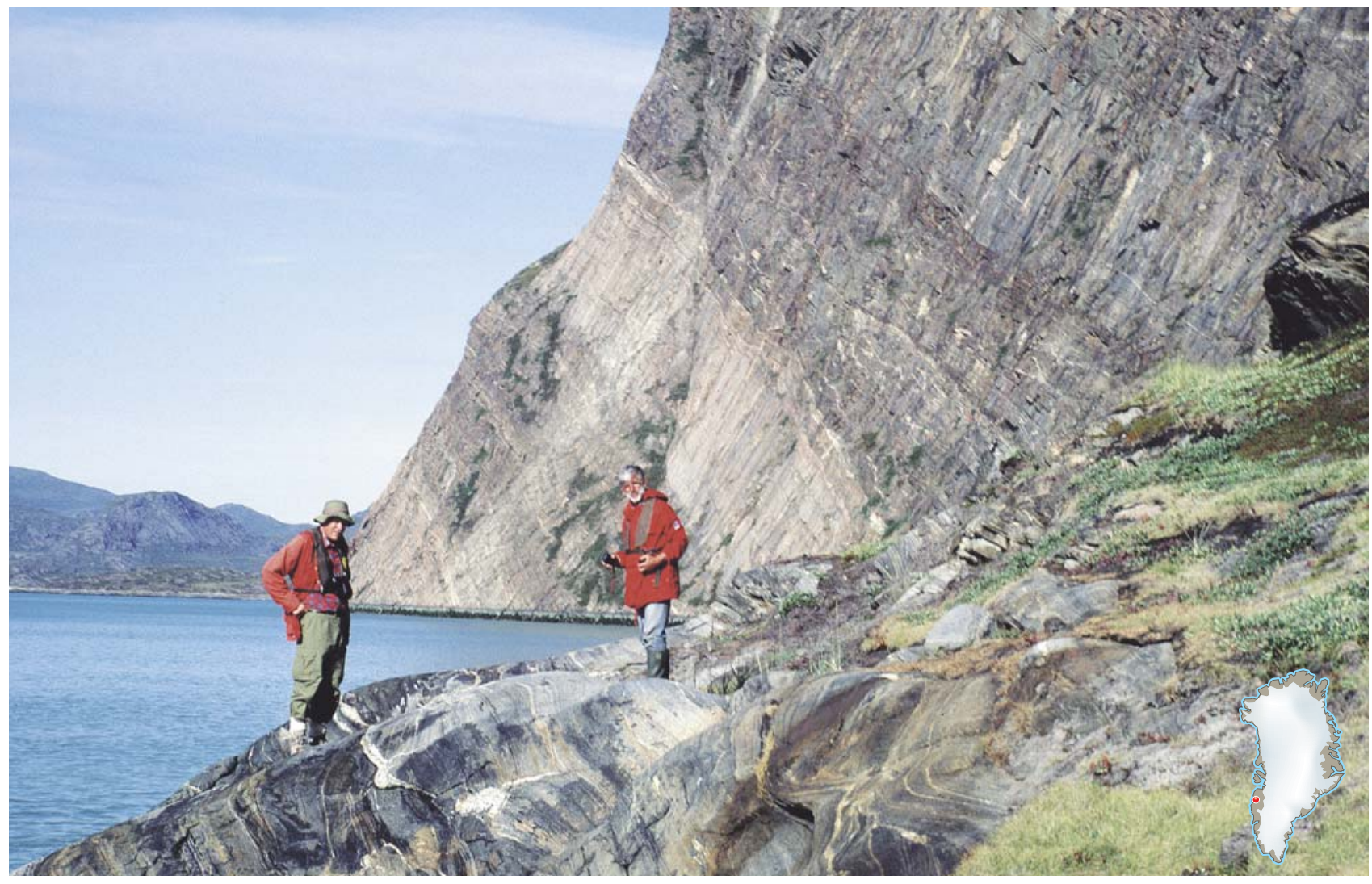

Fig. 10. Nagssugtoqidian orogen. Rock face at south side of inner Nordre Strømfjord/Nassuttooq, southern West Greenland, showing tectonic contact between pale Archaean tonalitic gneisses and overlying dark dioritic gneisses (Arfersiorfik quartz diorite) and supracrustal rocks of Palaeoproterozoic age. Thin slices of marble and calc-silicates occur at the contact and within the Archaean gneisses. The height of section is c. 350 m. Photo: J.A.M. van Gool. 
Palaeoproterozoic in age (c. $1900 \mathrm{Ma}$; Thrane \& Connelly 2006). The involvement of Palaeoproterozoic supracrustal rocks in complex fold structures and shear zones in the central part of the belt shows that the deformation was of Proterozoic age.

\section{Felsic and intermediate intrusions}

Only a few granitic and quartz-dioritic intrusive bodies are shown on the map. Some are Archaean [80], whereas others are of Palaeoproterozoic age [78]. A large sheet of quartz diorite [81], the Arfersiorfik quartz diorite, dated at $1910 \mathrm{Ma}$, occurs close to the border of the Inland Ice at $68^{\circ} \mathrm{N}$ (Henderson 1969; Kalsbeek et al. 1987; K. Sørensen et al. 2006; van Gool \& Marker 2007); it is folded and strongly deformed at its margins, but igneous textures and minerals are preserved in its centre. Strongly deformed Proterozoic quartz-dioritic to tonalitic rocks (not shown on the map) also occur within reworked Archaean gneisses south of the main quartzdiorite body. Together they have been interpreted as remnants of a Palaeoproterozoic arc, tectonically interleaved with the Archaean rocks (Fig. 10; Kalsbeek et al. 1987; van Gool et al. 2002). They range in age from 1920 to $1885 \mathrm{Ma}$ (Connelly et al. 2000).

A large area $(c .30 \times 50 \mathrm{~km})$ east and north-east of Sisimiut/Holsteinsborg is made up of Palaeoproterozoic (1910-1870 Ma) hypersthene gneisses, the Sisimiut intrusive complex (Kalsbeek \& Nutman 1996; Connelly et al. 2000; van Gool et al. 2002). In the field these cannot easily be distinguished from Archaean rocks that occur farther east and, since no age determinations on these rocks were available at the time of map compilation, all the rocks in this area are shown on the map as Archaean, overprinted by Proterozoic granulite facies metamorphism [75].

\section{Nagssugtoqidian orogen in South-East Greenland}

Aeromagnetic data show a continuation of the Nagssugtoqidian orogen from West Greenland beneath the Inland Ice to South-East Greenland (Fig. 11). Here Palaeoproterozoic orogenic activity has been documented from $64^{\circ} 30^{\prime} \mathrm{N}$ to $68^{\circ} \mathrm{N}$ (Fig. 2) on the basis of deformation and high-grade metamorphism, up to eclogite facies, of mafic dykes. This region, centred around the town of Tassilaq/Ammassalik, is dominated by reworked Archaean gneisses $[74,75]$ which were tectonically interleaved with

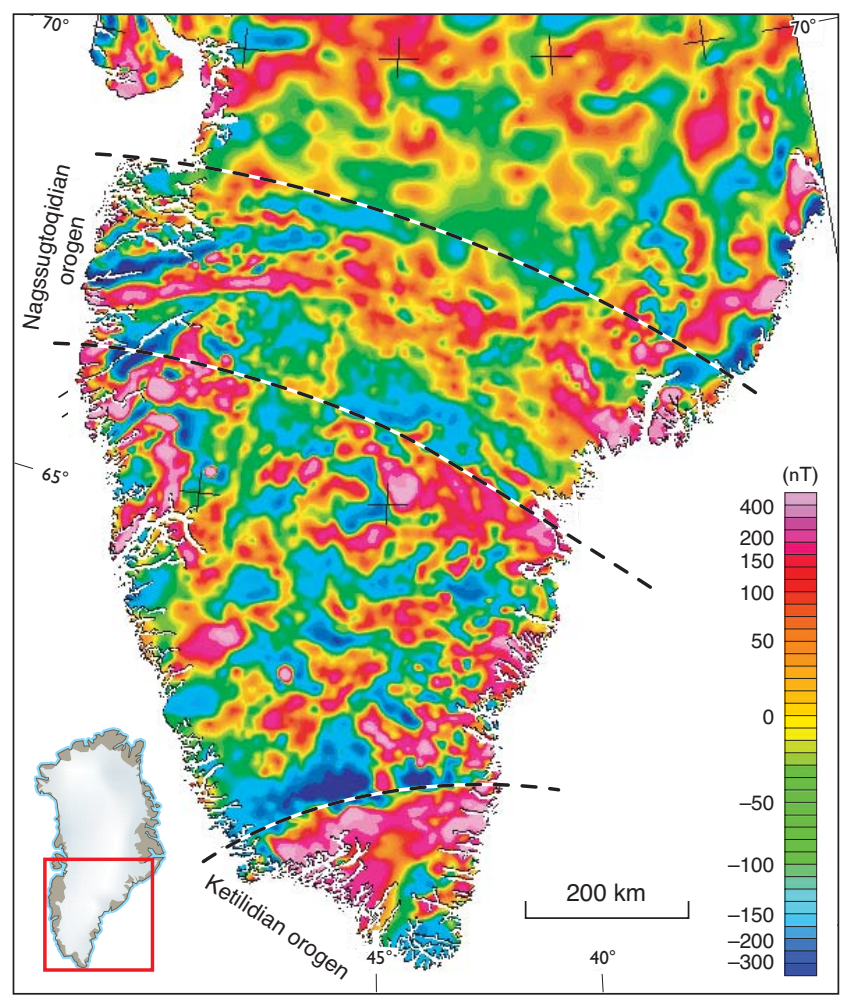

Fig. 11. Aeromagnetic map of southern Greenland showing the continuity of the Nagssugtoqidian orogen from West to South-East Greenland. Data from Verhoef et al. (1996).

metasedimentary rocks during the Palaeoproterozoic (Fig. 12; Chadwick et al. 1989; Kalsbeek 1989). Juvenile Palaeoproterozoic intrusive rocks [81] and post-tectonic (c. $1680 \mathrm{Ma}$ ) granite bodies [78] are also present. Palaeoproterozoic pelitic metasedimentary rocks [67] are common and locally contain abundant kyanite; thick marble units also occur. Archaean anorthositic rocks [85] are present in a few places. A detailed geochronological study of rocks and structures in the Ammassalik region has recently been reported by Nutman et al. (2008b). Before the continuity of the Nagssugtoqidian orogenic belt from West- to South-East Greenland was satisfactorily documented, the latter area was termed the Ammassalik mobile belt (Kalsbeek 1989), but this term should now be abandoned.

\section{Palaeoproterozoic plutonic rocks}

A suite of 1885 Ma leuconoritic and charnockitic intrusive rocks [81], the Ammassalik Intrusive Complex (AIC), occurs as a row of WNW-ESE-trending intrusions at $65^{\circ} 30^{\prime} \mathrm{N}$ in the centre of the East Greenland Nag- 
ssugtoqidian orogen (Friend \& Nutman 1989). It was emplaced into a succession of sedimentary rocks, in which it caused widespread anatexis and produced garnet-rich granitic gneisses [71]. The AIC is interpreted by Nutman et al. (2008b) as a Palaeoproterozoic arc, which was caught between Archaean crustal units during the Nagssugtoqidian collision $c .1870 \mathrm{Ma}$ ago.

Palaeoproterozoic quartz-dioritic to tonalitic intrusions [81] occur locally; one is shown just north of latitude $66^{\circ} \mathrm{N}$ and has been dated at $1900 \mathrm{Ma}$ (Nutman et al. 2008b). Palaeoproterozoic gneisses, formed locally by deformation of such intrusive rocks, are not distinguished on the map.

Scattered post-tectonic granite plutons [78] associated with diorite and local gabbro occur over the central part of the East Greenland Nagssugtoqidian orogen. Their isotopic age is about $1680 \mathrm{Ma}$ (Kalsbeek et al. 1993a), much younger than the peak of tectonic and metamorphic activity in the belt at $c .1870 \mathrm{Ma}$ (Nutman et al. 2008b). Isotopic data show that the granites contain major proportions of crustally derived material (Taylor et al. 1984).

\section{Rinkian fold belt}

The Rinkian fold belt (Henderson \& Pulvertaft 1987; Grocott \& Pulvertaft 1990) lies to the north of the Nagssugtoqidian orogen in West Greenland between latitudes $69^{\circ} 30^{\prime} \mathrm{N}$ and $75^{\circ} \mathrm{N}$ (Fig. 2). North of Nuussuaq it is characterised by the presence of a several kilometres thick Palaeoproterozoic sedimentary succession, the Karrat Group [62], which overlies and is interfolded with reworked Archaean gneisses [74]. It has been difficult in the field to define a distinct boundary between the Nagssugtoqidian and Rinkian belts. However,

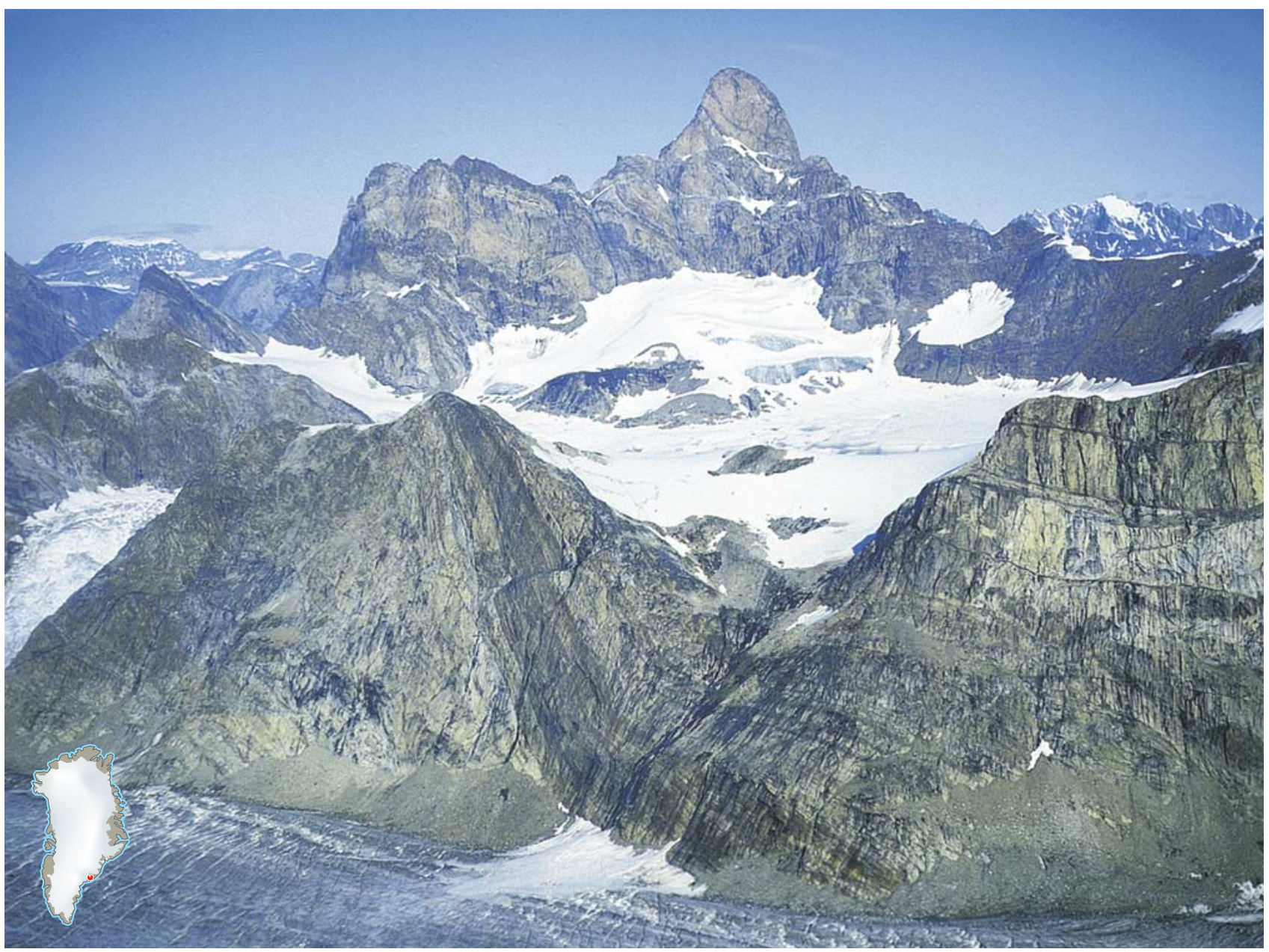

Fig. 12. Nagssugtoqidian orogen in South-East Greenland. Archaean gneisses reworked during the Palaeoproterozoic in granulite and retrograde granulite facies, with supracrustal layers consisting of amphibolite and paragneis. East of northernmost Sermilik $\left(c .66^{\circ} 30^{\prime} \mathrm{N}\right)$, SouthEast Greenland. The prominent summit is $1750 \mathrm{~m}$ high; relief seen is $c .1500 \mathrm{~m}$. Photo: J.C. Escher. 
Connelly \& Thrane (2005) observed a significant change in $\mathrm{Pb}$-isotopic compositions of $\mathrm{K}$-feldspar in granitoid rocks across a high-strain belt at $c .69^{\circ} 30^{\prime} \mathrm{N}$ in Disko Bugt, and suggested that this belt of strong deformation represents the suture between two large crustal blocks. They proposed that the northern, Rinkian block forms part of the Rae craton of northern Canada, and that the southern, Nagssugtoqidian block is the northernmost (deformed) part of the North Atlantic craton (Fig. 3). The areas around Qeqertarsuup Tunua/Disko Bugt and the region north of Nuussuaq are described separately below.

\section{Archaean and Palaeoproterozoic supracrustal rocks: Disko Bugt and Nuussuaq}

The geology of the area around Disko Bugt has been described in detail by Garde \& Steenfelt (1999) and a geological map at 1:250 000 (Garde 1994) is included in their paper. Supracrustal rocks occur throughout the area. Two representative examples: (1) In north-eastern Disko Bugt an arcuate Archaean greenstone belt consists of basic and acid metavolcanic rocks $[68,66]$. The basic rocks, mainly greenschists and meta-pillow lavas, contain a subvolcanic sill complex of gabbros and dolerites [82] (Marshall \& Schønwandt 1999). This belt is intruded by the 2800 Ma Atâ igneous complex (Kalsbeek \& Skjernaa 1999; see below). (2) Another supracrustal belt runs along the south coast of Nuussuaq. In contrast to most other supracrustal units this belt was demonstrably deposited upon older gneisses. It consists of mafic and ultramafic metavolcanic rocks with rhyolites, metasedimentary schists, banded iron formation and minor exhalitive rocks with widespread, but low-grade gold mineralisation. A rhyolite from this belt has yielded an age of c. $2850 \mathrm{Ma}$ (Connelly et al. 2006).

The Archaean rocks of north-eastern Disko Bugt are unconformably overlain by a Palaeoproterozoic sedimentary succession [62], the Anap nunâ Group, which has been correlated with the Karrat Group farther north (see below). The Anap nunâ Group consists of a lower unit of marble and orthoquartzite overlain by thick shallow-water siltstones and sandstones. Although the rocks are folded, Palaeoproterozoic deformation and metamorphism are at a minimum (Garde \& Steenfelt 1999). Parts of the succession have suffered intensive metasomatic albitisation (Kalsbeek 1992).

\section{Gneisses and intrusions: Disko Bugt and Nuussuaq}

Reworked Archaean gneisses [74] in the Disko Bugt region are similar to those of the Nagssugtoqidian orogen. On Nuussuaq they show flat-lying tectonic fabrics and contain anorthosite bodies [85] and dioritic intrusions [82] (Garde \& Steenfelt 1999). North-east of Disko Bugt, 2800 Ma tonalitic rocks of the Atâ intrusive complex [80] hardly show any signs of Archaean or Proterozoic deformation. This complex was emplaced into the arcuate Archaean greenstone belt [68] mentioned above and retains many magmatic features (Kalsbeek \& Skjernaa 1999). New geochronological data for the Disko Bugt region, together with an overview of earlier information, have been presented by Connelly et al. (2006). The oldest age $(3030 \mathrm{Ma})$ was obtained from a dioritic intrusion within amphibolites on south-eastern Nuussuaq.

\section{Palaeoproterozoic supracrustal rocks north of Nuussuaq: the Karrat Group}

The geology of the Rinkian fold belt in the area north of Nuussuaq is depicted on the 1:500 000 Geological map of Greenland, Sheet 4, Upernavik Isfjord (Escher 1985). In this region, the Karrat Group [62] is widely exposed over a $400 \mathrm{~km}$ coastal stretch north of Uummannaq (Fig. 2). It was deposited unconformably on Archaean crystalline basement rocks between $c$. $2000 \mathrm{Ma}$ (U-Pb ages of the youngest detrital zircons; Kalsbeek et al. 1998a) and the emplacement of the Prøven igneous complex [78] at $c$. $1870 \mathrm{Ma}$ (Thrane et al. 2005). The Karrat Group underwent high-grade metamorphism at relatively low pressure at around $1870 \mathrm{Ma}$ (Taylor \& Kalsbeek 1990).

The Karrat Group has been divided into three formations (Henderson \& Pulvertaft 1987). The two lower formations, the Mârmorilik Formation (up to $1.6 \mathrm{~km}$, Garde 1978) and Qeqertarssuaq Formation (more than $2 \mathrm{~km}$, Fig. 13), comprise shelf and rift-type sediments, dominated respectively by marbles and clastic sediments with minor volcanic rocks. These two formations may be correlatives, originally separated by a basement high. At $71^{\circ} 07^{\prime} \mathrm{N}, 51^{\circ} \mathrm{W}$ the Mârmorilik Formation hosted the now exhausted Black Angel lead-zinc mine (Thomassen 1991). Lead-zinc mineralisation has also been observed at other localities in the region.

The upper formation, the Nûkavsak Formation, with a minimum structural thickness of $5 \mathrm{~km}$, is a typical turbidite flysch succession. Extensive tight folding makes estimates of the stratigraphic thickness of the Karrat Group uncertain. Proterozoic sedimentary successions 


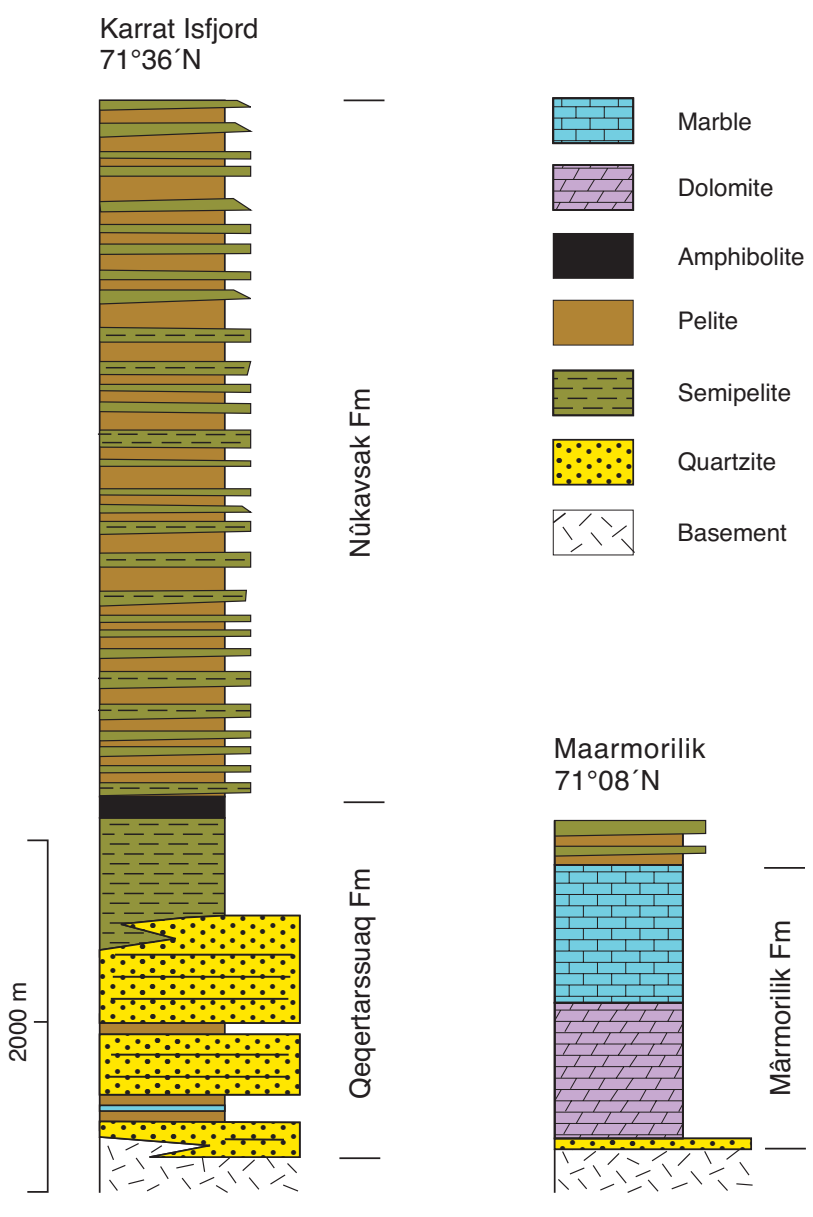

Fig. 13. Schematic lithostratigraphic sections of the Palaeoproterozoic Karrat Group in the Maarmorilik - Karrat Isfjord region. The Nûkavsak Formation consists of a flysch succession of interbedded greywacke and mudstone, now metamorphosed at amphibolite facies. Based on Garde (1978) and Henderson \& Pulvertaft (1987).

similar to the Karrat Group occur in the Foxe fold belt on the western side of Baffin Bugt in north-eastern Canada (the Piling and Penhryn Groups; Henderson $\&$ Tippet 1980; Henderson 1983) suggesting correlation of the Rinkian belt of Greenland and the Foxe fold belt of Canada (see Fig. 3). Connelly et al. (2006) suggest that the Karrat Group was deposited on the passive margin of the Rae craton before collision with the North Atlantic craton.

The Karrat Group and its underlying crystalline basement are complexly interfolded into gneiss-cored fold nappes (Fig. 14; Henderson \& Pulvertaft 1987) which were subsequently refolded into large dome structures. Tectonic interleaving of cover rocks with basement gneisses by thrusting has also taken place so that locally Proterozoic supracrustal rocks occur as enclaves within Archaean gneisses. The extent of this process is exemplified by an isolated occurrence of $\mathrm{Pb}-\mathrm{Zn}$ mineralised marble at $70^{\circ} 30^{\prime} \mathrm{N}, 52^{\circ} 30^{\prime} \mathrm{W}$ in the centre of Nuussuaq (Garde $\&$ Thomassen 1990).

\section{Gneisses and intrusive rocks north of Nuussuaq}

Reworked Archaean gneisses [74] north of Nuussuaq are similar to those elsewhere. Commonly they display flat-lying fabrics related to Palaeoproterozoic thrusting. North of Nuussuaq sheets of Archaean augen gneiss (not distinguished on the map) have been used as structural markers to unravel the complex thrust tectonics of that area (Pulvertaft 1986).

The 1870 Ma Prøven igneous complex [78] (Thrane et al. 2005) in the Upernavik area $\left(c .72^{\circ} 30^{\prime} \mathrm{N}\right)$ consists mainly of charnockitic rocks emplaced into Archaean gneisses and metasedimentary rocks of the Karrat Group, which are here at granulite facies. Samples from the Prøven igneous complex have an A-type geochemical signature, and isotope data indicate that the magma was formed by anatexis of Archaean gneisses and Palaeoproterozoic sedimentary rocks at depth. Melting is suggested to have been induced by upwelling of hot asthenospheric mantle due to delamination of mantle lithosphere following continental collision in the Disko Bugt area (see above).

\section{North-West Greenland and the Inglefield orogenic belt}

The region between $75^{\circ} 15^{\prime}$ and $81^{\circ} \mathrm{N}$ in North-West Greenland is covered by the Geological map of Greenland, Sheet 5, Thule (Dawes 1991, 2006) and Sheet 6, Humboldt Gletscher (Dawes 2004; Dawes \& Garde 2004). The region up to $c .77^{\circ} 30^{\prime} \mathrm{N}$ has not been investigated in detail. It consists mainly of reworked Archaean gneisses [74] with local amphibolites and banded iron formation. The Karrat Group has not been recognised in this region. The c. 2700 Ma Kap York meta-igneous complex [82] at $76^{\circ} \mathrm{N}$ is composed of a suite of plutonic rocks ranging from gabbro to granite, and a major anorthosite complex [85] is exposed at $77^{\circ} 30^{\prime} \mathrm{N}$ (Nutman 1984). An overview of available geochronological information is given in Nutman et al. (2008a).

The area between $c .77^{\circ} 30^{\prime}$ and $79^{\circ} \mathrm{N}$ contains the Palaeoproterozoic Inglefield orogenic belt which mainly consists of high-grade Palaeoproterozoic supracrustal and intrusive rocks that are overlain by Mesoproterozoic sedimentary rocks with basaltic sills, the Thule Supergroup 


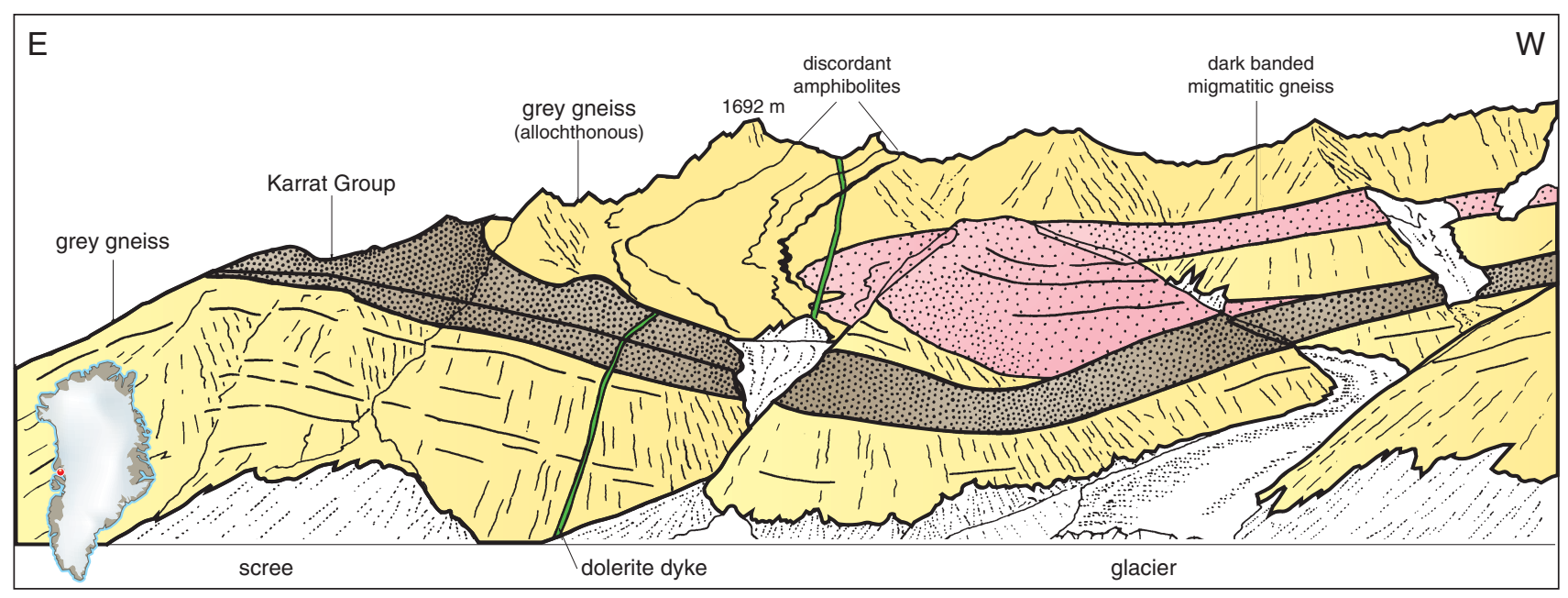

Fig. 14. Sketch of part of one of the characteristic Palaeoproterozoic nappes in the Rinkian fold belt (Kigarsima nappe seen from the north). North side of Upernivik $\varnothing\left(71^{\circ} 20^{\prime} \mathrm{N}\right)$, central West Greenland. Slightly modified from Henderson \& Pulvertaft (1987).

$[3,4,5]$, and by Cambrian deposits $[23,25]$ of the Franklinian Basin. The Inglefield belt is divided into two parts by the E-W-trending Sunrise Pynt Straight Belt (SPSB, not shown on the map) at $c .78^{\circ} 20^{\prime} \mathrm{N}$. Archaean rocks south of the SPSB have been intruded by $c .1980$ Ma tonalites and diorites (Nutman et al. 2008a). The oldest rocks in Inglefield Land, north of the SPSB, are highgrade metasedimentary rocks of the Etah Group. Most of the Group is composed of variably migmatised paragneisses, shown as granulite facies gneisses [71] on the geological map, while better preserved marble-dominated units are shown as supracrustal rocks [67]. Zircon geochronology brackets deposition of the Etah Group between 1980 and $1950 \mathrm{Ma}$ (Nutman et al. 2008a). The Etah Group has been intruded by a variety of metaplutonic rocks (not shown on the map), mainly of intermediate to felsic composition, the Etah meta-igneous complex. Most of these rocks are strongly deformed, but less deformed syenitic and monzonitic rocks are also present, and post-tectonic granites occur locally. Dioritic and granitoid rocks were emplaced during several periods, $c$. 1950-1940 Ma and c. $1920 \mathrm{Ma}$, with high-grade metamorphism around $1920 \mathrm{Ma}$, while late granites have ages of 1780 and $1740 \mathrm{Ma}$ (Nutman et al. 2008a).

$\mathrm{Sm}-\mathrm{Nd}$ isotopic data show that the older intrusive rocks are of juvenile origin, whereas some of the late intrusions were formed by crustal melting (Nutman et al. 2008a). The Inglefield belt is interpreted as a Palaeoproterozoic orogen, formed by collision of Archaean crustal blocks.

\section{Ketilidian orogen}

Orthogneisses cut by dolerite dykes at the southern margin of the Archaean craton are unconformably overlain by Palaeoproterozoic sedimentary rocks [64] and basalts [63]. Towards the south these supracrustal sequences, together with the underlying Archaean gneisses and dykes, are progressively affected by deformation and metamorphism as the Ketilidian orogen (Fig. 3) is approached. The centre of the Ketilidian orogen consists mainly of juvenile Palaeoproterozoic granitic rocks, the Julianehåb batholith $[70,78]$. In the southern part of the orogen high-grade metasedimentary rocks [67] and large intrusions, shown as rapakivi granites [77] on the map, are prominent. The Ketilidian orogen is covered by the Geological Map of Greenland, Sheet 1, Sydgrønland (Allaart 1975; Garde 2007b). During the 1990s the Ketilidian orogen was reinvestigated in more detail. A comprehensive report on this new information has been presented by Garde et al. (2002).

\section{Palaeoproterozoic supracrustal rocks in the northern border zone}

The best preserved Ketilidian supracrustal rocks occur in Grænseland and Midternæs, north-east of Ivittuut, where they are locally almost unmetamorphosed and only superficially deformed (Fig. 15); the age of deposition is not precisely known. The succession has been divided into (1) a lower sedimentary part, the Vallen Group, with $c .1200 \mathrm{~m}$ of shales and greywackes with 


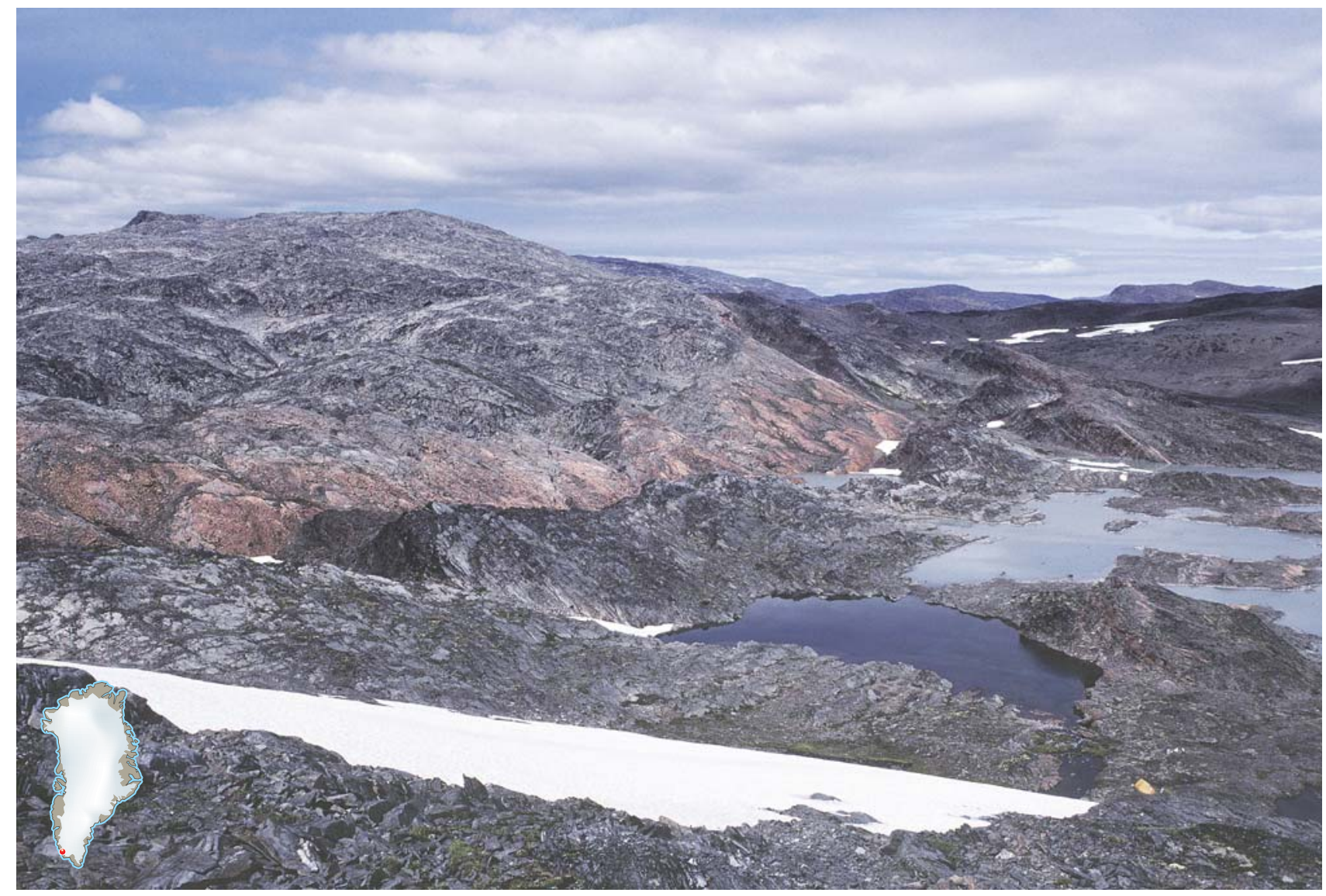

Fig. 15. The basal part of the Ketilidian supracrustal succession in central Grænseland, South-West Greenland, with the Archaean basement in the left background, viewed towards west-north-west. The unconformity forms the red-brown slope in the middle distance, with sporadic sub-Ketilidian regolith and Ketilidian carbonate deposits. The dark layer just above the contact is iron formation. Relief is about $500 \mathrm{~m}$. Orange tent in the right foreground indicates the scale. Photo: A.A. Garde.

subordinate quartzite, conglomerate and carbonate rocks [64], and (2) an upper volcanic part, the Sortis Group [63], which consists mainly of basic pillow lavas and contemporaneous basic sills (Bondesen 1970; Higgins 1970), and has been interpreted to represent ocean floor related to initial rifting. The two groups are in tectonic contact, and it is likely that the Sortis Group was thrust upon the Vallen Group. Southwards these supracrustal rocks become progressively deformed and intruded by Ketilidian granites.

\section{Palaeoproterozoic granitoids and basic- intermediate intrusions, the Julianehåb batholith}

The central part of the Ketilidian orogen is mainly built up of granites, granodiorites and tonalites, commonly with porphyritic textures, collectively known as the Julianehåb batholith ('Julianehåb granite' in older publications). Large parts of the batholith were emplaced between 1868 and $1796 \mathrm{Ma}$ in a sinistral transpressive setting (Chadwick \& Garde 1996; Garde et al. 2002; Pulvertaft 2008). Major shear zones were formed during emplacement of the batholith, giving rise to tectonic fabrics of variable intensity. The most intensely deformed parts of the batholith are shown as gneisses [70] on the geological map, less deformed varieties as foliated and non-foliated granitic rocks [78]. Basic and intermediate intrusions [81] of various ages are also present. These were commonly emplaced simultaneously with felsic magmas, and may occur as mixed rocks in net-veined intrusions. Many of the basic and intermediate plutonic rocks are appinites (see Fig. 20), i.e. they contain hornblende as the main primary mafic mineral (e.g. Pulvertaft 2008). Isotopic data show that the Julianehåb batholith is of juvenile Proterozoic origin (van Breemen et al. 1974; Patchett \& Bridgwater 1984; Kalsbeek \& Taylor 1985; Garde et al. 2002) and does not represent reworked Archaean rocks as previously believed. 


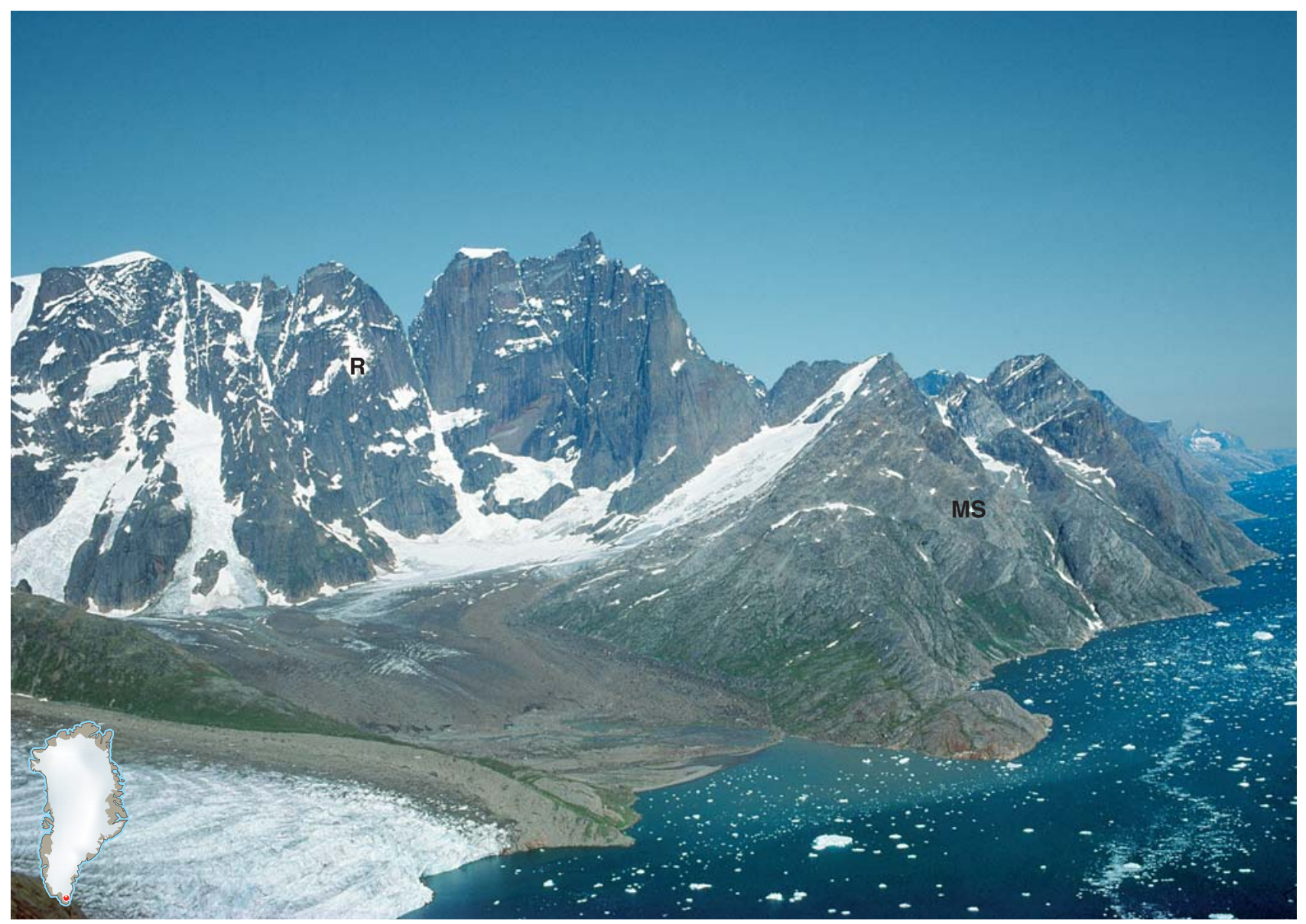

Fig 16. Part of the Ketilidian orogen on the north side of Lindenow Fjord $\left(c .60^{\circ} 30^{\prime} \mathrm{N}\right)$ viewed towards the east. Massive outcrops of a subhorizontal, $c .1740 \mathrm{Ma}$ sheet of the rapakivi suite (R) form the steep cliffs to the north-west (left), above flat-lying metasedimentary rocks (MS) [67]. Highest summits are about 2500 m. Photo: A.A. Garde.

\section{Metasedimentary rocks in the south-eastern part of the Ketilidian orogen}

High-grade supracrustal units [67] are prominent in the south-eastern part of the Ketilidian orogen. They are composed of psammitic and semipelitic gneisses with local marbles and basic metavolcanic rocks. Acid volcanic rocks [65] occur in the inner fjord area north-east of Qaqortoq/Julianehåb $\left(61^{\circ} 30^{\prime} \mathrm{N}\right)$. The clastic sediments are composed mainly of erosion products of the Julianehåb batholith, produced more or less contemporaneously with its emplacement; they are interpreted to represent a fore-arc basin. The rocks underwent highgrade, low-pressure metamorphism, up to granulite facies, and widespread anatexis occurred at $c .1790 \mathrm{Ma}$ (Garde et al. 2002).

\section{The Ketilidian rapakivi suite}

Flat-lying sheets of rapakivi 'granite' [77], folded into kilometre-scale arcs and cusps, are a prominent constituent of the south-easternmost part of the Ketilidian orogen (Fig. 16). The rocks are characterised by mantled Kfeldspar phenocrysts, high $\mathrm{Fe} / \mathrm{Mg}$ ratios and high levels of incompatible elements. Rather than true granites, the suite mainly includes quartz monzonites, quartz syenites, and norites. Isotopic ages between 1720 and $1750 \mathrm{Ma}$ have been obtained from these rocks (Gulson \& Krogh 1975; Garde et al. 2002). 


\section{Archaean-Palaeoproterozoic basement in the East Greenland Caledonian orogen}

The East Greenland Caledonian orogen is built up of fartravelled allochthonous thrust sheets overlying the eastern margin of the Greenland shield. An overview of the geology of the orogen has recently been provided by Higgins et al. (2008), and the region is covered by a new geological map at a scale of 1:1 000000 (Henriksen 2003). Crystalline basement rocks are prominent both within the thrust sheets and the underlying foreland. They were overlain by Neoproterozoic and Palaeozoic sedimentary successions prior to involvement in the Caledonian orogeny (Higgins \& Leslie 2008).

In the Scoresby Sund region, $70-72^{\circ} \mathrm{N}$, Archaean basement gneisses with mafic dykes [74] are prominent. North of $c .72^{\circ} 50^{\prime} \mathrm{N}$ the crystalline basement consists mainly of Palaeoproterozoic orthogneisses [70] (Kalsbeek et al. 1993b). In the border region, $72-73^{\circ} \mathrm{N}$, Palaeoproterozoic granitoid rocks have been intruded into Archaean gneisses (Thrane 2002). An overview over the Precambrian evolution of this region is given by Kalsbeek et al. (2008a).
The Archaean basement complex [74] in the inner Scoresby Sund region and areas immediately to the north, $70^{\circ}-72^{\circ} 50^{\prime} \mathrm{N}$, consists of a variety of migmatitic gneisses (Fig. 17) with scattered foliated granitoid plutonic rocks [80]. In the Charcot Land tectonic window in the northwestern part of the Scoresby Sund region $\left(72^{\circ} \mathrm{N}\right)$ the Archaean basement of the foreland is overlain by a Palaeoproterozoic supracrustal succession [67] consisting of low-grade metasedimentary and metavolcanic rocks (Steck 1971); these are cut by two major postkinematic granodioritic-granitic intrusions [78] emplaced c. 1840 Ma ago (Hansen et al. 1980). Similar rocks [45] occur in the Eleonore $\mathrm{S} \varnothing$ window $\left(c .74^{\circ} \mathrm{N}\right)$, where they are cut by sheets of quartz porphyry, dated at $c .1915 \mathrm{Ma}$ (Kalsbeek et al. 2008).

The basement gneisses in the central and northern parts of the fold belt (north of $74^{\circ} \mathrm{N}$ ), mainly comprise rock units formed c. $2000 \mathrm{Ma}$ ago during a Palaeoproterozoic event of juvenile crust formation. Both older migmatitic gneisses and younger, more homogeneous granites are present. Some of the latter have been dated at $c .1750 \mathrm{Ma}$. Most of the gneisses are at amphibolite

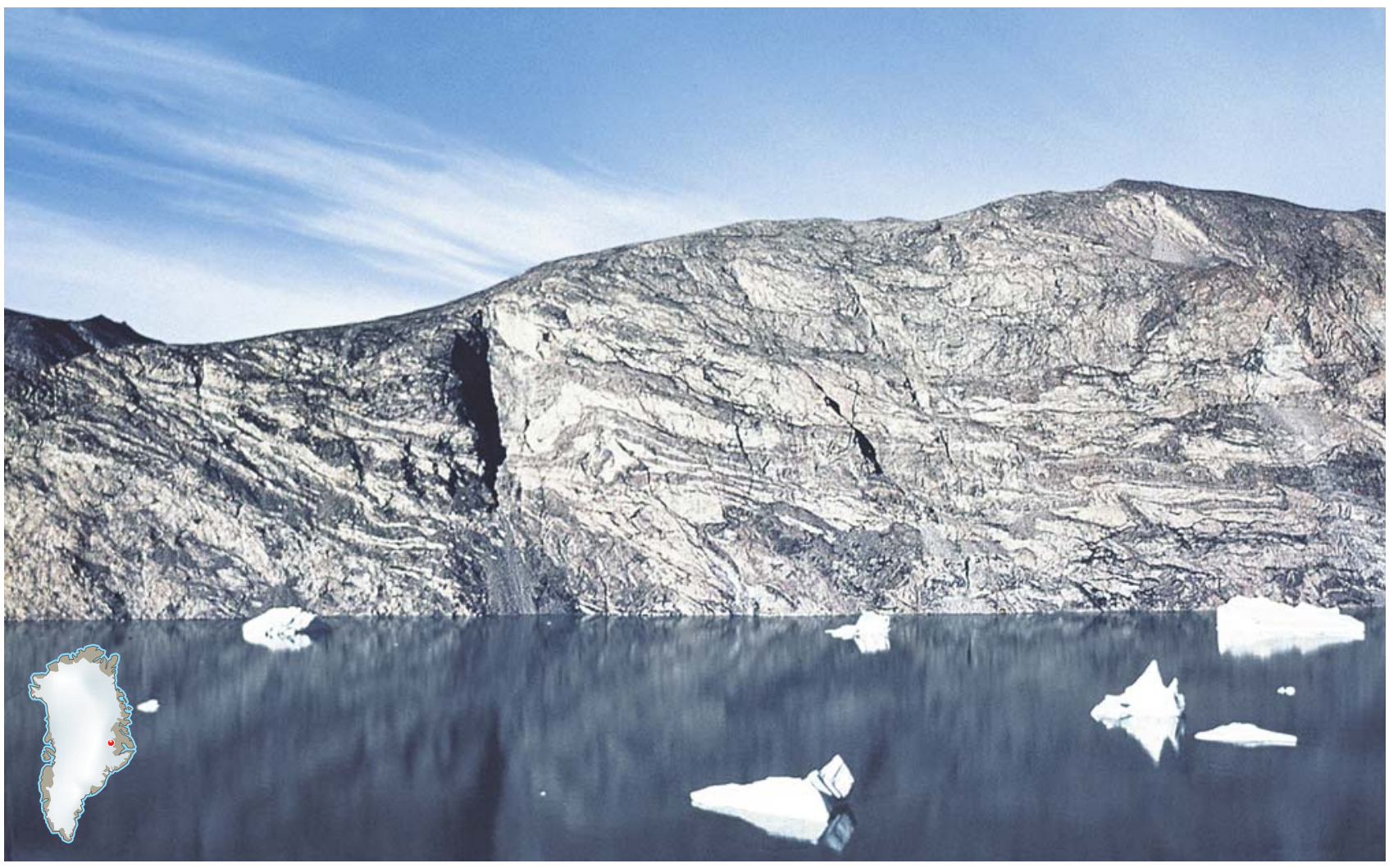

Fig. 17. Crystalline basement within the Caledonian orogen. Archaean gneisses with dark amphibolite layers, affected by Palaeo- and early Neoproterozoic orogenic events, and subsequently reworked during the Caledonian orogeny. South of inner Nordvestfjord/ Kangersik Kiatteq, Scoresby Sund region $\left(71^{\circ} 30^{\prime} \mathrm{N}\right)$, central East Greenland. The profile height is $c .1000 \mathrm{~m}$. 
facies [70], with occasional areas of granulite facies [71]. Large parts of the region underwent Caledonian eclogite facies metamorphism (Gilotti et al. 2008) which, however, is not registered in the gneisses. Supracrustal rocks [67] occur locally. A few isolated intermediate and mafic intrusions [81] occur in the Dove Bugt region $\left(76-78^{\circ} \mathrm{N}\right.$; Hull et al. 1994).

Within this large region of Palaeoproterozoic rocks Archaean orthogneisses [74] have been documented at two localities: at Danmarkshavn $\left(76^{\circ} 40^{\prime} \mathrm{N}\right.$; Steiger et al. $1976)$ and in Payer Land $\left(74^{\circ} 30^{\prime} \mathrm{N}, 23^{\circ} \mathrm{W}\right.$; Elvevold $e t$ al. 2003). The relationships of these Archaean rocks with the surrounding Proterozoic gneisses are uncertain.

\section{Archaean-Palaeoproterozoic basement beneath the Inland Ice}

Little is known about the geology of the area now covered by Greenland's central ice sheet - the Inland Ice
(Dawes 2009b). However, in 1993 a 1.5 m core of bedrock was retrieved from beneath the highest part of the ice sheet $(>3000 \mathrm{~m}$ ) at the GISP 2 ice core locality (Fig. 2; $\left.72^{\circ} 35^{\prime} \mathrm{N}, 38^{\circ} 27^{\prime} \mathrm{W}\right)$. The rock is a leucogranite, and SHRIMP U-Pb zircon data on a few poorly preserved zircons indicate that it is of Archaean origin, but strongly disturbed by one or more subsequent tectonometamorphic events, most likely during the Palaeoproterozoic (A.P. Nutman, personal communication 1995). These results have been confirmed by $\mathrm{Sm}-\mathrm{Nd}, \mathrm{Rb}-\mathrm{Sr}$ and $\mathrm{Pb}$ $\mathrm{Pb}$ isotope data (Weis et al. 1997).

Three samples from ice-transported blocks of granitoid rocks from the area south and south-east of Independence Fjord, North Greenland, have yielded Sm$\mathrm{Nd}$ model ages (DePaolo 1981) of 3.04-3.38 Ga (Kalsbeek \& Frei 2006) and support the view that significant parts of the hidden basement of north-eastern Greenland may consist of Archaean rocks. 


\section{Proterozoic to Phanerozoic geological development after formation of the Precambrian shield}

The Greenland Precambrian shield is mainly composed of crystalline gneisses and plutonic rocks older than 1600 Ma. Younger rock units, Mesoproterozoic to Phanerozoic in age, are in part related to the formation of sedimentary basins and fold belts along the margins of the stable shield. Two major Palaeozoic fold belts - the Ellesmerian fold belt of Ellesmere Island (Canada) and North Greenland and the Caledonian fold belt of East Greenland - developed along the north and east margins of the shield respectively. In the descriptions that follow the onshore Proterozoic to Phanerozoic deposits and orogenic events throughout Greenland are presented chronologically within the framework of major depositional basins.

\section{Palaeo- to Mesoproterozoic unfolded units} Independence Fjord Group, North Greenland

The earliest recorded major depositional basin developed on the Greenland shield is represented by the Independence Fjord Group [31] (Figs 18A, B) which is exposed over large areas of eastern North Greenland and North-East Greenland between north-eastern Peary Land $\left(83^{\circ} \mathrm{N}\right)$ and westernmost Dronning Louise Land $\left(77^{\circ} \mathrm{N}\right)$. The group is more than $2 \mathrm{~km}$ thick, with its base only exposed in western Dronning Louise Land.

The Independence Fjord Group has been studied primarily in the type area around Independence Fjord in North Greenland (see Geological map of Greenland 1:500 000, sheet 8, Peary Land; Bengaard \& Henriksen 1986). It is dominated by alluvial clastic deposits, mainly sandstones that form three 300-900 m thick, laterally correlatable units. These are separated by two laterally extensive, much thinner (4-90 m) silt-dominated units that represent deposition in ephemeral lakes. Deposition of the Independence Group took place in an intracratonic sag basin and the development of extensive lacustrine conditions suggests that sedimentation was controlled by basin-wide changes in subsidence rates (Collinson et al. 2008).

Deposition of the Independence Fjord Group took place between the end of the Palaeoproterozoic orogenic events in northern Greenland at c. $1750 \mathrm{Ma}$ and the intrusion of the Midsommersø Dolerites at $1380 \mathrm{Ma}$ (see below). Rb-Sr dating of clay minerals from siltstones by Larsen \& Graff-Petersen (1980) indicated an age for diagenesis at $c .1380 \mathrm{Ma}$, but the coincidence of this age with the time of emplacement of the Midsommersø Dolerites suggests that this is not the time of sediment deposition. Geochronological data on detrital zircons indicate that most of the detritus that formed the Independence Fjord sandstones was derived from Palaeoproterozoic sources (2000-1800 Ma; Kirkland et al. 2009).

The sandstones and siltstones of the Independence Fjord Group are cut by numerous mafic sheets and sills, the 'Midsommersø Dolerites' (Kalsbeek \& Jepsen 1983; Kalsbeek \& Frei 2006), for which a U-Pb baddeleyite age of $1382 \pm 2$ Ma has been obtained (Upton et al. 2005). The presence of sheets of 'rheopsammite' (intrusive rocks formed by partial melting of sandstone at depth; Jepsen 1971; Kalsbeek \& Frei 2006) witnesses to the intensity of this magmatic event. Although the dolerites form a significant proportion of the outcrop area of the Independence Fjord Group, they are not shown on the present map, but appear on the Geological map of Greenland 1:500 000, Sheet 8, Peary Land, referred to earlier. They are depicted with other important dyke swarms on Fig. 20.

\section{Zig-Zag Dal Basalt Formation, North Greenland}

The Mesoproterozoic Zig-Zag Dal Basalt Formation [30] consists of an up to $1350 \mathrm{~m}$ succession of well-preserved tholeiitic flood basalts. Its main outcrop area is south of Independence Fjord in eastern North Greenland. The Zig-Zag Dal Basalt Formation conformably overlies the Independence Fjord Group and is itself disconformably overlain by the Hagen Fjord Group (Fig. 24). South of Independence Fjord the basalt succession crops out over an area of $10000 \mathrm{~km}^{2}$, but local occurrence of similar basalts in eastern Peary Land indicates that the formation once covered a large part of North Greenland. A close geochemical similarity with the Midsommersø 

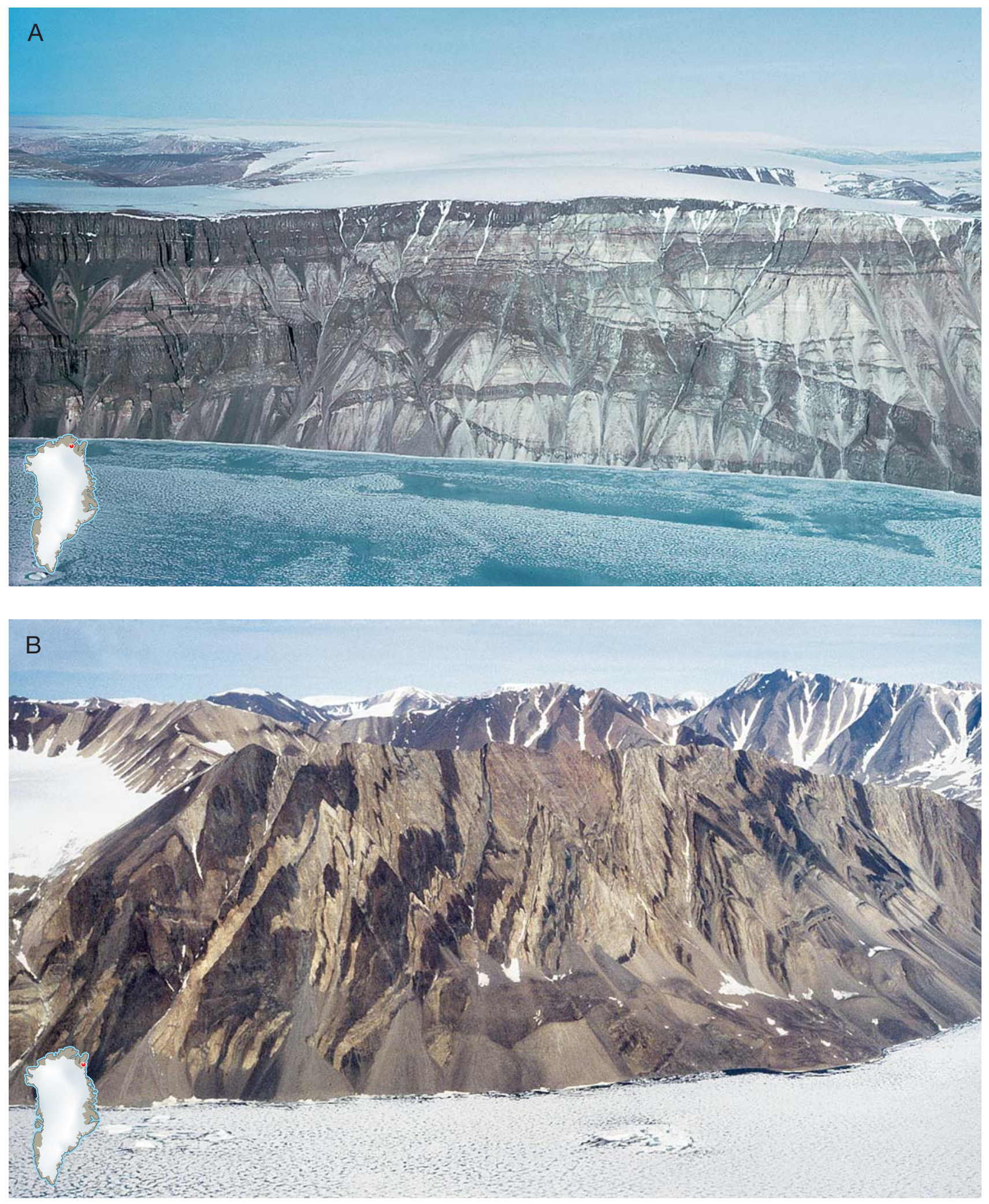

Fig. 18. Palaeoproterozoic Independence Fjord Group sandstones.

A: Undeformed succession on the south side of Independence Fjord cut by $c .1380$ Ma Midsommersø Dolerite intrusions $\left(c .82^{\circ} \mathrm{N}\right)$, eastern North Greenland. Profile height is $c .800 \mathrm{~m}$.

B: Folded and metamorphosed sandstones and dolerite sills within the Caledonian fold belt (see text). North of Ingolf Fjord (c. $\left.80^{\circ} 30^{\prime} \mathrm{N}\right)$, Kronprins Christian Land, eastern North Greenland. Profile height is $c .1000 \mathrm{~m}$. 
Dolerites implies that the basalts are related to the same igneous event that produced the dolerites, and an age of c. $1380 \mathrm{Ma}$ for the basalts is therefore indicated.

The Zig-Zag Dal Basalt Formation is divided into three main units. A 'Basal Unit' of thin aphyric basalt flows is $100-200 \mathrm{~m}$ thick and includes pillow lavas in its lower part. The overlying 'Aphyric Unit' (c. $400 \mathrm{~m}$ ) and the uppermost 'Porphyritic Unit' (up to $750 \mathrm{~m}$ ) together comprise 30 flows of mainly subaerial lavas. The present distribution pattern of the flows shows a maximum thickness of the succession in the area south of Independence Fjord, implying subsidence of this central region during the extrusion of the basalts and prior to the peneplanation which preceded deposition of the Hagen Fjord Group.

Detailed investigations of the basalts have been carried out by Kalsbeek \& Jepsen (1984) and Upton et al. (2005). Based on trace element and isotope data the latter authors conclude that magma generation took place in an upwelling mantle plume underneath an attenuating continental lithosphere. The lavas of the Porphyritic Unit are considered to represent essentially uncontaminated plume-source melts.

\section{Correlation with similar rocks in the northernmost part of the East Greenland Caledonides}

Sandstones and conglomerates interpreted as strongly deformed representatives of the Independence Fjord Group [31] are found within the northernmost parts of the Caledonian fold belt in Kronprins Christian Land and areas to the south (Geological map of Greenland
1:500 000, Sheet 9, Lambert Land, Jepsen 2000; Pedersen et al. 2002; Collinson et al. 2008). As in the North Greenland platform, they are cut by numerous sheets of dolerite (Fig. 18B). Basaltic and andesitic lavas in this area are shown on the map as Zig-Zag Dal Basalt Formation [30], but SHRIMP U-Pb dating has yielded an age of $1740 \mathrm{Ma}$ for associated rhyolitic rocks (Kalsbeek et al. 1999), and correlation with the $1380 \mathrm{Ma}$ Zig-Zag Dal Basalt Formation is therefore excluded. The sandstones and conglomerates in Kronprins Christian Land are interbedded with the lavas, and an age of $c .1740 \mathrm{Ma}$ is therefore indicated. This age is similar to that of the youngest granites within the crystalline basement in the Caledonian fold belt (see p. 31), and the sedimentary rocks can be regarded as molasse-type deposits related to the breakdown of the Palaeoproterozoic orogen in North-East Greenland. If a correlation with the Independence Fjord Group in the platform is assumed, the sandstones and conglomerates in Kronprins Christian Land must represent the lowermost part of that group.

\section{Gardar Province, South Greenland}

The Mesoproterozoic Gardar Province (Upton \& Emeleus 1987; Kalsbeek et al. 1990; Upton et al. 2003) is characterised by faulting, deposition of sediments and volcanic rocks, and alkaline igneous activity. An approximately $3400 \mathrm{~m}$ thick succession of sandstones and lavas referred to as the Eriksfjord Formation (Poulsen 1964) accumulated within an ENE-WSW-trending continental rift, preserved at about $61^{\circ} \mathrm{N}$. Within and outside the rift, major central intrusions and numerous dykes were emplaced (see also dyke map Fig. 20). An intrusive com-

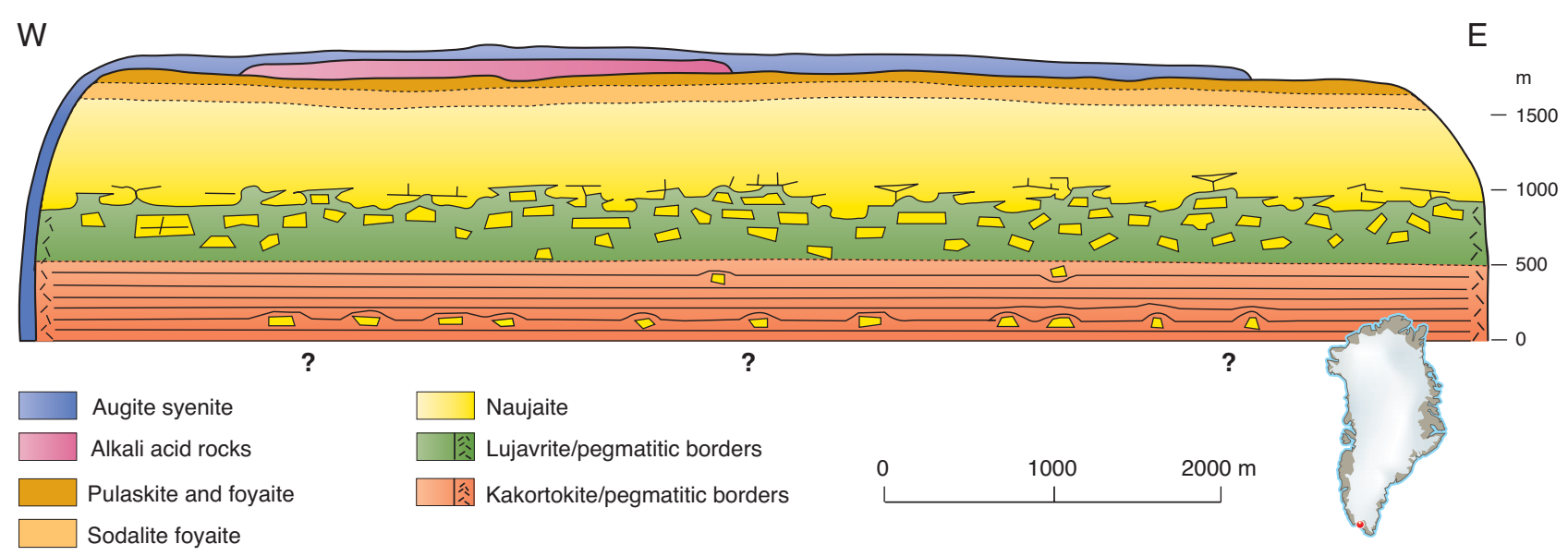

Fig. 19. Diagrammatic cross-section of the Ilímaussaq intrusion, Gardar Province, west of Narsaq in South Greenland. The intrusion has an outcrop area of $17 \times 8 \mathrm{~km}$ and has been dated at $1143 \pm 21 \mathrm{Ma}$ (see review by Kalsbeek et al. 1990; H. Sørensen 2006a). Slightly modified from Andersen et al. (1981). 


\section{Dykes in Greenland}

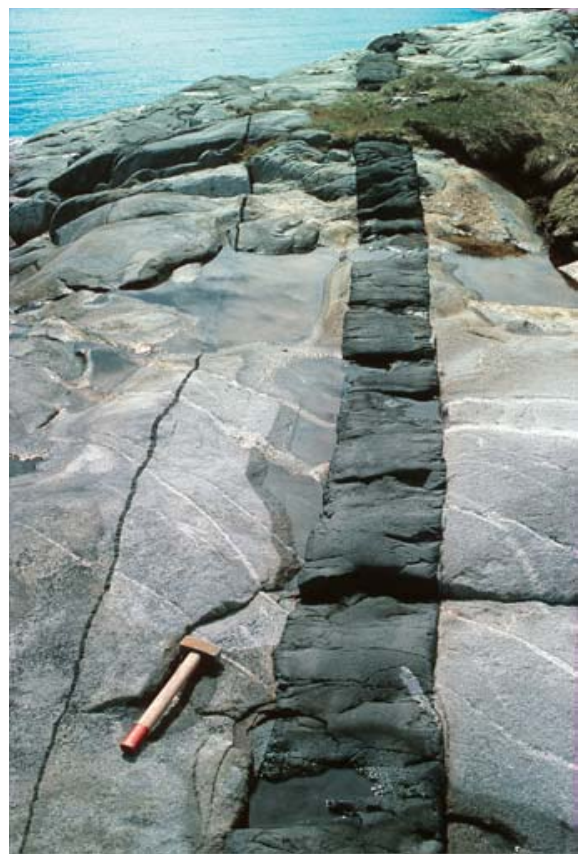

Undeformed Proterozoic dolerite dyke belonging to the 'MD' dyke swarm, cutting Archaean orthogneisses, northern Fiskefjord region, southern West Greenland. Photo: A.A. Garde.

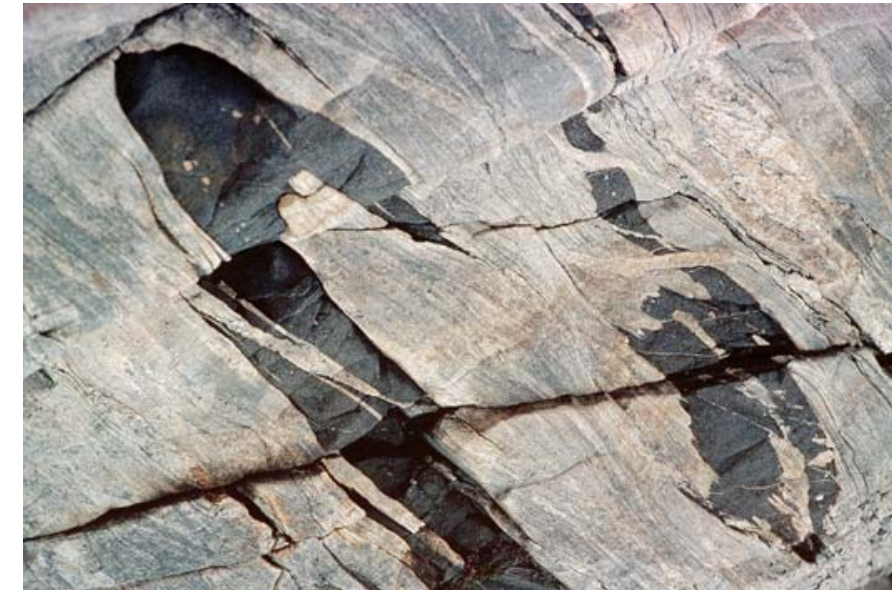

Deformed and fragmented Archaean Ameralik metabasic dyke cutting Eoarchaean 'Amîtsoq' gneisses, Godthåbsfjord region, southern West Greenland. Width of view c. 1.5 m. Photo: A.A. Garde.

There are few areas in Greenland where the rocks are not cut by mafic dykes. The dykes range in age from Palaeoarchaean in the Godthåbsfjord area to Cenozoic in parts of North, East and West Greenland.

It is very difficult to date mafic dykes, especially where they have been deformed and metamorphosed, and early $\mathrm{K}-\mathrm{Ar}$ and $\mathrm{Rb}-\mathrm{Sr}$ age determinations have proved to be imprecise and sometimes entirely misleading. In many cases the age of the dykes is therefore imperfectly known. Moreover, in cases where precise age determinations have been carried out, results show that dykes previously believed to belong to a single swarm may have significantly different ages. The diagrams on the opposite page illustrate the history of dyke emplacement in Greenland, based on the best age estimates available at present.

Among the best known dyke swarms in Greenland are the Ameralik dykes in the Godthåbsfjord area, which were intruded into Eoarchaean gneisses, but are cut by Meso- and Neoarchaean granitoid rocks; this permits distinction between Eoarchaean and Meso- and Neoarchaean lithologies. The Kangâmiut dykes in West Greenland are well preserved in the Archaean craton, but deformed and metamorphosed in the Palaeoproterozoic Nagssugtoqidian orogen to the north; this makes it possible to monitor the influence of Nagssugtoqidian metamorphism and deformation on the host rocks.

\begin{tabular}{ll|l|l|} 
Legend & $\begin{array}{l}\text { with one trend } \\
\text { direction }\end{array}$ & \multicolumn{1}{c}{$\begin{array}{l}\text { with two or } \\
\text { more trends }\end{array}$} & \multicolumn{1}{c}{$\begin{array}{l}\text { deformed and } \\
\text { metamorphosed }\end{array}$} \\
\cline { 2 - 4 } $\begin{array}{l}\text { Dolerites and associated dykes } \\
\text { Kimberlites, lamproites and } \\
\text { lamprophyric dykes }\end{array}$ & & & \\
\cline { 2 - 4 } & & & \\
\cline { 2 - 4 }
\end{tabular}

Fig. 20 (above and facing pages): Diagrammatic representation of the major suites of mafic dykes and sills in Greenland. Compiled by J.C. Escher and F. Kalsbeek 1997. 


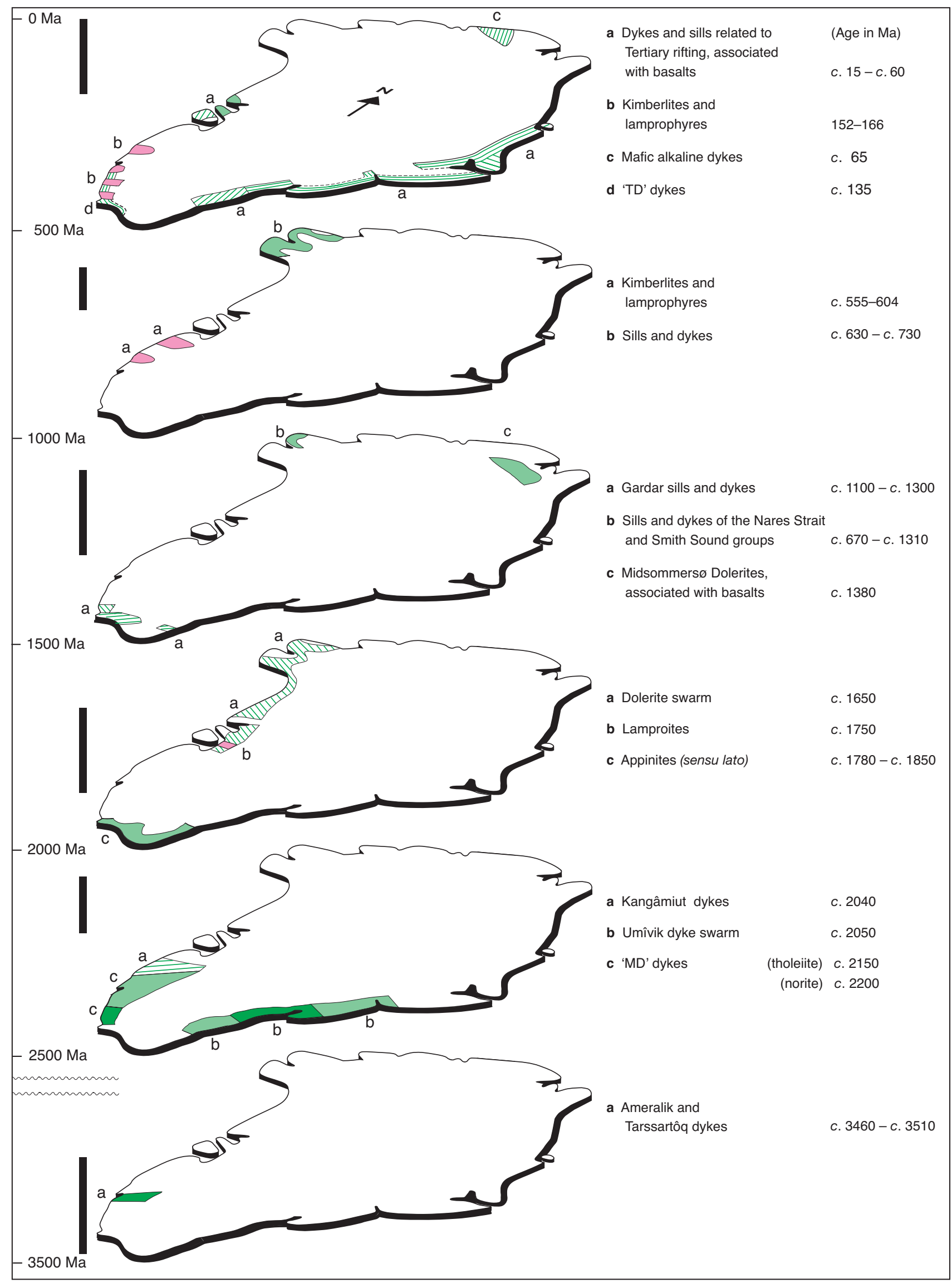


plex at the head of Danell Fjord (c. $\left.60^{\circ} 50^{\prime} \mathrm{N}, 43^{\circ} 30^{\prime} \mathrm{W}\right)$ in South-East Greenland is indicated on the map as Ketilidian rapakivi granite [77], but later radiometric dating has yielded a Gardar age (Garde et al. 2002).

The sedimentary [12] and volcanic rocks [11] of the Eriksfjord Formation rest uncomformably on Ketilidian granites. The Eriksfjord Formation comprises $c .1800 \mathrm{~m}$ of sedimentary strata and $1600 \mathrm{~m}$ of volcanic rocks. The sedimentary rocks, mainly found in the lower part of the succession, are fluvial and aeolian arkosic to quartzitic sandstones and conglomerates (Clemmensen 1988; Tirsgaard \& Øxnevad 1998). The volcanic rocks are dominated by basaltic lavas, with subordinate trachytes and phonolites in the upper part and a carbonatite complex in the lower part (Stewart 1970; Larsen 1977; Upton \& Emeleus 1987). The age of the Eriksfjord Formation is $c .1170-1200 \mathrm{Ma}$ (Paslick et al. 1993).

The Gardar intrusive complexes [56] range in age from $c .1300$ to $c .1120 \mathrm{Ma}$ and have been divided into three age groups (Upton \& Emeleus 1987; Upton et al. 2003). They comprise central ring intrusions, complexes with several individual intrusive centres, and giant dykes (Emeleus \& Upton 1976; Upton \& Emeleus 1987). Petrologically, the intrusive complexes are dominated by differentiated salic rocks including syenites, nepheline syenites, quartz syenites, and granites (Fig. 19); mildly alkaline gabbros and syenogabbros are subordinate but are dominant in the giant dykes. The intrusions were emplaced in the middle part of the Gardar rift as well as in the areas to the north-west and south-east. Major swarms of basic dykes of Gardar age occur throughout South and South-West Greenland (see dyke map, Fig. 20).

\section{Early Neoproterozic orogenic units reworked in the East Greenland Caledonian fold belt}

A suite of early Neoproterozoic augen granites and leucogranites [55] is widely distributed within the Krummedal supracustal sequence of the high-grade uppermost Caledonian (Hagar Bjerg) thrust sheet between Scoresby Sund $\left(70^{\circ} \mathrm{N}\right)$ and about $74^{\circ} \mathrm{N}$; the granitoids have yielded protolith ages of 940-910 Ma (Jepsen \& Kalsbeek 1998; Kalsbeek et al. 2000; Watt \& Thrane 2001). These magmatic events are contemporaneous with high-grade metamorphism dated in overgrowth rims on detrital zircons (Kalsbeek et al. 2000; Watt et al. 2000; Watt \& Thrane 2001), as well as ductile deformation that, at least locally, produced nappe-scale recumbent folds in the reworked migmatite and paragneiss complex [52].
A comparable scenario is recorded in eastern Svalbard where 970-940 Ma events are recorded and augen granites have been emplaced synchronously with deformation (Johansson et al. 2000); in Scotland zircon geochronology has revealed a range of tectonothermal events from 840-730 Ma (Leslie et al. 2008).

\section{Supracrustal rocks}

The Krummedal supracrustal sequence [46] consists of a $2500-8000 \mathrm{~m}$ thick suite of pelitic, semipelitic and quartzitic rocks generally metamorphosed at amphibolite facies (Henriksen \& Higgins 1969; Higgins 1974 , 1988; Higgins \& Leslie 2008; Figs 21, 22). Lateral and vertical lithological variations are considerable and correlation between the various local successions has not been possible. Contacts with the underlying Archaean [74] and Palaeoproterozoic gneisses [70] are generally

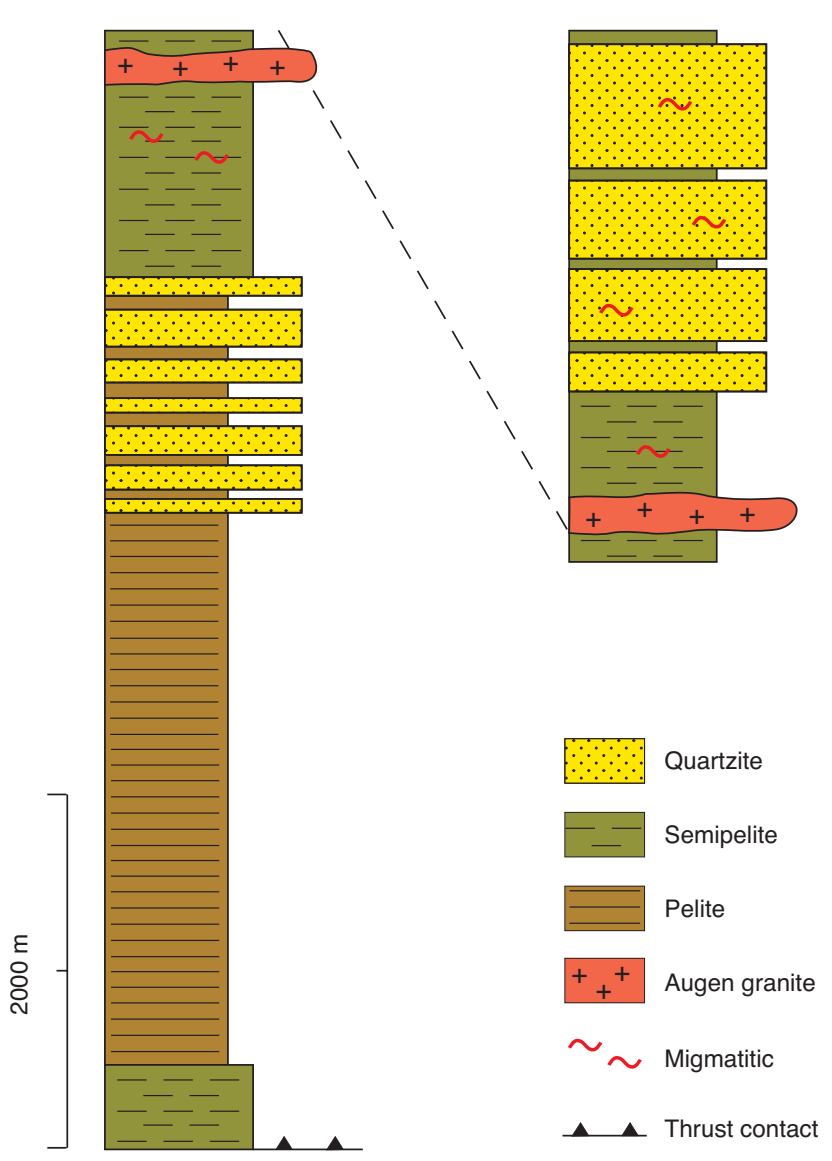

Fig. 21. Sections of the Mesoproterozoic Krummedal supracrustal sequence, north of inner Nordvestfjord/Kangersik Kiatteq $\left(71^{\circ} 30^{\prime} \mathrm{N}\right)$, Scoresby Sund region, central East Greenland. Based on Higgins (1974). 
Fig. 22. Krummedal supracrustal sequence comprising rusty garnetiferous gneissic schists and siliceous paragneisses, inner Nordvestfjord/ Kangersik Kiatteq $\left(71^{\circ} 30^{\prime} \mathrm{N}\right)$, Scoresby Sund region, central East Greenland. Profile height is $c .1500 \mathrm{~m}$.

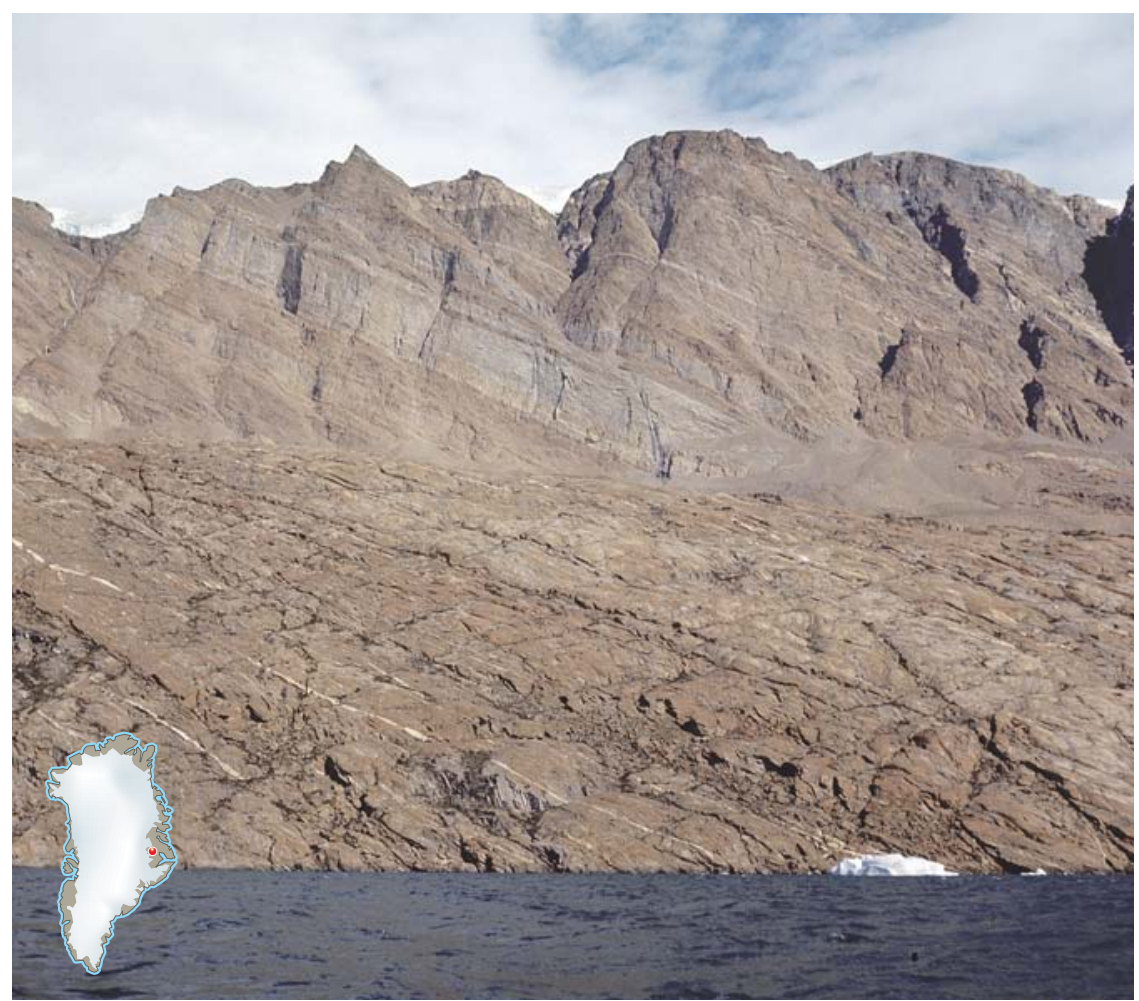

conformable, but rare discordances may reflect preservation of an original unconformity (Higgins et al. 1981). The 'Smallefjord sequence' [46] that crops out between Grandjean Fjord $\left(75^{\circ} \mathrm{N}\right)$ and Bessel Fjord $\left(76^{\circ} \mathrm{N}\right)$ (Friderichsen et al. 1994) is comparable in lithology and development to the Krummedal succession. Age determinations on zircons suggest deposition of both sequences later than $c .1100 \mathrm{Ma}$, and high-grade metamorphism during an early Neoproterozoic event at c. $950 \mathrm{Ma}$ (Strachan et al. 1995; Kalsbeek et al. 1998b). The Krummedal sequence of the lowermost Caledonian (Niggli Spids) thrust sheet appears to lack the early Neoproterozoic granitoids and migmatitic developments recorded in similar rocks within the uppermost (Hagar Bjerg) thrust sheet (see later).

\section{Migmatites and granites}

The Krummedal supracrustal sequence of the uppermost Hagar Bjerg thrust sheet in the southern part of the East Greenland Caledonian fold belt has been intensely migmatised and transformed into paragneiss [52], and as noted above, has been intruded by sheets of augen granites up to $1000 \mathrm{~m}$ thick as well as other granite bodies [55] (Steiger et al. 1979). In the Scoresby Sund region these rock units have been deformed into major recum- bent folds (Leslie \& Nutman 2003). A second generation of Caledonian granite intrusions [54] was produced by partial melting of the Krummedal supracrustal sequence, and some of these granites migrated upwards into the overlying Eleonore Bay Supergroup [44].

\section{Mesoproterozoic - early Neoprotero- zoic sedimentary basin in North-West Greenland and Ellesmere Island} Thule Supergroup

The Thule basin is defined by a thick undeformed sedimentary-volcanic succession - the Thule Supergroup that straddles northern Baffin Bugt and Smith Sund (Dawes et al. 1982; Dawes 1997, 2004, 2006). The eastern and western parts of the basin are exposed in NorthWest Greenland and south-eastern Ellesmere Island (Canada), with extensive sections offshore (Funck et al. 2006). As such, the Thule Basin is one of several MesoNeoproterozoic intracratonic depocentres fringing the northern margin of the Canadian-Greenland shield. In Greenland, the rocks are widely exposed between Inglefield Land $\left(79^{\circ} \mathrm{N}\right)$ and Thule Air Base/Pituffik $\left(76^{\circ} \mathrm{N}\right)$.

The Thule Supergroup has a cumulative thickness of at least $6 \mathrm{~km}$ and comprises continental to shallow marine sedimentary rocks, basaltic rocks and a conspicuous num- 

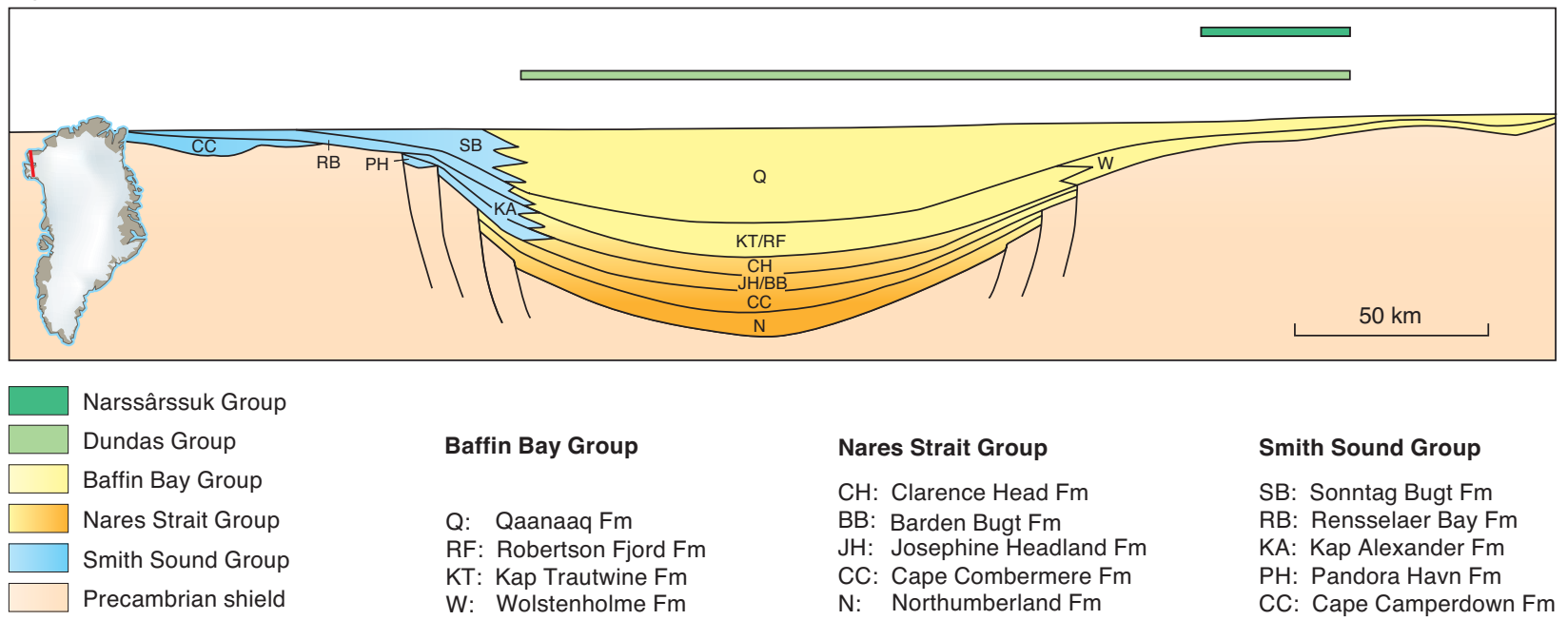

Smith Sound Group

SB: Sonntag Bugt Fm RB: Rensselaer Bay Fm KA: Kap Alexander Fm $\mathrm{PH}$ : Pandora Havn Fm CC: Cape Camperdown Fm

Fig. 23. Cross-section through the Thule Basin, North-West Greenland, with the lower Thule Supergroup as basin fill, showing the relationships of groups and their formations. The spatial relationship of the Dundas and Narssârssuk Groups superimposed on this Mesoproterozoic evolutionary stage is shown by the green bars. Vertical exaggeration $\times 25$. Slightly modified from Dawes (1997).

ber of doleritic sills. Resting with a profound unconformity on the peneplained Archaean-Palaeoproterozoic crystalline shield, the basin developed between $c .1270$ $\mathrm{Ma}$ and around $900 \mathrm{Ma}$ ago (for discussion, see Dawes 1997, 2006; Samuelsson et al. 1999). It is dissected by a half-graben system dominated by WNW-ESE-trending faults.

The Thule Supergroup is divided into a lower part of three groups [5] and an upper part of two [3, 4]. All of the groups contain red beds. When the map was compiled, a Middle - Late Proterozoic age was assigned (Dawes \& Vidal 1985; Dawes \& Rex 1986), but reappraisal of the acritarch fauna suggests a middle Mesoproterozoic to early Neoproterozoic age for the entire succession (Samuelsson et al. 1999; Dawes 2006). The lower part comprises: (1) the Smith Sound Group of mainly shallow marine sandstones and multicoloured shales with stromatolitic carbonates; (2) the Nares Strait Group which at its base consists of inner shelf mudstones and fluvial sandstones, succeeded by terrestrial basaltic extrusive rocks and volcaniclastic red beds overlain by stromatolitic carbonate and shales topped by shallow marine sandstones; (3) the Baffin Bay Group of multicoloured sandstones and conglomerates with intervals of shale-siltstone, mainly of mixed continental to shoreline origin. The upper part of the Thule Supergroup comprises: (4) the Dundas Group [4] of deltaic to coastal plain deposits, dominated by dark shales, siltstones and finegrained sandstones with thin carbonate-rich beds, and
(5) the Narssârssuk Group [3], representing deposition in a low-energy environment, with a cyclic carbonate and red-bed siliciclastic succession. The latter comprises interbedded dolomite, limestone, sandstone, siltstone and shale with evaporites. The Narssârssuk Group, the youngest unit, has a very restricted occurrence in a half-graben on the south-eastern margin of the Thule Basin (Fig. 23).

\section{Neoproterozoic sedimentary basins in North, North-East and East Greenland Hagen Fjord Group, North Greenland}

Neoproterozoic basin deposits laid down between 800 and $590 \mathrm{Ma}$ ago occur extensively in eastern North Greenland, where they crop out over an area of $10000 \mathrm{~km}^{2}$ west of Danmark Fjord. These deposits, assigned to the Hagen Fjord Group (Figs 24, 25), overlie sandstones of the Palaeoproterozoic Independence Fjord Group and basalts of the Mesoproterozoic Zig-Zag Dal Basalt Formation together with their $(1380 \mathrm{Ma})$ correlatives the Midsommersø dolerite intrusions (Sønderholm \& Jepsen 1991; Clemmensen \& Jepsen 1992; Sønderholm et al. 2008). The easternmost occurrences of the succession are represented in the Caledonian Vandredalen thrust sheet in Kronprins Christian Land that has a demonstrable westward displacement of $35-40 \mathrm{~km}$ (Higgins et al. 2001a, b, 2004b; Leslie \& Higgins 2008). 


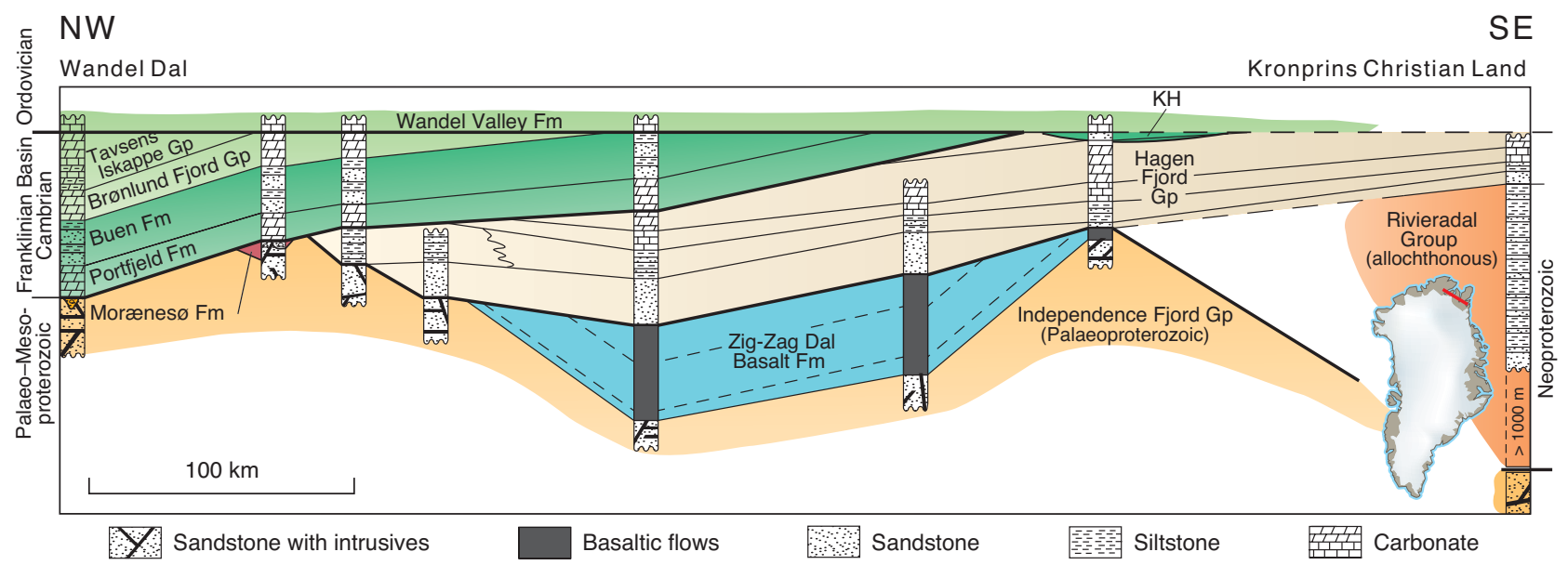

Fig. 24. Schematic cross-section of the Proterozoic-Ordovician succession in eastern North Greenland between Wandel Dal $\left(c .82^{\circ} \mathrm{N}\right)$ and Kronprins Christian Land $\left(c .80^{\circ} \mathrm{N}\right)$. The cross-section shows the relationships between the Mesoproterozoic Zig-Zag Dal Basalt Formation, the Neoproterozoic Hagen Fjord Group with correlatives, and the underlying and overlying sequences. Colours correspond to those used on the map. Bold lines represent erosional unconformities. Slightly modified from Clemmensen \& Jepsen (1992). KH, Kap Holbæk Formation.

The Hagen Fjord Group [27] has a maximum thickness of 1000-1100 m and comprises a succession of siliciclastic and carbonate sedimentary rocks deposited on a shallow-water shelf. Its lower part mainly comprises sandstones which are overlain by a sandstone-siltstone association. The upper part is characterised by limestones and dolomites with abundant stromatolites (Fyns Sø Formation). The overlying sandstone unit (Kap Holbæk Formation) is now known to be early Cambrian, and is excluded from the Hagen Fjord Group (Smith et al. 2004). The age of the Hagen Fjord Group is poorly constrained, but a pre-600 Ma age is now suggested (Sønderholm et al. 2008).

The Rivieradal sandstones [29], now the Rivieradal Group (Smith et al. 2004), are confined to the allochthonous, Caledonian, Vandredalen thrust sheet in the Kronprins Christian Land area, and are interpreted as deepmarine deposits equivalent in age to the lower part of the Hagen Fjord Group (Clemmensen \& Jepsen 1992; Sønderholm et al. 2008). This succession is 7500 to $10000 \mathrm{~m}$ thick and comprises conglomerates, sandstones, turbiditic sandstones and mudstones that accumulated in a major east-facing half-graben basin; the bounding western fault was reactivated as a thrust during the Caledonian orogeny (Higgins et al. 2001b).

A succession of diamictites and sandstones up to $200 \mathrm{~m}$ thick, believed to be late Precambrian (Marinoan, c. $635 \mathrm{Ma}$ ) in age, forms isolated small outcrops in eastern North Greenland; these are known as the Morænesø Formation [28]. The formation is not included in the redefined Hagen Fjord Group of Clemmensen \& Jepsen
(1992) but is in part equivalent or slightly younger in age (Collinson et al. 1989; Sønderholm \& Jepsen 1991; Smith \& Rasmussen 2008).

\section{Eleonore Bay Supergroup, East and North-East Greenland}

The Eleonore Bay Supergroup comprises a more than $14 \mathrm{~km}$ thick succession of shallow-water sedimentary rocks which accumulated in a major sedimentary basin exposed between latitudes $71^{\circ} 40^{\prime}$ and $76^{\circ} \mathrm{N}$ in East and North-East Greenland (Sønderholm \& Tirsgaard 1993; Sønderholm et al. 2008). Exposures only occur within the present Caledonian fold belt, and in general the sedimentary rocks are moderately deformed and weakly to moderately metamorphosed. The nature of the lower contact of the Eleonore Bay Supergroup has been widely debated. The oldest sedimentary rocks are in contact with the Krummedal supracrustal succession, with the contact described in some areas as an extensional detachment (Hartz \& Andresen 1995; Andresen et al. 1998; White et al. 2002), and in other areas as a westward directed thrust (Higgins \& Leslie 2008; Leslie \& Higgins 2008). Relationships are complicated by extensive anatexis and the presence of Caledonian granites. Sedimentation is constrained to the interval between $c .900 \mathrm{Ma}$ and c. $665 \mathrm{Ma}$ by the youngest ages on detrital zircons from the lowest levels of the Eleonore Bay Supergroup and the Marinoan (c. $635 \mathrm{Ma})$ age of the overlying Tillite Group (Sønderholm et al. 2008). 


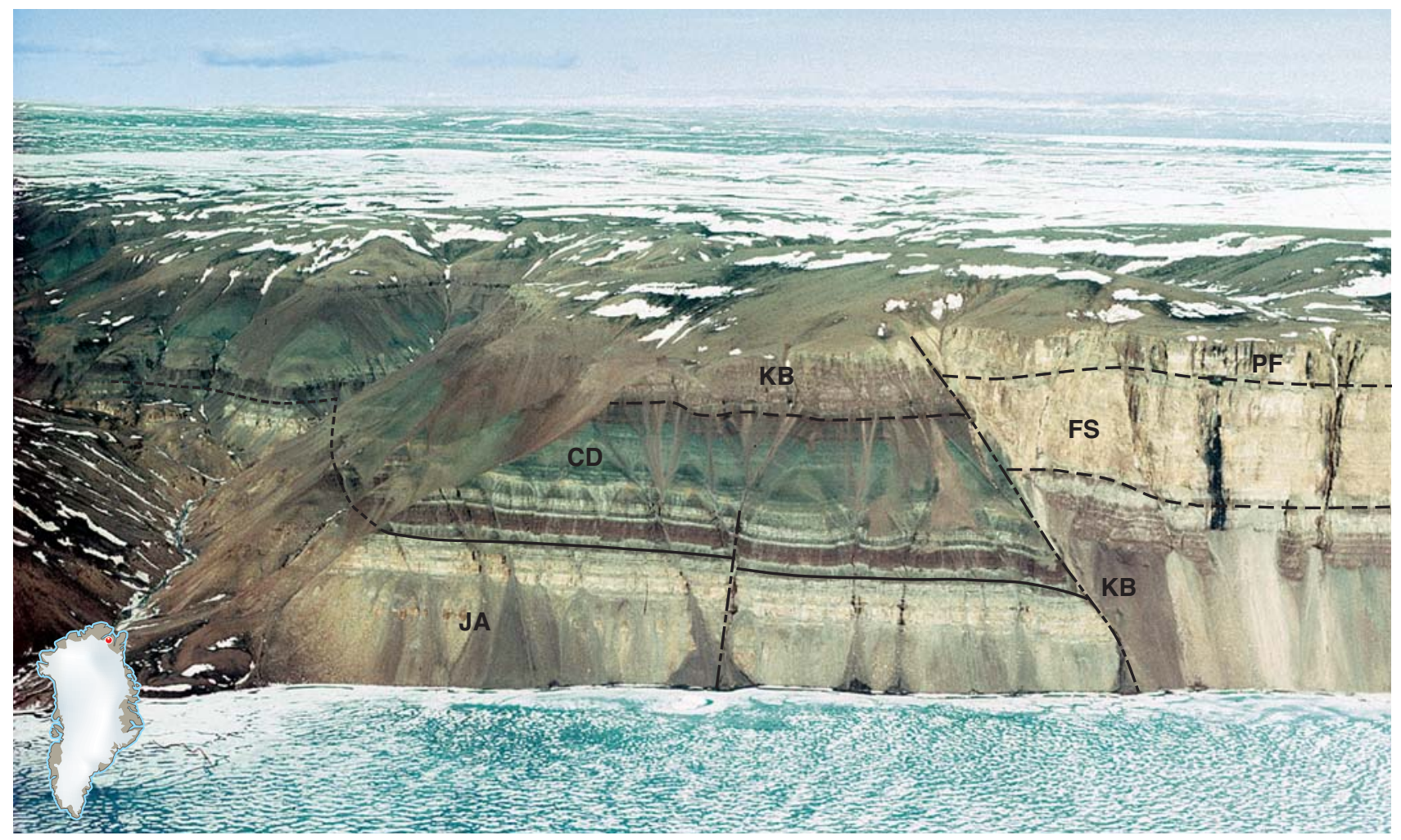

Fig. 25. Hagen Fjord Group on the north-west side of Hagen Fjord, eastern North Greenland. A lower light coloured sandstone (Jyske Ås Formation, JA, $400 \mathrm{~m}$ ) is overlain by a multicoloured sandstone-siltstone association (Campanuladal and Kap Bernhard Formations, CD and KB, $450 \mathrm{~m}$ ), with a light coloured limestone-dolomite succession at the top (Fyns Sø Formation, FS, $170 \mathrm{~m}$, and Portfjeld Formation, PF). The fault has a displacement of $c .300 \mathrm{~m}$ down to the right (north). The section is $c .600 \mathrm{~m}$ high. From Sønderholm et al. 2008.

The lower part of the Eleonore Bay Supergroup (Fig. 26) consists of up to $9000 \mathrm{~m}$ of sandstones, siltstones and minor carbonates assigned to the Nathorst Land Group [44]; these were deposited in a shelf environment with facies associations indicating outer to inner shelf environments (Smith \& Robertson 1999; Sønderholm et al. 2008). The upper part comprises three groups (Lyell Land, Ymer $\varnothing$ and Andrée Land Groups) depicted on the map by a single colour division [43]. Alternating sandstones and silty mudstones of the Lyell Land Group (Fig. 27) reflect deposition in marine shelf environments (Tirsgaard \& Sønderholm 1997; Sønderholm et al. 2008). Individual units are 40-600 m thick with a total thickness of $2800 \mathrm{~m}$. The overlying $1100 \mathrm{~m}$ thick Ymer $\varnothing$ Group records two significant phases of shelf progradation. Depositional environments range from siliciclastic basinal and slope deposits through carbonate slope and shelf deposits to inner shelf siliciclastics and evaporites (Sønderholm \& Tirsgaard 1993; Sønderholm et al. 2008). The latest stage of basin fill is mainly represented by the up to $1200 \mathrm{~m}$ thick Andrée Land Group of bedded limestone and dolomites, with 10-30 m thick units of stromatolitic dolomite. Deposition took place in a carbonate ramp system, with a steepened ramp towards the deep sea to the north-east and a sheltered inner lagoon behind an inner shallow-barrier shoal (Frederiksen \& Craig 1998). The uppermost sequence heralding the Marinoan glaciation of the Tillite Group consists of a strongly retrogradational succession indicating drowning of the carbonate platform and deep marine deposition, followed by a short period of carbonate platform progradation (Sønderholm et al. 2008).

\section{Tillite Group, East Greenland}

The Tillite Group [42] consists of a 700-800 m thick succession of Marinoan-Ediacaran age (c.635 - c.575 Ma) and includes two Marinoan glacigene diamictite formations (Hambrey \& Spencer 1987; Sønderholm et al. 2008). It crops out in East Greenland between latitudes $71^{\circ} 40^{\prime}$ and $74^{\circ} \mathrm{N}$ where it overlies the Eleonore Bay Supergroup with no major hiatus, but locally with an erosional unconformity. The Tillite Group is subdivided into five formations which include sandstones, shales and dolostones in addition to the diamictite formations. 


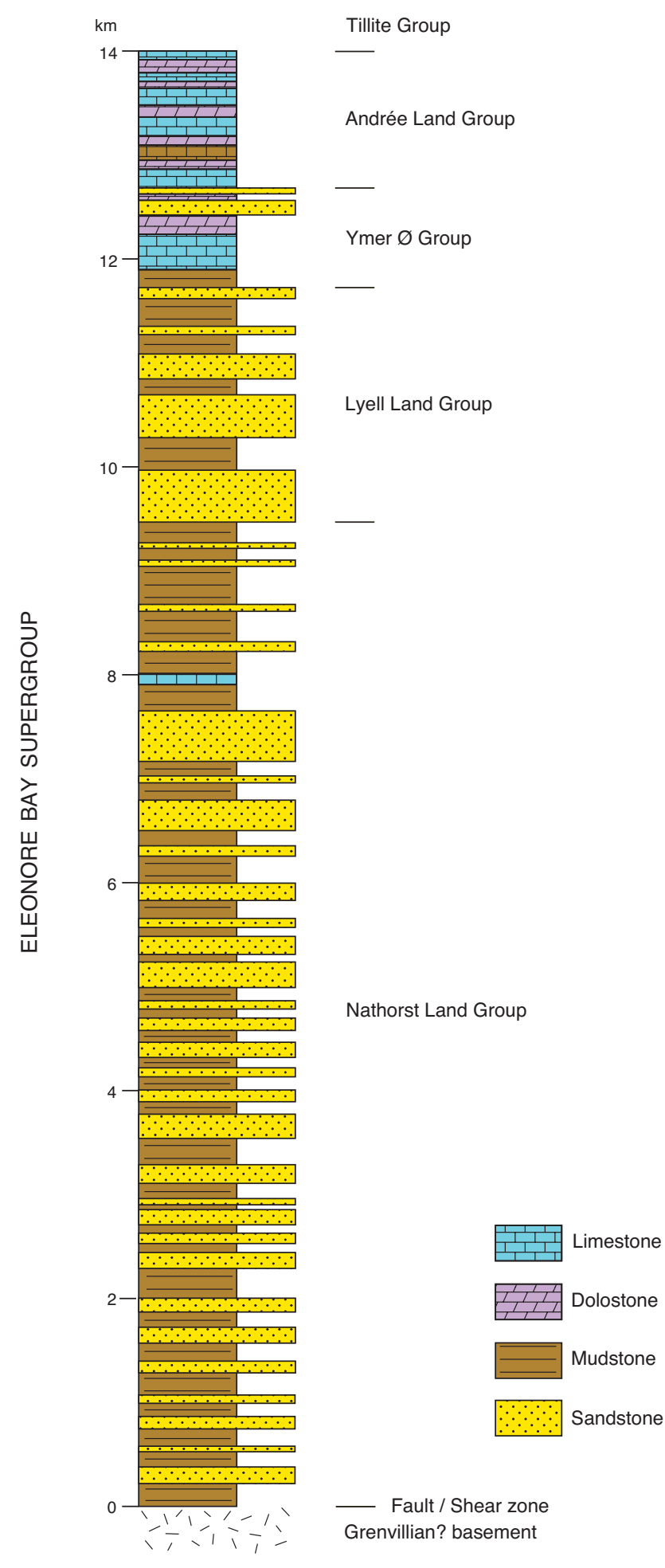

Fig. 26. Schematic composite section of the Neoproterozoic Eleonore Bay Supergroup, central fjord zone $\left(72-74^{\circ} \mathrm{N}\right)$, North-East Greenland. Units on the map: Nathorst Land Group [44]; Lyell Land, Ymer $\varnothing$ and Andrée Land Groups [43]; Tillite Group [42]. Based on Sønderholm \& Tirsgaard (1993) and Sønderholm et al. (2008).
Isolated occurrences of diamictites correlated with the Tillite Group directly overlie crystalline basement complexes in Gåseland $\left(70^{\circ} 15^{\prime} \mathrm{N}\right)$, Charcot Land $\left(71^{\circ} 52^{\prime} \mathrm{N}\right)$ and in the Målebjerg window $\left(73^{\circ} 38^{\prime} \mathrm{N}\right)$, all located in the Caledonian foreland (Henriksen 1986; Moncrieff 1989; Smith \& Robertson 1999); the first two of these are shown on the map by a special symbol [41]. These foreland tillites are directly overlain by Cambrian quartzites or truncated by the Caledonian sole thrust.

\section{Sedimentary rocks of unknown age in the East Greenland Caledonides}

Two successions of low-grade metamorphic rocks occur in the nunatak region between $70^{\circ}$ and $74^{\circ} \mathrm{N}$ underlying Caledonian thrusts. Their correlation with other known successions was uncertain when the map was compiled, and they have been indicated on the map as of 'unknown age' [45].

One succession crops out in the Gaseland window in the south-west corner of the Scoresby Sund region $\left(70^{\circ} 15^{\prime} \mathrm{N}\right)$, overlying Archaean crystalline basement rocks. A thin sequence of weakly metamorphosed marbles and chloritic schists, often highly sheared adjacent to the Caledonian sole thrust, overlies diamictites [28] preserved in erosional depressions in the gneiss surface (Phillips \& Friderichsen 1981). The diamictites are now correlated with the Marinoan Tillite Group of the fjord zone (Moncrieff 1989), suggesting the overlying sheared marbles and schists are either of early Palaeozoic age or belong to a thin lowermost thrust assemblage of diverse lithologies distinguished as the Gemmadal thrust sheet in the central part of the fjord region $\left(c .73^{\circ} 30^{\prime} \mathrm{N}\right.$; Higgins \& Leslie 2008).

The second succession, traditionally known as the 'Eleonore Sø series', crops out in Arnold Escher Land $\left(74^{\circ} \mathrm{N}\right.$; Katz 1952). Field studies in 1997 have shown the succession to occur in a tectonic window beneath Caledonian thrust units of metasedimentary rocks and gneisses. The Eleonore Sø series comprises low-grade metamorphic sandstones, shales and carbonates associated with volcanic rocks (tuffs and pillow lavas). U-Pb ion probe studies on zircons from a quartz porphyry intruding the Eleonore Sø series indicate a minimum emplacement age of $1915 \pm 16 \mathrm{Ma}$ (Kalsbeek et al. 2008). This succession is overlain unconformably by a thick Cambrian quartzite unit which preserves abundant Skolithos (Slottet Formation) and a few hundred metres of Lower Palaeozoic carbonates (Målebjerg Formation), recently described and defined by Smith et al. (2004). 


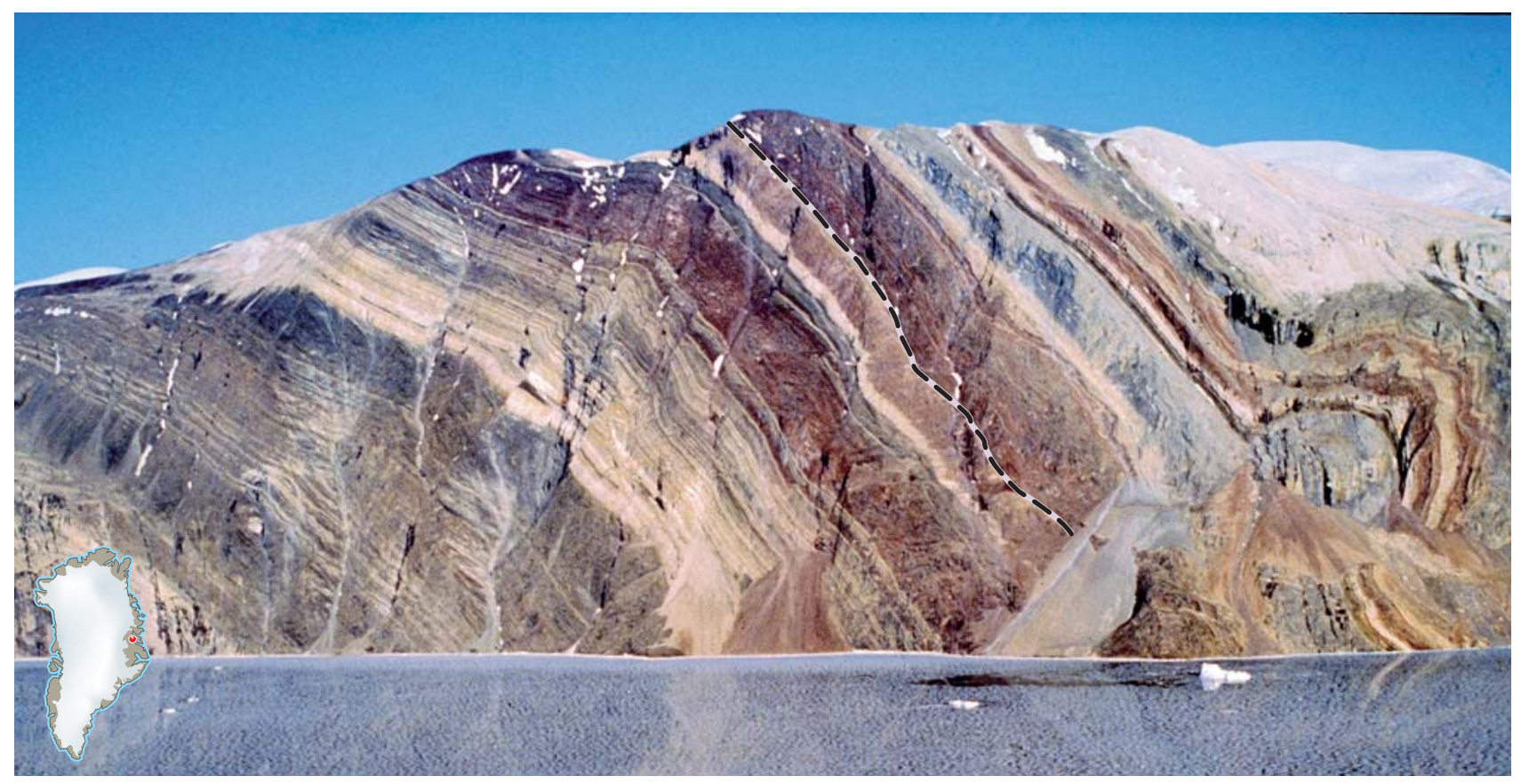

Fig. 27. Part of the upper Eleonore Bay Supergroup, west side of Ymer $\varnothing\left(c .73^{\circ} \mathrm{N}\right)$, North-East Greenland. Succession is approximately $2 \mathrm{~km}$ in thickness and includes from left to right: Lyell Land Group (apart from the two lowest formations) and to the right of the black dashed line Ymer $\varnothing$ Group (the lowest five of seven formations). Photo: M. Sønderholm.

\section{Carbonatites, kimberlites and associated rocks, West Greenland}

In addition to the $3007 \mathrm{Ma}$ Tupertalik carbonatite [84] mentioned earlier, two younger occurrences of carbonatite are shown on the geological map, the $565 \mathrm{Ma}$ Sarfartoq carbonatite complex [61] south of Søndre Strømfjord at $66^{\circ} 30^{\prime} \mathrm{N}$ (Secher \& Larsen 1980), and the c. $165 \mathrm{Ma}$ (middle Jurassic) Qaqarssuk carbonatite complex [59], east of Maniitsoq/Sukkertoppen at $65^{\circ} 23^{\prime} \mathrm{N}$ (Knudsen 1991). Since the compilation of the map another occurrence of carbonatitic rocks has been detected within the Archaean craton, the $158 \mathrm{Ma}$ Tikiusaaq carbonatite complex at $64^{\circ} \mathrm{N}, 49^{\circ} 46^{\prime} \mathrm{W}, c$. $100 \mathrm{~km}$ east of Nuuk/Godthåb (Steenfelt et al. 2006). Carbonatites also occur within some of the intrusive complexes in the Mesoproterozoic Gardar Province (Upton et al. 2003). A review of all alkaline-ultramafic and carbonatitic rocks in West Greenland (except the newly discovered Tikuusaaq occurrence) has been presented by Larsen \& Rex (1992). These rocks are invariably related to episodes of continental rifting. They were formed from small melt fractions generated deep within the lithospheric mantle, and many dykes contain xenoliths of both mantle and crustal origin.
Most carbonatite complexes are associated with swarms of ultramafic dykes, kimberlites, aillikites etc. (Nielsen et al. 2009), here collectively termed ultramafic lamprophyres (sensu lato) (UML dykes). The dykes are too small to be shown on the geological map, but they are important for diamond exploration. Hundreds of diamonds have been recovered from a single dyke in the Sarfartoq region, the largest of which are $c .4$ carats and of good gem quality (Hutchison \& Heaman 2008). A regional overview of diamond occurrences in southern West Greenland is given by Jensen et al. (2004).

Recent investigations of UML dykes have concentrated on the areas around Sisimiut/Holsteinsborg, Sarfartoq and Maniitsoq/Sukkertoppen, the 'Diamond Province' of southern West Greenland (Nielsen et al. 2009). They fall in several age groups (Secher et al. 2009). UML dykes in the Sisimiut region have yielded ages of c. $590 \mathrm{Ma}$ (Scott 1981). Dykes in a wide region around the Sarfartoq carbonatite complex have Neoproterozoic ages between 604 and $555 \mathrm{Ma}$. Similar ages were found for dykes in the Maniitsoq region, but samples collected around the Qaqarssuk carbonatite complex are of Jurassic age 152-166 Ma. Only Neoproterozoic dykes have as yet proved to be diamondiferous (Secher et al. 2009). 


\section{The Palaeozoic Franklinian Basin of North Greenland and Ellesmere Island}

The Palaeozoic Franklinian Basin extends from the Canadian Arctic Islands across North Greenland to Kronprins Christian Land in eastern North Greenland, an E-W distance of $2000 \mathrm{~km}$ (Peel \& Sønderholm 1991); only part of the Canadian segment of the basin is represented on the map. The preserved part of the succession shows that deposition in this E-W-trending basin began in the latest Precambrian and continued until at least the earliest Devonian in Greenland and later Devonian to earliest Carboniferous in Canada; sedimentation was brought to a close by the mid- to late Palaeozoic Ellesmerian orogeny. In the Canadian Arctic Islands deposition continued more or less continuously throughout the Devonian and probably into the earliest Carboniferous. Deposition of clastic sediments of Middle and Late Devonian age in the southern part of the Franklinian Basin in the Canadian Arctic Islands reflects an early orogenic event with uplift and erosion starting in latest Silurian time (Trettin 1991, 1998).

Deposition in the Franklinian Basin in North Greenland took place along a passive continental margin, and its evolution during the Early Palaeozoic resulted in a distinctive differentiation into a southern, broad, shallow shelf bordered to the north by a slope with moderate water depths and a broad deep-water trough (Higgins et al. 1991). The shelf succession is dominated by carbonates and reaches $3 \mathrm{~km}$ in thickness, whereas the trough deposits are dominated by siliciclastic rocks and have a total thickness of $c .8 \mathrm{~km}$ (Fig. 28). The shelf-trough boundary was probably controlled by deep-seated faults, and with time the trough expanded southwards to new fault lines, with final foundering of the shelf areas in the Silurian. The sedimentary successions in the North Greenland and Canadian (Ellesmere Island) segments of the basin show close parallels in development, although different lithostratigraphic terminologies are employed (Trettin 1991, 1998).

The evolution of the Franklinian Basin in North Greenland has been divided into seven stages, with significant changes in the sedimentary regime linked to southward expansion of the basin margin (Higgins et al. 1991; Henriksen \& Higgins 2000).

\section{Uppermost Neoproterozoic - Silurian in North Greenland}

The oldest shelf deposits range from latest Neoproterozoic to Cambrian in age, and consist of a mixture of car- bonates and siliciclastic sediments [25]; they crop out in a narrow, almost continuous zone extending from Danmark Fjord in the east through southern Peary Land to southern Wulff Land in the west (Ineson \& Peel 1997). The southernmost outcrops farther to the west in Inglefield Land rest on crystalline basement. Three principal divisions are recognised: a lower varied sequence of sandstones, dolomites and mudstones (Skagen Group), a middle dolomitic unit locally with stromatolites (Portfjeld Formation), and an upper siliciclastic unit (Buen Formation). Total thickness reaches $1-2 \mathrm{~km}$. The Buen Formation in North Greenland is noted at one location for its well-preserved soft-bodied fossil fauna (Conway Morris \& Peel 1990, 1995, 2008).

Early Cambrian deep-water turbidite trough sediments [26] dominate the northernmost parts of Greenland bordering the Arctic Ocean, and they also crop out in a broad E-W-trending belt north of Lake Hazen in Ellesmere Island. The lower part (Nesmith Beds in Canada, Paradisfjeld Group in Greenland) comprises calcareous mudstones and dolomites with, in Greenland, carbonate conglomerates at the top. The upper division (Polkorridoren Group) is made up of thick units of sandy turbidites and mudstones. The thickness of these two divisions totals about 3-4 km (Friderichsen et al. 1982; Higgins et al. 1991).

Carbonate sedimentation resumed on the platform in the late Early Cambrian (Ineson et al. 1994; Ineson \& Peel 1997) and continued with minor siliciclastic intervals until the early Silurian, giving rise to an up to $1500 \mathrm{~m}$ thick succession of carbonate lithologies (Brønlund Fjord, Tavsen Iskappe, Ryder Gletscher and Morris Bugt groups, and Petermann Halvø and Ymers Gletscher formations [23]). Throughout the period sedimentation was influenced by differential subsidence and southwards expansion of the deep-water trough. Uplift in eastern North Greenland led to erosion of the Cambrian to late Early Ordovician succession in Kronprins Christian Land, after which the Middle Ordovician to Early Silurian platform succession was deposited. A broad zone of outcrop can be traced from Danmark Fjord to Washington Land, with outliers to the south-west in northern Inglefield Land. On Ellesmere Island extensive outcrops are found on Judge Daly Promontory. The up to 1500 m thick succession (Fig. 29) of massive dolomites, carbonate grainstones, carbonate mass-flow deposits and evaporites reflects both progradation and aggradation phases of platform evolution.

The Cambrian - Early Silurian starved slope and trough deposits (Surlyk \& Hurst 1984) are represented by a condensed succession, dominated for the most part 


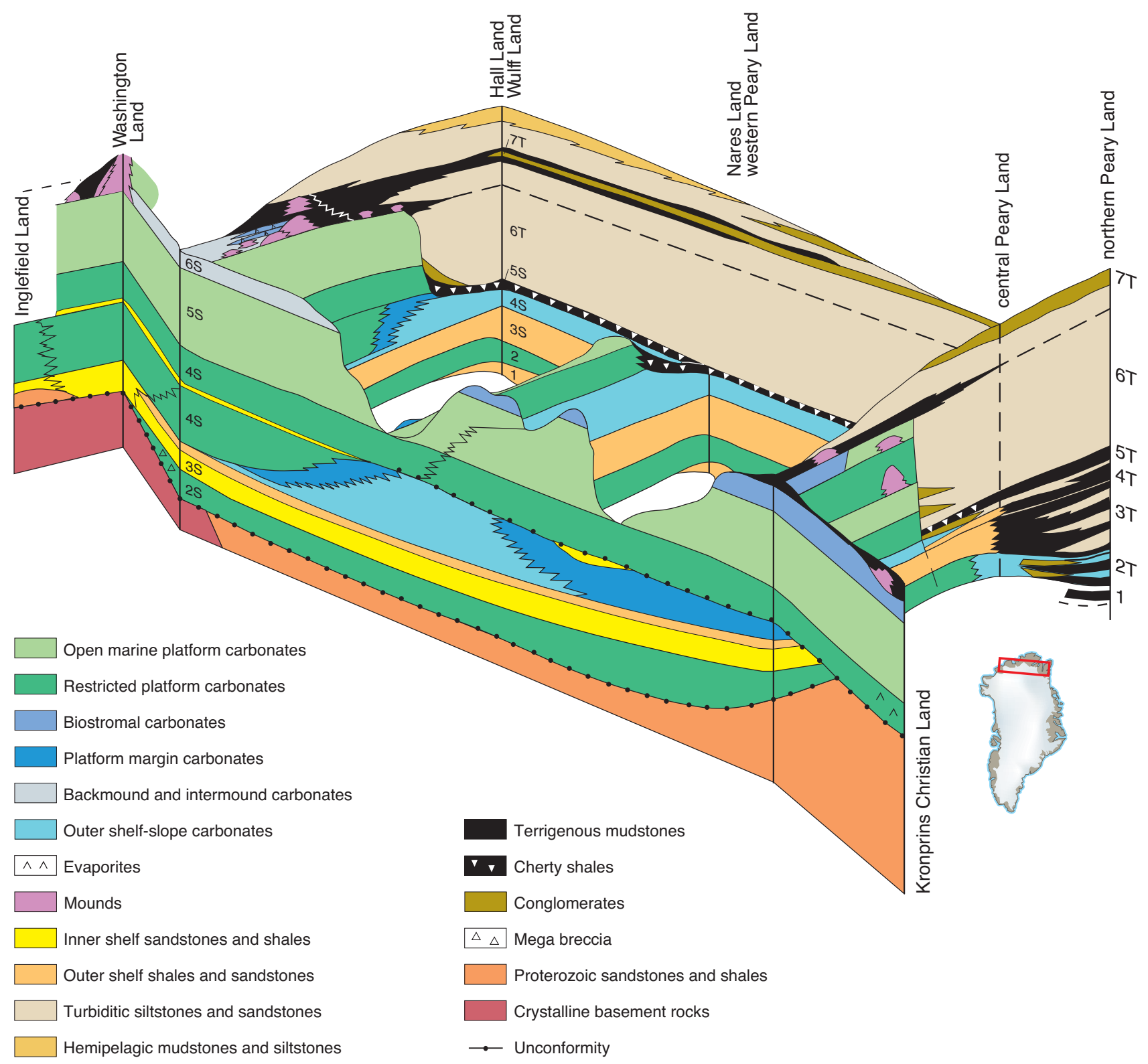

Fig. 28. Block diagram illustrating relationships between shelf, slope and trough sequences in the Lower Palaeozoic Franklinian Basin of North Greenland. The schematic fence diagram covers a region of $c .700 \mathrm{~km}$ east-west and $c .200 \mathrm{~km}$ north-south. Shelf stages (S) and trough stages (T) are divided into time intervals. 1: late Neoproterozoic? - Early Cambrian; 2: Early Cambrian; 3: Early Cambrian; 4: Late Early Cambrian - Middle Ordovician; 5: Middle Ordovician - Early Silurian; 6: Early Silurian; 7: later Silurian.

Units on the map: Portfjeld and Buen Formations [25] - stages 2-3 S; Brønlund Fjord, Tavsen Iskappe, Ryder Gletscher and Morris Bugt Groups and Petermann Halvø and Ymers Gletscher Formations [23] - stages 4-5 S; Washington Land Group exclusive above mentioned formations [21] - stages 6-7 S; Skagen, Paradisfjeld and Polkorridoren Groups [26] - stages 1, 2-3 T; Vølvedal and Amundsen Land Groups [24] - stages 4-5 T; Peary Land Group [22] - stages 6-7 T. Modified from Higgins et al. (1991) and with information from M. Sønderholm (personal communication 1998).

by carbonate mudstones and carbonate conglomerates in the lower part (Vølvedal Group) and by cherts and cherty shales in the upper part (Amundsen Land Group) [24]. In central North Greenland thin-bedded turbidites characterise both the lower and upper parts of the suc- cession. In Greenland these deposits occur in thrust slices and anticlinal fold cores (Fig. 30; Soper \& Higgins 1987, 1990); in Ellesmere Island they occur mainly in scattered anticlinal fold cores. Thicknesses vary greatly, from a minimum of $50-150 \mathrm{~m}$ to a maximum of about $1 \mathrm{~km}$. 
Silurian carbonate ramp and rimmed shelf deposits (Washington Land Group [21]) crop out in an almost continuous narrow strip extending from Kronprins Christian Land in the east to Washington Land in the west (Hurst 1980, 1984; Sønderholm \& Harland 1989; Higgins et al. 1991). The comparable deposits of this age in Ellesmere Island have been included in an extension of unit [23] - see legend. Sedimentation on the platform was closely linked to the dramatic increase in deposition rates in the trough and was initiated in the Early Silurian (early Late Llandovery) by a major system of sandstone turbidites (Peary Land Group [22]) derived from the rising Caledonian mountains in the east (Hurst \& Surlyk 1982; Surlyk \& Hurst 1984; Larsen \& Escher 1985). Loading effects of the turbidites led to downflexing of the outer platform and expansion of the trough. With progressive drowning of the shelf, carbonate deposition was only locally maintained on isolated reef mounds up to $300 \mathrm{~m}$ high (e.g. Samuelsen Høj Formation, Hauge Bjerge Formation). Mound formation terminated over much of the region during the Late Llandovery, but persisted in western North Greenland into the Late Silurian (Early Ludlow).
The Silurian turbidite trough deposits occur in a broad belt traceable across North Greenland (Peary Land Group [22]) and Ellesmere Island; the commencement of turbidite sedimentation was essentially synchronous in both regions within the limits of biostratigraphic resolution (Trettin 1991). The trough sediments represent the deposits of a major E-W-trending sand-rich turbidite system. Palaeocurrent directions in North Greenland indicate a source area in the rising mountains of the Caledonian fold belt to the east (Higgins et al. 1991; Henriksen \& Higgins 2000), whereas current directions in Ellesmere Island demonstrate an additional source area in the north. The initial phase of sandstone turbidite deposition in North Greenland laid down between 500 and $2800 \mathrm{~m}$ of sediment within the Early Silurian (Late Llandovery); this filled the deep-water trough, buried the former shelf escarpment and led to deposition of black mudstone over extensive former shelf areas. Renewed prograding fan systems built up and turbidite deposition continued throughout the Silurian, punctuated by an episode of chert conglomerate deposition in the middle Wenlockian (Surlyk 1995). Palaeontological evidence from the youngest deposits in North Greenland indicates a Late

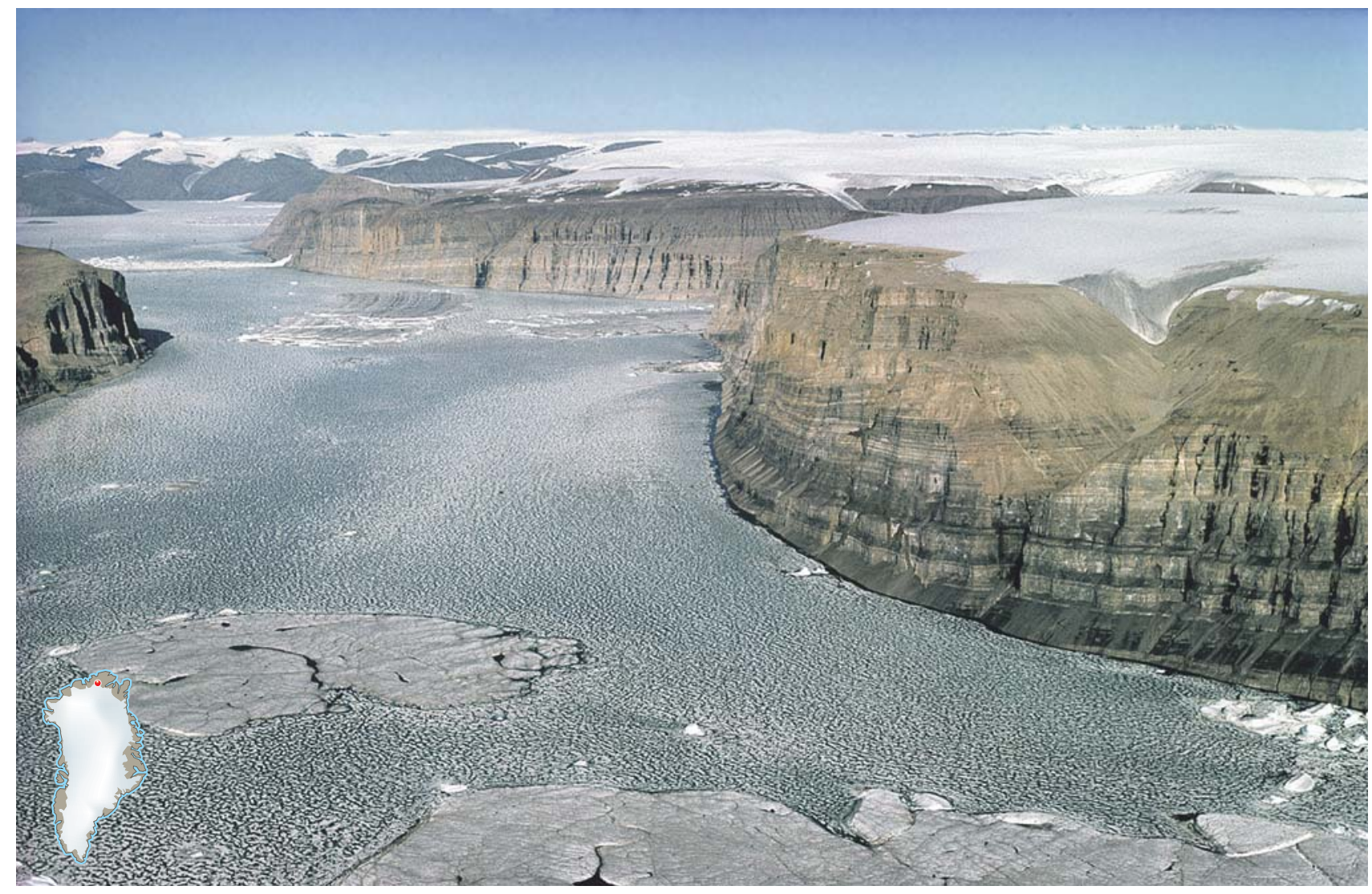

Fig. 29. Cambro-Ordovician platform margin sequence in the foreground and Ordovician shelf sequence clastic rocks in the middle distance. View from the south, inner J.P. Koch Fjord, central North Greenland. Profile height in the foreground is $c .500 \mathrm{~m}$. 


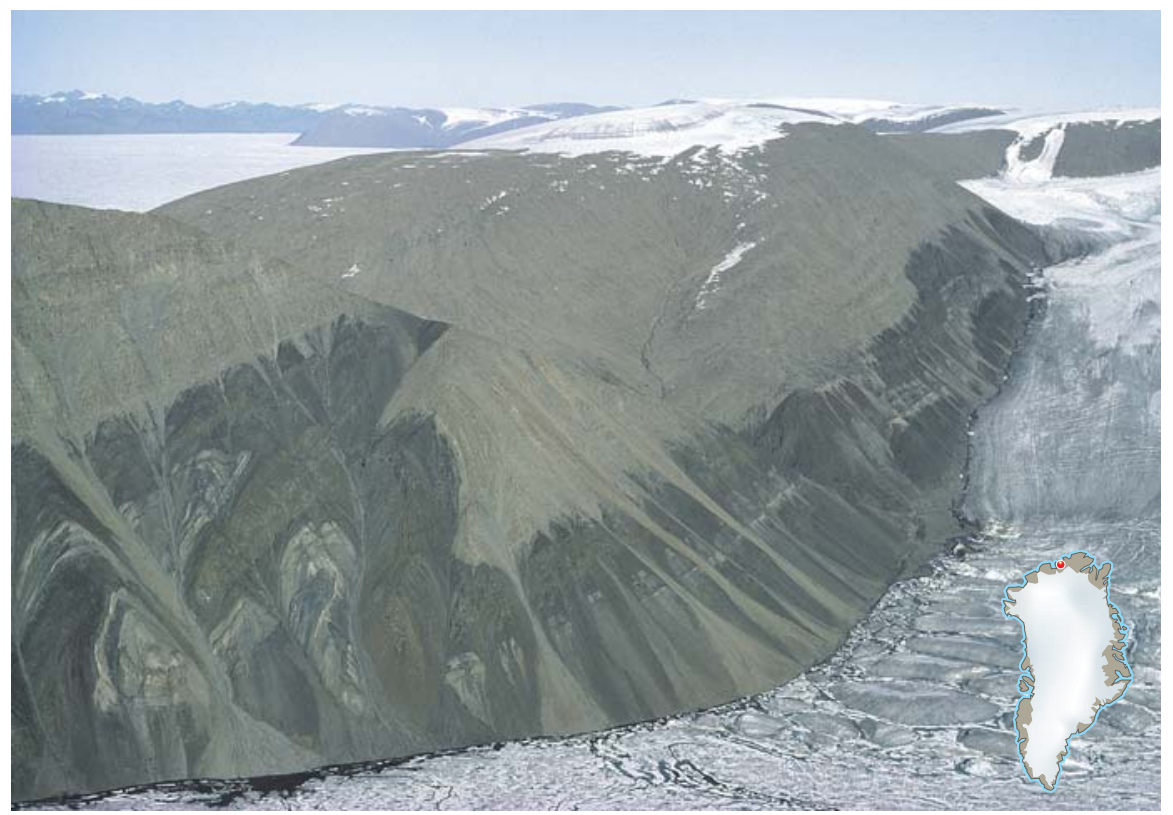

Fig. 30. Middle Ordovician - Lower Silurian sediments in the deep-water sequence of the Franklinian Basin (Amundsen Land Group dark unit; Merqujôq Formation light coloured unit). The sedimentary rocks were folded into south-facing tight folds during the Ellesmerian orogeny. Northeast cape of Victoria Fjord, central North Greenland, view towards the east. Profile height is $c .400 \mathrm{~m}$.

Silurian (Pridoli) to Early Devonian age (Bendix-Almgreen \& Peel 1974; Blom 1999). In Ellesmere Island this phase of turbidite deposition persisted into the Lower Devonian; farther to the west in the Canadian Arctic Islands clastic sedimentation associated with the advance of Ellesmerian deformation continued through the Devonian into the earliest Carboniferous.

\section{Proterozoic-Silurian exotic terrane of Ellesmere Island (Pearya)}

The geological province of Pearya, now recognised as an exotic terrane, is confined to northernmost Ellesmere Island (Trettin 1991, 1998). Pearya appears to have been accreted during the latest Ordovician to early Silurian,

$\mathrm{N}$

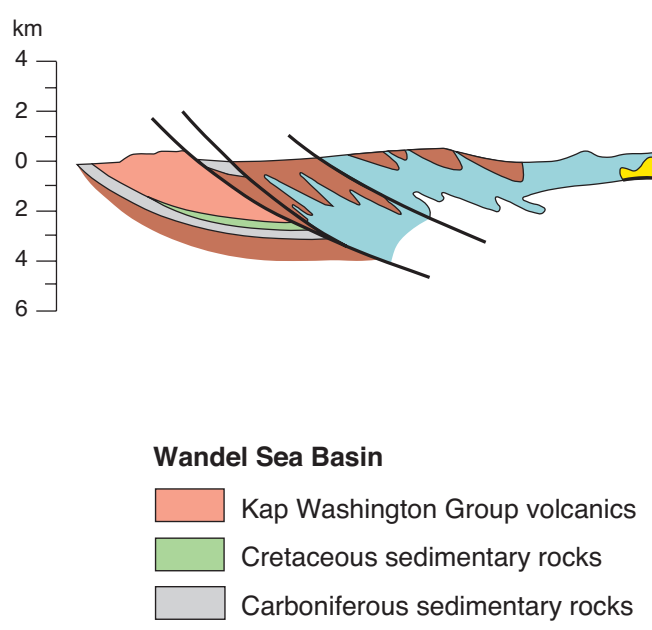

Fig. 31. N-S structural cross-section through the North Greenland (Ellesmerian) fold belt and its southern foreland in North Greenland (c. 39 $\mathrm{W}$, westernmost Peary Land). Compiled from Soper \& Higgins (1990) and Henriksen (1992). 
and underwent further convergence or accretion during the late Silurian (de Freitas et al. 1999; Tessensohn \& Roland 2000). On the geological map it is represented by two divisions: late Mesoproterozoic crystalline rocks [52] and a Neoproterozoic to Late Silurian complex of undifferentiated metasedimentary and metavolcanic rocks (the mainly exotic terrane [2] of the map legend). The rocks of the latter division are stratigraphically or structurally associated with the formation of the Franklinian deep-water basin. The crystalline rocks consist of granitoid gneisses and lesser amounts of amphibolite, schist, marble and quartzite in several outcrop areas with different structural settings and trends. The younger supracrustal complexes include different carbonate and clastic sediments together with varied acid and mafic volcanic rocks. These supracrustal rocks have been folded and constitute the Markham Fold Belt, which is a complex region that fringes the Pearya terrane on the southeast. The Pearya exotic terrane is noted for emplacement of granite plutons associated with the early Middle Ordovician M'Clintock orogeny, not recorded elsewhere in Ellesmere Island.

\section{Ellesmerian orogeny in North Greenland and Ellesmere Island}

The Palaeozoic Ellesmerian orogeny, which brought sedimentation in the Franklinian Basin to a close, involved compression of the Lower Palaeozoic trough succession against the carbonate shelf to the south following collision with an unknown continent to the north (Higgins et al. 2000). The resulting Ellesmerian fold belts of both North Greenland and northern Ellesmere Island are characterised by E-W- to NE-SW-trending chains of folds, broadly parallel to the main facies boundaries within the Franklinian Basin. In the North Greenland fold belt deformation is most intense in the north, where three phases of folding are recognised and metamorphic grade reaches low amphibolite facies. Deformation decreases southwards, and the southern part of the fold belt is a thin-skinned fold and thrust zone (Soper \& Higgins 1987, 1990; Higgins et al. 1991) that coincides with the region which was transitional between the platform and trough for much of the Cambrian (Fig. 31). A prominent belt of major folds is traceable between northern Nyeboe Land and J.P. Koch Fjord, and farther east spectacular imbricate thrusts occur north of the head of Frederick E. Hyde Fjord (Pedersen 1986). The same general pattern of Ellesmerian deformation is seen in Ellesmere Island, except that the southernmost belt of folding propagated some $100 \mathrm{~km}$ southward into the platform, producing the large-scale, concentric-style folding seen north-west of Kennedy Kanal. The age of the Ellesmerian orogenic deformation in North Greenland is not well constrained, but is assumed to be Late Devonian to Early Carboniferous.

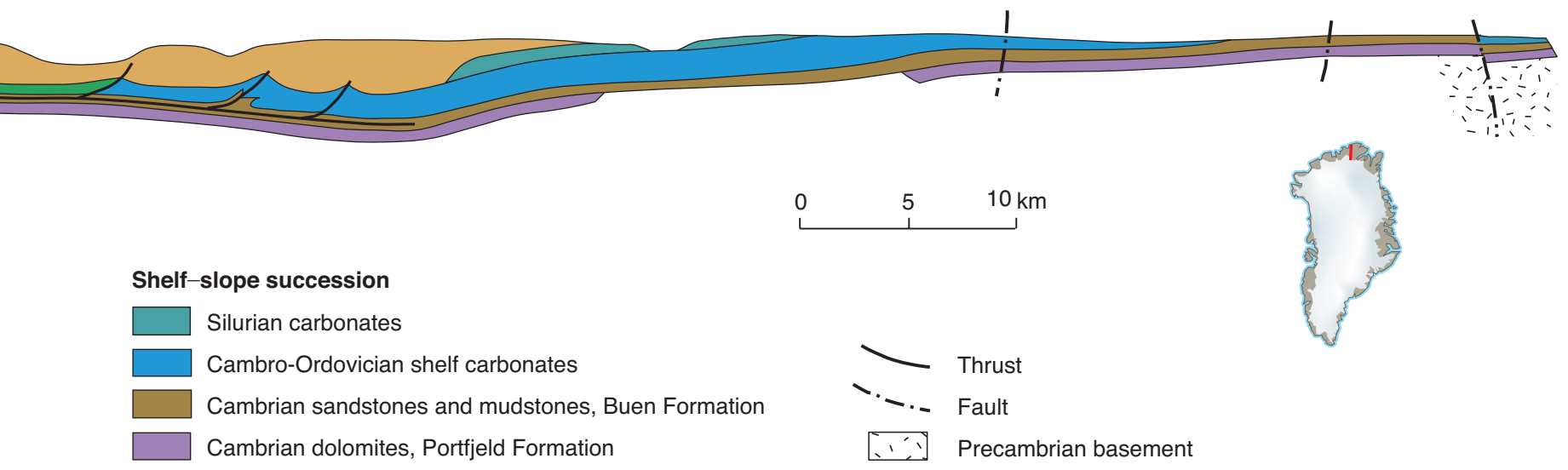




\section{Lower Palaeozoic of East Greenland Cambrian-Ordovician sediments in the Caledonian fold belt}

Cambrian-Ordovician rocks [40] make up an approximately $4500 \mathrm{~m}$ thick succession within the East Greenland Caledonian fold belt between latitudes $71^{\circ} 40^{\prime}$ and $74^{\circ} 30^{\prime} \mathrm{N}$ (Haller 1971; Peel 1982; Henriksen 1985), and were placed in the Kong Oscar Fjord Group by Smith et al. (2004). The sedimentary rocks laid down in this Lower Palaeozoic basin are disturbed by large-scale folding and faulting, but are non-metamorphic. Limestones and dolomites dominate the succession which spans the period from the earliest Cambrian to the Late Ordovician (Fig. 32); uppermost Ordovician to Silurian sediments are not known in East Greenland (Smith \& Rasmussen 2008).

The Lower Palaeozoic succession begins with $c .200 \mathrm{~m}$ of Lower Cambrian sandstones and siltstones with trace fossils, interpreted as deposited in a tidal to shallow marine environment. These are overlain by a c. $2800 \mathrm{~m}$ thick Lower Cambrian - Middle Ordovician (Darriwilian) succession of alternating limestones and dolomites, containing a diversified shelf-type Pacific fauna (Cowie \& Adams 1957; Peel \& Cowie 1979; Peel 1982).

Stable shelf conditions prevailed throughout the Early Palaeozoic, with the progressive lithology changes considered to reflect increasing isolation from detrital sources

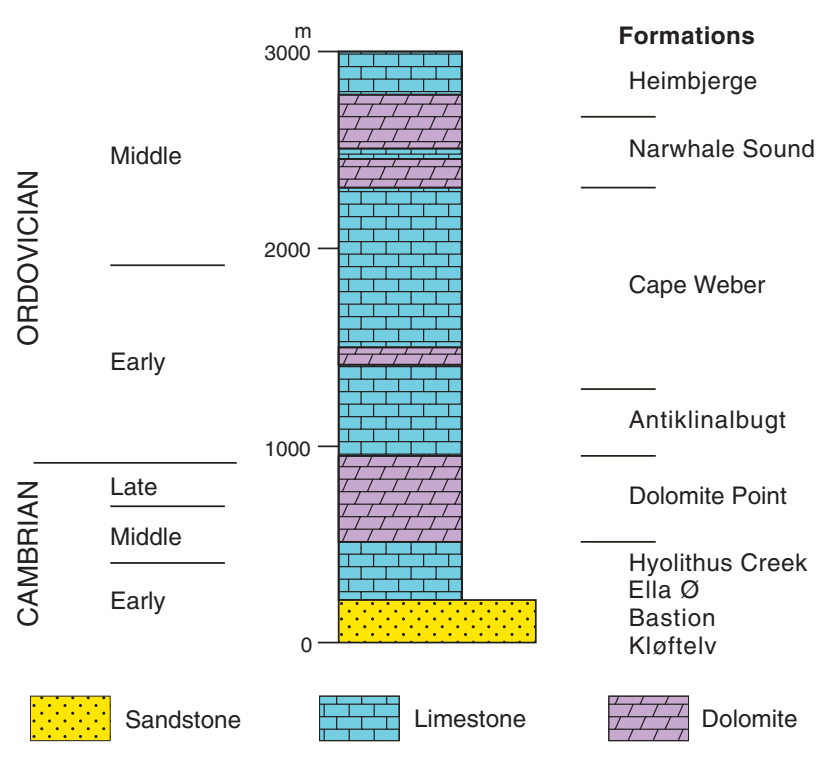

Fig. 32. Schematic lithostratigraphic composite section of the CambroOrdovician sediments in East Greenland $\left(c .71^{\circ} 30^{\prime}-74^{\circ} 30^{\prime} \mathrm{N}\right)$. Unit [40] on the map. Thicknesses after Smith \& Rasmussen (2008).
(Swett \& Smit 1972). Sedimentary and organic-sedimentary structures indicate generally very shallow depositional environments, implying that sedimentation and subsidence rates were roughly equal. The absence of angular unconformities reflects a non-tectonic environment. The Pacific fauna indicates that these areas were developed on the western margin of the proto-Atlantic (Iapetus) ocean.

\section{Caledonian orogeny in East and North-East Greenland}

The Caledonian fold belts on both sides of the North Atlantic developed as a consequence of collision between the continents of Laurentia to the west and Baltica to the east following closure of the proto-Atlantic ocean (Iapetus; Higgins et al. 2008). The East Greenland Caledonian fold belt is well exposed between $70^{\circ}$ and $81^{\circ} 30^{\prime} \mathrm{N}$ as a $1300 \mathrm{~km}$ long and up to $300 \mathrm{~km}$ wide coast-parallel belt. Large regions of the fold belt are characterised by reworked Precambrian basement rocks $[74,70,52]$, overlain by Meso- to Neoproterozoic [46-43] and lower Palaeozoic [40] sedimentary rocks (Fig. 33), all of which form parts of westward-directed major thrust sheets. The Palaeoproterozoic basement gneiss complexes locally preserve traces of Proterozoic fold structures (Fig. 34), and have been reworked during Caledonian orogenesis.

The onshore East Greenland Caledonian orogen is composed of far-travelled, foreland-propagating thrust sheets that were derived from the Laurentian margin and translated westward across the orogenic foreland (Higgins $\&$ Leslie 2000, 2008). The deepest preserved level of the orogen is found north of Danmarkshavn $\left(76^{\circ} 40^{\prime} \mathrm{N}\right)$ where abundant Caledonian eclogitic enclaves occur in the Palaeoproterozoic basement gneisses (Gilotti 1993; Brueckner et al. 1998; Gilotti et al. 2008). Mediumtemperature high-pressure eclogite facies metamorphism has been dated at 410-390 Ma (Gilotti et al. 2008).

Central parts of the orogen $\left(70-75^{\circ} \mathrm{N}\right)$ are formed by a pile of several thrust sheets that in their western parts overlie foreland windows (Higgins et al. 2004a). The individual thrust sheets include Archaean-Palaeoproterozoic gneiss complexes overlain by thick successions of latest Mesoproterozoic to earliest Neoproterozoic sedimentary rocks (Krummedal supracrustal sequence). In the highest thrust sheet these sedimentary rocks preserve evidence of early Neoproterozoic orogenesis (migmatites and 940-910 Ma augen granites). Caledonian metamorphism led to emplacement of a suite of Caledonian granites, some of which migrated into the basal parts of 


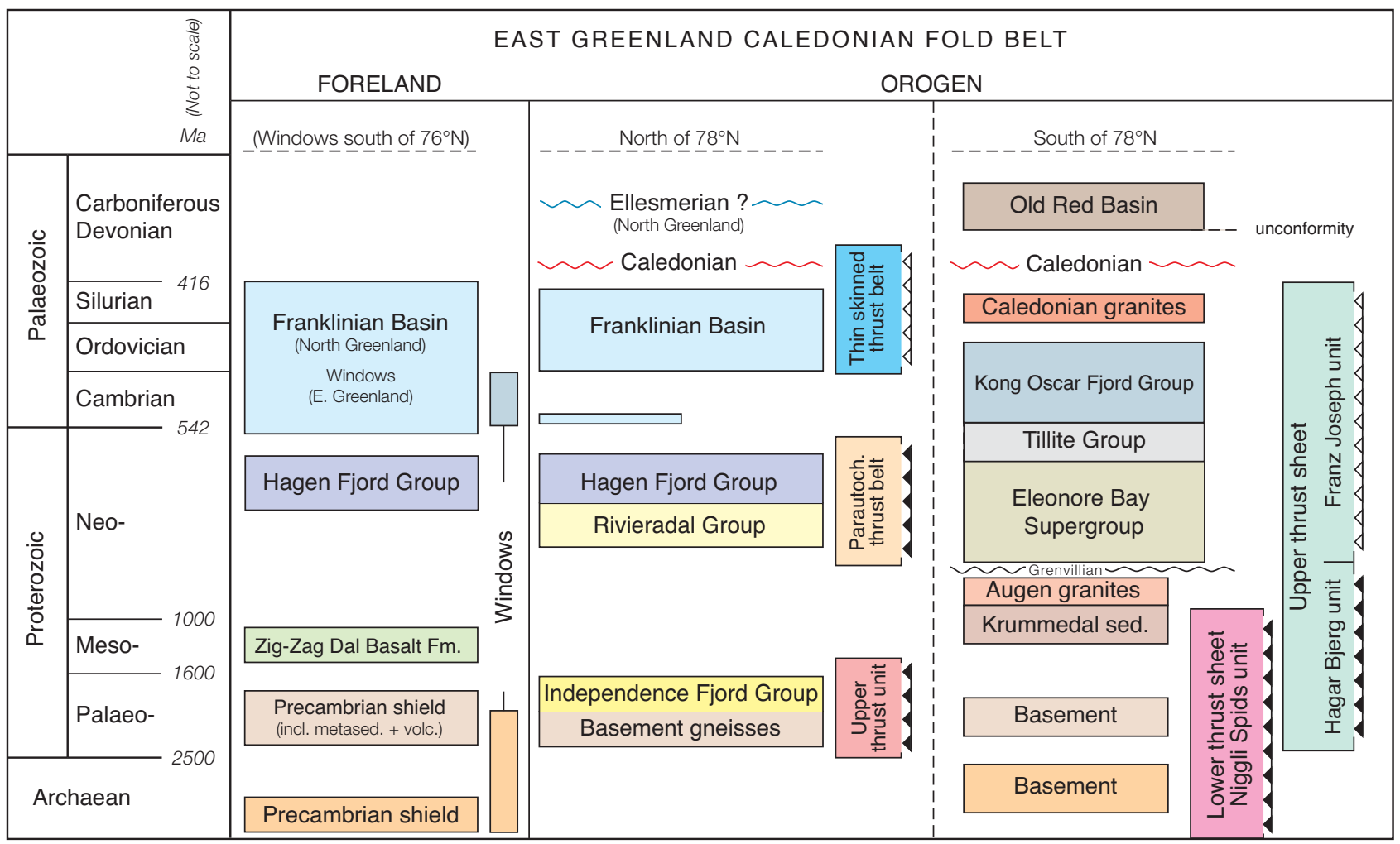

$\nabla \nabla \nabla \nabla$ Detachment

Major thrust

Orogeny

Fig. 33. Schematic diagram showing lithostratigraphy and structural units with pre-Caledonian and Caledonian elements occurring in the East Greenland Caledonian fold belt.

the overlying Eleonore Bay Supergroup (see also below; Kalsbeek et al. 2008b). Extensional structures characterise some of the late tectonic phases (Strachan 1994; Hartz \& Andresen 1995; Andresen et al. 1998; Gilotti $\&$ McClelland 2008). The northernmost part of the fold belt in Kronprins Christian Land preserves high-level thin-skinned structures. Reviews of the East Greenland Caledonides have been presented by Haller (1971), Henriksen \& Higgins (1976), Henriksen (1985) and Higgins et al. (2008).

\section{Caledonian intrusions and plutonic rocks}

During the Caledonian orogeny widespread migmatisation took place in the crystalline complexes in the southern part of the fold belt and a suite of late to post-kinematic plutons [54] was emplaced in the region between Scoresby Sund $\left(70^{\circ} \mathrm{N}\right)$ and Bessel Fjord $\left(76^{\circ} \mathrm{N}\right)$.

North of latitude $72^{\circ} \mathrm{N}$ the intrusions were emplaced mainly in the boundary zone between the Neoproterozoic
Eleonore Bay Supergroup sedimentary rocks and the adjacent metamorphic complexes (Jepsen \& Kalsbeek 1998; Fig. 35), whereas in southern areas plutonic bodies are widespread within the crystalline complexes. Granodiorites and granites are the most abundant types and have yielded intrusive ages ranging from $466 \mathrm{Ma}$ to c. $420 \mathrm{Ma}$. Most ages occur in the range $440-425 \mathrm{Ma}$ (Kalsbeek et al. 2008b). The Caledonian granites in the northernmost part of their region of occurrence $\left(75-76^{\circ} \mathrm{N}\right)$ were emplaced about $430-425 \mathrm{Ma}$ ago and these contain a large proportion of crustally derived components (Strachan et al. 2001).

The southernmost known 'Caledonian' intrusion is the Batbjerg complex (Brooks et al. 1981) which occurs in a late Archaean granulite facies terrain at Kangerlussuaq $68^{\circ} 40^{\prime} \mathrm{N}$, c. $200 \mathrm{~km}$ south of the nearest exposed part of the Caledonian orogenic belt. The Batbjerg complex consists largely of pyroxenites including some leucitebearing types [60], and has been dated at $c .440 \mathrm{Ma}$ (Brooks et al. 1976). 


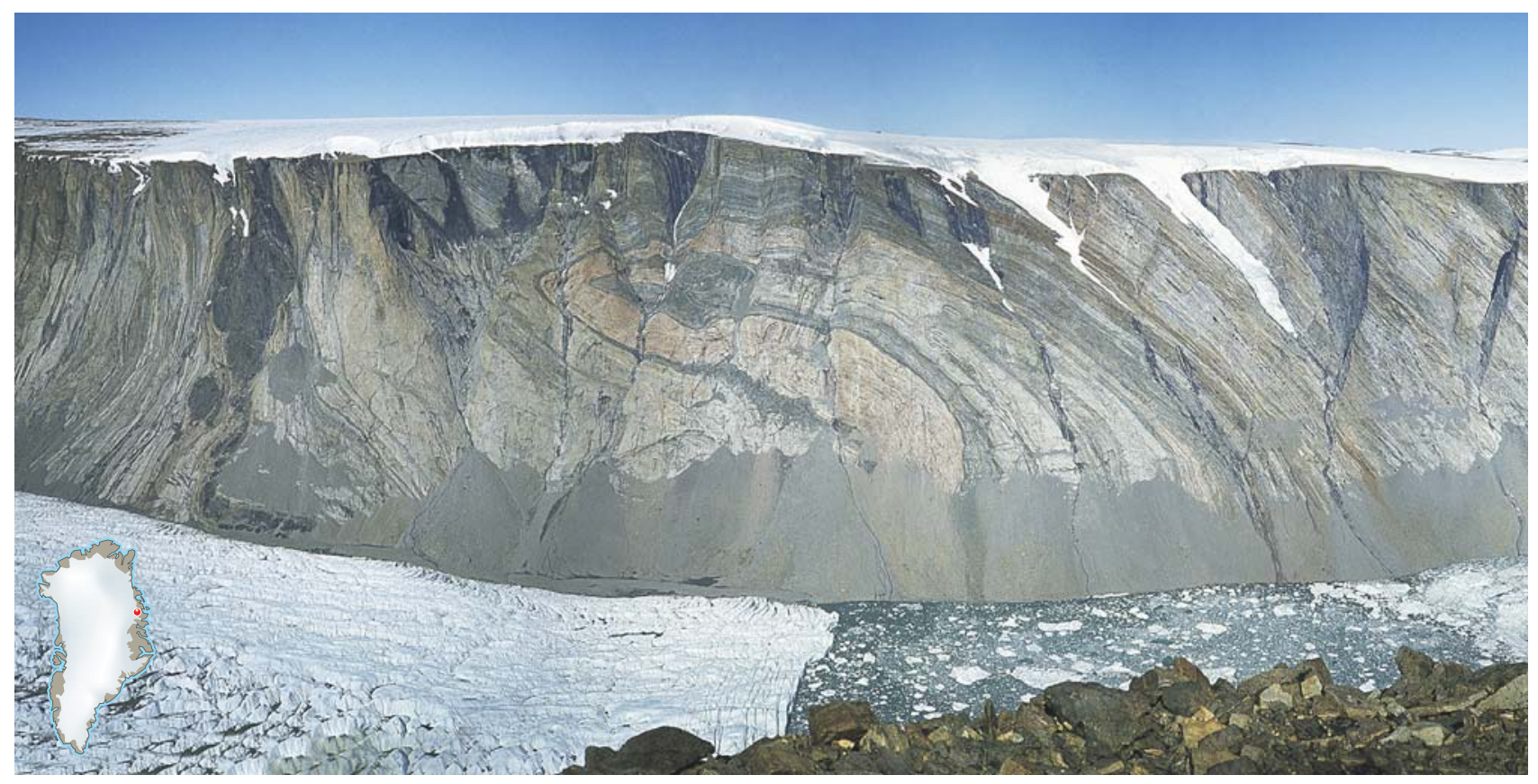

Fig. 34. Major isoclinal fold in reactivated Palaeoproterozoic grey orthogneisses, comprising units of darker banded gneisses and lighter coloured more homogeneous granitoid rocks. The earlier structures have been refolded by N-S-trending open folds with steeply inclined axial surfaces. North side of innermost Grandjean Fjord $\left(c .75^{\circ} 10^{\prime} \mathrm{N}\right)$, North-East Greenland; $c .40 \mathrm{~km}$ south-west of Ardencaple Fjord. The cliff: is approximately $1200 \mathrm{~m}$ high.

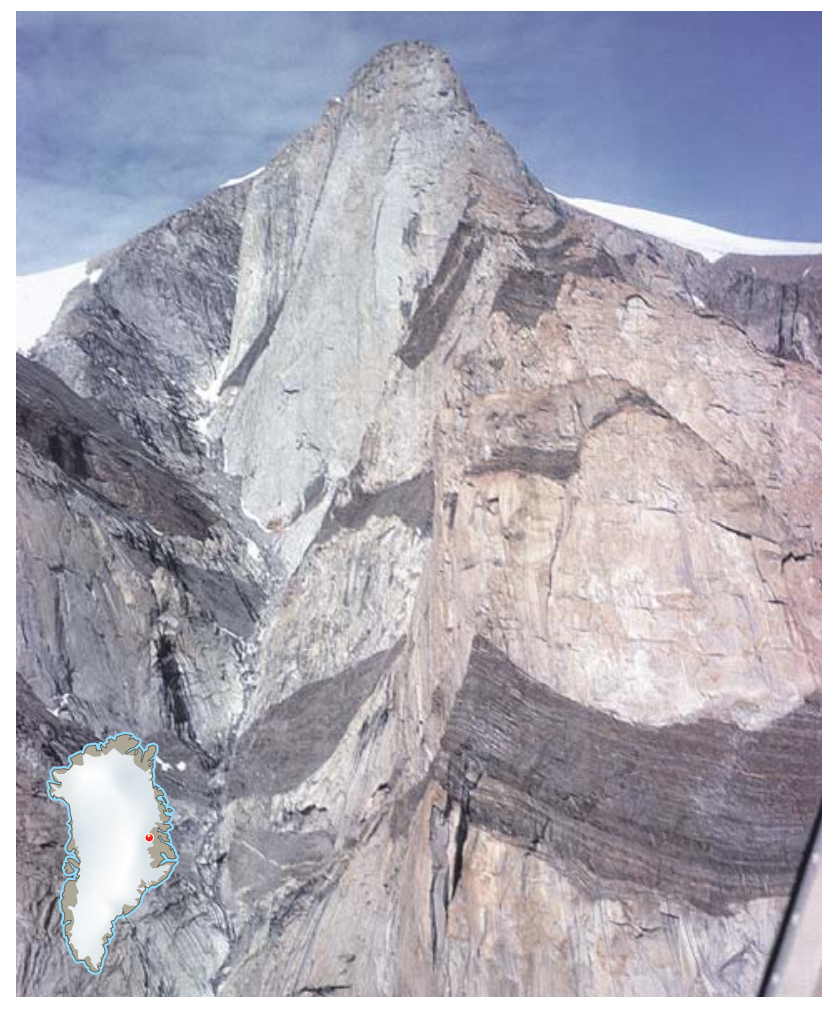

Fig. 35. Caledonian granite with large sedimentary xenoliths of the Neoproterozoic Eleonore Bay Supergroup. East of Petermann Bjerg $\left(c .73^{\circ} \mathrm{N}\right)$, North-East Greenland. Summit about $2100 \mathrm{~m}$ high; upper c. $700 \mathrm{~m}$ of cliff face shown.

\section{Devonian continental sediments in East Greenland}

Following the Caledonian orogeny the extensional collapse of the overthickened crustal welt led to the initiation of Devonian sedimentary basins in central East Greenland (Larsen \& Bengaard 1991; Hartz \& Andresen 1995; Larsen et al. 2008). The Devonian sediments unconformably overlie Ordovician and older rocks, and the deposits were accommodated by SE-NW-oriented dip-slip faulting and are preserved in $\mathrm{N}-\mathrm{S}$-trending graben-like structures.

The basin fill is of Middle and Late Devonian age [39] and consists of more than $8 \mathrm{~km}$ of mainly coarse continental siliciclastic sediments with some volcanic intervals. Four lithostratigraphic groups have been established, each corresponding to a tectonostratigraphic basin stage (Fig. 36). The stages are separated by unconformities related to tectonic events, which took place both during and after sedimentation (Haller 1971; Olsen \& Larsen 1993). Each basin stage is composed of several depositional complexes and shows approximately similar drainage patterns, with deposition mainly from the west and north. The earliest deposits (Vilddal Group, up to $2500 \mathrm{~m}$ thick) are interpreted as laid down by eastwards draining gravelly braided rivers and sandy and silty allu- 


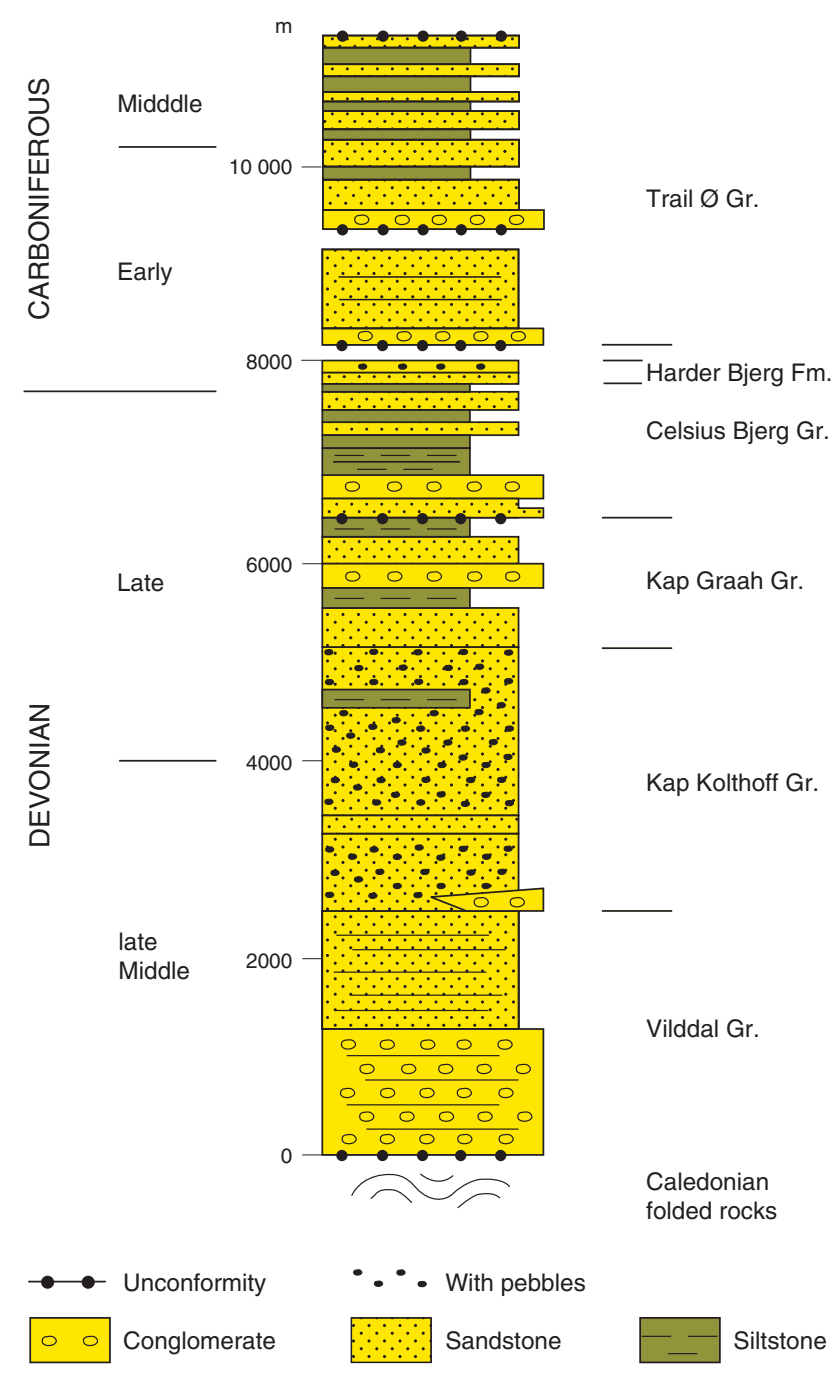

Fig. 36. Schematic, lithostratigraphic composite section of Devonian - Lower Permian continental clastic deposits in central East Greenland $\left(71-74^{\circ} 30^{\prime} \mathrm{N}\right)$, units [39] and [38] on the map. Compiled from Olsen \& Larsen (1993), Stemmerik et al. (1993) and P.-H. Larsen et al. (2008).

vial fans, which gave way to meandering streams and flood plains. The overlying sandstones (Kap Kolthoff Group, up to $2700 \mathrm{~m}$ thick) were deposited by extensive coalescing braidplain systems with southward drainage patterns (Olsen \& Larsen 1993; Olsen 1993) dominated by sandy deposits; this group contains intervals of basic and acid volcanic rocks. During the following stage (Kap Graah Group, up to 1300 m thick) sedimentation was dominated by aeolian deposits succeeded by an alluvial and aeolian complex, which was dominated by finegrained sandstones and siltstones. The following stage (Celsius Bjerg Group, $1550 \mathrm{~m}$ thick) is characterised by northwards drainage patterns. The deposits comprise fluvial sandstones, flood basin sediments and lacustrine siltstone. The uppermost $c .200 \mathrm{~m}$ thick part of the continental Celsius Bjerg stage is now considered early Tournaisian (Carboniferous) in age (Marshall et al. 1999).

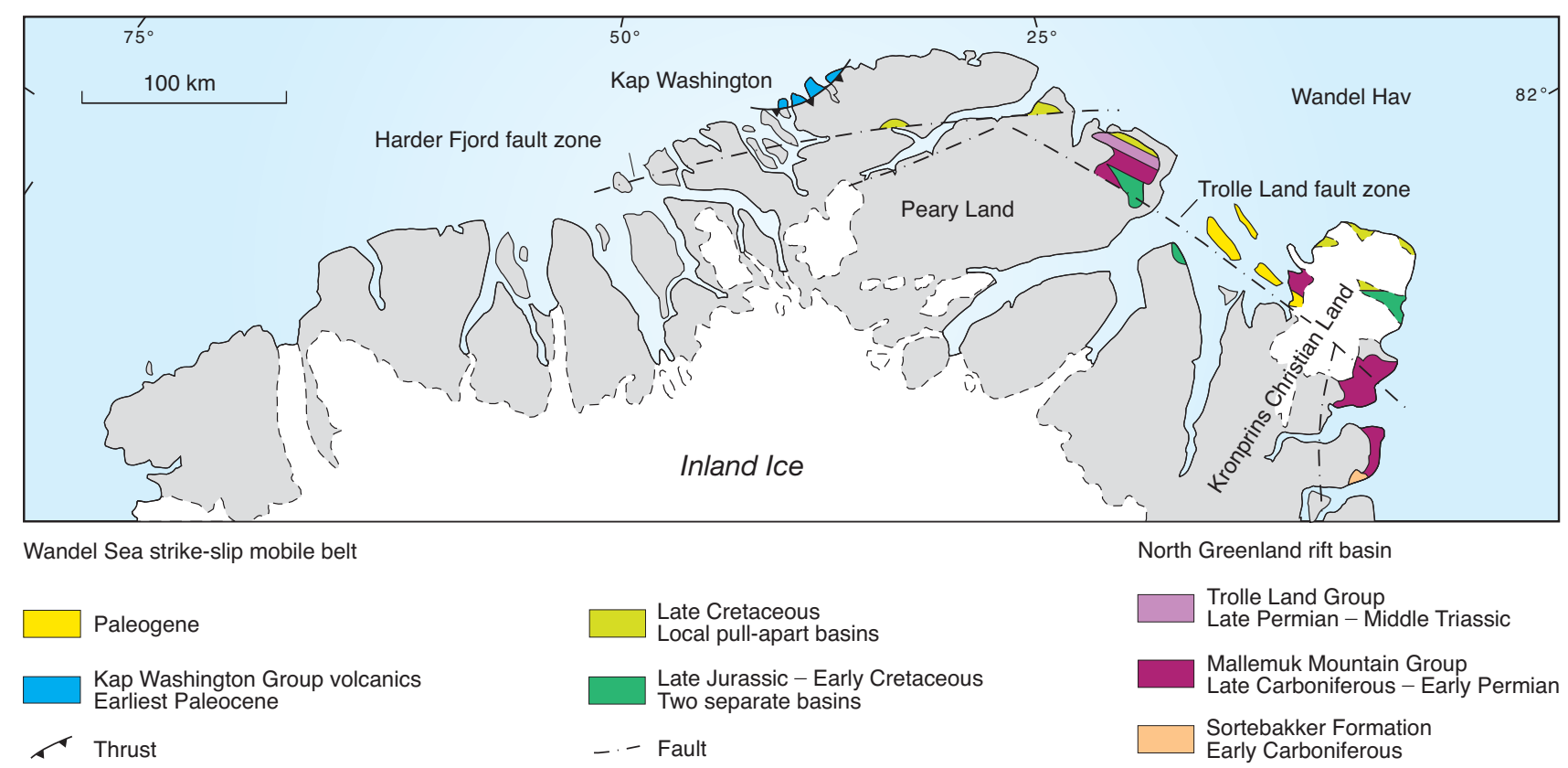

Fig. 37. Distribution of the Wandel Sea Basin sequences in central and eastern North Greenland. Modified from Håkansson et al. (1994). 


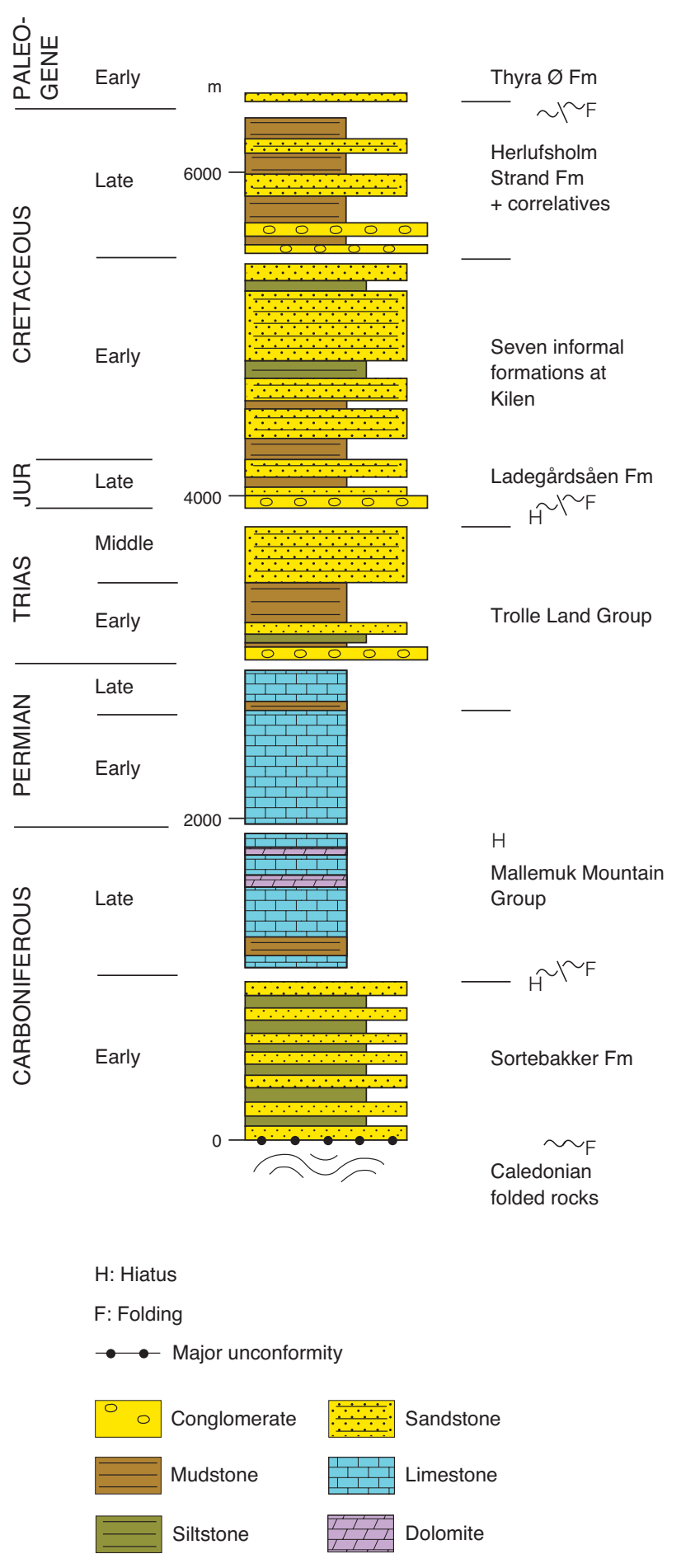

Fig. 38. Composite section of the Wandel Sea Basin successions in eastern North Greenland. The successions occur in several distinct sub-basins. Corresponding units on the map: Sortebakker Formation [20]; Mallemuk Mountain Group [19]; Trolle Land Group [18]; Ladegårdsåen Formation and correlatives [17]; Herlufsholm Strand Formation and correlatives [15]; Thyra Ø Formation [14]. Compiled from Håkansson \& Stemmerik (1989), Stemmerik \& Håkansson (1989) and Stemmerik et al. (2000).

\section{Carboniferous-Tertiary deposits of the Wandel Sea Basin, central and eastern North Greenland}

The Wandel Sea Basin deposits were laid down along the northern and north-eastern margin of the Greenland shield (Figs 37, 38). Three main phases of basin formation are recognised, commencing with a widespread Carboniferous to Triassic event of block faulting and regional subsidence (Stemmerik 2000). Later, during the Late Jurassic and Cretaceous, more localised basin formation took place during two separate events in a strikeslip zone formed at the plate boundary between Greenland and Svalbard (Håkansson \& Stemmerik 1989, 1995).

Lower Carboniferous fluvial deposits (Sortebakker Formation [20]) are restricted to an isolated halfgraben in southern Holm Land $\left(c .80^{\circ} \mathrm{N}\right.$; Stemmerik \& Håkansson 1989, 1991). After mid-Carboniferous regional uplift, rifting started in the late Carboniferous and more than $1100 \mathrm{~m}$ of Upper Carboniferous to Lower Permian shallow marine sediments were deposited (Mallemuk Mountain Group [19]) (Stemmerik et al. 1996, 1998, 2000). The Carboniferous succession is dominated by cyclicly interbedded shelf carbonates (with minor reefs) and siliciclastic rocks. The Lower Permian is mainly represented by shelf carbonates. Renewed subsidence took place during the mid-Permian, and the Upper Permian succession is dominated by alternating shallow marine carbonates and sandstones and deepwater shales. A low-angle unconformity separates these deposits from the overlying Lower and Middle Triassic shelf sandstones and shales (Trolle Land Group [18]) in eastern Peary Land.

Sedimentation resumed in the Late Jurassic, and during the Late Jurassic and Early Cretaceous shelf sandstones and shales (Ladegårdsåen Formation [17]) were deposited in a series of small isolated sub-basins (Håkansson et al. 1991). Following a new episode of strike-slip movements, renewed sedimentation took place in six minor pull-apart basins during the Late Cretaceous. Each basin is characterised by high sedimentation rates, a restricted lateral extent and its location along strike-slip fault zones (Håkansson \& Pedersen 1982; Birkelund \& Håkansson 1983). Depositional environments range from deltaic to fully marine.

At Kap Washington, on the north coast of Greenland, c. $5 \mathrm{~km}$ of extrusive volcanic rocks and volcanogenic sediments (Kap Washington Group [16]) of peralkaline affinity are preserved (Fig. 37; Brown et al. 1987). They are of earliest Paleocene age (64 $\pm 3 \mathrm{Ma}$, Estrada et al. 2001), and their extrusion may be associated with intrusion of a dense swarm of alkali dolerite dykes in North 
Greenland (see Fig. 20). The volcanic rocks are preserved below a major, southward-dipping thrust which transported folded Lower Palaeozoic rocks northwards over the volcanic successions (see Fig. 31).

All pre-Upper Cretaceous deposits in eastern North Greenland were subjected to compressional deformation during the so-called 'Kronprins Christian Land orogeny' (Håkansson et al. 1991). Subsequently to this deformation event a thin succession of upper Paleocene to lower Eocene fluviatile and marine sandstones (Thyra $\varnothing$ Formation [14]) accumulated, which are the youngest deposits of the Wandel Sea Basin succession (Håkansson et al. 1991; Lyck \& Stemmerik 2000).

\section{Late Palaeozoic and Mesozoic rift basins in East Greenland}

A series of Carboniferous-Mesozoic sedimentary basins developed in East Greenland following initial postCaledonian Devonian deposition. The basins formed as $\mathrm{N}-\mathrm{S}$-trending coast-parallel depocentres which reflect prolonged subsidence. Important phases of block faulting and rifting took place during the Early and Late Carboniferous, Late Permian, Late Jurassic and Cretaceous, presaging the opening of the North Atlantic in the late Paleocene (Surlyk 1990, 2003; Stemmerik et al.
1993; Surlyk \& Ineson 2003). There is a marked difference in post-Carboniferous structural style and depositional history between the basins south and north of Kong Oscar Fjord $\left(c .72^{\circ} \mathrm{N}\right)$. The Jameson Land Basin to the south developed as a Late Permian - Mesozoic sag basin, while the region to the north was characterised by continued block faulting and rifting (Fig. 39).

Initial rifting took place during the latest Devonian to earliest Carboniferous, when fluvial sandstones and shales were deposited in narrow half-grabens [38] (Stemmerik et al. 1991). A pronounced hiatus marked by non-deposition and erosion occurred during the midCarboniferous, and active deposition did not resume until the Late Carboniferous when up to $3000 \mathrm{~m}$ of fluvial and lacustrine sediments were deposited in active half-grabens [38]. Deposition ceased sometime during the latest Carboniferous or earliest Permian. During the Early Permian a new episode of regional uplift and erosion took place.

\section{Late Permian - Early Cretaceous deposits of the Jameson Land Basin $\left(70-72^{\circ} \mathrm{N}\right)$}

The Jameson Land Basin contains a stratigraphically complete succession of Upper Permian to earliest Cretaceous sediments (Fig. 40). Sediment infill was derived

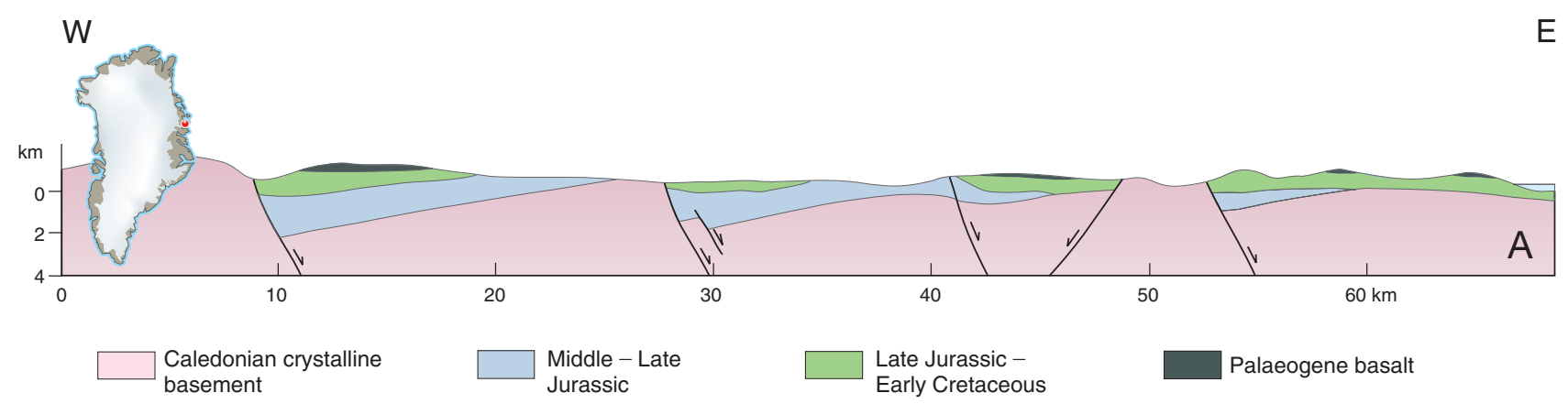

NW

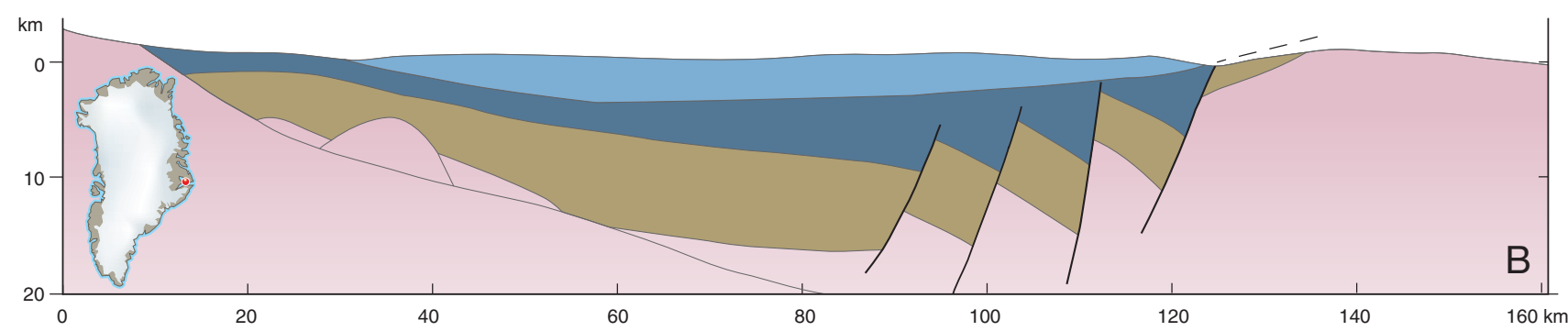

Fig. 39. Upper Palaeozoic - Mesozoic basins in East Greenland. A: Northern development at Wollaston Forland (c. 74º30’N). B: Southern development at Jameson Land $\left(c .71^{\circ} \mathrm{N}\right)$. Note the different scales of the two profiles. From Christiansen $e$ al. (1991) and Surlyk (1991). 


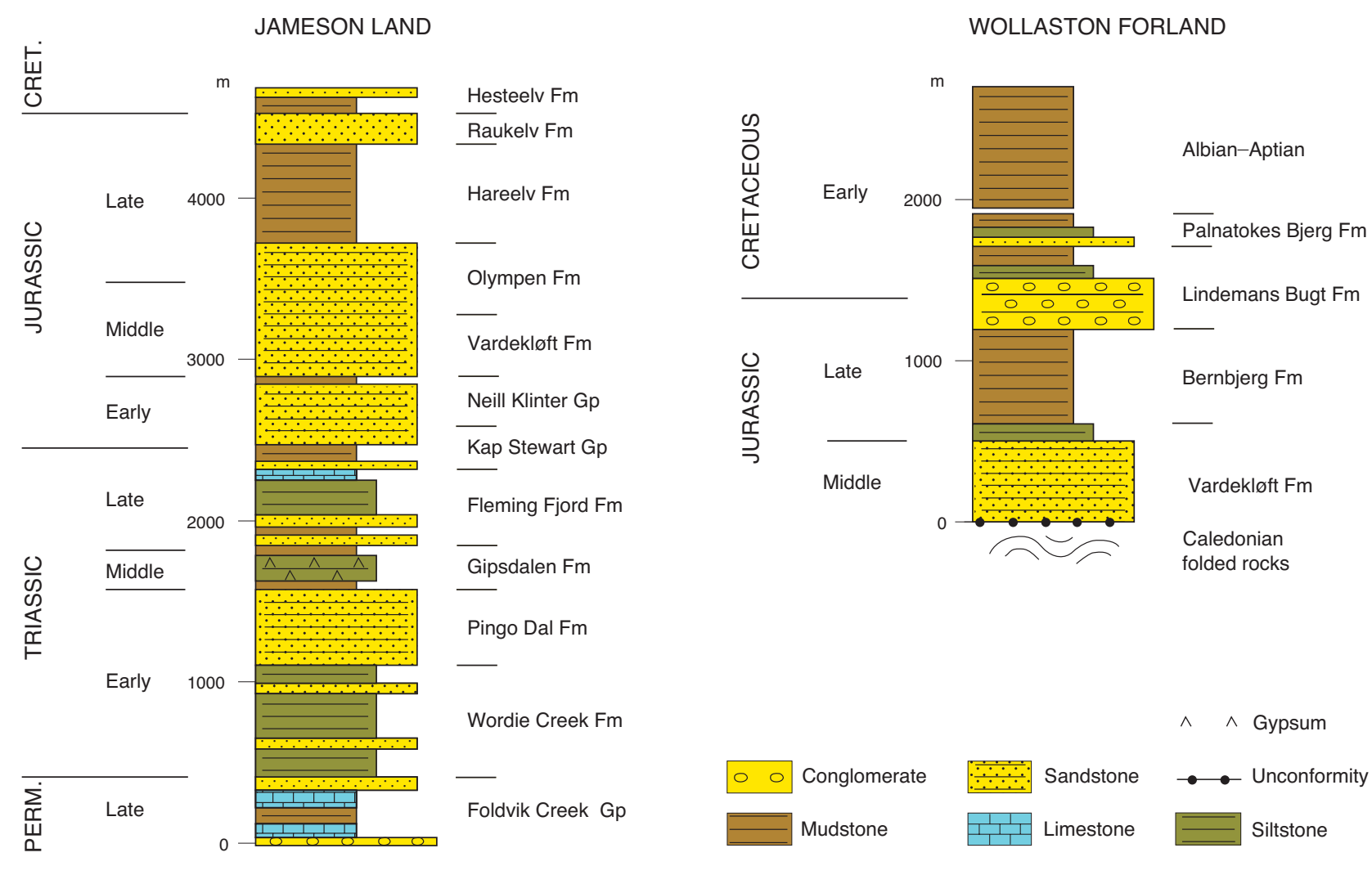

Fig. 40. Schematic sections of the southern (Jameson Land) and northern (Wollaston Forland) developments in the Late Permian and Mesozoic rift margin basins of East Greenland. Corresponding units on the map: Foldvik Creek Group and Wordie Creek Formation [37]; Pingo Dal, Gipsdalen and Fleming Fjord Formations [36]; Kap Stewart Group and Neill Klinter Group [35]; Vardekløft, Olympen, Hareelv and Bernbjerg Formations and correlatives [34]; Raukelv, Hesteelv, Lindemans Bugt and Palnatokes Bjerg Formations and Aptian-Albian sediments [33]. Compiled from: Surlyk \& Clemmensen (1975); Clemmensen (1980b); Surlyk et al. (1981, 1986); Surlyk (1990, 1991); Stemmerik et al. (1993); Dam \& Surlyk (1998). A revised provisional lithostratigraphy of the uppermost Triassic - Jurassic has been proposed by Surlyk (2003).

from both the east and west during most of the basin history. The first marine incursion into the area since the Early Palaeozoic took place during the Late Permian and earliest Triassic with deposition of more than $900 \mathrm{~m}$ of shallow marine sediments [37] (Surlyk et al. 1986). The Permian deposits include alluvial fan conglomerates to marginal marine carbonates and evaporites in the lower part, and carbonate platform to basinal shale deposits in the upper part. The latest Permian and Triassic deposits were dominated by marine sandstones and shales. The next stage in basin development began with deposition of $c .1400 \mathrm{~m}$ of alluvial conglomerates and lacustrine dolomite and shale during the Triassic [36] (Clemmensen 1980a, b).

This Late Palaeozoic - Mesozoic extensional basin in East Greenland contains a succession from uppermost Triassic to Lower Cretaceous, recording at first thermal subsidence, then onset and culmination of rifting, and finally waning of rifting (Surlyk 2003). A major lacustrine basin [35] covered most of Jameson Land during the latest Triassic - earliest Jurassic (Dam \& Surlyk 1993, 1998). Renewed marine incursions took place during the Early Jurassic (Dam \& Surlyk 1998), and during the remaining part of the Jurassic and earliest Cretaceous shelf conditions persisted in the basin (Surlyk 1990). During Middle and Late Jurassic time the basin infill mainly comprised shallow-water sandstones in the northern half of the basin while deeper water shales occur in the southern part [34]. Latest Jurassic and earliest Cretaceous deposits [33] are restricted to the southernmost part of the basin and are dominated by shallow marine sandstones (Surlyk 1991). A revised stratigraphy of the uppermost Triassic to Jurassic has been proposed by Surlyk (2003). 
Late Permian - Cretaceous deposits in North-East Greenland $\left(72-76^{\circ} \mathrm{N}\right)$

The sedimentary succession is stratigraphically less complete in this part of East Greenland due to continuous block faulting during the Mesozoic (Surlyk 1990; Stemmerik et al. 1993). Major hiatuses occur at around the Permian-Triassic boundary and in the Triassic and Early Jurassic.

The Upper Permian and Lower Triassic sediments $[37,36]$ resemble those in Jameson Land; continental Middle Triassic deposits are restricted to the southernmost part of the region. The Middle to Upper Jurassic sediments [34] also resemble those in Jameson Land (Fig. 40), but were deposited in a separate basin (Surlyk 1977). Renewed rifting disrupted the northern part of the region into a series of $10-40 \mathrm{~km}$ wide half-grabens during the latest Jurassic and earliest Cretaceous (Surlyk 1978). These were infilled with more than $3000 \mathrm{~m}$ of syn-sedimentary marine breccias and conglomerates that pass laterally into sandstones and shales. The younger Cretaceous sediments (upper part of [33]) were deposited in a less active rift setting and are dominated by sandy shales with minor conglomerates.

\section{Cretaceous-Palaeogene deposits Central West Greenland}

Cretaceous-Palaeogene sedimentary rocks [8] crop out in the Disko-Svartenhuk Halvø region $\left(69-72^{\circ} \mathrm{N}\right)$ of West Greenland, where they are overlain by Palaeogene basalts (Pedersen et al. 2006). The sediments were laid down in the Nuussuaq Basin and are referred to as the Nuussuaq Group. Although now bounded to the east by an extensional fault system, the sediments may originally have extended both east and south of their present area of outcrop (Chalmers et al. 1999). A single seismic reflection line acquired on the south coast of Nuussuaq c. $25 \mathrm{~km}$ west of locality 2 in Fig. 41 suggests that there are at least $6 \mathrm{~km}$, and perhaps as much as $8 \mathrm{~km}$, of Mesozoic sedimentary rocks below sea level at this locality (Christiansen et al. 1995; Chalmers et al. 1999), but the age and character of the deepest deposits are not known. The following notes are drawn largely from a new comprehensive description of the entire succession of exposed and drilled sedimentary rocks in the basin (Dam et al. 2009).

The oldest sedimentary rocks exposed in the Nuussuaq Basin belong to the Kome Formation of Albian age (column and locality 4 in Fig. 41). These were deposited during a syn-rift phase and crop out on north-east Nuus- suaq where they lie directly on weathered Precambrian basement. The coarse sandstones, mudstones and sparse coal of the Kome Formation reflect an environment dominated by fluvial channels, flood plains and fan deltas amid basement highs. The Slibestensfjeldet Formation that overlies the Kome Formation on north-eastern Nuussuaq is up to $240 \mathrm{~m}$ thick and was deposited in an extensive lake.

In latest Albian to Early Campanian time the southeastern part of the Nuussuaq Basin was the site of a major fluvio-deltaic system that fanned out to the west and north-west from a point somewhere east of the island of Disko/Qeqertarsuaq, reaching deeper water at a shelf edge situated approximately at the position of the N-Strending fault system crossing Disko and Nuussuaq that is shown in the inset map in Fig. 41. The deposits of this system constitute the Atane Formation which is at least $3000 \mathrm{~m}$ thick in the Vaigat area, although the thickest exposed sections are only up to $800 \mathrm{~m}$ thick. In the south-east, sandstones alternating with mudstones, coal seams and heteroliths represent the deposits of a braided river plain while farther north-west (e.g. at locality 2 in Fig. 41) the formation consists of stacked, typical deltaic, coarsening-upward successions (Fig. 42).

The coeval deep marine sedimentary rocks on western Nuussuaq and eastern Svartenhuk Halvø are referred to the Itilli Formation which comprises slope mudstone, turbidite sandstone and conglomerate units (Dam \& Sønderholm 1994). On Svartenhuk Halvø the formation is dominated by mudstone intercalated with thin beds of sandstone interpreted as distal turbidites (Dam 1997). The slope deposits of the Itilli Formation were also penetrated in the GRO\#3 exploration well on western Nuussuaq (locality 1, Fig. 41) that terminated drilling at $3 \mathrm{~km}$ depth. The thickness of the Itilli Formation is estimated to be at least $2000 \mathrm{~m}$ on western Nuussuaq and at least $1000 \mathrm{~m}$ in eastern Svartenhuk Halvø (Dam et al. 2009).

In the Early Campanian the region again became tectonically unstable (Dam et al. 2000). Phases of blockfaulting and uplift were followed by incision of both submarine and subaerial canyons into the underlying deposits (Fig. 42). Conglomerates, turbiditic and fluvial sands and mudstones of Maastrichtian to Danian age (Kangilia, Quikavsak and Agatdal Formations) were deposited mainly in valleys and submarine canyons and consequently vary considerably in thickness (Dam \& Sønderholm 1994, 1998; Dam 2002; Dam et al. 1998, 2009). The Kangilia Formation varies in thickness from $440 \mathrm{~m}$ where it is thickest (locality 3, Fig. 41) to only $75 \mathrm{~m}$ on central Nuussuaq. The Quikavsak and Agatdal 


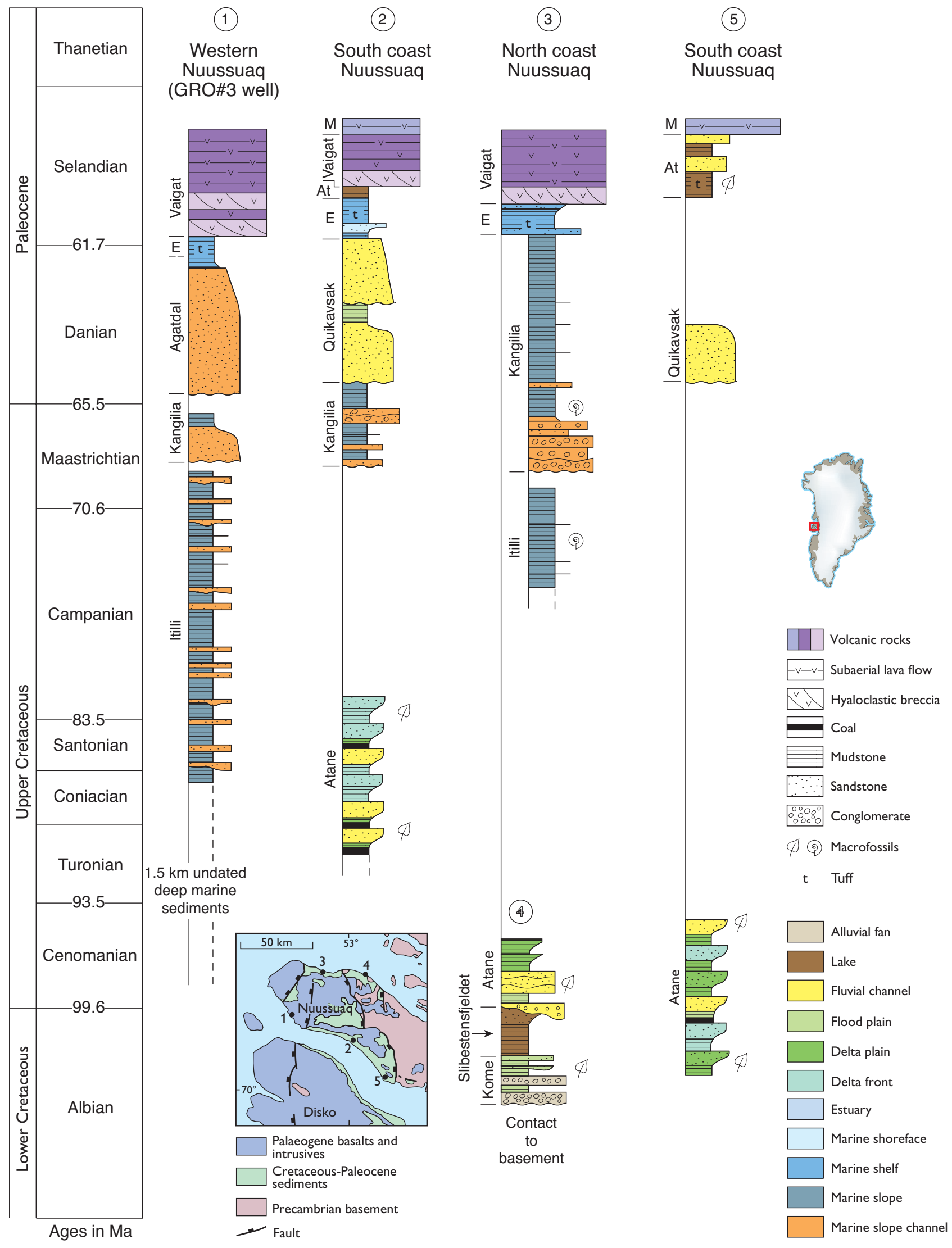

Fig. 41. Lithostratigraphic sections in the Nuussuaq Basin, Disko-Nuussuaq region, central West Greenland (from Dam et al. 2009). The names of the formations are shown to the left of the simplified logs which indicate the main lithologies and depositional environments. M: Maligât Formation (belongs to the overlying West Greenland Basalt Group); At: Atanikerluk Formation; E: Eqalulik Formation. Locations of the sections are shown in the index map. 
Fig. 42. Major submarine canyon incised in Middle Turonian to Late? Santonian sediments (Atane Formation, AF) and infilled with Late Maastrichtian and Early Danian turbidites (Kangilia Formation, KF). Thickness of the well-exposed part of the section is approximately $250 \mathrm{~m}$. Note the coarsening-upwards cyclicity in the Atane Formation sediments. Pale sandstones of the Danian Quikavsak Formation (QF) can be seen high up on the ridge. The highest rocks exposed are hyaloclastic breccias of the Vaigat Formation (VF); a dyke is marked d. Summit of the ridge is $920 \mathrm{~m}$ a.s.l. Locality: Ataata Kuua (locality 2 in Fig. 41).

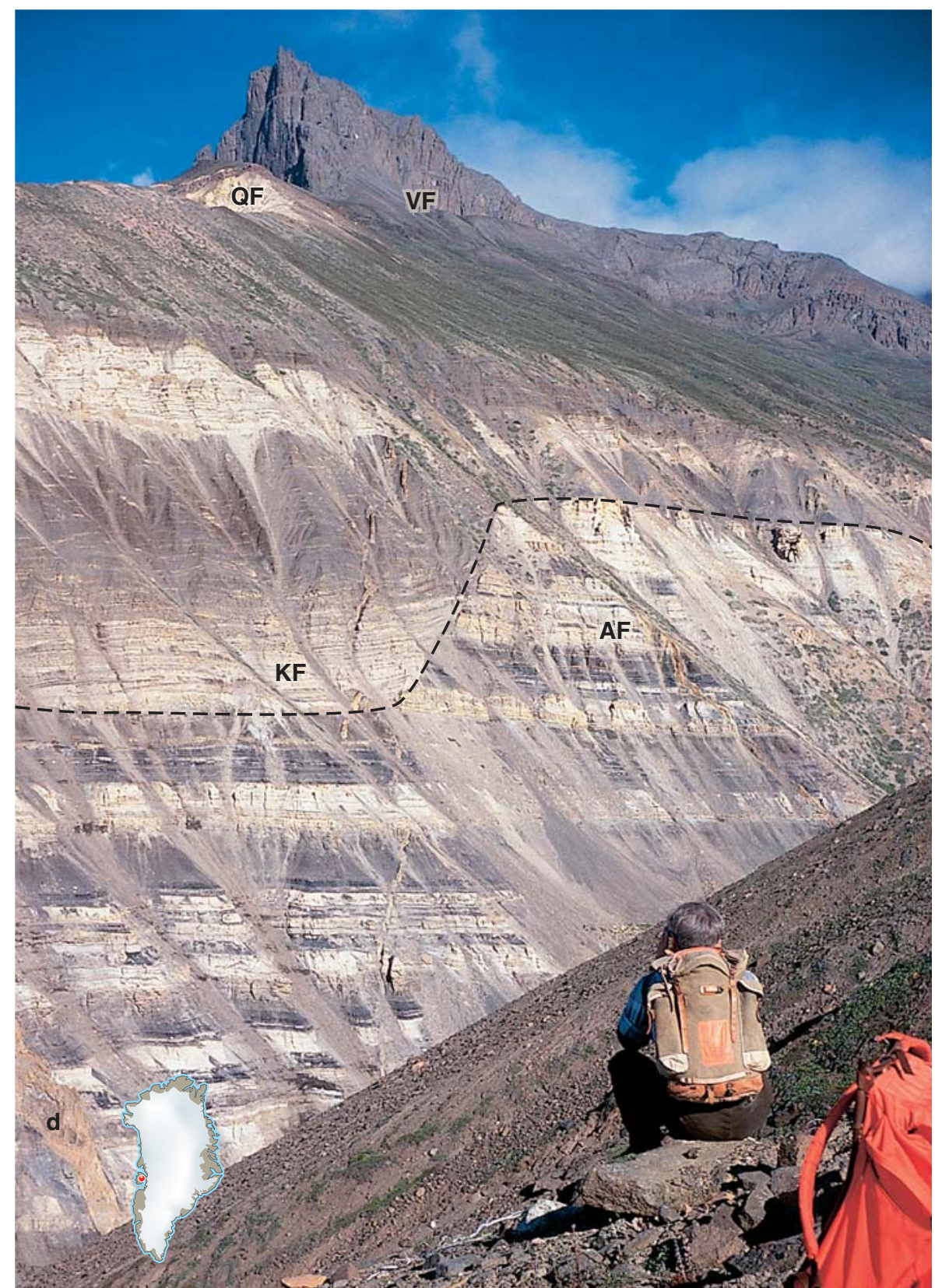

Formations are time-equivalents, the former being fluvial-estuarine and the latter marine. The thickness of the entirely channelised Quikavsak Formation varies from zero to $180 \mathrm{~m}$, while the Agatdal Formation is $18-65 \mathrm{~m}$ thick on central Nuussuaq but $c .250 \mathrm{~m}$ thick in the GRO\#3 well. On central Nuussuaq some units in the Agatdal Formation are extremely rich in redeposited marine fossils, mainly gastropods and bivalves.

The marine mudstones of the Eqalulik Formation that overlie the formations mentioned before are locally interspersed with volcaniclastic sandstones and tuffs, thus recording the earliest evidence of volcanic activity within the sedimentary section of the Nuussuaq Basin. The thickness of the Eqalulik Formation varies from $12 \mathrm{~m}$ to more than $200 \mathrm{~m}$.

The youngest deposits (Atanikerluk Formation) in the Nuussuaq Basin were deposited in lakes in the eastern part of the basin when basalts in the form of hyaloclastite 'deltas' overlain by subaerial lava flows prograded from the west and dammed up a large body of standing water fed by fluvial run-off (G.K. Pedersen et al. 1998; A.K. Pedersen $e t a l$. 2007). The deposits that filled the lakes are arranged in two coarsening-upward successions beginning with lacustrine mudstones and passing 
up into lacustrine-fluvial sandstones. The cumulative thickness of the deposits is $c .500 \mathrm{~m}$, the thickest single section $(c .400 \mathrm{~m})$ occurring on eastern Disko.

\section{Southern East Greenland}

A c. $1 \mathrm{~km}$ thick Cretaceous to Palaeogene sedimentary succession [50] occurs in East Greenland in the Kangerlussuaq Basin north-west of Nansen Fjord $\left(68^{\circ} 17^{\prime} \mathrm{N}\right)$. The sediments onlap crystalline basement to the east and north, but elsewhere the base of the succession is not seen. The sedimentary rocks belong to the Kangerdlugssuaq and Blosseville Groups (Soper et al. 1976; Nielsen et al. 1981). The oldest exposed deposits are fluvial and estuarine sandstones of Late Aptian - Early Albian age. They are overlain by Upper Cretaceous offshore marine mudstones interbedded with thin turbiditic sandstones. In the early Paleocene sediment input increased and submarine fan sandstones were deposited along the northern basin margin whereas mudstone deposition continued within the basin. The offshore marine succession is unconformably overlain by fluvial sheet sandstones and conglomerates of latest Paleocene age (M. Larsen et al. 1999, 2001, 2006). The succession records a basin history of mid-Cretaceous transgression and Late Cretaceous - early Paleocene highstand followed by extensive uplift and basin-wide erosion in the mid-Paleocene. The uplift was quickly followed by renewed subsidence and the onset of extensive volcanism.

\section{Tertiary volcanics, intrusions and post-basaltic sedimentary rocks}

The Palaeogene lava regions of both West and East Greenland represent major eruption sites at the edges of the continent, from which lavas spilled over Mesozoic early Paleocene sedimentary basins and lapped onto the Precambrian basement of the continental interior. The volcanic products were formed during the initial phase of continental break-up and initiation of sea-floor spreading in the early Palaeogene.

\section{Palaeogene basalts, central West Greenland}

Palaeogene volcanic rocks crop out in central West Greenland between latitudes $c .69^{\circ}$ and $73^{\circ} \mathrm{N}$. They are noted for the presence of native iron-bearing basalts and large volumes of high-temperature picrites and olivine basalts
(Clarke \& Pedersen 1976; L.M. Larsen \& Pedersen 2009). The composite stratigraphic thickness of the succession varies between 4 and $10 \mathrm{~km}$, with the smallest thickness on Disko and a maximum on Ubekendt Ejland/Illorsuit $\left(71^{\circ} \mathrm{N}\right)$.

Eruption of the basalts began in a submarine environment, and the earliest basalts, which occur to the west (Fig. 41), consist of hyaloclastite breccias. When the growing volcanic pile became emergent, thin subaerial pahoehoe lava flows started to form. They flowed eastwards into a deep marine embayment where they became transformed into hyaloclastite breccias that prograded eastwards in large-scale Gilbert-type deltas with foresets up to $700 \mathrm{~m}$ high (Pedersen $e t$ al. 1993). Blocking of the outlet caused the marine embayment to be transformed into a lake, which was ultimately filled in with volcanic rocks (A.K. Pedersen et al. 1996; G.K. Pedersen et al. 1998) so that subsequent lava flows lapped onto Precambrian crystalline basement highs in the east.

The lower part of the succession (Vaigat Formation) consists almost entirely of tholeiitic picrites and olivinephyric to aphyric magnesian basalts [7] (Pedersen 1985a). The upper part of the succession (Maligât Formation) consists of tholeiitic, plagioclase-phyric basalts [6] which formed thick plateau lava flows of aa-type. Both the Vaigat and Maligât Formations contain sediment-contaminated units of magnesian andesite and, in the Maligât Formation, also dacite and rhyolite, mostly as tuffs (e.g. Pedersen 1985b). Some of the sediment-contaminated rocks in both formations contain graphite and native iron, formed by reaction with coal and organic-rich mudstones. The succession is mostly flat lying, but is cut by coast-parallel faults in the western part where the lavas dip at up to $40^{\circ}$ westwards.

On Svartenhuk Halvø the upper part of the succession is named the Svartenhuk Formation, which is the stratigraphic equivalent to the Maligât Formation (J.G. Larsen \& Pulvertaft 2000). This area is characterised by extensional faulting and tilting, which together with flexure zones locally give rise to dips of up to $60^{\circ}$ to the south-west.

The major part of the volcanic pile was erupted in a short time span 62-60 Ma ago. On western Nuussuaq and Svartenhuk Halvø there is a younger group of lavas dated at $c .55 \mathrm{Ma}$ (recognised after the map was printed) which also occurs on Ubekendt Ejland (Storey et al. 1998). 


\section{Palaeogene basalts, East Greenland}

Early Palaeogene volcanic rocks crop out in East Greenland between latitudes $68^{\circ}$ and $c .75^{\circ} \mathrm{N}$. South of Scoresby Sund/Kangertittivaq $\left(c .70^{\circ} \mathrm{N}\right)$ plateau basalts cover an extensive region of $c .65000 \mathrm{~km}^{2}$, resting on Mesozoic-Paleocene sediments in the east and south, and on Caledonian and Precambrian gneisses in the west (Nielsen et al. 1981; L.M. Larsen et al. 1989). North of Scoresby Sund Palaeogene basic sills and dykes are widespread in the Mesozoic strata, and a further sequence of plateau basalts is found between latitudes $73^{\circ}$ and $75^{\circ} \mathrm{N}$.

\section{Blosseville Kyst region $\left(68-70^{\circ} \mathrm{N}\right)$}

The earliest Palaeogene volcanics are 61-58 Ma old (Storey et al. 2007). They comprise a $c .1 .8-2.5 \mathrm{~km}$ thick succession of tholeiitic basalts with subordinate picrite [49], which occurs in the southernmost part of the volcanic province between $68^{\circ}$ and $68^{\circ} 30^{\prime} \mathrm{N}$ (Nielsen et al. 1981). The basalts are aphyric or olivine-pyroxene-phyric, and the succession consists of intercalated subaerial flows, hyaloclastites, tuffs and sediments. It is interpreted as the infill of a shallow, partly marine, basin with a source area to the south, along the present coast or on the shelf.

The main part of the region $68-70^{\circ} \mathrm{N}$ is made up of a thick succession of 56.1-55.0 Ma old tholeiitic plateau basalts [48] formed by 5-50 m thick subaerial flows of plagioclase-phyric to aphyric basalt (L.M. Larsen et al.
1989, 1999; Pedersen et al. 1997; Storey et al. 2007). The succession is at least $5.5 \mathrm{~km}$ thick in the central Blosseville Kyst area and thins inland and to the north to $2-3 \mathrm{~km}$ (Fig. 43). Four formations can be followed over almost the whole area and represent two major volcanic episodes. Eruptions took place over the entire area, but accumulation was largest in the coastal areas where the lava pile sagged during deposition. The subsidence accelerated with time, suggesting increased focusing of the magmas into a developing rift zone beyond the present coast.

Along the present coast the lava flows dip seawards at $10-50^{\circ}$ due to later flexing and faulting (Nielsen \& Brooks 1981; Pedersen et al. 1997). Intense injection of coast-parallel dykes occurred in several episodes (Nielsen 1978; L.M. Larsen et al. 1989).

Younger alkali basalt lavas cap the plateau basalts in some small inland areas; one of these occurrences is of Miocene age (13-14 Ma; Storey et al. 1996).

\section{Hold with Hope to Shannon region $\left(73-75^{\circ} \mathrm{N}\right)$}

A succession of $c$. $600-800 \mathrm{~m}$ of plateau basalts [32] occurs in the Hold with Hope to Shannon region in a block-faulted area. The succession is divided into a lower part of uniform tholeiitic lavas and an upper part with variable tholeiitic and alkali basaltic lavas (Upton et al. 1984, 1995; Watt 1994). Between the two there are local occurrences of intervolcanic conglomerates. The basalts on Shannon and the Pendulum Øer, north-east of Wol-

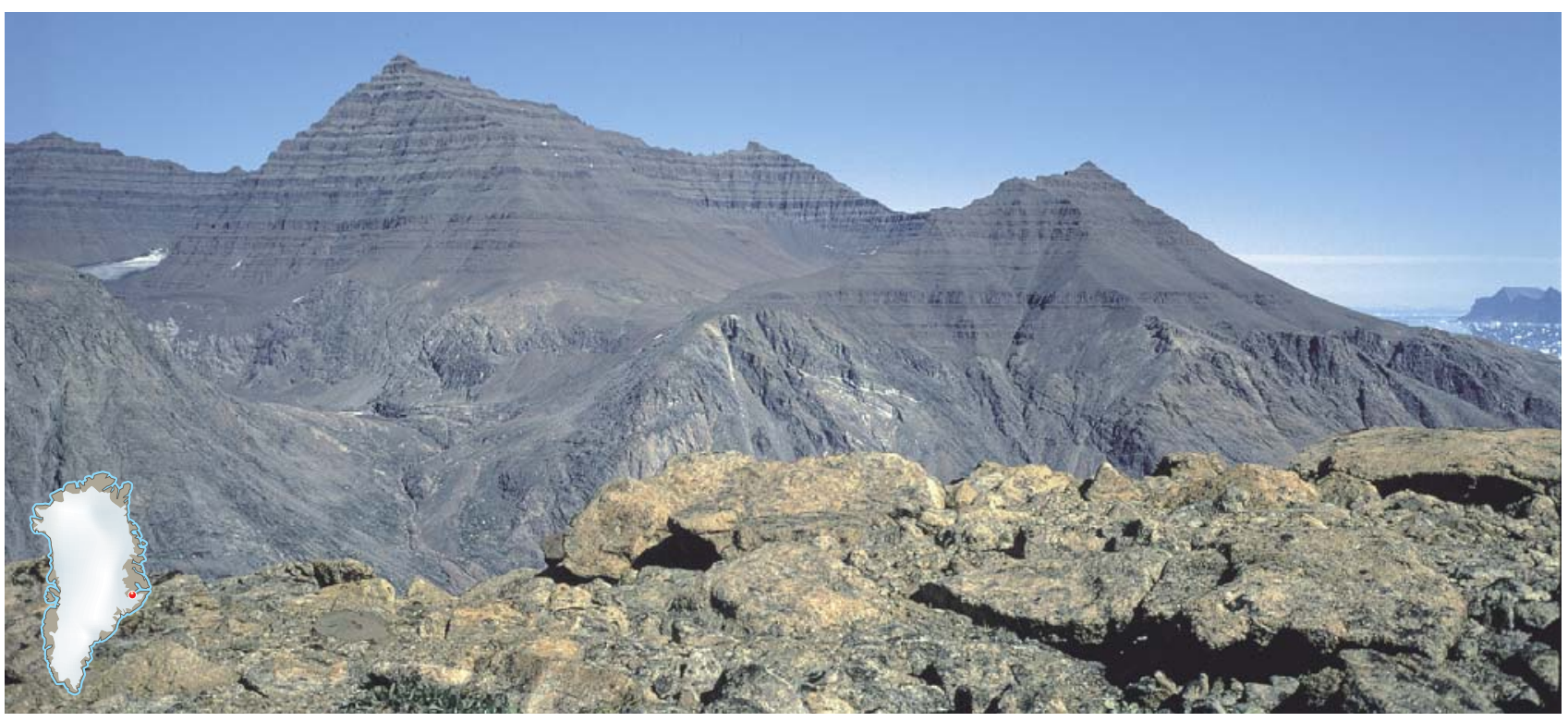

Fig. 43. Major unconformity between Precambrian gneisses deformed during the Caledonian orogeny [52] and Palaeogene plateau basalts [32]. The basalt section shown is approximately $800 \mathrm{~m}$ thick. North of Gåsefjord/Nertiit Kangersivat $\left(c .70^{\circ} \mathrm{N}\right)$, Scoresby Sund region, central East Greenland. Photo: W.S. Watt. 
laston Forland, mainly occur as voluminous sills. The reduced magnitude of volcanic activity in this northerly area, compared to the region south of Scoresby Sund, suggests that it was peripheral to the main volcanic activity in the East Greenland Tertiary volcanic province.

Small areas of basalts with alkaline chemistry occur in the nunatak region $\left(74^{\circ} \mathrm{N}\right)$ where they overlie Caledonian and older crystalline rocks (Katz 1952; Brooks et al. 1979; Bernstein et al. 2000).

\section{Palaeogene intrusions, East Greenland}

Numerous intrusions are exposed along about $1000 \mathrm{~km}$ of the coastal region of East Greenland between latitudes $66^{\circ} 30^{\prime}$ and $74^{\circ} \mathrm{N}$, in addition to the many dykes and sills (see Fig. 20); approximately 20 of these intrusions are shown on the map, separated into felsic [53] and intermediate and mafic [57] types (Fig. 44). They reflect episodes of alkaline magmatism linked to the continental break up of the North Atlantic (Nielsen 1987), and range in age from late Paleocene to Oligocene. The oldest intru-

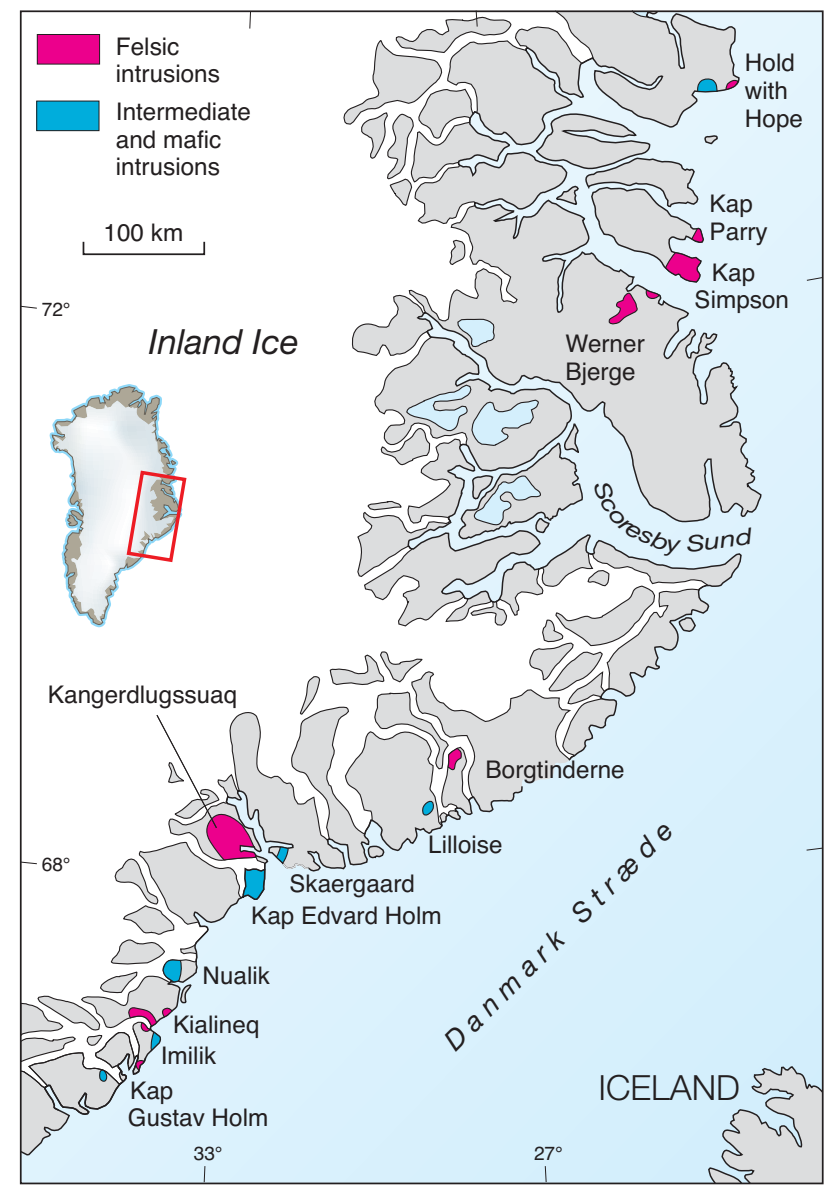

Fig. 44. Major Tertiary intrusive centres in East Greenland ( $c$. $\left.66^{\circ} 30^{\prime}-74^{\circ} \mathrm{N}\right)$. Slightly modified from Nielsen (1987). sions occur in the south, and have ages between 57 and $47 \mathrm{Ma}$. Felsic intrusions in the south are 35-37 Ma old, whereas the more northerly intrusions $\left(72-74^{\circ} \mathrm{N}\right)$ have ages in the range 48-25 Ma (Tegner et al. 1998, 2008; Brooks et al. 2004).

Petrologically the intrusions can be divided into three groups (Nielsen 1987): (A) alkaline inland intrusions; (B) alkaline dyke swarms and (C) syenitic to granitic complexes and dykes. Most of the numerous intrusions found along the coast belong to the third group; they are central intrusions and intrusive complexes, often with several rock types within the same complex. They range from a few square kilometres to $c .850 \mathrm{~km}^{2}$ in size. The felsic complexes [53] are dominated by alkali granites, quartz syenites, syenites and nepheline syenites. The mafic to intermediate complexes [57] are dominated by tholeiitic gabbros, whereas subordinate rock types locally include monzonite and alkali gabbro. The $55 \mathrm{Ma}$ old Skaergaard intrusion is a classic example of a layered gabbroic intrusion, and has been studied in great detail (Wager \& Deer 1939; McBirney 1996a, b; Irvine et al. 1998).

\section{Post-basaltic Palaeogene sedimentary rocks, East Greenland}

Post-basaltic sedimentary rocks [47] are preserved in two small, down-faulted areas near the Atlantic coast south of Scoresby Sund (Kap Brewster, c. $70^{\circ} 10^{\prime} \mathrm{N}$ and Kap Dalton, $\left.c .69^{\circ} 25^{\prime} \mathrm{N}\right)$. They comprise a $c .100 \mathrm{~m}$ thick succession of Palaeogene (Middle Eocene, 48-45 Ma old) fluvial to shallow marine sandstones and siltstones (M. Larsen et al. 2005) referred to as the Kap Dalton Group. These post-volcanic deposits have been dated by dinoflagelate cysts and suggest that volcanism in this region came to an end close to the Early-Middle Eocene boundary between 49 and $48 \mathrm{Ma}$.

The Palaeogene sedimentary rocks preserved onshore are marginal exposures of an extensive and much thicker $(5-6 \mathrm{~km})$ Tertiary succession found on the adjacent shelf areas (see p. 75).

\section{Pliocene-Pleistocene sediments, central North Greenland}

The late Pliocene - early Pleistocene Kap København Formation [13] is a $c .100 \mathrm{~m}$ thick succession of unconsolidated sand and silt, which crops out over an area of $c$. $500 \mathrm{~km}^{2}$ in easternmost Peary Land, North Greenland 


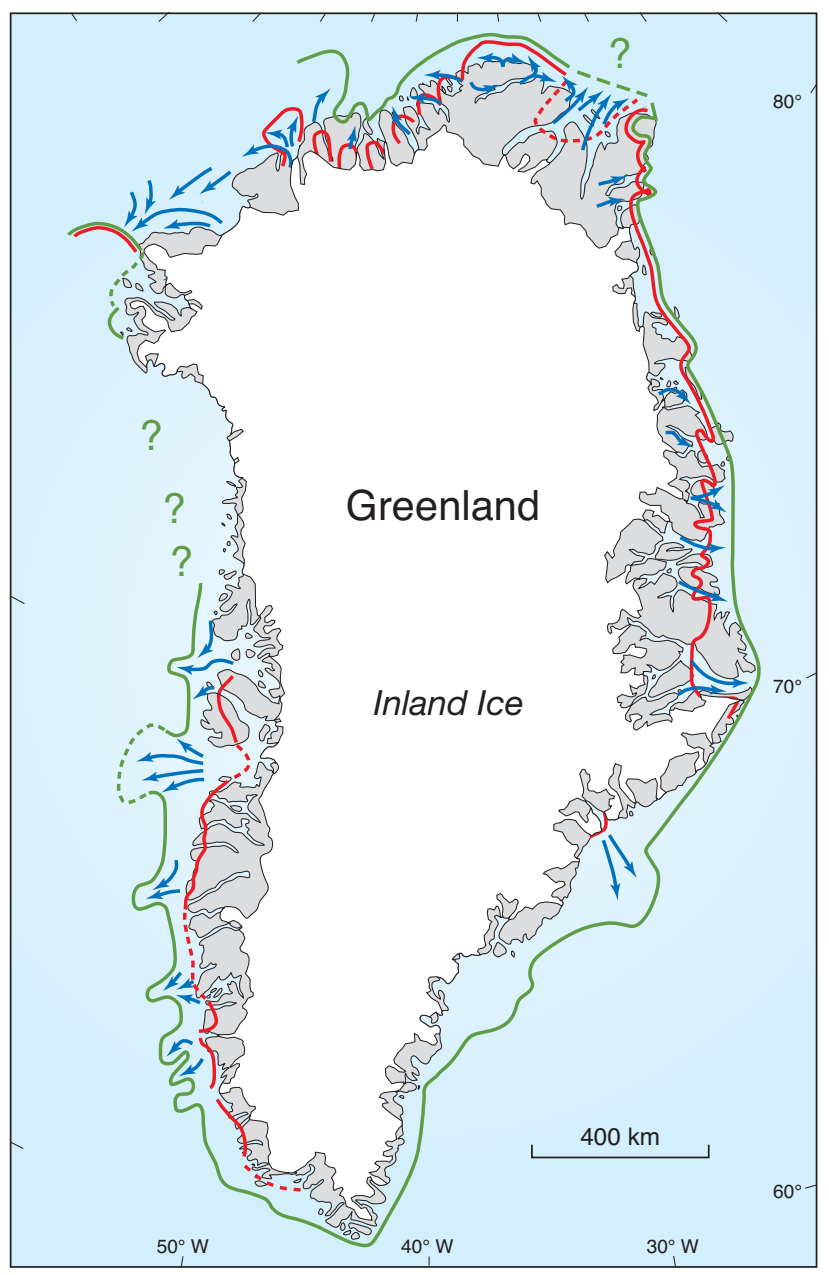

Fig. 45. Former extent of the Greenland Inland Ice during the last glacial maximum. Green: $c .18000$ years before present; red: $c .10000$ years ago; blue arrows: major glacier outlet streams. Modified from Funder \& Hansen (1996).

(Funder \& Hjort 1980; Funder 1989). The succession contains well-preserved faunal and floral elements. The base of the succession is not exposed. The lower $25 \mathrm{~m}$ comprise marine silt containing high Arctic molluscs, whereas the upper sand-dominated part containing tree trunks reflects nearshore environments. The flora and fauna found in this upper unit point to a much warmer climate than the present. The Kap København Formation shows disturbance caused by overriding glaciers during the Quaternary glaciation, and is overlain by till.

\section{Quaternary glacial sediments and glaciation}

During most of the Quaternary Greenland was completely, or almost completely, covered by ice, and glacial deposits are widespread on the present ice-free land areas and on the adjacent shelf (Funder 1989; Funder $e t$ al. 1998). As the map is a bedrock geology map, Quaternary deposits are only shown in regions where a thick cover of Quaternary superficial deposits conceals the bedrock over large areas (valleys, interior plains and some coastal areas). These areas have been shown on the map as undifferentiated Quaternary.

Recent studies indicate that the glaciation of NorthEast Greenland had started as early as the mid-Miocene (14-15 Ma ago; Thiede et al. 2001). Evidence from the shelf areas shows that an early glaciation of Greenland at the end of the Pliocene (c. 2.4 million years ago) was more extensive than any succeeding glaciation, with an ice sheet covering nearly the entire shelf region up to a few hundred kilometres beyond the present coastline (Funder 1989). During this glaciation the land area was subjected to extensive erosion, with much of the eroded material being deposited on the offshore shelves.

The superficial deposits found on the ice-free land areas are dominated by the late Quaternary development of the past c. 130000 years (Saalian/Illinoian-Holocene). The last interglacial period (Eemian/Sangamonian) is recorded in both East and West Greenland. During the late Weichselian/Wisconsinan $c .18000$ years ago the maximum extent of the ice around the northern parts of Greenland was close to the present coastline, whereas in parts of West and South-East Greenland the ice advanced onto the shelf area (Funder \& Hansen 1996; Fig. 45). In South Greenland, modelling of the thickness of the ice cover over the outer coast during the Last Glacial Maximum shows that the ice must have been at least $1500 \mathrm{~m}$ thick (Bennike et al. 2002). Recent studies indicate that the Greenland ice sheet during the late Weichselian/Wisconsinan reached out to the middleouter continental shelf in North-East Greenland, a distance of more than 100-200 km beyond the present coastline (Evans et al. 2009).

The retreat of the Inland Ice after the last glacial period began 14 000-10 000 years ago, and continued with oscillations to a maximum stage of withdrawal approximately 6000 years ago when the ice margin was up to $20 \mathrm{~km}$ inside its present position. The position of the margin of the Inland Ice where it now abuts against land areas only shows minor fluctuations (Fig. 46). Significant changes are almost restricted to major drainage outlets where the Inland Ice flows into fjords to form calving glaciers; the most active glaciers in Greenland have velocities of up to $22 \mathrm{~m}$ per 24 hours. 


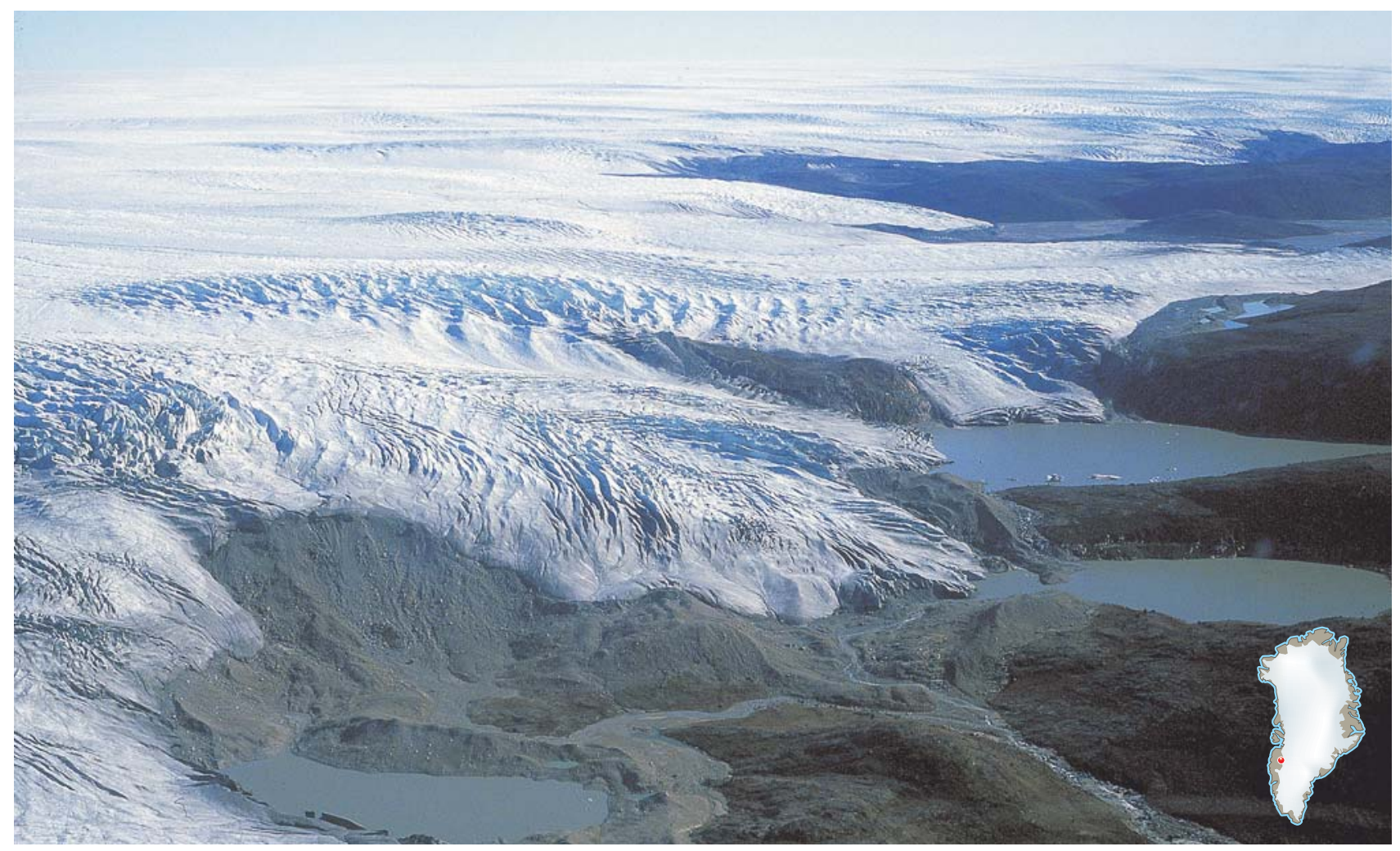

Fig. 46. Characteristic front of the Inland Ice abutting the ice-free land area, with moraines and small lakes. The distance from the bottom of the picture to the land area in the background is approximately $5 \mathrm{~km}$. The locality is about $75 \mathrm{~km}$ north-north-east of Søndre Strømfjord airport, southern West Greenland, at $c .67^{\circ} 30^{\prime} \mathrm{N}$. View is towards south. Photo: H. Højmark Thomsen.

\section{Glaciology}

The present ice cover of Greenland is a relic of the Pleistocene ice ages. It consists of the large continental ice sheet (the Inland Ice), and local ice caps and glaciers (Weidick 1995).

The Inland Ice has an area of $c .1707000 \mathrm{~km}^{2}$ and reaches an altitude of $3230 \mathrm{~m}$ with a maximum thickness of $3420 \mathrm{~m}$. The local ice caps and glaciers cover areas of $c .49000 \mathrm{~km}^{2}$ (Weng 1995). The volume of the Inland Ice has been estimated at $2600000 \mathrm{~km}^{3}$, based on ice thickness measurements by airborne radio-echo sounding; a rough estimate of the volume of local ice caps and glaciers is $20000 \mathrm{~km}^{3}$. On the map, surface contours, isopachs of ice thickness and contours of the bedrock below the Inland Ice are shown.

Mean annual air temperatures on the Inland Ice range from $-30^{\circ} \mathrm{C}$ over a large region in its central and northern parts to about $-5^{\circ} \mathrm{C}$ in its south-western marginal areas. The temperature of the ice ranges between $-32^{\circ}$ and $0^{\circ} \mathrm{C}$; with increasing depth, the temperature generally increases due to geothermal heat flux and internal heating caused by deformation. In some locations, the temperature at the base of the ice sheet may reach its melting point.

\section{Mass balance}

The mass balance (budget) of the Inland Ice is the difference between accumulation (of snow in the interior region mainly) and ablation by melting and calving of icebergs in the marginal areas.

The accumulation of snow decreases from south to north from more than $2000 \mathrm{~mm}$ water equivalent/year in coastal areas in the south-west to $100 \mathrm{~mm}$ water equiv- 
alent/year or less in interior north-eastern areas (Ohmura \& Reeh 1991). Melt rates also decrease from south to north. Away from the coast in South-West Greenland, the annual melting of the ice at sea level probably reaches values near $10000 \mathrm{~mm}$ water equivalent. However, even along the northernmost margins of the Inland Ice significant melting occurs; melt-rate models predict values near $2000 \mathrm{~mm}$ water equivalent/year at sea level. Calving glacier fronts producing icebergs are generally located at the heads of fjords at some distance from the outer coast. The most concentrated source region for icebergs is central West Greenland (Disko Bugt and the area between Nuussuaq and Svartenhuk Halvø) where about $100 \mathrm{~km}^{3}$ of calf ice are produced annually.

The effects of climate change in recent years on the mass balance of the Greenland ice sheet have been documented by satellite gravity measurements. Over the four years 2004-2007 the ice sheet lost an average of $c$. $400-500 \mathrm{~km}^{3}$ in the summer period of each year and only gained c. $250-350 \mathrm{~km}^{3}$ of snow in the winter. The net result is a loss of $c .150 \mathrm{~km}^{3} /$ year from the beginning of the 20th century (Witze 2008), although some researchers estimate even larger figures for the present net loss.

\section{Past climate and environment}

Up to 2009 five deep ice cores have been retrieved by drilling through the Inland Ice (one drilling was only to a depth of $1400 \mathrm{~m}$ ), and these have provided considerable information about climate and environmental variations during the past 150000 years. The ice-core records indicate that in central Greenland the Inland Ice survived the last interglacial (the Eemian) which culminated about 125000 years ago, without completely disappearing even when the climate was several degrees warmer than at present. However, according to icedynamic model calculations of the evolution of the Inland Ice, the ice cover in northern and southern Greenland was less extensive during the Eemian (Fig. 47).

The ice-core records indicate dramatic temperature fluctuations during the last ice age, which lasted from about 115000 years ago to about 11700 years ago. In the coldest parts of this period, temperatures in Greenland may have been $10-12^{\circ} \mathrm{C}$ colder than now, whereas temperatures in other periods of the ice age were only about 5 degrees colder (Dansgaard 1997; Hammer 1997).

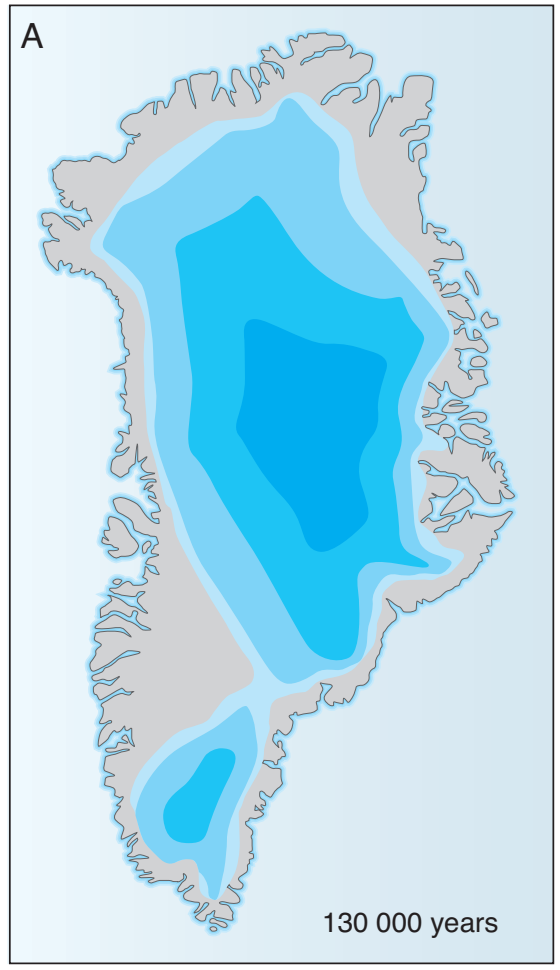

Ice free

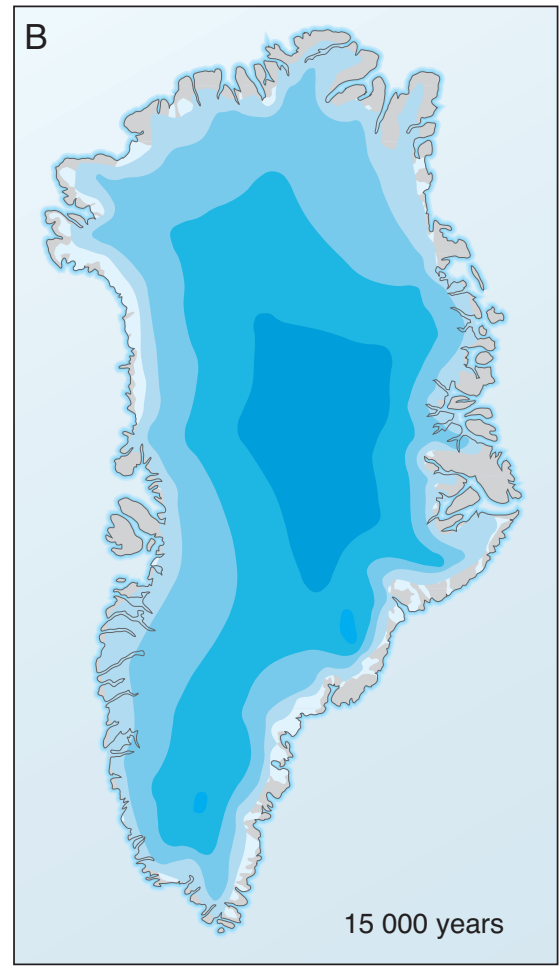

$1000-1600 \mathrm{~m}$

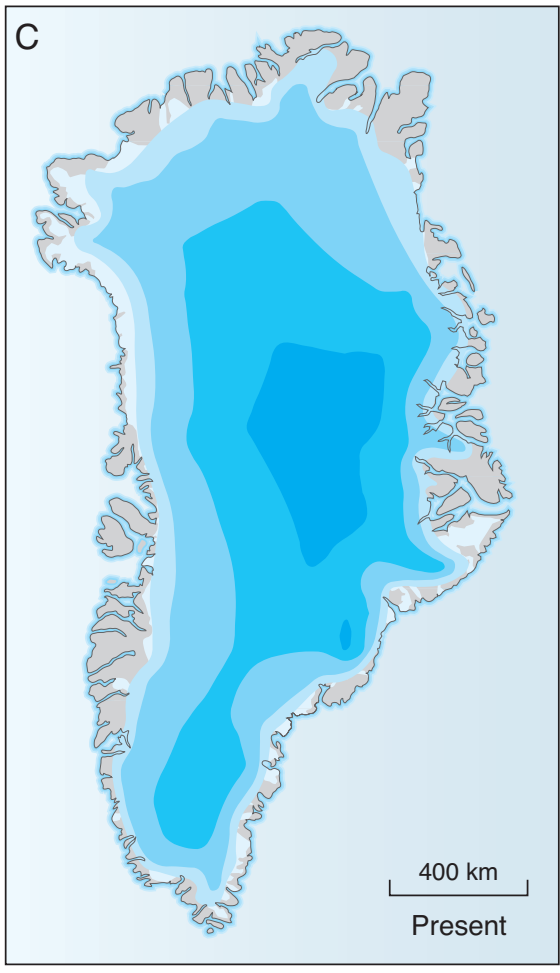

2400-3000 m

$>3000 \mathrm{~m}$

Fig. 47. Models of the Inland Ice with indication of thickness of the ice sheet in metres. A: The last interglacial (the Eemian) with a temperature $4-5^{\circ} \mathrm{C}$ higher than the present. B: During the late glacial maximum (Weichselian) with a temperature $10-12^{\circ} \mathrm{C}$ colder than at present. C: Under the present climatic conditions. From model calculations by Letréguilly et al. (1991). The models do not include the offshore extent of the ice, only that of present land areas. 


\section{Offshore geology}

The interpretation of the offshore geology shown on the 1:2 500000 scale map was based mainly on seismic surveys carried out between 1970 and 1992, supplemented by aeromagnetic and gravimetric data and, in the case of southern West Greenland, by data from five exploration wells drilled in 1976-77. Offshore South-East Greenland six holes were drilled in 1993 at $c .63^{\circ} \mathrm{N}$, constituting Leg 152 of the Ocean Drilling Program (ODP; H.C. Larsen et al. 1994a); the positions of three of these wells are shown on the map. In 1995 three more holes were drilled off South-East Greenland as part of the aborted ODP Leg 163, but no results were available when the map went to press (H.C. Larsen et al. 1996). However, the coverage of geophysical data in different areas was, and still is, uneven, and is dependent on ice conditions. Off southern West Greenland, where there are only scattered icebergs and no pack ice in the late summer and early autumn, more than $37000 \mathrm{~km}$ of seismic data were acquired by the oil industry in the 1970s and a further $10259 \mathrm{~km}$ of non-exclusive data were acquired in this area in the years 1990-1994 (Pulvertaft 1997). In contrast, the often ice-infested areas off East, North-East and North-West Greenland were only covered by reconnaissance surveys, principally as a result of the KANUMAS and North Atlantic D (NAD) surveys. The KANUMAS project was a marine seismic reconnaissance financed by six major oil companies, with the Greenland-Danish national oil company Nunaoil A/S as operator (H.C. Larsen \& Pulvertaft 1990; Pulvertaft 1997). In the 1990s KANUMAS surveys acquired $c .7000 \mathrm{~km}$ of seismic data off North-East and central East Greenland, and c. 4000 $\mathrm{km}$ of data off North-West Greenland; although these data are confidential company data, some results had been released in time to be included in the 1:2 500000 map. The North Atlantic D project was a combined aeromagnetic and seismic survey of the East Greenland shelf carried out by Grønlands Geologiske Undersøgelse (GGU) in 1979-83. During this project $c .8000 \mathrm{~km}$ of seismic data were acquired off central East and SouthEast Greenland (Thorning et al. 1982; H.C. Larsen 1985). In Nares Stræde (Nares Strait) and off North Greenland, where no seismic data existed, interpretation of the geology was based on aeromagnetic and sparse gravity data alone. Aeromagnetic and shipborne magnetic data constituted the main source of information in oceanic areas.
The 1:2 500000 map was designed to show two general aspects of offshore geology: (1) the extent of continental crust $[\mathbf{a}]$, oceanic crust $[\mathbf{c}-\mathbf{g}]$, and of the intervening, poorly understood, transition zone [b] and (2) the distribution of sedimentary basins and major faults. Where extensive volcanic units are known to occur in areas underlain by continental crust, their distribution is also shown.

Since compilation of the 1:2 500000 map a large amount of new data has been acquired in the maritime regions surrounding Greenland, both by the industry and by academic research institutes. It is clear from these data that the map is not correct in many places. In the following text, attention is drawn to the known errors in the map, and as more data are released, there will no doubt be need for further corrections. The distribution of crustal types offshore as now understood (2009) is shown in Fig. 49A, p. 68, while offshore and onshore sedimentary basins are shown in Fig. 56.

\section{The continental margin off East and North Greenland East Greenland south of $77^{\circ} \mathrm{N}$}

In general terms, the continental margin off East Greenland between the southern tip of Greenland and $76^{\circ} \mathrm{N}$ can be described as a volcanic rifted margin (H.C. Larsen 1990; H.C. Larsen et al. 1994a, b), formed when Greenland became separated from northern Europe at the start of sea-floor spreading in early Eocene time (magnetochron 24R). Between $c .68^{\circ} \mathrm{N}$ and the Jan Mayen Fracture Zone, however, Greenland remained attached to the Jan Mayen microcontinent (Fig. 49A, B) until Oligocene time when spreading shifted from the Aegir Ridge to the Kolbeinsey Ridge.

The position of the continent-ocean boundary (COB) was drawn on the basis of aeromagnetic data supplemented by characteristic features in the NAD reflection seismic data. The absolute seawards (eastern) limit of continental crust cannot overlap areas where linear magnetic anomalies characteristic of oceanic crust can be identified with confidence. Along the entire volcanic rifted margin seaward-dipping reflectors can be seen in the seismic data. These arise from subaerial lava flows or groups of flows that were erupted in the early stages of 
sea-floor spreading prior to differential subsidence below sea-level. In connection with the seaward-dipping reflectors, buried volcanic escarpments may occur. These are landward-facing escarpments formed at the landward end of the dipping reflectors, where lava flows interfinger with sedimentary rocks (Fig. 48; H.C. Larsen \& Jakobsdóttir 1988; H.C. Larsen 1990).

The zone off East Greenland shown on the map as underlain by transitional crust $[\mathrm{b}]$ was drawn in a rather arbitrary manner, at least with regards to its width. This zone is thought to consist of attenuated and fragmented continental crust with increasing numbers of dykes and other intrusions as oceanic crust is approached. Much of the onshore coastal area around and south of Kangerlussuaq $\left(68^{\circ} \mathrm{N}\right)$ is very intensely intruded by Palaeogene coast-parallel dyke swarms (Nielsen 1978; Klausen \& Larsen 2002; not shown on the map). Aeromagnetic data indicate that these dyke swarms continue southwestwards under the shelf as far south as $63^{\circ} \mathrm{N}$ (H.C. Larsen 1978). This intensity of dyke intrusion suggests the proximity of the continent-ocean boundary, i.e. the outer edge of the transition zone.

Since the map was printed, results of intensive research carried out off southern East Greenland along Leg 152 of the Ocean Drilling Program (ODP sites 914-919, c. $63^{\circ} \mathrm{N}$ ) have been published (H.C. Larsen \& Saunders 1998; H.C. Larsen et al. 1998). Results of this research indicate that the continent-ocean boundary, defined here as the point at which thinned, intensely dyked continental crust finally gives way to a sheeted dyke complex, is situated in this area about $12 \mathrm{~km}$ landwards of the shelf break (H.C. Larsen \& Saunders 1998 fig. 12). The shelf break here is the edge of a thick prograding wedge of glaciomarine sediments. The inner boundary of the continent-ocean transition zone, i.e. the point at which extensional faulting intensifies and marked atten-

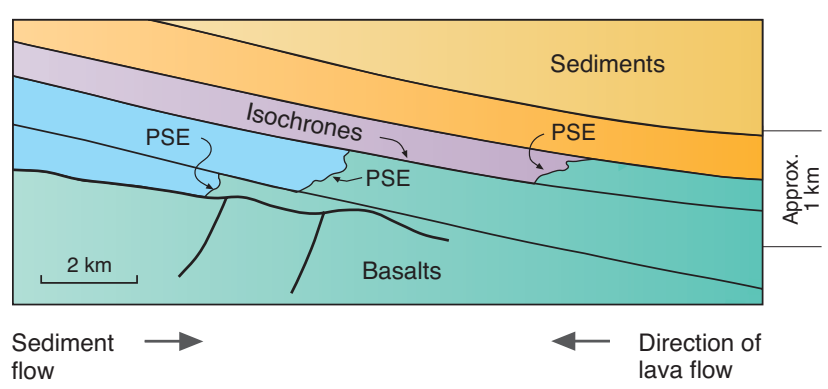

Fig. 48. Cross-section based on seismic section, illustrating the formation of so-called pseudo-escarpments (PSE) at the landward end of dipping basalts. Sediments: pale blue to light brown layers; basalts: green. Landward direction to the left. Slightly modified from H.C. Larsen (1990). uation of continental crust begins, lies $25-40 \mathrm{~km}$ landwards of the continent-ocean boundary (H.C. Larsen \& Saunders 1998 fig. 12; H.C. Larsen et al. 1998 fig. 7). Thus the continent-ocean transition zone may be a little wider than shown on the 1:2 500000 map, and the continent-ocean boundary probably lies about $25 \mathrm{~km}$ north-west (landwards) of the position shown on the map.

At c. $68^{\circ} \mathrm{N}$ the eastern margin of continental Greenland cuts obliquely across linear magnetic anomalies 24-13 in the oceanic crust. This was not originally regarded as the expression of a transform fault, but rather as an oblique ocean-continent transition along a former northward-propagating spreading ridge (H.C. Larsen 1988). However, prior to anomaly 13 time, the Jan Mayen microcontinent was attached to East Greenland between c. $68^{\circ}$ and $72^{\circ} \mathrm{N}$. A coast-parallel dyke swarm along Blosseville Kyst between $68^{\circ} 20^{\prime}$ and $70^{\circ} \mathrm{N}$ and voluminous intraplate volcanism in this region may reflect an unsuccessful attempt at continued Eocene spreading along an axis at about the position of the present coast (H.C. Larsen 1988). However, to find the 'missing' magnetic anomalies 24-13 (i.e. Eocene) oceanic crust, it is to the east of the Jan Mayen micrcontinent that one should look (e.g. Lundin \& Doré 2002). During this period a transform fault must have linked the Reykjanes Ridge to the southern end of the Aegir Ridge - the Denmark Strait Fracture Zone (Lundin \& Doré 2002). After anomaly 13 time spreading between Greenland and the Jan Mayen microcontinent propagated northwards, reaching the Jan Mayen Fracture Zone at about anomaly 6 time.

North of Jan Mayen Fracture Zone the 1:2 500000 map shows the COB off East Greenland transgressing magnetic anomalies $24 \mathrm{~B}, 24 \mathrm{~A}$ and 23 at a low angle, indicating that here the spreading ridge propagated towards the south-west. Newer interpretations of the position of the COB here differ, not only from what is shown on the map but also from one another. Tsikalas et al. (2002) extend anomalies 24B and 24A into the shelf, the anomalies crossing the shelf edge at approximately $74^{\circ} 15^{\prime} \mathrm{N}$ and $73^{\circ} 55^{\prime} \mathrm{N}$ respectively. This implies that the shelf has prograded over oceanic crust here, and that there was no south-westwards progradation of the spreading axis in this region. However, refraction seismic data from the shelf between $72^{\circ}$ and $74^{\circ} \mathrm{N}$ (Voss \& Jokat 2007) show clearly that the boundary of true oceanic crust lies very slightly seawards of what is shown in the 1:2 500000 map, while the transition zone, described by Voss \& Jokat as "intruded and stretched continental crust", extends landwards $100 \mathrm{~km}$ from the COB. Farther 


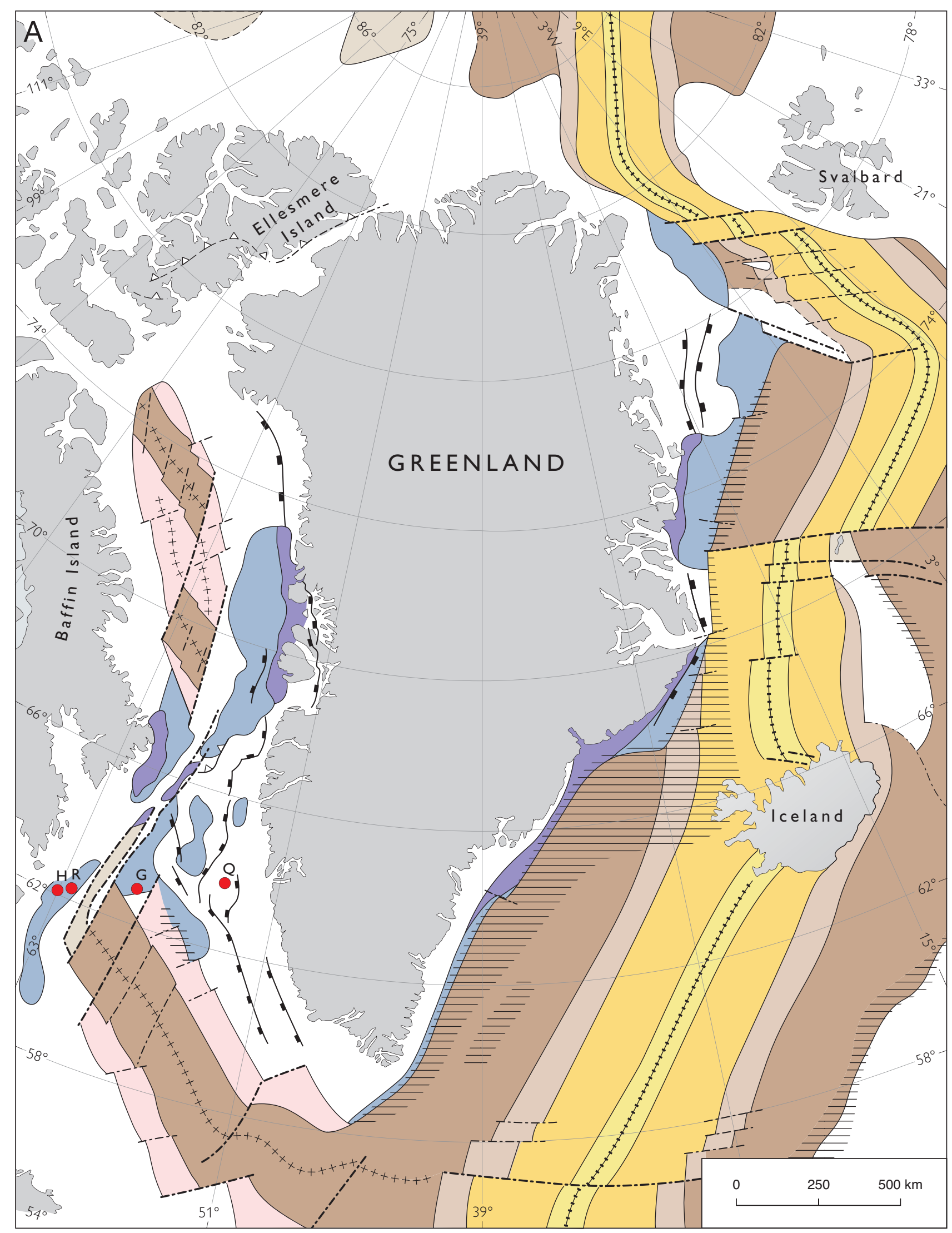


Land areas. Maritime areas underlain by continental or transitional crust Oceanic crust, Pliocene-Recent Oceanic crust, Miocene Oceanic crust, Oligocene Oceanic crust, Eocene Oceanic crust, Paleocene Oceanic crust, Age uncertain Palaeogene basalts exposed at seabed in areas underlain by continental or transitional crust Palaeogene basalts buried under younger sediments in areas underlain by continental or transitional crust

\section{Seaward-dipping reflectors}

$\ldots$ Oceanic spreading axis, active

+++ Oceanic spreading axis, extinct

--- Transform fault

Major basin-bounding fault; mark on downthrown side

$\_$Compressional fault, thrust Exploration well; Q: Qulleq-1,

- G: Gjoa G-37, R: Ralegh N-18, $\mathrm{H}$ : Hekja 0-71

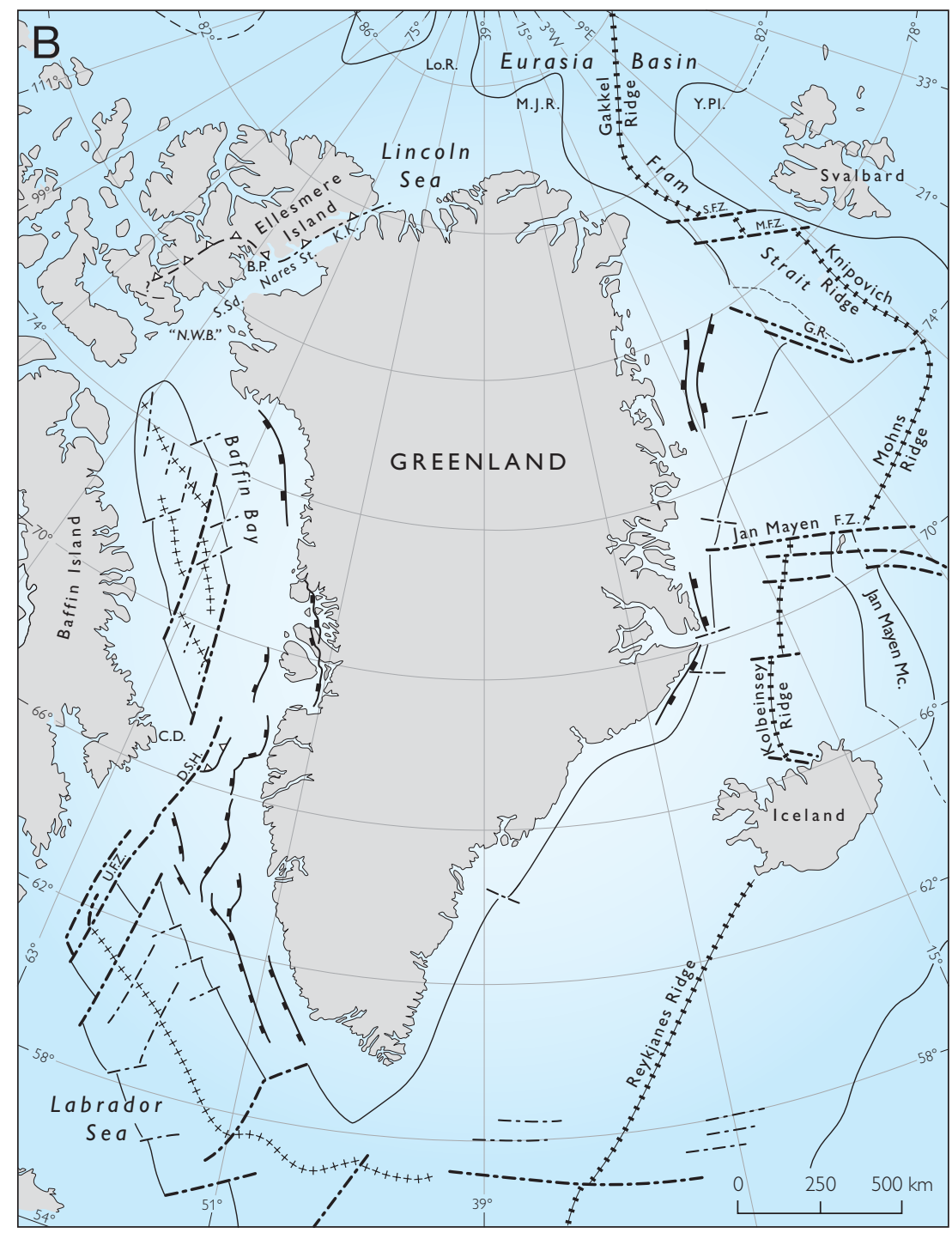

Fig. 49. A (facing page): Map showing distribution of crustal types and major structures offshore Greenland. Only basalts overlying continental crust are shown. B (above): Place names and names of structural features shown in A or mentioned in the text. Lo.R.: Lomonosov Ridge; M.J.R.: Morris Jesup Rise; Y.Pl.: Yermak Plateau; S.F.Z.: Spitsbergen Fracture Zone; M.F.Z.: Molloy Fracture Zone; G.R.: Greenland Ridge; Jan Mayen F.Z.: Jan Mayen Fracture Zone; Jan Mayen Mc.: Jan Mayen Microcontinent; U.F.Z.: Ungava Fracture Zone; D.S.H.: Davis Strait High; 'N.W.B.': 'North Water Bay’; S.Sd.: Smith Sound; K.K.: Kennedy Kanal; B.P. Bache Peninsula; C.D.: Cape Dyer.

north Berger \& Jokat (2008), on the basis of reflection seismic data, place the landward boundary of oceanic crust a little seawards of the position shown on the enclosed 1:2 500000 map, the difference between Berger \& Jokat's interpretation and the 1:2 500000 map diminishing south-westwards.

\section{North-East Greenland (77-83 $\mathrm{N})$}

At the Greenland Ridge (see Fig. 49A, B) a sliver of continental crust extends from the shelf south-eastwards along the fracture zone until this turns slightly anticlockwise. North-east of the fracture zone there is an area tentatively interpreted as extremely thinned continental crust (Døssing et al. 2008); this is included in the area shown as continental or transitional crust in Fig. 49A. North of the fracture zone the position of the $\mathrm{COB}$ steps to the north-west. Sea-floor spreading magnetic anomalies have lower amplitudes and are more ambiguous in the oceanic area north of the fracture zone and in the Fram Strait than in the oceanic region to the south. At the time the 1:2 500000 map was compiled, there was no agreed interpretation of magnetic anomalies, and hence 
the age of oceanic crust between the Hovgård Ridge (position $c .0^{\circ} \mathrm{W}, 78^{\circ} 30^{\prime} \mathrm{N}$, shown as transitional crust) and the Spitsbergen Fracture Zone (see Fig. 49A, B) is shown as [g] (age unspecified) on the map. Recently, however, Engen et al. (2008) have reviewed the geology and evolution of the Fram Strait and provisionally identified and numbered several sea-floor spreading magnetic anomalies in the seaway, so that the oceanic crust in the strait can now be subdivided chronostratigraphically as it is elsewhere (Fig. 49A).

Between the Greenland Ridge and the Molloy Fracture Zone (Fig. 49A, B) the oldest sea-floor spreading magnetic anomaly that can be identified with confidence is anomaly 18 (39 Ma; Middle Eocene) (Engen et al. 2008). Regarding the COB here, Døssing et al. (2008) place the seaward limit of continental crust slightly east of where it is shown on the 1:2 500000 map, close to the shelf edge.

The north-east margin of continental Greenland, north of $79^{\circ} \mathrm{N}$, has a very different character. It is shown on the enclosed map as a former intracontinental transform plate boundary. A consensus exists that a substantial dextral displacement of Svalbard relative to North-East Greenland took place along an intracontinental NW-SE megashear, the De Geer megashear (Harland 1969; Engen et al. 2008), in the time interval corresponding to magnetochrons 24R-13 (earliest Eocene - earliest Oligocene). In the early Oligocene, rifting began to take place along this zone, and a spreading ridge, the Knipovich Ridge, linking the Mohns Ridge and the Gakkel Ridge, developed along the site of the earlier transform fracture. Since this time, the flanking continental margins have developed as passive margins separated by an obliquely spreading ocean (e.g. Vogt \& Tucholke 1989; Eldholm et al. 1990; Kristoffersen 1990; Engen et al. 2008; Faleide et al. 2008). Spreading propagated south-eastwards from the Gakkel Ridge so that the earliest identified magnetic anomaly between the Yermak Plateau and the Morris Jesup Rise is anomaly 7, while in the Fram Strait the oldest anomaly approaching the Spitsbergen Fracture Zone is anomaly 5 (Engen et al. 2008). It has also been suggested that mantle peridotite has been exposed in this part of the strait (Jokat et al. 2005). Whatever the case, the 1:2 500000 map is incorrect with regard to the age of the oceanic crust in this area.

\section{The Morris Jesup Rise and the Yermak Plateau}

One particular outstanding problem here is the nature of the crust underlying the Morris Jesup Rise and its conjugate feature, the Yermak Plateau, north of Svalbard (Fig. 49A, B). Recent work has shown that the Yermak Plateau south of $82^{\circ} \mathrm{N}$ (the area shown without colour on the 1:2 500000 map) is most likely underlain by continental crust, and that the south-west margin of this part of the plateau is a continental margin (Ritzmann $\&$ Jokat 2003; Engen et al. 2008).

North of $82^{\circ} \mathrm{N}$ the Yermak Plateau runs NE-SW; it is this outer part of the plateau that adjoined the Morris Jesup Rise prior to the opening of the Eurasia Basin and Fram Strait. The nature of the crust in the outer Yermak Plateau is still open to discussion. Jokat et al. (2008) favour a model of stretched and intruded continental crust, and Engen et al. (2008) argue against the earlier hypothesis that this part of the plateau formed by voluminous oceanic volcanism at an Eocene triple junction between Eurasia, Greenland and North America, pointing out that the termination of sea-floor spreading magnetic anomalies 23-13 at the north-east flank of the outer plateau favours a continental outer Yermak Plateau.

A limited amount of work has been done on the conjugate feature, the Morris Jesup Rise. Available data indicate that the feature is underlain by thinned and rifted continental crust (Ostenso \& Wold 1977). As is also the case in the Yermak Plateau, high-amplitude and irregular magnetic anomalies suggest the presence of volcanic rocks, possibly of Cretaceous age (Engen et al. 2008). Dawes (1990) favoured the view that the Morris Jesup Rise has a complex structure and that it may contain appreciable continental remnants below a thick cover of volcanic rocks.

\section{The continental margin off West Greenland Southern West Greenland $\left(58-64^{\circ} \mathrm{N}\right)$}

The continental margin off southern West Greenland also presents problems of interpretation, although more reflection seismic data are available from this area. There has also been some controversy as to when sea-floor spreading in the Labrador Sea began, as discussed in the following, but all agree that sea-floor spreading between Greenland and Canada began earlier than in the North Atlantic, and that it had ceased by magnetochron 13 time.

Distinct linear magnetic anomalies can be seen in the Labrador Sea off South-West Greenland (Srivastava 1978). The earliest magnetic anomalies trend NNW-SSE, while the younger anomalies (24 and younger) trend 
NW-SE, parallel to an extinct spreading axis roughly midway between Canada and Greenland.

The oldest unambiguous magnetic anomaly in the Labrador Sea is anomaly 27. The crust landward of this is shown as transitional crust on the 1:2500 000 map. Srivastava (1978) and Roest \& Srivastava (1989) indicated that linear magnetic anomalies could be identified much closer to the continental shelf than anomaly 27 , suggesting 31 or 33 as the number of the oldest anomaly. However, a substantial body of evidence has accumulated since 1991 that refutes the hypothesis that pre-anomaly $27 \mathrm{R}$ oceanic crust exists in the Labrador Sea. Modelling of the magnetic data acquired by the Bundesanstalt für Geowissenschaften und Rohstoffe (BGR), during seismic transects across the Labrador Sea in 1977, indicates oceanic crust with alternating strips of normally and reversed magnetised crust landwards as far as anomaly 26R or 27R (Chalmers 1991; Chalmers $\&$ Laursen 1995). Landwards of this, a model assuming thinned and rifted continental crust intruded by reversed magnetised igneous material provides the best fit with the observed data. South of $62^{\circ} \mathrm{N}$ it appears that serpentinised peridotite subcrops sediments in the outer part of the transitional zone and that the remnants of continental crust are very thin (Chian \& Louden 1994; Chalmers 1997). Whatever the case, the seawards limit of normal continental crust off southern West Greenland lies well to the south-west of the continental slope, at water depths of more than $1500 \mathrm{~m}$. This interpretation of the distribution of crustal types is supported by the structural pattern seen in the seismic lines. Both the normal continental crust and the zone of transitional crust show large tilted fault blocks overlain by syn- and post-rift sediments (Chalmers \& Pulvertaft 2001). The oldest sediments are most likely of Early Cretaceous age (see later).

Definitive evidence concerning the crustal structure in the inner Labrador Sea was obtained when the Qulleq-1 exploration well was drilled in 2000 at $63^{\circ} 49^{\prime} \mathrm{N}, 54^{\circ} 27^{\prime} \mathrm{W}$. According to Srivastava \& Roest (1999 fig. 5), this should lie on magnetic anomaly 33 (73.6-79 Ma, middle Campanian; Cande \& Kent 1995), but the well terminated in Santonian sandstone without reaching basement (Christiansen et al. 2001), showing that the basement here must be older than oceanic crust anywhere in the North Atlantic region north of $56^{\circ} \mathrm{N}$. The crustal structure in the inner Labrador Sea has recently been studied in a reflection/refraction seismic transect running WSW from the Qulleq-1 well to the Gjoa G-37 and Hekja 0-71 wells off eastern Canada. This new seismic line shows that oceanic crust is restricted to two narrow zones at or close to the Ungava Fracture Zone, a major transform zone that transferred sea-floor spreading through the Davis Stræde (Davis Strait) into Baffin Bugt (Baffin Bay; Fig. 49A, B; Funck et al. 2007). Funck et al. believe that these zones of oceanic crust formed when phases of transtension along the fracture zone created gaps which were filled with melt that formed new oceanic crust.

\section{Davis Stræde $($ c. 64-69 $\mathrm{N})$}

The crust under Davis Stræde is estimated to be $22 \mathrm{~km}$ thick (Keen \& Barrett 1972), which is intermediate between the thickness of normal oceanic and continental crust. There is a basement high within the strait (the Davis Strait High), where the sedimentary cover is thin and locally virtually absent. Palaeogene volcanic rocks have been recovered from the high (Srivastava 1983; Williamson et al. 2003), and it has been suggested that the high is a volcanic plateau formed by hotspot volcanic activity. Hotspot activity is also suggested by the occurrence of thick picritic lavas of Paleocene age in the Disko - Nuussuaq - Svartenhuk Halvø area in central West Greenland and at Cape Dyer (Fig. 49B) on the south-east side of Baffin Island in Canada (Clarke \& Upton 1971; Clarke \& Pedersen 1976). On the Greenland side of the strait, strata of Late Cretaceous age have been traced on seismic lines westwards from the Ikermiut-1 exploration well $\left(66^{\circ} 56^{\prime} \mathrm{N}\right)$ onto the eastern flank of the high (Chalmers et al. 1995), indicating that the high is formed of pre-Late Cretaceous rocks. An E-W seismic profile across the high west of the Ikermiut- 1 well shows dipping internal reflectors within the high (Gregersen \& Bidstrup 2008), suggesting the presence a sedimentary unit. The very high abundance of Ordovician carbonates in dredge samples collected on the high suggests that this unit consists of Ordovician limestones (Dalhoff et al. 2006), a possibility supported by the occurrence of Ordovician carbonates in wells offshore Labrador (Bell \& Howie 1990) and onshore at 'Fossilik' c. $65 \mathrm{~km}$ east of Maniitsoq in West Greenland (Stouge \& Peel 1979; [9] on the 1:2 500000 map). The crust under Davis Stræde is therefore interpreted by the Survey as being formed of thinned continental crust, in accordance with the interpretation of the distribution of crustal types farther south. 


\section{Baffin Bugt $\left(69-77^{\circ} \mathrm{N}\right)$}

The distribution of crustal types underlying Baffin Bugt has not yet been mapped out with certainty, not least because linear sea-floor spreading magnetic anomalies are not distinct in this region. In the central, deep part of Baffin Bugt refraction seismic experiments have shown that the crust is very thin, the $\mathrm{M}$ (moho) discontinuity lying only $11 \mathrm{~km}$ below sea-level. The thickness of the cover of sediments exceeds $4 \mathrm{~km}$ in all but the southernmost part of this region. Seismic velocities in the crust below these sediments are in the range $5.7-7.0 \mathrm{~km} / \mathrm{sec}$ (Srivastava et al. 1981; Balkwill et al. 1990), in agreement with those known from oceanic layers 2 and 3. Gravity and magnetic evidence (see next paragraphs) is also consistent with the interpretation of the central part of Baffin Bugt as being underlain by oceanic crust (e.g. Balkwill et al. 1990). However, geophysical evidence has been presented which indicates that in north-western Baffin Bugt continental crust is replaced oceanwards by a layer of serpentinised mantle, which would account for the lack of distinct linear magnetic anomalies in this area (Reid \& Jackson 1997). The weakness of linear sea-floor spreading magnetic anomalies could also be attributed to very oblique spreading (see Roots \& Srivastava 1984) and to the dampening effect of the thick sedimentary cover.

In spite of the weakness of the magnetic anomalies, Oakey (2005) has succeeded in interpreting linear anomalies between $69^{\circ}$ and $73^{\circ} \mathrm{N}$ and divided these into two directions, NNW-SSE and NW-SE, corresponding respectively to the Paleocene and Eocene anomalies in the Labrador Sea. Oakey's interpretation has been accepted in the recently published 1:5000 000 map of the entire polar region north of $60^{\circ} \mathrm{N}$ (Harrison et al. 2008), on which the oceanic crust in Baffin Bugt is divided into crust of Paleocene and Eocene age. The same interpretation is shown in Fig. 49A. The extinct spreading axis located by Chalmers \& Pulvertaft (2001) is the axis of Eocene spreading. Oakey (2005) agrees with Chalmers $\&$ Pulvertaft (2001) that the major transfer faults along which the spreading axis was displaced, trend $c . \mathrm{N}-\mathrm{S}$.

In the absence of easily recognisable sea-floor spreading magnetic anomalies, the landward limit of proven oceanic crust cannot yet be placed with any degree of confidence. Existing released geophysical data are not sufficient to allow any interpretation of the position, width and nature of the continent-ocean transitional zone. On the 1:2 500000 map the area underlain by continental crust was delineated on the evidence of crustal thickness and structural style (large extensional faults and rotated fault blocks), the latter being known from the KANUMAS reconnaissance seismic survey (Whittaker et al.
1997). In southern Baffin Bugt a recently acquired NW-SE refraction seismic line has revealed a material with high velocity $(6.8 \mathrm{~km} / \mathrm{s})$ underlying sediments at $c$. $68^{\circ} 40^{\prime} \mathrm{N}$, east of the N-S transform fault running N-S at $c .60^{\circ} \mathrm{W}$ (T. Funck, personal communication 2009). This could be oceanic crust, but at present neither the age nor the north-south extent of this high velocity layer is known.

\section{Nares Stræde $\left(77-82^{\circ} \mathrm{N}\right)$}

The nature of the geological structure underlying Nares Stræde, the linear seaway separating Greenland from Ellesmere Island (Fig. 49B), has for some time been a controversial subject (Dawes \& Kerr 1982; Tessensohn et al. 2006). Geophysicists have argued that the strait is the site of a major transform fault with a left-lateral displacement of more than $100 \mathrm{~km}$ that accommodated the opening of the Labrador Sea and Baffin Bugt during the Palaeogene, and also of movement normal to the strait (e.g. Srivastava 1985). In contrast, geologists familiar with the surrounding onshore geology find that there is no significant lateral displacement in Smith Sund (Smith Sound). Several geological markers correlate perfectly from the Thule-Inglefield Land area in Greenland to south-east Ellesmere Island south of the Bache Peninsula (Dawes 2009a). However, in the Kennedy Kanal (kanal = channel) and Robeson Kanal and along the north-west coast of Kennedy Kanal, both thrusting and sinistral strike-slip faulting have been observed (Tessensohn et al. 2006), and a strike-slip displacement of up to $70 \mathrm{~km}$ is considered possible (Harrison 2006). The apparent contradiction between what can be interpreted in Kennedy Kanal and what is observed across Smith Sund can be resolved if south-east Ellesmere Island is geologically speaking part of the Greenland plate. Assuming this is the case, the tectonic junction between Greenland and Ellesmere Island runs along the north-west side of Kennedy Kanal as far south as $80^{\circ} \mathrm{N}$ and then turns inland just north of Bache Peninsula, where the strikeslip displacement in and along the north-west coast of Kennedy Kanal is transferred into thrusting along the southern front of the Eurekan Orogen (Fig. 49A). The cumulative shortening across the major thrust zones of the Eurekan Orogen has been estimated to be of the order of $100 \mathrm{~km}$ (De Paor et al. 1989).

Recent work in Baffin Bugt has diminished the likelihood that Nares Stræde is the site of a major transform fault, because 1) the direction of transform fracture zones and hence spreading movement in this area is almost 
north-south, i.e. at an angle of about $40^{\circ}$ to Nares Stræde (see Fig. 49A, B; Wheeler et al. 1996; Whittaker et al. 1997; Chalmers \& Pulvertaft 2001; Harrison et al. 2008) and 2) the width of the area of oceanic crust in Baffin Bugt may be much less than previously supposed (Oakey 2005; Harrison et al. 2008)). It may well be that Baffin Bugt spreading has been accommodated to a substantial degree by a series of rifts in the Canadian Arctic Islands together with compression in the Eurekan orogen, just as the Gakkel Ridge spreading axis terminates in a system of rifts and extension zones in the Laptev Shelf north of Siberia (Drachev 2000).

\section{The continental margin off North Greenland, west of the Morris Jesup Rise}

Ice conditions in Lincoln Hav (the Lincoln Sea) off North Greenland are the most severe anywhere in Greenland waters. Consequently, the only indications of what might underlie the sea were for many years provided entirely by airborne geophysical data. Summarising the results of earlier work in the region, Dawes (1990) concluded that while gravity data from Lincoln Hav suggest that the North Greenland margin is underlain by thinned continental crust, the crustal structure of the offshore region is conjectural. For this reason a wide area is shown without colour on the 1:2500 000 map.

In 2006 geophysicists succeeded in acquiring two wide-angle refraction/reflection seismic lines on the sea ice north of Ellesmere Island and Greenland (Dahl-Jensen et al. 2006). These seismic sections show that thinned continental crust continues northwards from the inner Greenland shelf under a $2000 \mathrm{~m}$ deep channel to the southern end of the Lomonosov Ridge. Consequently it is now believed that the entire area shown without colour as 'type of crust unknown' on the 1:2 500000 map is underlain by thinned continental crust. The $>2000 \mathrm{~m}$ deep area shown as underlain by oceanic crust older than $45 \mathrm{Ma}$ [f] on the 1:2 500000 map is also likely to be underlain by continental/transitional crust, an inference supported by the fact that linear sea-floor spreading magnetic anomalies identified to the north do not continue into this area (Engen et al. 2008). The study by DahlJensen et al. (2006) also showed that a previously suspected deep sedimentary basin underlying Lincoln Hav does in fact exist (see later).

\section{Offshore sedimentary basins (Fig. 56)}

Reflection seismic surveys have shown that large sedimentary basins occur offshore East Greenland between latitude intervals $67-72^{\circ} \mathrm{N}$ and $75-80^{\circ} \mathrm{N}$. In the intervening area there are extensive Palaeogene basalts below which thick sedimentary successions have been tentatively interpreted, but these cannot be resolved in existing seismic data. Offshore West Greenland there are rift basins with substantial thicknesses of sediment as far north as $76^{\circ} \mathrm{N}$, and also smaller basins in southern Nares Stræde. As just mentioned, under Lincoln Hav a major sedimentary basin has recently been identified (DahlJensen et al. 2006; K. Sørensen, personal communication 2009).

\section{North-East Greenland shelf $\left(72-80^{\circ} \mathrm{N}\right)$}

The existence of thick sedimentary successions on the North-East Greenland shelf was first suggested on the basis of interpretation of aeromagnetic data (Thorning et al. 1982; H.C. Larsen 1984). Seismic and gravity data acquired as part of the KANUMAS project confirmed the existence of major sedimentary basins under this shelf, but at the time the 1:2500 000 map was printed, very few details had been released. Later a summary of the structure and succession in the basins in this shelf has been published (Hamann et al. 2005).

The sediments on the shelf were deposited in two basins separated by a basement high, the Danmarkshavn Ridge (Fig. 50A). Judging from the known geology of the Barents Sea, the Norwegian shelf and onshore NorthEast Greenland, the age of these sediments is likely to be Devonian to Recent, with unconformities in the middle Permian and at the base of the Paleocene. In the inner basin the maximum thickness of the basin fill is $c .13 \mathrm{~km}$, and the succession is thought to span the entire period between Devonian and Neogene. A profound unconformity separates the ?Devonian-Cretaceous section from the overlying Paleocene and younger units (Fig. 50B). The presence of a thick salt layer in the deep part of the basin is clearly shown by gravity lows that coincide with diapiric structures seen in the seismic sections (Hamann et al. 2005). This salt formation passes into time-equivalent carbonates deposited on the platform to the west. By comparison to the Nordkapp Basin, Norwegian Barents Sea, the salt is inferred to be of Late Carboniferous - earliest Permian age (Hamann et al. 2005). A very thick succession also occurs in the outer basin. Here, however, it has not been possible to interpret layers lower 


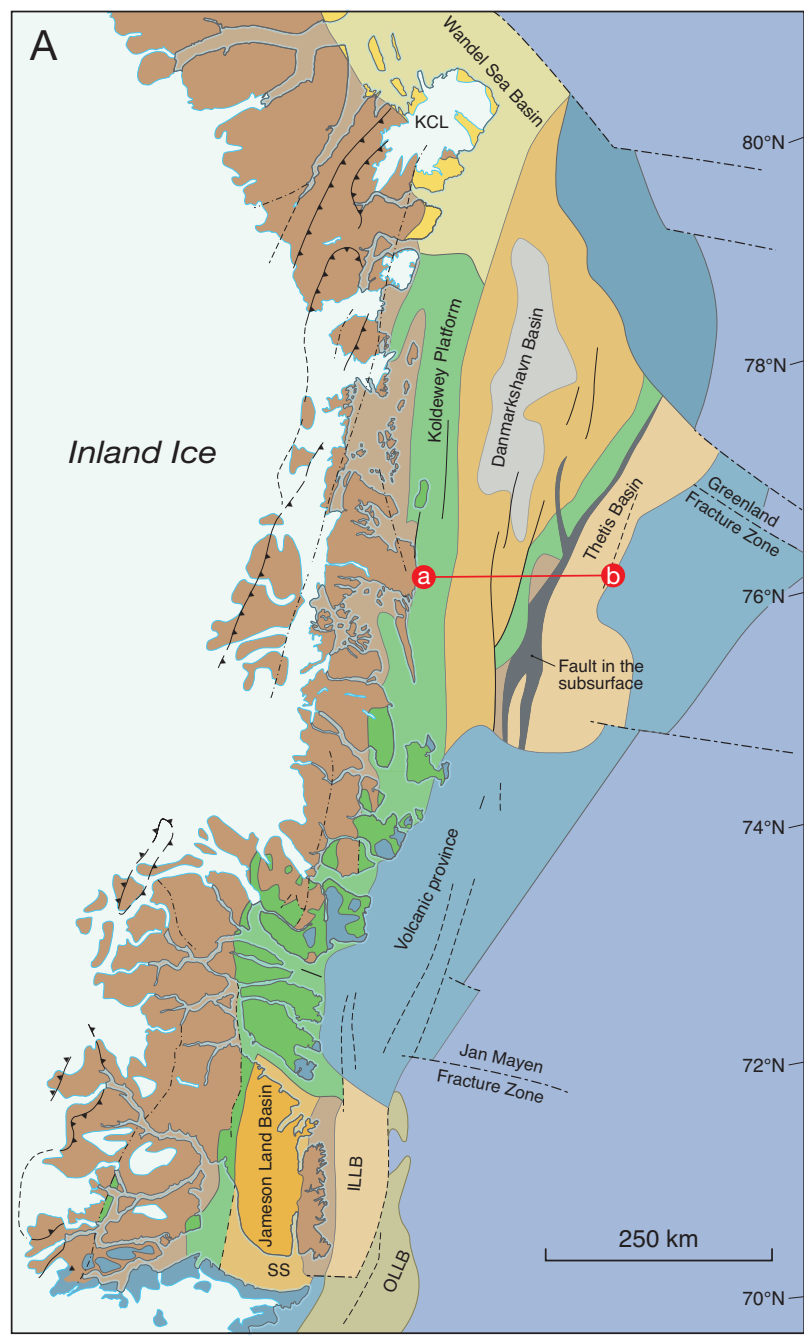

\section{Oceanic crust}

$\square$ Younger sedimentary basins (55-0 million years old)

$\square$ Oceanic basalts

(55-0 million years old)

Continental crust

$\square$ Palaeogene basalts

and intrusions

onshore/offshore

Platform sediment

Palaeozoic-Mesozoic onshore/offshore

Basin: Cretaceous-Cenozoic offshore

Wandel Sea Basin sediments onshore/offshore

Basin: Upper Palaeozic - Mesozoic

onshore/offshore

Basin with salt diapirs

\section{Fold belts and foreland}

Caledonian and older rocks onshore/offshore

... Fracture zone

.... Fault

$\leftarrow$ Thrust fault

ILLB: Inner Liverpool Land Basin

OLLB: Outer Liverpool Land Basin
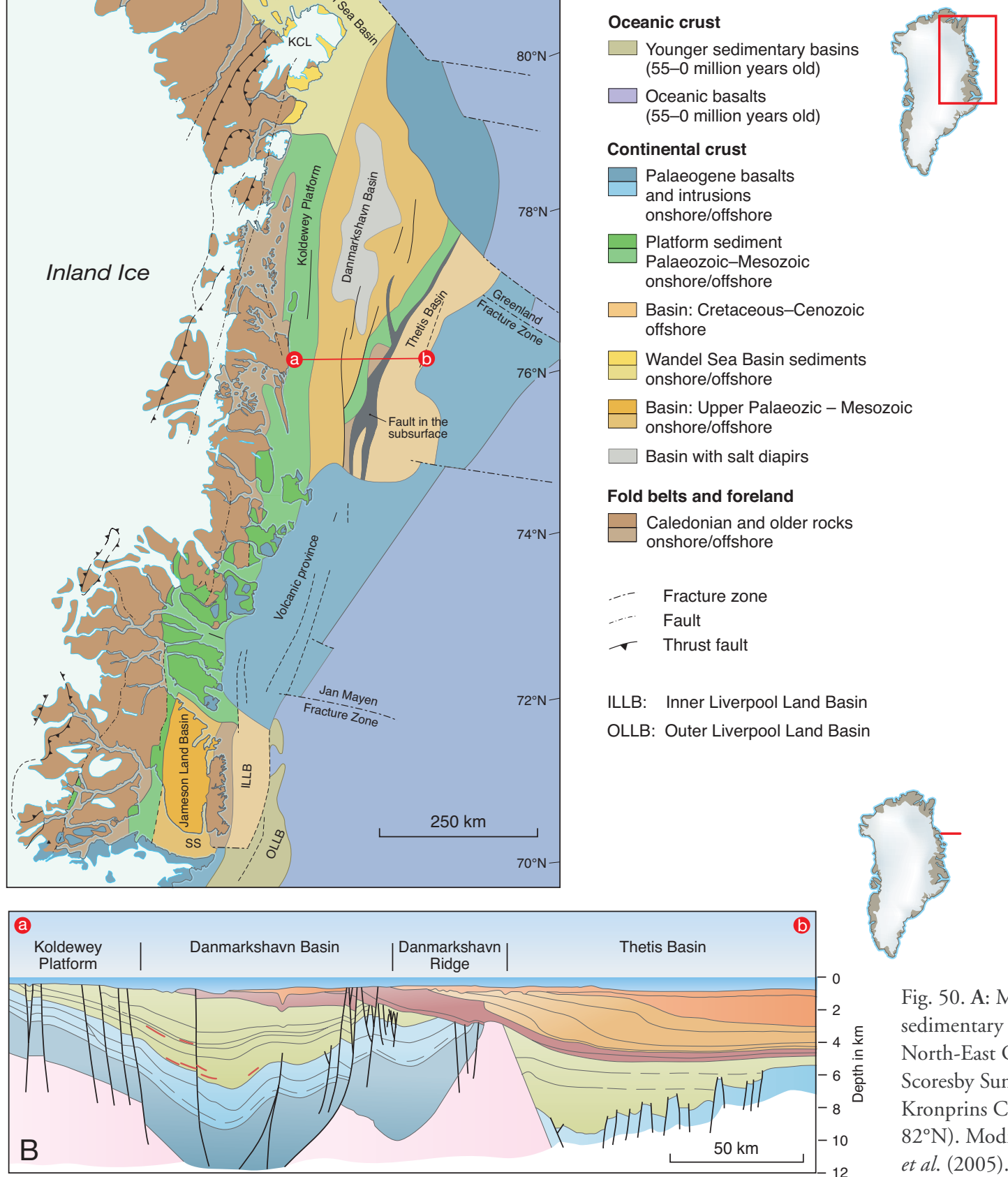

Fig. 50. A: Map showing the sedimentary basins offshore North-East Greenland, between Scoresby Sund $\left(\mathrm{SS}, 70^{\circ} \mathrm{N}\right)$ and Kronprins Christian Land (KCL, $\left.82^{\circ} \mathrm{N}\right)$. Modified from Hamann et al. (2005). B: Cross-section of the North-East Greenland shelf at $c .77^{\circ} \mathrm{N}(\mathrm{a}-\mathrm{b}$ in $\mathrm{A})$. From Hamann et al. (2005).

than ?Jurassic-Cretaceous, although there are indirect indications that older sediments occur here, just as they do in the inner basin.

On the shelf between latitudes $72^{\circ} 15^{\prime}$ and $75^{\circ} 30^{\prime} \mathrm{N}$ extensive volcanic rocks of presumed Palaeogene age have been interpreted from the aeromagnetic and seismic data (H.C. Larsen 1990). In the near-shore area these are exposed at the seabed; eastwards they become increasingly deeply buried under younger sediments. It is considered almost certain that the pre-Paleocene sediments interpreted to the north and south of this area continue beneath the volcanic rocks. High amplitude magnetic anomalies suggest the presence of igneous intrusions in the sedimentary and volcanic rocks just north of $72^{\circ} \mathrm{N}$. 


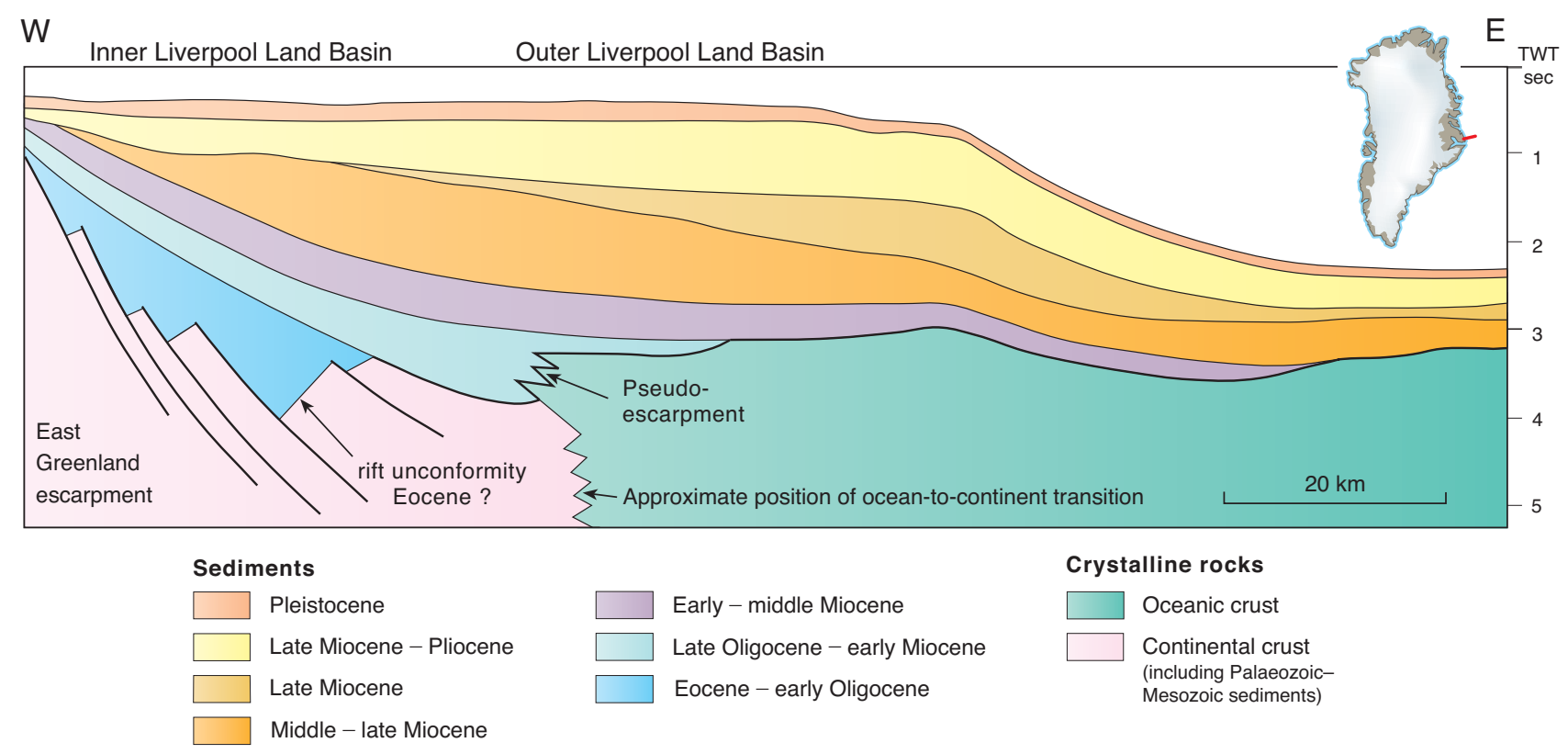

Fig. 51. E-W cross-section across the transition from continental to oceanic crust and the overlying Liverpool Basin at $c .71^{\circ} \mathrm{N}$, East Greenland. From Larsen (1990 plate 6, profile E).

\section{Liverpool Land Basin, central East Greenland $\left(69^{\circ} 30^{\prime}-72^{\circ} \mathrm{N}\right)$}

A very thick succession of sediments can be recognised in the seismic data offshore Liverpool Land. The sediments are particularly thick within the part of the area underlain by continental crust, where the base of the sediments cannot be identified on the existing data. The upper part of the sedimentary succession is a virtually complete Cenozoic succession up to $6 \mathrm{~km}$ thick; this formed a large prograding wedge that spread out across both continental and oceanic crust from the mouth of Scoresby Sund. In the part of the area underlain by continental crust the Cenozoic succession lies with angular unconformity on block-faulted and tilted sediments of pre-Paleocene (Late Palaeozoic - Mesozoic) age (Fig. 51). Where the Cenozoic sediments have prograded into the area underlain by oceanic crust, they are underlain by subaerial lavas seen as seaward-dipping reflectors in the seismic data (Larsen \& Jakobsdóttir 1988; H.C. Larsen 1990).

\section{Blosseville Kyst Basin, East Greenland $\left(67-69^{\circ} 30^{\prime} \mathrm{N}\right)$}

More than $4 \mathrm{~km}$ of post-middle Eocene sediments occupy an elongate, coast-parallel sedimentary basin off the Blosseville Kyst. The sediments lie entirely on Palaeogene basalts. In the area underlain by continental crust there are almost certainly Mesozoic and Paleocene sediments beneath the basalts, as there are onshore and farther to the south (Ocean Drilling Program well 917A; H.C. Larsen et al. 1994a). However, it is not possible to interpret the geology underlying the basalts on the basis of existing seismic data.

\section{Southern West Greenland $\left(60-68^{\circ} \mathrm{N}\right)$}

Several large, more or less coast-parallel, rift basins occur offshore West Greenland between $c .62^{\circ}$ and $68^{\circ} \mathrm{N}$. Smaller basins south of $62^{\circ} \mathrm{N}$ have yet to be mapped properly. The earliest sediments that can be confidently interpreted in these basins are pre- and syn-rift sequences up to $3 \mathrm{~km}$ or more in thickness, the Kitsissut and Appat sequences (Fig. 52); by analogy with the Labrador Shelf, these are believed to be Early Cretaceous (Barremian-Albian) in age (Chalmers et al. 1993; Chalmers \& Pulvertaft 2001). The abundance of Ordovician carbonates in dredge samples collected on the Davis Strait High (Dalhoff et al. 2006) indicates that Ordovician limestones overlie basement locally in the region. As noted above, this possibility is supported by the occurrence of Ordovician carbonates in wells offshore Labrador (Bell \& Howie 1990) and onshore at 'Fossilik' c. $65 \mathrm{~km}$ east of Maniitsoq in West Greenland (Stouge \& Peel 1979; [9] on the 1:2 500000 map). 


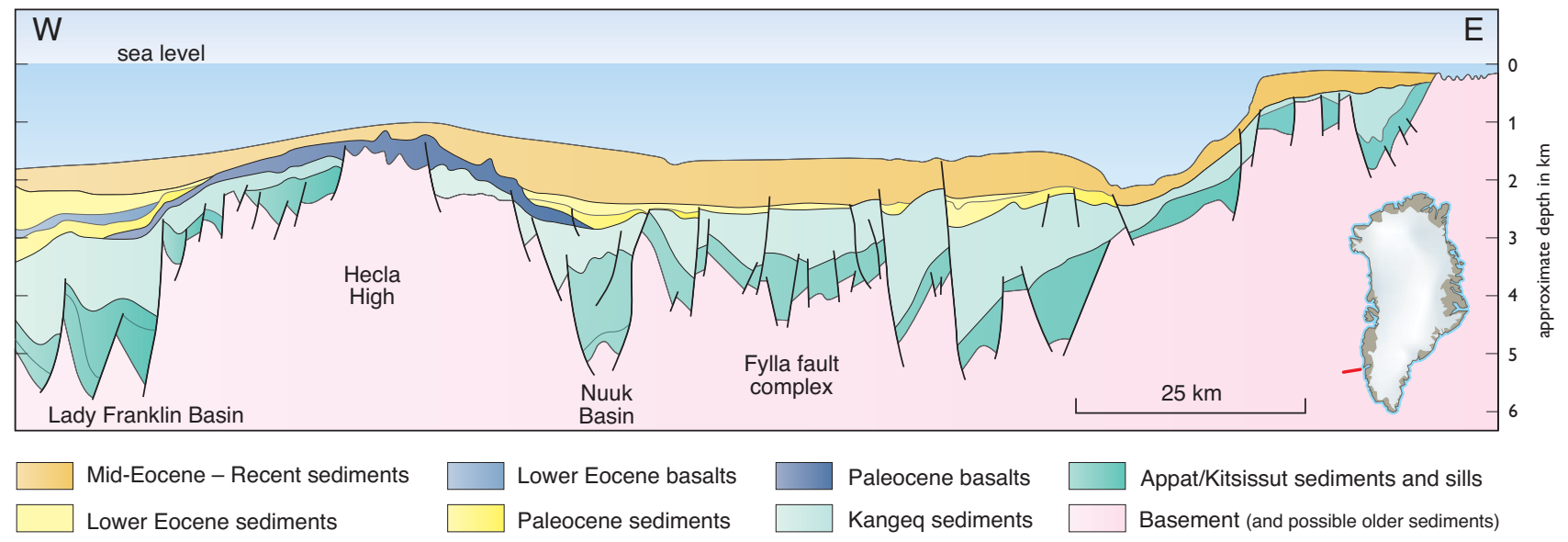

Fig. 52. Zig-zag cross-section through the area west of Nuuk at about $64^{\circ} \mathrm{N}$ based on interpreted and depth-converted seismic data from an unpublished interpretation by J.A. Chalmers.

The Appat sequence is overlain by a widespread Upper Cretaceous mudstone-dominated succession, the Kangeq sequence (Fig. 52), the upper part of which was penetrated in the Ikermiut- 1 well $\left(66^{\circ} 56^{\prime} \mathrm{N}, 56^{\circ} 35^{\prime} \mathrm{W}\right)$ and in the Qulleq-1 well $\left(63^{\circ} 49^{\prime} \mathrm{N}, 57^{\circ} 27^{\prime} \mathrm{W}\right)$. A major hiatus spanning the interval Campanian - early Paleocene (Nøhr-Hansen 2003) probably reflects the same episode(s) of faulting, uplift and erosion as are recorded in the succession in the Nuussuaq Basin to the north (see pp. 57-60). Following these disturbances, fan sands intercalated with mudstones were deposited. Early Palaeogene volcanism gave rise to local 'shields' - the Maniitsoq and Hecla Highs.

Deposition of mudstones continued into the early Eocene, but from the middle Eocene sedimentation was dominated by coarser clastic sediments deposited mainly in southwards prograding sequences. A major middle Eocene (early Lutetian) hiatus occurs in the three northernmost West Greenland wells (Hellefisk-1, Ikermiut-1 and Kangâmiut-1; Nøhr-Hansen 2003), and another major hiatus spans at least the Oligocene (A.B. Sørensen 2006). During the Eocene, compressional structures developed in the area west of the Ikermiut- 1 well as a consequence of transpression along the transform Ungava Fracture Zone, west of the 1:2 500000 map boundary (Chalmers et al. 1993).

A study of dated minor intrusions onshore West Greenland has shown that intrusion forms and melt compositions changed with time, depending on increasing lithospheric attenuation (L.M. Larsen et al. 2009). Significantly, this study suggests that by Late Jurassic earliest Cretaceous time thinning of the lithosphere had reached a stage when sedimentary basins could begin to form in the nascent Labrador Sea.

\section{Central West Greenland $\left(68-73^{\circ} \mathrm{N}\right)$}

The Palaeogene basalts exposed onshore in the Disko Nuussuaq - Svartenhuk Halvø area continue offshore where they have been mapped from seismic and magnetic data over the entire region between latitudes $68^{\circ}$ and $73^{\circ} \mathrm{N}$ (Gregersen \& Bidstrup 2008). In the eastern part of this region the basalts outcrop at the seabed and have been sampled by dredging, but to the west they become increasingly buried under a cover of Eocene and younger sediments. While the upper surface of the basalts can usually be mapped easily from the seismic data, the base of the basalts is difficult to interpret and it is uncertain just where the basalts finally thin out and disappear to the west. Nevertheless, from newer seismic data acquired by the oil industry it can be seen that a substantial thickness of Mesozoic sediments underlies the basalts (Gregersen \& Bidstrup 2008).

\section{North-West Greenland $\left(73-77^{\circ} \mathrm{N}\right)$}

North of $73^{\circ} \mathrm{N}$ seismic data acquired as part of the KANUMAS project confirmed the existence of a very deep graben or half-graben in the west and south-west part of Melville Bugt (Melville Bay; Fig. 53; Whittaker et al. 1997). This had earlier been outlined from aeromagnetic and gravity data acquired in the late 1960s and 


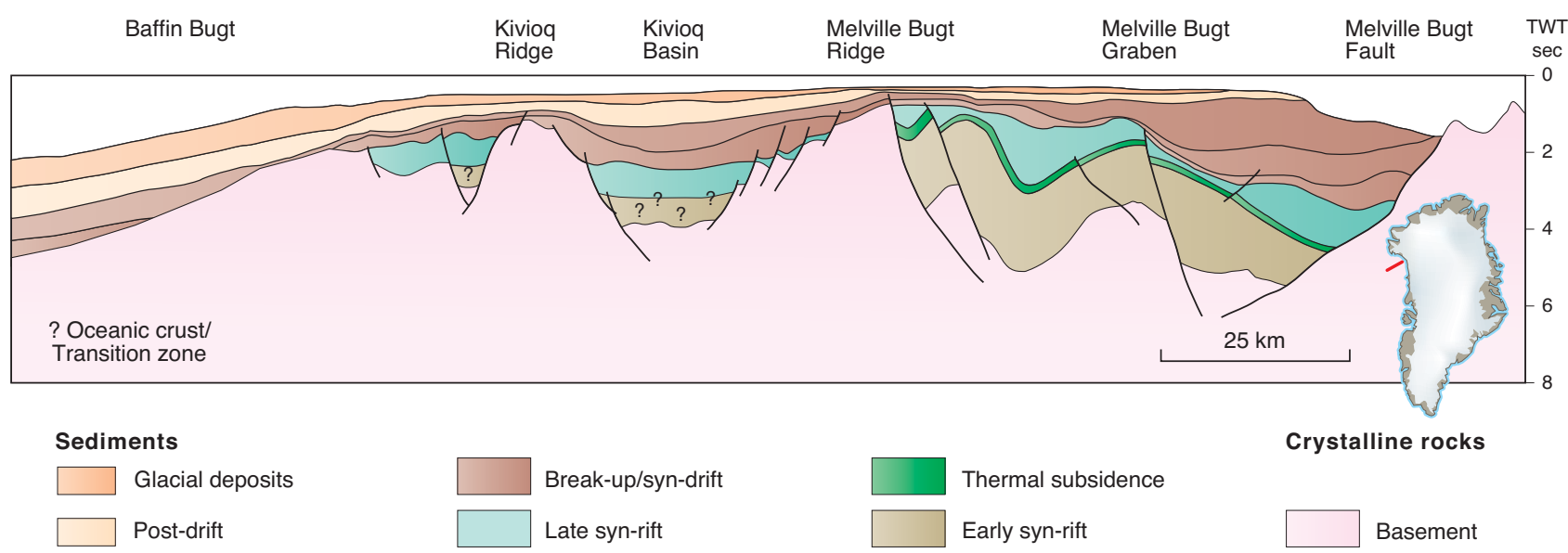

Fig. 53. Representative cross-section offshore North-West Greenland at $c .75^{\circ} \mathrm{N}$ compiled from seismic reflection data. From Whittaker $e$ t al. (1997).

early 1970s. The more recent data have also revealed several other graben and half-graben structures extending to the northern limit of the survey at $76^{\circ} 30^{\prime} \mathrm{N}$. In the Melville Bugt graben the thickness of sediments exceeds $12 \mathrm{~km}$. By analogy with the onshore geology of West Greenland and north-east Canada (Bylot Island), the main phase of rifting is thought to have taken place in the Cretaceous, prior to sea-floor spreading in Baffin Bugt. Later, northern parts of the area were subjected to marked inversion.

Small sedimentary basins with up to $4 \mathrm{~km}$ of ?Cretaceous-Neogene sediments occur in an area known as North Water Bay, between Kitsissut (Carey Islands) and Smith Sund (Neben et al. 2006). The two easternmost of these basins strike NW-SE; these are on line with extensional basins mapped farther south in northern Melville Bugt (Whittaker et al. 1997) and hence are not likely to belong to any pull-apart system (pace Neben $e t$ al. 2006). Sediments belonging to the Thule Supergroup underlie the younger sediments and appear to be continuous right across North Water Bay (Funck et al. 2006).

\section{Offshore North Greenland; the Lincoln Sea Basin}

As already mentioned, ice conditions in Lincoln Hav are the most severe anywhere offshore Greenland, and until recently airborne geophysical data provided the only hints that a major sedimentary basin lies underneath this sea (Sobczak \& Stephens 1974; Kovacs 1982; McMillan 1982). Recently the two wide-angle refraction/reflection seismic traverses successfully carried out by Dahl-Jensen et al. (2006) not only established the continental nature of the crust between the Greenland margin and the southern end of the Lomonosov Ridge but also revealed an up to $14 \mathrm{~km}$ deep sedimentary basin consisting of two layers interpreted to be part of the Arctic Continental Terrace Wedge, under which there is a $9 \mathrm{~km}$ thick layer interpreted to be the offshore continuation of the Upper Palaeozoic - Mesozoic succession in the Sverdrup Basin in the Canadian Arctic Islands. 


\section{Mineral deposits}

Mineral raw materials in Greenland occur in a series of different geological environments that include sedimentary deposits, metamorphic crystalline rocks, and volcanic and plutonic rocks. An overview of selected mineral occurrences with their place names are shown in Fig. 54.

Mining activities have been carried out in Greenland since the middle of the 19th century, with the cryolite mine at Ivittuut as the only long-term mine; it was in operation for a period of 130 years. The cryolite deposit was associated with a granite intrusion in the Mesoproterozoic Gardar Province of South Greenland (p. 38), and represents an example of a very rare type of mineralisation, of which there are only very few similar deposits in the world (Pauly \& Bailey 1999). Other mining activities in Greenland have exploited more common types of mineralisation. The two most important ones were both lead-zinc deposits - one at Mestersvig in East Greenland was associated with quartz veins of probable Palaeogene age, and the other at Maarmorilik in central West Greenland was a stratabound mineralisation in the Palaeoproterozoic Mârmorilik Formation (p. 27). Most recently a gold occurrence in Kirkespirdalen in the Palaeoproterozoic Ketilidian orogen, South Greenland, has been mined (Nalunaq Gold Mine, see below).

Mining activities have so far been very limited in Greenland considering the expected potential of such a large area. However, systematic exploration did not commence until the late 1950s when new legislation governing the mineral sector was introduced to encourage the mining industry to undertake exploration. This was intensified with the introduction of Home Rule status for Greenland in 1979.

In recent years exploration activities have concentrated on prospecting for gold, base metals, platinum elements, molybdenum, iron ore and diamonds. Gold exploration has focused on the Archaean and Palaeoproterozoic Precambrian shield of West Greenland and the Palaeogene Skaergaard layered gabbro intrusion (p. 62) in southern East Greenland (Andersen et al. 1998; Secher et al. 2007). A major new gold province in the Palaeoproterozoic Ketilidian orogen forming the southern tip of Greenland (Steenfelt 2000; Stendal \& Frei 2000; Stendal \& Secher 2002) was first recognised by panning of stream sediments, and in 1992 visible gold was found in quartz veins transecting mafic supracrustal rocks. The Nalunaq Gold Mine in Kirkespirdalen (a valley north-east of Nanortalik) operated from 2004 to 2008, but the mine is presently (2009) placed on 'care and maintenance'. Another find substantiating the interpretation of the Ketilidian orogen as a gold province was made in southernmost South-East Greenland, where gold mineralisation was found in a quartz-bearing shear zone cutting a sequence of mafic to andesitic extrusives and intrusives and associated sedimentary rocks. The promising gold mineralisations in South Greenland are situated at the southern border of the Julianehåb batholith (p. 29), which is also the root zone of a former volcanic arc (Chadwick \& Garde 1996; Garde et al. 1998, 2002; McCaffrey et al. 2004).

Exploration for base metals in recent years has focused on showings in the Lower Palaeozoic Franklinian Basin and Ellesmerian fold belt of North Greenland. A massive sulphide deposit with lead and zinc was discovered in 1993 at Citronen Fjord in Peary Land (Fig. 54; van der Stijl \& Mosher 1998). It occurs as stratiform sheets in a folded sequence of dark argillaceous rocks of the Upper Ordovician to Lower Silurian Amundsen Land Group. The Citronen Fjord deposit is located at the eastern end of the Franklinian Basin, which extends across North Greenland into Arctic Canada and is known to be a significant prospective zone which includes the Polaris zinc-lead mine in Canada.

Diamond exploration has focused on the Archaean and Palaeoproterozoic crystalline shield areas of West Greenland. The kimberlite province in this region includes the Archaean craton and areas of Archaean rocks farther north reworked during the Palaeoproterozoic. The province contains various Meso-Neoproterozoic ultramafic lamprophyres (UML) as well as Mesozoic UML-intrusions.

\footnotetext{
Facing page

Fig. 54. Map of known mineral occurrences in Greenland. The presentation combines the geological map with the knowledge of mineral prospects and deposits gathered over more than 150 years. The main geological divisions on the geological map cover periods from Archaean to Palaeogene and are summarised in the legend. From GEUS Department of Economic Geology.
} 


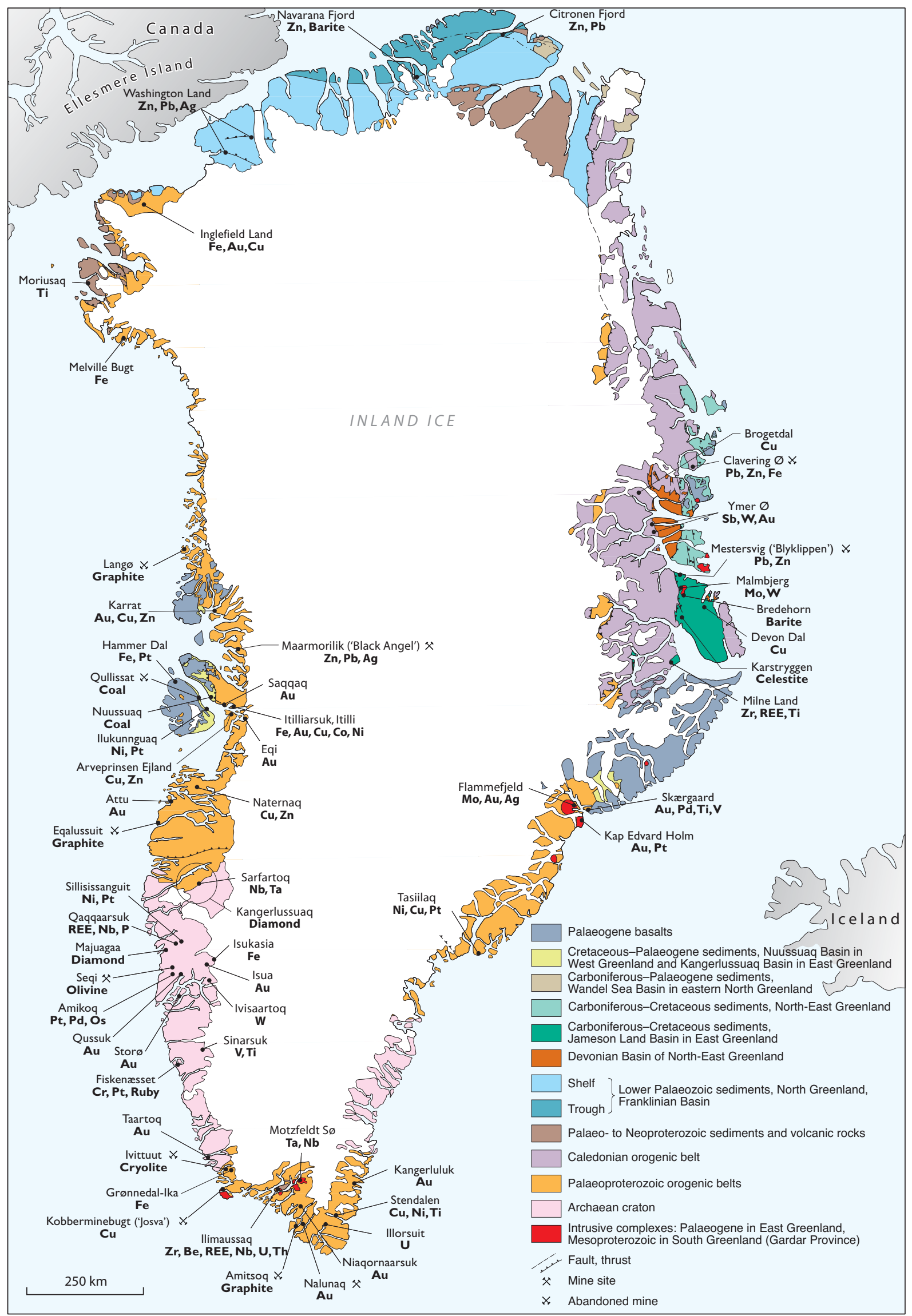


A large number of these intrusions contain diamonds, and intensive exploration activity has been in progress since the 1990s (Secher \& Jensen 2004; Jensen et al. 2004; Nielsen et al. 2009). At present more than 1000 occurrences of diamondiferous kimberlite dykes have been found, and the largest diamond so far discovered is of 2.5 carat. The Archaean block also contains three large intrusive carbonatite complexes with a resource potential for various speciality commodities such as niobium and tantalum.

\section{Mineral occurrences in specific geological settings}

Significant occurrences of a broad range of metallic and industrial minerals are present in all the principal geological provinces in Greenland, ranging in age from Archaean to Quaternary (Fig. 54; Schønwandt \& Dawes 1993; Stensgaard \& Thorning 2009). In broad terms these can be related to five main settings:

Archaean-Palaeoproterozoic high-grade regions

Mesoproterozoic intracratonic intrusions

Palaeozoic orogenic belts

Upper Palaeozoic - Mesozoic basins

Late Phanerozoic intrusions.

The following description covers the principal active and former mines and some significant prospects (Fig. 54); at present (2009) there are two active mines, although one is 'on hold'. On the printed map sheet the locations of only four abandoned mines are shown (Ivittuut cryolite mine in South-West Greenland, Maarmorilik zinc and lead mine in central West Greenland, Mestersvig lead mine in central East Greenland and Qullissat coal mine in central West Greenland). Promising prospects are a large $\mathrm{Zn}-\mathrm{Pb}$ mineral occurrence in Citronen Fjord in North Greenland, a banded iron occurrence at Isukasia in the Nuuk region, a zirconium and rare-earth element prospect/deposit in the Ilímaussaq complex in South Greenland and the Malmbjerg molybdenum deposit in central East Greenland. Information about a large number of mineralised localities is available in the continually updated Greenland Mineralisation Data Bank at the Survey (see: www. geus.dk/gmom: Greenland Mineral Occurrence Map on-line).

\section{Archaean-Palaeoproterozoic high-grade regions}

At Isukasia (Isua supracrustal sequence [69]; Fig. 54) north-east of Nuuk, a major Archaean banded iron formation is composed of interlayered magnetite and chert (Fig. 5). The deposit, which is partly covered by the Inland Ice, has been drill tested and a minimum tonnage of 1900 million tonnes grading $32.9 \% \mathrm{Fe}$ is estimated (Nielsen 1976; Appel 1991).

The Nuuk region in southern West Greenland has revealed a good potential for gold mineralisations (Stensgaard \& Stendal 2007). The gold occurs in the supracrustal parts of the Archaean craton, which largely consists of amalgamated islands arcs, which gradually merged into micro-continental blocks (Windley \& Garde 2009). The supracrustal belts reflect both island-arc and ocean-floor environments, and also contain ultramafic to mafic magmatic intrusions. Gold showings occur in a NNE-trending belt along the fjord Nuup Kangerlua (Godthåbsfjord) from Nuuk to Isukasia, and a multidisciplinary approach has now resulted in division of the occurrences into three main groups (Stensgaard \& Stendal 2007). The occurrences contain up to 3-7 g/t Au with local grades of up to $20 \mathrm{~g} / \mathrm{t}$ Au. Intensive exploration with drilling both north and south of the fjord has been undertaken since 2003.

A series of gold occurrences has also been found in the crystalline basement rocks of the Nagssugtoqidian orogen north-east of Disko Bugt, central West Greenland. Here Archaean orthogneisses with their Archaean and Palaeoproterozoic cover rocks have been variably affected by the $c .2 .0$ to $1.75 \mathrm{Ga}$ Nagssugtoqidian orogeny. The gold is hosted in Archaean metasedimentary and metavolcanic rocks and may be either stratabound or located in veins, breccias or shear zones (Steenfelt et al. 2004). The gold values are modest with only a few ppm in the mineralised zones, but there is a potential for further occurrences in the investigated region.

A folded and metamorphosed Archaean anorthosite complex [85] at Qeqertarsuatsiaat/Fiskenæsset, southern West Greenland (the Fiskenæsset complex; Fig. 54) hosts widespread chromite-bearing layers (Ghisler 1976). The complex, which has a strike length of more than $200 \mathrm{~km}$ and an average thickness of $400 \mathrm{~m}$, has an estimated potential of 100 million tonnes of low-grade chromium ore. Enhanced precious metal values have been reported from the ultramafic parts of the complex (Appel 1992). Ruby-bearing rocks occur at several localities in the Fiskenæsset complex, where the corundum/ruby occurs in zones close to the contact between anorthosite and 


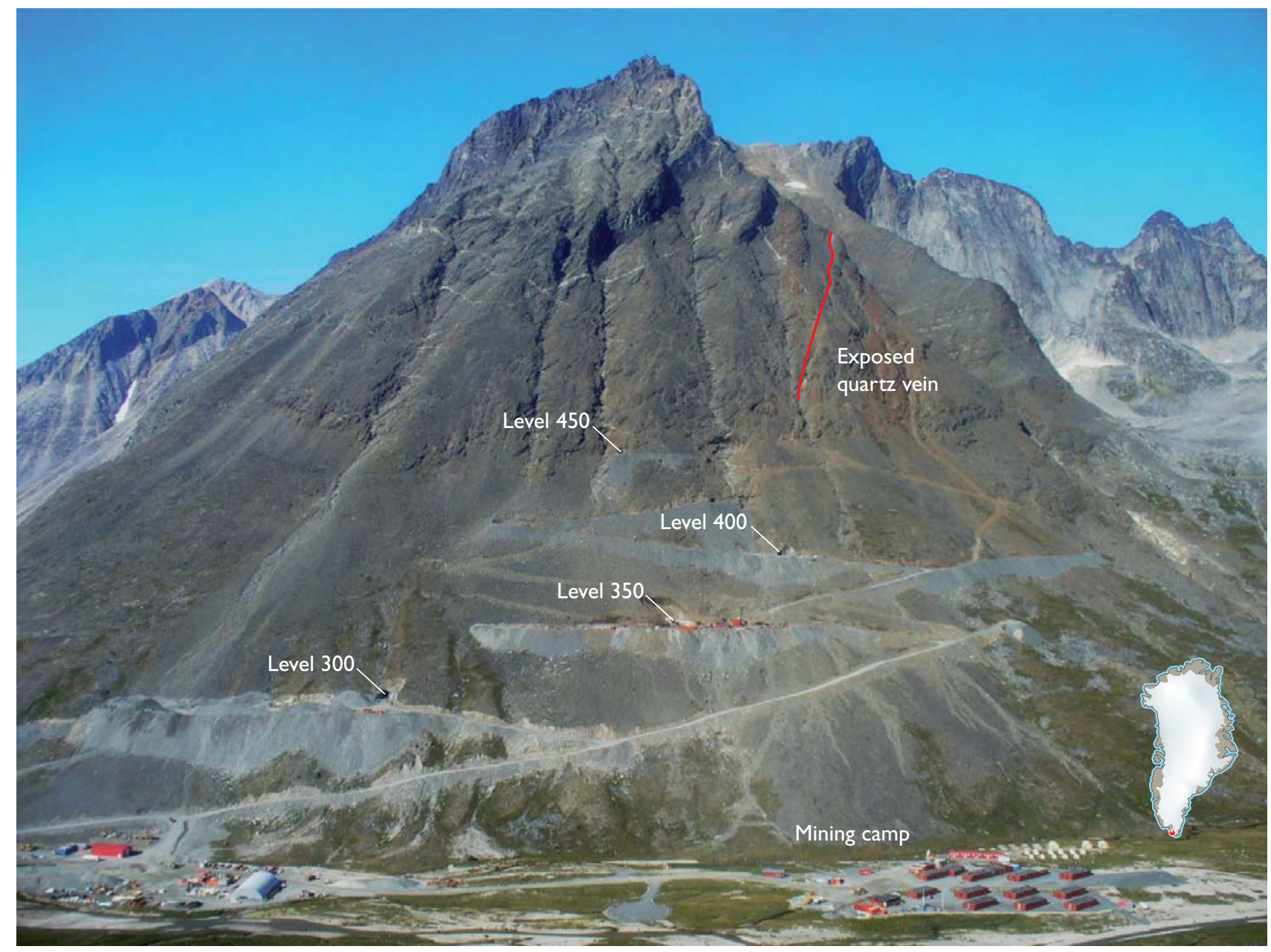

Fig. 55. View of the mining area around the Nalunaq Gold Mine in South Greenland. Access to the underground mine is at four levels of 300, 350, 400 and $450 \mathrm{~m}$. The mine was opened in 2004. Photo: Bureau of Minerals and Petroleum, Nuuk.

amphibolite/ ultrabasite. A mining company has obtained an exclusive exploration licence for rubies, and tests have shown that some types of ruby and sapphire are of gem quality (Secher \& Appel 2007).

A Neoarchaean iron province occurs in the coastal areas along Melville Bugt in North-West Greenland. Geographically it is the largest iron province in Greenland (Dawes 2006) and is traceable in a WNW-ESE-trending belt for $c .350 \mathrm{~km}$. The belt contains magnetite and hematite in quartz-banded iron formation (BIF), massive lenses and layers with iron oxides and disseminated iron minerals in schists. BIF occurs in units of varying thickness, ranging from less than a metre to $40 \mathrm{~m}$ where iron concentrations typically are 30-35\%.

At Maarmorilik, central West Greenland, the Black Angel (Fig. 54) zinc-lead ore bodies hosted in Palaeoproterozoic marble (p. 27; lower part of [62]) were mined in the period 1973-1990. Production totalled c. 11 mil- lion tonnes ore grading $4.0 \% \mathrm{~Pb}, 12.6 \% \mathrm{Zn}$ and $29 \mathrm{ppm}$ $\mathrm{Ag}$. The deposits were almost exhausted in that period, but a re-establishment of the mine is planned for 2010-2011, based on the remaining ore in pillars in the mine combined with other marble-hosted lead-zinc prospects in the area (Thomassen 1991, 2006; MINEX 2008b). Prior to the $\mathrm{Pb}-\mathrm{Zn}$ mining, some 8000 tonnes of marble were quarried at Maarmorilik in 1936-1971.

The Nalunaq Gold Mine in Kirkespirdalen, north-east of Nanortalik, South Greenland (Figs 54, 55) is a small, high-grade gold deposit associated with up to $1.8 \mathrm{~m}$ wide quartz-veins in a major shear zone. The deposit is an orogenic-type gold mineralisation (mesothermal lode gold) hosted in Palaeoproterozoic amphibolite facies volcanic rocks within the Ketilidian orogen. The mine was opened in 2004, but mining was placed on 'care and maintenance' by the owner at the end of 2008. In 2009 a new company is negotiating to take over the 
mine and start production again. Production in 2006 totalled 108000 tonnes of ore with an average gold grade of 17.9 grams per tonne (Secher et al. 2008).

Several large, homogeneous, olivine-rich (dunitic) bodies occur in the Archaean gneiss terrain some $90 \mathrm{~km}$ north of Nuuk. An opencast mine, the Seqi Olivine Mine, was opened in 2005 in the northernmost part of the Niaqunngunaq/Fiskefjord fjord system (see Fig. 54). This homogeneous deposit contains at least 100 million tonnes of high-quality olivine.

\section{Mesoproterozoic intracratonic intrusions}

Cryolite hosted in a Gardar granite stock (part of [56]) at Ivittuut, South-West Greenland (Fig. 54) was worked from 1858 until 1987, and a total of 3.7 million tonnes ore grading $58 \%$ cryolite was quarried from an open pit. In addition to cryolite, galena, chalcopyrite and siderite were extracted as by-products. The main ore body is now exhausted, but there are indications of deep-seated reserves in the area (Bondam 1991).

In the Gardar Ilímaussaq alkaline intrusion (part of [56]; see Fig. 19; Fig. 54) east of Narsaq in South Greenland, a deposit with rare metals such as niobium, tantalum, zirconium, yttrium, rare-earth elements, lithium and beryllium and accessory uranium and thorium has been delimited by diamond drilling, indicating a reserve of 56 million tonnes of $U$ with a grade of $365 \mathrm{ppm}$ (Nyegaard 1979). The rare-earth and other special elements are concentrated in the final, highly volatile, products of the magmatic differentiation. The last rocks to solidify are therefore relatively rich in elements such as niobium, tantalum, zirconium and rare-earth elements (Bondam 1995). The Motzfeldt centre east of Narsarsuaq is another of the large intrusive syenite complexes in the Gardar Province. This centre has preserved accumulations of the mineral pyrochlore which has a high content of tantalum and niobium. The deposit has been explored and is rated as a 'low-grade - large tonnage' type of resource, with 600 million tonnes of ore with $120 \mathrm{~g} / \mathrm{t}$ tantalum and 130 million tonnes of ore with $1400 \mathrm{~g} / \mathrm{t}$ niobium. The deposit is believed to be one of the largest tantalum deposits in the world (H. Sørensen et al. 2006b).

Late Neoproterozoic (604-555 Ma old) in situ kimberlite intrusions and ultramafic lamprophyre dykes are widespread as dykes and sheets in the region around the fjord Kangerlussuaq / Søndre Strømfjord, West Greenland (Secher et al. 2009). They are found on both sides of the boundary between the Archaean craton to the south and the Palaeoproterozoic Nagssugtoqidian orogen to the north. The intrusions have been known since the mid1960s and the first microdiamonds were found in stream sediments in the Sarfartoq river. The finds of microdiamonds led to intensive prospecting, and at present several microdiamond sites have been reported from outcropping kimberlitic rocks (MINEX 2002, 2007a, 2008a, b; Secher \& Jensen 2004). Diamonds and diamond indicator minerals have since been found in numerous samples of stream sediments, in boulders and in situ kimberlites, both in the Sarfartoq area and in the Maniitsoq/Sukkertoppen area $\left(65^{\circ} \mathrm{N}\right)$. In the Sarfartoq area exploration has resulted in finds of commercialsized diamonds of up to 2.5 carats, and in 2008 the exploration company reported the recovery of another large diamond of $c .4$ carat from a dyke. In the Maniitsoq area recent field work has resulted in recognition of a large kimberlite dyke system with a combined length of more than $10 \mathrm{~km}$.

The known carbonatite intrusions of Sarfartoq, Qaqarssuk and Tikiusaaq (legend numbers [59] and [61] on the 1: 2500000 map) within the alkaline province south of Kangerlussuaq / Søndre Strømfjord have a recognised potential for accumulations of niobium and rareearth elements (Secher \& Jensen 2004; Kolb \& Stensgaard 2009). Tikiusaaq was found in 2005 (Steenfelt et al. 2006) and is thus not indicated on the map.

\section{Palaeozoic orogenic belts}

South of Citronen Fjord (Fig. 54) in Peary Land, North Greenland, a large sulphide-rich zone hosts a major leadzinc-bearing, Sedex-type, massive sulphide deposit in Ordovician black shales (part of [24]) (Kragh et al. 1997). Diamond drilling since the discovery in 1993 and up to 2008 has yielded $44 \mathrm{~km}$ of core and has indicated a resource of more than 102 million tonnes grading $4.7 \%$ $\mathrm{Zn}+\mathrm{Pb}$ at a $2 \% \mathrm{Zn}$ cut-off grade (van der Stijl $\&$ Mosher 1998; MINEX 2007b, 2008b). The deposit is located north of a prominent palaeo-escarpment separating carbonate shelf sedimentary rocks to the south from deepwater trough sedimentary rocks to the north. The prospect is currently (2009) under evaluation for opening of a mine in the near future.

Another discovery of zinc-lead-silver mineralisation in the same province has been made in Washington Land, western North Greenland, where a galena occurrence is hosted in evaporitic Lower Ordovician carbonates in the platform succession (Jensen 1998). 


\section{Upper Palaeozoic - Mesozoic basins}

At Qullissat (Fig. 54) on Disko, central West Greenland, Cretaceous sub-bituminous coal was mined during the period 1924-1972. A total of about 570000 tonnes of coal was shipped before the mine was closed due to the low coal quality (Schiener 1976). On nearby Nuussuaq, more than 180 million tonnes of sub-bituminous coal distributed in layers more than $0.8 \mathrm{~m}$ thick have been indicated by surface investigations and limited drilling (Shekhar et al. 1982).

\section{Late Phanerozoic intrusions}

The 54.5 Ma old Skaergaard layered gabbro intrusion (Fig. 54) at Kangerlussuaq, north-east of Ammassalik in southern East Greenland, hosts a major deposit of lowgrade palladium, platinum and gold (Bird et al. 1991). Intensive diamond drilling totalling 42 drill holes with a combined length of more than $21 \mathrm{~km}$, has shown a resource of more than 1520 million tonnes grading 0.21 ppm Au, 0.61 ppm Pd and 0.04 ppm Pt (Thomassen \& Nielsen 2006; Secher et al. 2007). The mineralisation is hosted in a $100 \mathrm{~m}$ thick zone with gold and platinumgroup elements accumulated in five intervals with thicknesses of several metres. In these intervals concentrations of gold and platinum-group elements are much higher than the average figures given above. Titanium, vanadium and iron are important additional commodities in the middle of the mineralised zone, and a test profile across the deposit indicates average contents of $6.6 \% \mathrm{TiO}_{2}$, $0.13 \% \mathrm{~V}_{2} \mathrm{O}_{5}$ and $19 \% \mathrm{Fe}_{2} \mathrm{O}_{3}$. Similar mineralisation is known in other nearby intrusions.

Lead-zinc-bearing quartz veins, probably of Palaeogene age, occur in Lower Permian sediments near Mestersvig in East Greenland (Fig. 54). One of these occurrences, the Blyklippen deposit, was mined in the period 1956-1962. After production of 560000 tonnes ore grading $11.1 \% \mathrm{~Pb}$ and $8.6 \% \mathrm{Zn}$ the deposit was exhausted (Harpøth et al. 1986; Thomassen 2005).

A large porphyry-molybdenum deposit of Miocene age occurs at Malmbjerg (Fig. 54) south of Mestersvig, East Greenland, hosted in an intrusive complex [53]. Ore resource calculations were based on $22 \mathrm{~km}$ of diamond drill cores which indicate a tonnage of 150 million tonnes grading $0.23 \% \mathrm{MoS}_{2}$ and $0.02 \% \mathrm{WO}_{3}$ (Harpøth et al. 1986). A re-evaluation of the deposit was initiated in 2004 and has confirmed the earlier tonnage estimates. A mining company obtained an exploitation licence in 2009 and aims at opening an open pit mine in the near future with a production rate of $c .10000$ tonnes molybdenum per year (MINEX 2007b, 2008b). Other less well-investigated porphyry-molybdenum occurrences exist in the East Greenland Palaeogene volcanic province (Geyti \& Thomassen 1984). 


\section{Petroleum potential of Greenland}

The petroleum potential of Greenland is confined to the sedimentary basins of Phanerozoic age. Onshore, such basins occur in North Greenland, North-East and central East Greenland, and central West Greenland. Offshore, large sedimentary basins are known to occur off both East and West Greenland (Fig. 56). No proven commercial reserves of oil or gas have been found to date (2009), but so far only seven exploration wells have been drilled, six offshore southern West Greenland between latitudes $63^{\circ} 49^{\prime} \mathrm{N}$ and $68^{\circ} \mathrm{N}$, and one onshore, on Nuussuaq at $70^{\circ} 28^{\prime} \mathrm{N}$ in central West Greenland (Christiansen et al. 1997; Pulvertaft 1997). In recent years there has been much interest in petroleum exploration mainly offshore West Greenland, where a number of exploration licences (Fig. 57) have been granted to consortia of both large and small oil companies (F.G. Christiansen, personal communication 2009). In the coming years focus will also be directed towards Baffin Bugt off North-West Greenland. Recent investigations include acquisition of geophysical data (seismic and airborne magnetic/gravity surveys) and seabed sampling. Another main target for future oil and gas exploration will be the shelf areas of North-East Greenland, where geophysical investigations have revealed the existence of a number of large sedimentary basins (Hamann et al. 2005). Based on data from the adjacent onshore areas it may be assumed that source rocks, reservoirs and seals are likely to occur here, and that several play types are present. The geophysical investigations in North-East Greenland both onshore and offshore have up to now only been carried out at reconnaissance level, and the area must still be characterised as essentially unexplored for oil and gas.

The greatly increased interest in recent years for petroleum exploration in Greenland has been supported by its relatively high ranking given by the Arctic Petroleum Appraisal of the United States Geological Survey. Here, North-East Greenland was selected as a prototype for an evaluation of this and similar other areas in the circum-arctic region (F.G. Christiansen, personal communication 2009). The undiscovered resource estimates for both oil and gas are quite high and the Danmarkshavn Basin (see p. 74) in particular is mentioned as a promising area (Gautier et al. 2009). A brief summary of the petroleum-geological features of the main sedimentary basins is given on the follow pages.

\section{Onshore basins} Franklinian Basin, North Greenland $\left(80-83^{\circ} \mathrm{N}\right)$

The Franklinian Basin of North Greenland (see p.45) is the eastern continuation of the Cambrian-Devonian Franklinian Basin of the Canadian Arctic Islands. It consists of a belt of flat-lying, shallow-water carbonate rocks to the south and a northern belt of deep-water folded sedimentary rocks. Good type II (oil-prone) shaly source rocks are known in both Lower-Middle Cambrian and Lower Silurian outer shelf terrigenous and carbonate mudstones. Potential reservoirs include Lower and Middle Cambrian shelf sandstones and Lower Silurian reef and platform margin carbonate build-ups (Stemmerik et al. 1997). The rocks in the north are probably postmature due to the thermal influence of the Ellesmerian orogeny (see p. 49), but oil has been preserved in the southern areas and can now be seen as asphalt residues in pores and fractures in various carbonate rocks. The most promising play involves long-distance migration up-dip from Middle Cambrian source rocks into Lower Cambrian shelf sandstones (Christiansen 1989).

\section{Late Palaeozoic - Mesozoic basins, eastern North Greenland $\left(80-83^{\circ} \mathrm{N}\right)$}

Deposits in the Wandel Sea Basin comprise a succession of sedimentary rocks which were laid down along the northern and north-eastern margin of the Greenland shield (see p. 54). The development spans a period from Early Carboniferous to Palaeogene and includes three main phases of basin formation. The region is transected by a major NW-SE fault zone dividing the area into two blocks with different structural, depositional and thermal histories and hydrocarbon potential (Stemmerik

\footnotetext{
Facing page

Fig. 56. Simplified map showing the onshore and offshore sedimentary basins with petroleum potential of Greenland. Distribution of crustal types can be seen in Fig. 48 A. Ellesmere Island (Canada), Iceland and Svalbard are shown as light brown: undifferentiated. Map based on Henriksen et al. (2000), Chalmers \& Pulvertaft (2001) and Hamann et al. (2005).
} 


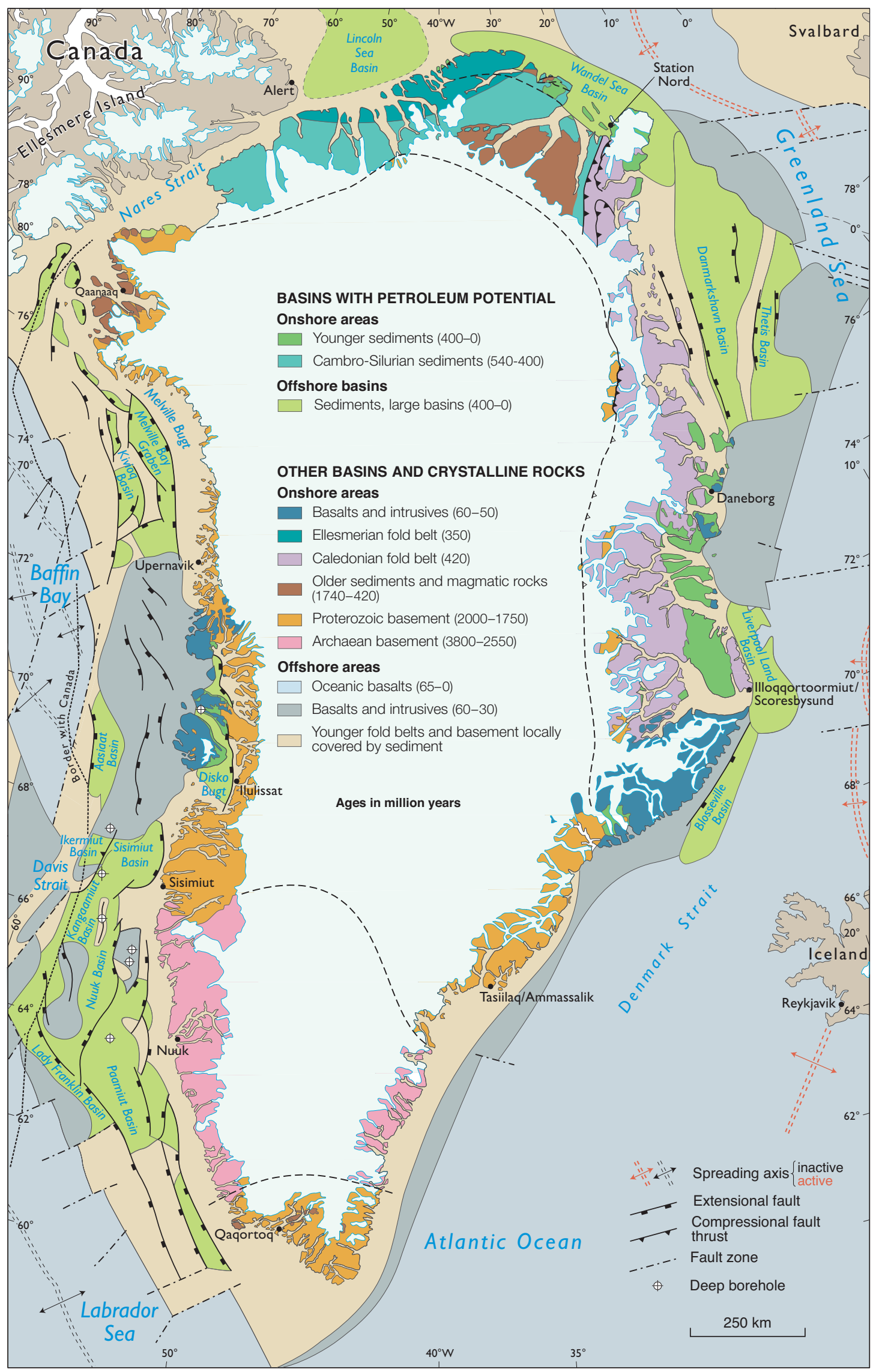


et al. 2000). To the north of the fault zone the prePaleocene sedimentary rocks are considered postmature with respect to petroleum generation and of limited economic interest. This is also likely to be the case on the nearby shelf in eastern North Greenland where a similar sedimentary succession is expected to be present. In contrast, onshore sedimentary rocks in the coastal region south of the fault zone are early mature to immature and therefore there might be a prospective zone in the offshore region along the expected continuation of the fault zone at $c .80^{\circ} \mathrm{N}$ (Fig. 37). Carboniferous and Permian reservoir rocks occur onshore, but source rocks have not been identified.

\section{Late Palaeozoic - Mesozoic rift basins, North-East Greenland $\left(72-76^{\circ} \mathrm{N}\right)$}

The main source rocks in these North-East Greenland basins are: (1) Upper Carboniferous type I-II (highly oil-prone - oil-prone) mudstones with very high generative potential but restricted lateral extent, (2) Upper Permian type II marine mudstones with wide areal extent and high generative potential, and (3) Upper Jurassic (Kimmeridgian) marine mudstones which are mainly gas-prone in onshore outcrops but are likely to be highly interesting oil-prone source rocks on the continental shelf to the east (Hamann et al. 2005).

Reservoir lithologies include Upper Carboniferous fluvial sandstones, Upper Permian carbonates, Upper Jurassic sandstones, and uppermost Jurassic - Lower Cretaceous syn-rift conglomerates and sandstones. The basins are partially fault bounded and tilted, and there are both stratigraphical and structural plays. From regional mapping and maturity considerations an area of about $6000 \mathrm{~km}^{2}$ is considered to have potential prospectivity (Stemmerik et al. 1993), but at present there are no seismic data on which to base a more stringent evaluation. A more detailed understanding of the Jurassic biostratigraphy and depositional models with their potential for source and reservoir lithologies has been gained in recent years (Ineson \& Surlyk 2003; Stemmerik \& Stouge 2004).

\section{Jameson Land Basin, central East Greenland $\left(70^{\circ} 30^{\prime}-72^{\circ} \mathrm{N}\right)$}

The Jameson Land Basin, which extends over an area of about $10000 \mathrm{~km}^{2}$, is covered by a $1798 \mathrm{~km}$ seismic survey, carried out by Atlantic Richfield Company (ARCO) in 1985-89, and consequently is better known than the basins to the north. The structural history of the basin is also different in that rifting began in the Devonian and ended in the mid-Permian; Late Permian - Mesozoic deposition in the basin was governed by thermal subsidence. In addition to the source rock intervals known to the north (Christiansen et al. 1992), an important lowermost Jurassic lacustrine type I-II source rock (highly oil-prone - oil-prone) occurs in Jameson Land (Dam \& Christiansen 1990). Potential reservoirs are Upper Carboniferous (and possibly older) fluvial sandstones, Upper Permian carbonates, and Lower Jurassic deltaic sandstones. Apart from an Upper Carboniferous tilted fault block play, play types are stratigraphic. ARCO stopped their exploration activities at a time when the potential seemed restricted to a Permian play in northwest Jameson Land. Later reinterpretation by GEUS of the seismic data, supplemented by new field work, analyses of source and reservoir rocks and modelling also suggest a possible Lower Jurassic play in central Jameson Land (Dam et al. 1995). The main risk factor in the Jameson Land Basin is the effect of Palaeogene and Neogene uplift that amounts to $2 \mathrm{~km}$ or more (Mathiesen et al. 1995).

\section{Cretaceous-Palaeogene basin, central West Greenland $\left(69-72^{\circ} \mathrm{N}\right)$}

Source rocks in outcrop are mainly gas-prone, but the discovery of surface oil showings in vesicular basalts over a large area extending from northern Disko to southeast Svartenhuk Halvø, as well as the occurrence of oil in three of the five core holes drilled on western Nuussuaq in 1993-1995, prove that source rocks capable of generating oil occur in this region. A $3 \mathrm{~km}$ deep wild-cat well (GRO\#3) was drilled in 1996 on south-western Nuussuaq by the small Canadian company grønArctic Energy Inc. The logs yield some indications of oil and gas, but without giving sufficient background for a continuation of the work (Christiansen et al. 1999). In the region as a whole, biomarkers in the oils indicate that five types of oil are present, with source rocks of Cretaceous-Paleocene age (Bojesen-Koefoed et al. 1999). Reservoirs in the area may be either Cretaceous deltaic sandstones or uppermost Cretaceous - lower Paleocene turbiditic sandstones. 


\section{Offshore basins}

\section{North-East Greenland shelf $\left(75-80^{\circ} \mathrm{N}\right)$}

An area of more than $125000 \mathrm{~km}^{2}$ offshore North-East Greenland is believed to have considerable petroleum potential. This view is based on extrapolation from the adjacent onshore area, where oil source rocks are present at several levels, and also from the northern North Sea, West Norwegian shelf and south-west Barents Sea,

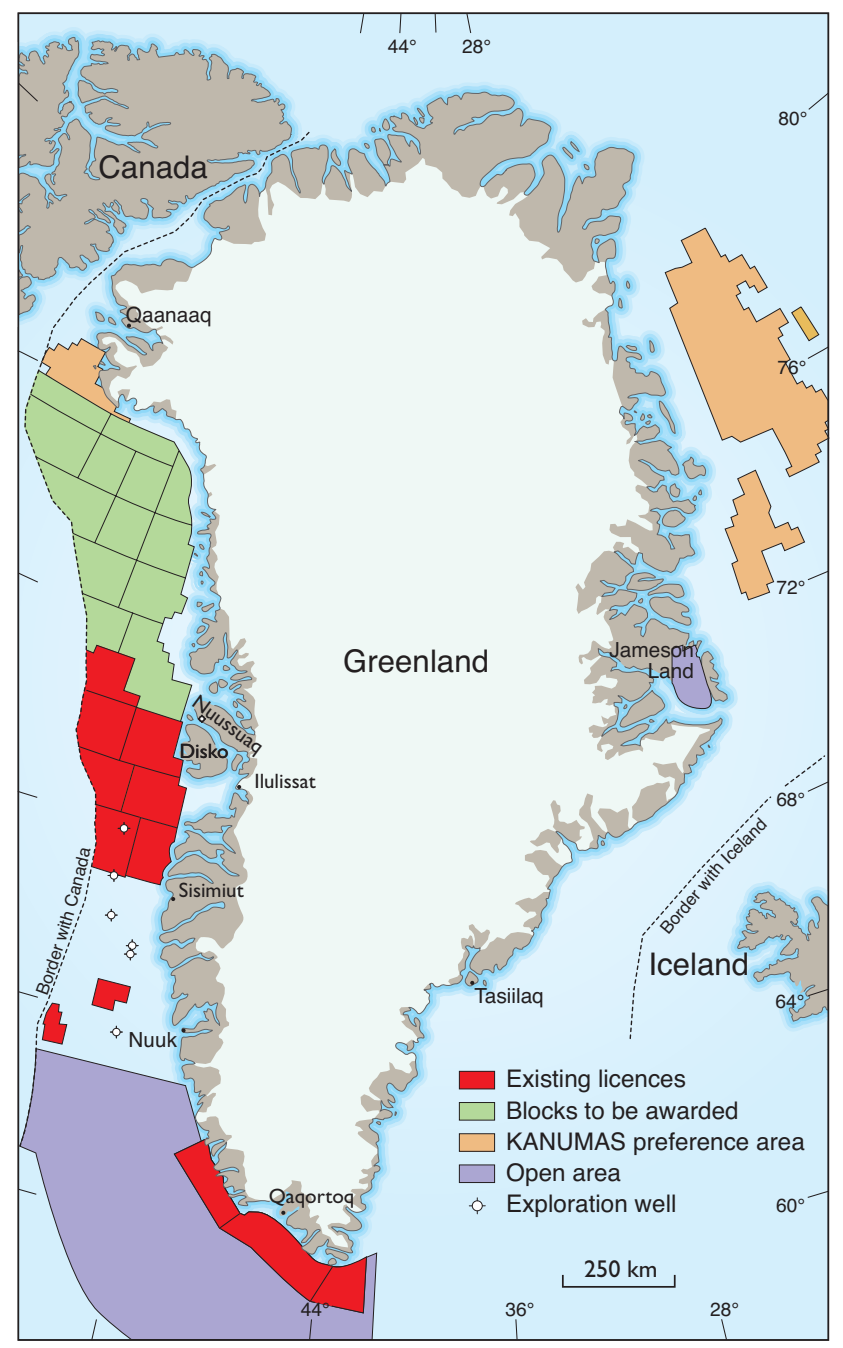

Fig. 57. Summary map of Greenland showing the state of concession agreements for hydrocarbon exploration at the end of 2008 (awarded licence areas shown in red). Licensing rounds were held in 2002, 2004, 2006 and 2007. Licences in two smaller areas west of Nuuk were awarded in 2003 and 2005, and a large region west of Disko was awarded in seven block areas in 2007 to four groups of oil companies. The green areas are blocks to be awarded in connection with a licence call round in 2010. The violet areas are covered by a so-called 'open-door' policy where oil companies can apply for concessions at any time. The yellow areas show where a group of companies (the KANUMAS companies) have preferential positions, but where exploration is not expected to take place in the near future. From Bureau of Minerals and Petroleum, Nuuk. areas which were contiguous with the North-East Greenland shelf before the opening of the Greenland-Norwegian Sea (Tsikalas et al. 2005). The KANUMAS reconnaissance seismic survey of the shelf area confirmed that thick sedimentary basins occur on the shelf comprising possible Devonian to Neogene deposits with a thickness of up to $c .13 \mathrm{~km}$ (Hamann et al. 2005). Interpretation of the gravity and seismic data furthermore indicates that Upper Carboniferous - Lower Permian salt deposits are widespread between $c .77-79^{\circ} \mathrm{N}$ (Stemmerik \& Worsley 2005), as shown on the geological map and on Fig. 50A. The East Greenland succession on the shelf almost certainly includes Upper Jurassic and other source rocks. In the Danmarkshavn Basin (see Fig. 50B) the Jurassic sediments have been buried deeply enough to generate hydrocarbons. The succession is expected to include extensive, excellent quality source rocks, and trap structures include large-scale fault blocks (Hamann et al. 2005). Possible source rocks are correlatives of the following onshore occurrences: 1) organic-rich marine shales from the Upper Permian Ravnefjeld Formation considered to be good to excellent source rocks (Christiansen et al. 1993), 2) marine Jurassic shales of Kimmeridgian age known as the Hareelv Formation in central East Greenland (Christiansen et al. 1992, 1993; Surlyk 2003) and other equivalents to the world class Upper Jurassic source rocks known from the North Atlantic region (Christiansen et al. 1993; Hamann et al. 2005), 3) Upper Triassic - Lower Jurassic lacustrine organic-rich shales from the Kap Stewart Formation in central East Greenland and 4) other source rocks may be found in lacustrine deposits of Late Palaeozoic age and from equivalents of Middle Jurassic coal deposits found onshore North-East Greenland.

The Arctic Petroleum Appraisal of the United States Geological Survey has rated the North-East Greenland shelf region an area with major potential for oil and gas; most of the undiscovered resources are likely to be in the Danmarkshavn Basin (Gautier et al. 2009).

\section{Liverpool Land Basin, central East Greenland $\left(69^{\circ} 30^{\prime}-72^{\circ} \mathrm{N}\right)$}

Up to $6 \mathrm{~km}$ of Cenozoic sedimentary rocks unconformably overlie block-faulted Upper Palaeozoic Mesozoic sedimentary rocks in the inner (landward) part of the Liverpool Land Basin. In the outer part of this basin oceanic crust occurs beneath a thick wedge of Neogene and Plio-Pleistocene sedimentary rocks (H.C. Larsen 1990; Hamann et al. 2005). Source rocks are likely to 
occur at several levels in the pre-Cenozoic sedimentary rocks, but are probably postmature. Nothing can be deduced about the nature of mudstones in the Palaeogene. Only a few weak structures have been observed in the Cenozoic section, and the best traps are likely to be stratigraphic.

\section{Blosseville Kyst Basin, East Greenland $\left(67-69^{\circ} 30^{\prime} \mathrm{N}\right)$}

Only the post-basalt Cenozoic sedimentary rocks in the Blosseville Kyst Basin are considered likely to have any potential for petroleum, since any sedimentary rocks underlying the basalts will be thermally postmature. The outermost sedimentary rocks overlie oceanic crust. Trap structures occur where the sediments drape buried volcanic edifices, and it is likely that there are also stratigraphic traps. Submarine fan sandstones fed from the land areas to the north and north-west are likely to be the best potential reservoirs in the area. Source rocks are most likely to occur in the Eocene - Lower Oligocene sedimentary rocks, which were deposited at a time when the area had only limited connections with the early Atlantic Ocean, a factor that would favour oxygen-deficient conditions (H.C. Larsen 1985).

\section{West Greenland}

Southern West Greenland was the first offshore area where companies were awarded exclusive licenses for hydrocarbon exploration. About $37000 \mathrm{~km}$ of seismic data were acquired in the shallower parts of the area (water depths $<500 \mathrm{~m}$ ) in the early 1970s, and five wells were drilled. One well (Kangâmiut-1, c. $66^{\circ} \mathrm{N}$ ) encountered wet gas (Chalmers et al. 1995), but the others were dry. With hindsight it can be seen that only the Kangâmiut-1 well tested a viable structure (Chalmers \& Pulvertaft 1993). In the 1990s exploration was resumed in the region, and more than $23000 \mathrm{~km}$ of additional seismic data were acquired, extending knowledge of the geology into deeper water areas which appear to be the most prospective. A sixth well (Qulleq-1, west of Nuuk) was drilled by Statoil in 2000; this yielded important new stratigraphic information but was dry (Christiansen et al. 2001). In the last ten years, interest for oil and gas exploration in West Greenland has been driven by the documentation of live petroleum systems onshore between $70^{\circ} 12^{\prime}$ and $71^{\circ} 29^{\prime} \mathrm{N}$ (Bojesen-Koefoed et al. 1999), the identification of large sedimentary basins and structures offshore, and high oil prices. A number of licensing rounds have been held with the result that at present (2009) 11 blocks covering more than $125000 \mathrm{~km}^{2}$ have been awarded to company consortia (Fig. 57; F.G. Christiansen, personal communication 2009). In some areas outside the licensing areas an 'open door' policy has been introduced in order to encourage data acquisition while accepting higher risk. The result of the last ten years' exploration activity is that there is now a modern regional data coverage of the region between $c .62^{\circ}$ and $76^{\circ} \mathrm{N}$, including more than $50000 \mathrm{~km}$ non-exclusive seismic data and also airborne magnetic and gravity data covering very large areas.

\section{South and South-West Greenland (c. $\left.57-62^{\circ} \mathrm{N}\right)$}

The shelf south of $62^{\circ} \mathrm{N}$ is relatively narrow with a steep, locally unstable, slope towards the ocean floor in the Labrador Sea. Seismic data coverage is sparse, but new data acquisition in the recently awarded licence blocks (Fig. 57), combined with investigations within the scope of the Danish Continental Shelf Programme, will provide a greatly improved data base in coming years.

With the limited existing data base, assessment of the potential for oil and gas and possible play types is very speculative. However, there are indications of Mesozoic rifting in the few available seismic lines, and a $141 \mathrm{Ma}$ old onshore coast-parallel dyke swarm bears witness of the initiation of rifting in the earliest Cretaceous (Watt 1969; L.M. Larsen et al. 2009).

\section{Southern West Greenland $\left(c .62-68^{\circ} \mathrm{N}\right)$}

This region is the site of extensive and deep basins with thick successions of Mesozoic-Cenozoic sediments. Knowledge of the region is based not only on extensive seismic, magnetic and gravity surveys and seabed sampling but also on the data obtained from five wells drilled in the late 1970s:

Nukik-1, $65^{\circ} 32^{\prime} \mathrm{N}, 54^{\circ} 46^{\prime} \mathrm{W}$

Nukik-2, $65^{\circ} 38^{\prime} \mathrm{N}, 54^{\circ} 46^{\prime} \mathrm{W}$

Kangâmiut- $1,66^{\circ} 09^{\prime} \mathrm{N}, 56^{\circ} 11^{\prime} \mathrm{W}$

Ikermiut $-1,66^{\circ} 56^{\prime} \mathrm{N}, 56^{\circ} 35^{\prime} \mathrm{W}$

Hellefisk- $1,67^{\circ} 53^{\prime} \mathrm{N}, 56^{\circ} 44^{\prime} \mathrm{W}$

and a sixth well drilled in 2000 :

Qulleq-1,634ำ $\mathrm{N}, 57^{\circ} 27^{\prime} \mathrm{W}$

No well penetrated the deepest sediments in the region; the oldest sediments encountered being those at the base 
of the Qulleq-1 well which are of Santonian age (Christiansen et al. 2001). In consequence interpretation of the age and lithologies of the deepest sediments is based largely on analogies with the Labrador shelf where many more wells have been drilled.

A prerequisite for petroleum prospectivity is the presence of a good source rock. Although none of the wells sampled a good source rock, the live oil showings in vuggy Paleocene basalts on the Nuussuaq peninsula prove that such rocks exist in central West Greenland (Christiansen et al. 1996; Bojesen-Koefoed et al. 1999). The source rocks most likely to occur offshore southern West Greenland are 1) lacustrine mudstones and coals in the Lower Cretaceous syn-rift Kitsissut and Appat sequences, 2) Cenomanian-Turonian organic-rich mudstones at or near the base of the post-rift Kangeq sequence. These are correlatives of the marine Cenomanian-Turonian source rock interpreted as having given rise to the Itilli oil type, one of the five oil types occurring in the live oil showings on Nuussuaq (Bojesen-Koefoed et al. 1999), 3) Paleocene deltaic mudstones, correlatives of the Cretaceous-Paleocene source rocks in central West Greenland from which three of the five oil types in live showings was derived (Bojesen-Koefoed et al. 1999) and 4) mudstones deposited distally relative to prograding Palaeogene sequences that were described by Dalhoff et al. (2003)

The main play type involves block-faulted and tilted reservoir sandstones of the Kitsissut and Appat sequences with oil (and/or gas) derived from Cenomanian-Turonian source rocks and sealed by Cenomanian-Campanian mudstones of the Kangeq Formation or Paleocene mudstones that drape the fault blocks (Chalmers et al. 1993). Anticlinal structures generated locally by transpression along the Ungava Fracture Zone (Fig. 48B) provide another potential for traps. New interpretations of the Paleocene-mid-Eocene seismic sequences combined with stratigraphic correlations with well data have shown that within the Palaeogene succession there are sandy basinfloor fans and turbidite channel complexes encased in basin mudstones that could act as stratigraphic traps (Dalhoff et al. 2003).

From the Kangâmiut-1 well wet gas (up to C5) was reported by Chalmers et al. (1995), but the drill stem test produced only water from the drilling mud, not formation fluid (Skaarup 2007). Thus the possibility remains that a significant, untested, hydrocarbon field exists in the Kangâmiut structure.

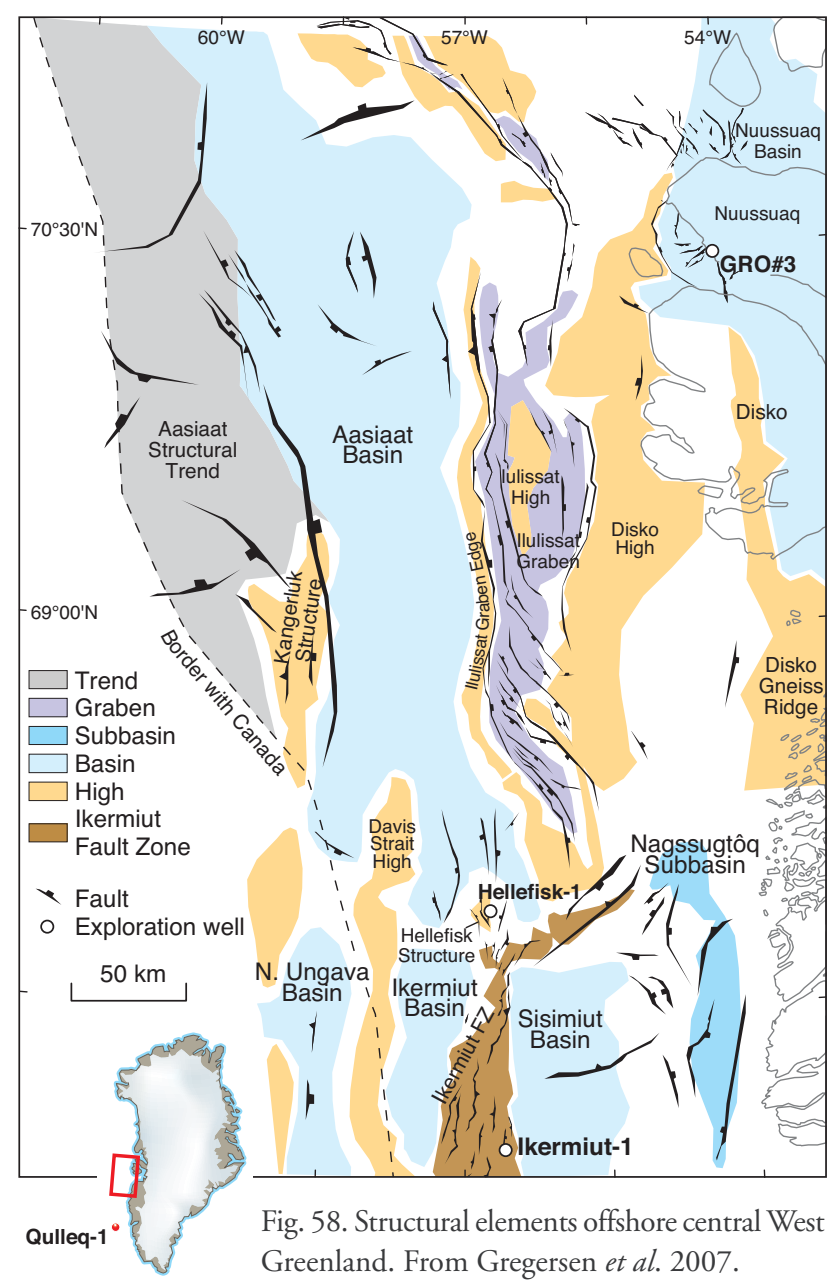

\section{Central West Greenland (c. 68-73 $\left.{ }^{\circ} \mathrm{N}\right)$}

In this region Palaeogene basalts are widespread which hampers interpretation of Early Paleocene and older sediments. However, since the 1:2 500000 map was printed in 1995, a wealth of new data has been acquired in this region, allowing greatly improved interpretations and the compilation of an overview map showing the main structural elements in the area (Fig. 58; Gregersen et al. 2007). Interest in acquiring new data in this area was stimulated by the discovery of live oil seeps in the adjacent onshore area (Christiansen et al. 1996; Bojesen-Koefoed et al. 1999). Five oil types have been identified in these seeps, three likely to have been derived from Cretaceous and Paleocene prodelta source rocks and a fourth, the Itilli oil type, from dysoxic to anoxic marine shales, probably of Cenomanian-Turonian or older age. All these source rocks can be expected to occur in the offshore region.

The new data have clearly revealed the existence of a number of deep basins with Mesozoic and Cenozoic sedimentary successions and also several large structures and 
closures that could provide traps (Gregersen \& Bidstrup 2008). The structures were initiated during Early to midCretaceous rifting. Syn-rift sediments deposited during this phase are likely to be sandstones with potential reservoir properties. During the subsequent Late Cretaceous quiet phase, a thick basinal mudstone unit was deposited, the equivalent of the Kangeq sequence farther south. This may well contain source rocks that correlate with the source of the Itilli oil type. Renewed tectonic activity in the latest Cretaceous - Early Paleocene caused uplift and formation of large structures, some of which could provide traps for hydrocarbons. Prodelta Paleocene source rocks equivalent to the suggested sources of three of the oil types identified in onshore seeps could be present. Late Paleocene-Eocene transpression related to the Ungava Fracture Zone (Fig. 49B) led to the formation of anticlinal structures that have a potential as traps. Finally, during the Eocene and especially during the late Miocene and Pliocene, the offshore basins subsided rapidly, and large sedimentary wedges prograded towards the west and south.

Direct hydrocarbon indicators (DHIs) such as bright spots in some seismic lines are encouraging signs that this segment of Greenland waters hosts live petroleum systems (Gregersen et al. 2007).

\section{North-West Greenland $\left(73-77^{\circ} \mathrm{N}\right)$}

The region is the site of some of the largest structures and deepest rift basins anywhere offshore West Greenland (Fig. 53; Whittaker et al. 1997). This was first shown by the results of the KANUMAS reconnaissance seismic survey carried out in 1992; later public domain surveys carried out in north-east Baffin Bay in 2000 have provided a more detailed picture of this part of the rift system (Gregersen 2008). In addition, recent gravity and magnetic surveys have supplemented knowledge of the deep basins and structural highs.

No wells have been drilled in this region, so interpretation of the age and character of the sedimentary fill of the basins is based on analogies with onshore areas in north-east Canada (Bylot Island) and central West Greenland (the Nuussuaq Basin), and with the Labrador Sea. The bulk of the up to $12 \mathrm{~km}$ thick sedimentary fill is likely to be of Cretaceous-Neogene age. Rifting probably started in the Early Cretaceous (Whittaker et al. 1997), and sandstones deposited in the early syn-rift stage could be good reservoirs for hydrocarbons. During subsequent thermal subsidence a transgressive unit was deposited that is analogous to the latest Cenomanian-
Turonian Kanguk Formation in the Canadian Arctic Islands. Near the base of this formation there are oilprone, marine shale source rocks which, however, in this area are thermally immature (Núñez-Betulu 1993). If the analogy to the Kanguk Formation holds, a similar marine source rock can be expected near the base of the transgressive unit in north-east Baffin Bay. Support for this suggestion has been obtained by submitting samples of the source rock shales in the Kanguk Formation to hydrous pyrolysis. This yielded bitumen that shares a number of important characteristics with the Itilli oil type occurring in vuggy basalts and fractures onshore central West Greenland (Bojesen-Koefoed et al. 2004). The Itilli oil type was generated from marine source rocks of presumably Cenomanian-Turonian age (Bojesen-Koefoed et al. 1999). Marine source rocks usually have a wide areal distribution, so this source rock may well occur offshore north of $73^{\circ} \mathrm{N}$ and even tie up physically with the Kanguk Formation source rocks. The mudstones of the transgressive unit could also provide a seal to hydrocarbons trapped in the underlying sandstones in tilted fault blocks and anticlinal inversion structures.

Three of the other oil types described by BojesenKoefoed et al. (1999) were derived from Cretaceous and Paleocene prodelta source rocks. Similar source rocks could also occur locally in north-east Baffin Bay. Hydrocarbons generated from these source rocks could be trapped in the cores of anticlines formed during inversion and transpression, particularly in the northern part of the area. Reservoir could be provided by depositional systems such as turbidite fan lobes shed off the inversion highs (Whittaker et al. 1997).

\section{Western North Greenland (north of $80^{\circ} \mathrm{N}$ )}

Lincoln Sea (Lincoln Hav on the map) north of North Greenland and Ellesmere Island (Canada) contains an extensive shelf region (almost $500 \times 200 \mathrm{~km}$ ) with water depths below $500 \mathrm{~m}$. The sea is normally covered by thick multi-year sea ice, and our present knowledge of the subsurface geology stems from two recent seismic refraction profiles (Dahl-Jensen et al. 2006) and earlier magnetic and gravity data. Interpretation of the geophysical data suggests that the basin underlying the Lincoln Sea comprises a sedimentary sequence with a thickness of more than $10 \mathrm{~km}$.

Based on modelling from the seismic data it is assumed that the sedimentary succession in the Lincoln Sea Basin is comparable with the deposits in the Mesozoic-Cenozoic Sverdrup Basin of Arctic Canada. By comparison with 
known petroleum indications in the Sverdrup Basin it is inferred that strata in the Lincoln Sea Basin may contain source rocks of marine shales of mid-Triassic - latest Jurassic and also marine type 2 source rocks of Upper Jurassic age (K. Sørensen, personal communication 2009). Mesozoic reservoir rocks may be widespread and intervening shales could form potential seals.

\section{Acknowledgements}

The map was compiled in 1994-95 and printed in 1995. The onshore areas of the map sheet were compiled by J.C. Escher with contributions from North and East Greenland by H.-J. Bengaard and N. Henriksen. The offshore areas were compiled by T.C.R. Pulvertaft, and the final compilation and legend design was carried out by J.C. Escher (see also map legend).

This second revised edition of the descriptive text was prepared in 2009. Comments to the various sections have been provided by:

The Greenland Precambrian shield: A.A. Garde The Gardar Province: L.M. Larsen

Thule Supergroup: P.R. Dawes
Carbonatites, kimberlites and associated rocks:

L.M. Larsen and T.F.D. Nielsen

The Franklinian Basin: J.R. Ineson

Devonian to Cenozoic basins in North-East Greenland:

S. Piasecki

Cretaceous-Palaeogene basins in West Greenland:

G. Dam, G.K. Pedersen and M. Sønderholm

Palaeogene volcanic rocks and intrusions:

L.M. Larsen and T.F.D. Nielsen

Quaternary sediments and glaciology: O. Bennike

Offshore geology: T. Dahl-Jensen, T. Funck and Ø. Engen Mineral deposits: $K$. Secher

Petroleum potential: F.G. Christiansen, J.A. Chalmers, U. Gregersen, K. Sørensen and N. Skaarup.

Valuable comments and suggestions from other colleagues at the Survey are also gratefully acknowledged.

Finally, the bulletin has benefited from thorough reviews by C.R.L. Friend (UK), H. Stendal (Greenland) and G.N. Oakey (Canada), whose suggestions for improvements of text and illustrations have been incorporated with thanks. 
Allaart, J.H. 1975: Geological map of Greenland, 1:500 000, Sheet 1, Sydgrønland. Copenhagen: Geological Survey of Greenland.

Andersen, J.C.Ø., Rasmussen, H., Nielsen, T.D.F. \& Rønsbo, J.G. 1998: The triple group and the Platinova gold and palladium reefs in the Skaergaard Intrusion: stratigraphic and petrographic relations. Economic Geology 93, 488-509.

Andersen, S., Bailey, J.C. \& Bohse, H. 1981: Zr-Y-U stratigraphy of the karkortokite-lujavrite sequence, southern Ilímaussaq intrusion. In: Bailey, J.C., Larsen, L.M. \& Sørensen, H. (eds): The Ilímaussaq intrusion, South Greenland. Rapport Grønlands Geologiske Undersøgelse 103, 69-76.

Andresen, A., Hartz, E.H. \& Vold, J. 1998: A late orogenic extensional origin for the infracrustal gneiss domes of the East Greenland Caledonides $\left(72-74^{\circ} \mathrm{N}\right)$. Tectonophysics 285, 353-369.

Appel, P.W.U. 1991: The Isua iron ore deposit at Isukasia, West Greenland. Open File Series Grønlands Geologiske Undersøgelse 91/3, 31 pp.

Appel, P.W.U. 1992: Chromite in the Fiskenæsset stratiform anorthosite complex, West Greenland. Open File Series Grønlands Geologiske Undersøgelse 92/5, 16 pp.

Ashwal, L.D., Jacobsen, S.B., Myers, J.S., Kalsbeek, F. \& Goldstein, S.J. 1989: Sm-Nd age of the Fiskenæsset Anorthosite Complex, West Greenland. Earth and Planetary Science Letters 91, 261-270.

Balkwill, H.R., McMillan, N.J., MacLean, B., Williams, G.L. \& Srivastava, S.P. 1990: Geology of the Labrador Shelf, Baffin Bay and Davis Strait. In: Keen, M.J. \& Williams, G.L. (eds): Geology of the continental margin of eastern Canada. The geology of North America I-1, 293-348. Boulder, Colorado: Geological Society of America (also Geology of Canada 2, Geological Survey of Canada).

Bell, J.S. \& Howie, R.D. 1990: Paleozoic geology. In: Keen, M.J. \& Williams, G.L. (eds): Geology of the continental margin of eastern Canada. Geology of Canada 2, 141-165 (also The geology of North America I-1, Geological Society of America).

Bendix-Almgreen, S.E. \& Peel, J.S. 1974: Early Devonian vertebrates from Hall Land, North Greenland. Rapport Grønlands Geologiske Undersøgelse 65, 13-16.

Bengaard, H.-J. \& Henriksen, N. 1986: Geological map of Greenland, 1:500 000, Sheet 8, Peary Land. Copenhagen: Geological Survey of Greenland.

Bennike, O., Björck, S. \& Lambeck, K. 2002: Estimates of South Greenland late-glacial ice limits from a new relative sea level curve. Earth and Planetary Science Letters 197, 171-186.

Berger, D. \& Jokat, W. 2008: A seismic study along the East Greenland margin from $72^{\circ} \mathrm{N}$ to $77^{\circ} \mathrm{N}$. Geophysical Research International 174, 733-748.

Bernstein, S., Leslie, A.G. \& Higgins, A.K. 2000: Tertiary alkaline volcanics in the Nunatak region, Northeast Greenland: new observations and comparison with Siberian maymechites. Lithos 53, 1-20.
Berthelsen, A. 1960: Structural studies in the Pre-Cambrian of western Greenland. Part II. Geology of Tovqussap nunâ. Bulletin Grønlands Geologiske Undersøgelse 25, 223 pp. (also Meddelelser om Grønland 123(1)).

Berthelsen, A. \& Henriksen, N. 1975: Geological map of Greenland, 1:100 000, Ivigtut 61 V.1 Syd. Descriptive text, 169 pp. Copenhagen: Geological Survey of Greenland.

Bird, D.K., Brooks, C.K., Gannicott, R.A. \& Turner, P. 1991: A gold-bearing horizon in the Skaergaard intrusion, East Greenland. Economic Geology 86(5), 1083-1092.

Birkelund, T. \& Håkansson, E. 1983: The Cretaceous of North Greenland - a stratigraphic and biogeographic analysis. Zitteliana 10, 7-25.

Bizzarro, M., Simonetti, A., Stevenson, R.K. \& David, J. 2002: Hf isotope evidence for a hidden mantle reservoir. Geology 30, 771-774.

Blichert-Toft, J., Rosing, M.T., Lescher, C.E. \& Chauvel, C. 1995: Geochemical constraints on the origin of the Late Archaean Skjoldungen alkaline igneous province, SE Greenland. Journal of Petrology 36, 515-561.

Blom, H. 1999: Vertebrate remains from Upper Silurian - Lower Devonian beds of Hall Land, North Greenland. Geology of Greenland Survey Bulletin 182, 80 pp.

Bojesen-Koefoed, J.A., Christiansen, F.G., Nytoft, H.P. \& Pedersen, A.K. 1999: Oil seepage onshore West Greenland: evidence of multiple source rocks and oil mixing. In: Fleet, A.J. \& Boldy, S.A.R. (eds): Petroleum geology of Northwest Europe: Proceedings of the 5th conference, 305-314. London: Geological Society.

Bojesen-Koefoed, J.A., Nytoft, H.P. \& Christiansen, F.G. 2004: Age of oils in West Greenland: Was there a marine seaway between Greenland and Canada. Geological Survey of Denmark and Greenland Bulletin 4, 49-52.

Bondam, J. 1991: The Ivigtut cryolite deposit in South Greenland. Short note on recent geoscientific developments. Open File Series Grønlands Geologiske Undersøgelse 91/4, 29 pp.

Bondam, J. 1995: The Ilímaussaq nepheline syenite complex in South Greenland. A general overview of exploratory activities and environmental studies. Open File Series Grønlands Geologiske Undersøgelse 95/2, 121 pp.

Bondesen, E. 1970: The stratigraphy and deformation of the Precambrian rocks of the Grænseland area, South-West Greenland. Bulletin Grønlands Geologiske Undersøgelse 86, 210 pp. (also Meddelelser om Grønland 185(1)).

Bridgwater, D., McGregor, V.R. \& Myers, J.S. 1974: A horizontal tectonic regime in the Archaean of Greenland and its implications for early crustal thickening. Precambrian Research 1, 179-197.

Brooks, C.K., Fawcett, J.J. \& Gittins, J. 1976: Caledonian magmatic activity in south-eastern Greenland. Nature 260, 694-695.

Brooks, C.K., Pedersen, A.K. \& Rex, D.C. 1979: The petrology and 
age of alkaline mafic lavas from the nunatak zone of central East Greenland. Bulletin Grønlands Geologiske Undersøgelse 133, 28 pp.

Brooks, C.K., Fawcett, J.J., Gittins, J. \& Rucklidge, J.C. 1981: The Batbjerg complex, East Greenland: a unique ultrapotassic Caledonian intrusion. Canadian Journal of Earth Sciences 18, 274-285.

Brooks, C.K., Tegner, C., Stein, H. \& Thomassen, B. 2004: Re-Os and ${ }^{40} \mathrm{Ar} /{ }^{39} \mathrm{Ar}$ ages of porphyry molybdenum deposits in the East Greenland volcanic-rifted margin. Economic Geology 99, $1215-1222$

Brown, P.E., Parsons, I. \& Becker, S.M. 1987: Peralkaline volcanicity in the Arctic Basin - the Kap Washington Volcanics, petrology and palaeotectonics. Journal of the Geological Society (London) 144, 707-715.

Brueckner, H.K., Gilotti, J.A. \& Nutman, A.P. 1998: Caledonian eclogite facies metamorphism of Early Proterozoic protoliths from the North-East Greenland eclogite province. Contributions to Mineralogy and Petrology 130, 103-120.

Cande, S.C. \& Kent, D.V. 1995: Revised calibration of the geomagnetic polarity timescale for the Late Cretaceous and Cenozoic. Journal of Geophysical Research 100(B4), 6093-6095.

Chadwick, B. \& Garde, A.A. 1996: Palaeoproterozoic oblique plate convergence in South Greenland: a re-appraisal of the Ketilidian orogen. In: Brewer, T.S. (ed.): Precambrian crustal evolution in the North Atlantic region. Geological Society Special Publication (London) 112, 179-196.

Chadwick, B., Dawes, P.R., Escher, J.C., Friend, C.R.L., Hall, R.P., Kalsbeek, F., Nielsen, T.F.D., Nutman, A.P., Soper, N.J. \& Vasudev, V.N. 1989: The Proterozoic mobile belt in the Ammassalik region, South-East Greenland (Ammassalik mobile belt): an introduction and re-appraisal. In: Kalsbeek, F. (ed.): Geology of the Ammassalik region, South-East Greenland. Rapport Grønlands Geologiske Undersøgelse 146, 5-12.

Chalmers, J.A. 1991: New evidence on the structure of the Labrador Sea/Greenland continental margin. Journal of the Geological Society (London) 148, 899-908.

Chalmers, J.A. 1997: The continental margin off southern Greenland: along-strike transition from an amagnetic to a volcanic margin. Journal of the Geological Society (London) 154, 571-576.

Chalmers, J.A. \& Laursen, K.H. 1995: Labrador Sea: the extent of continental and oceanic crust and the timing of the onset of seafloor spreading. Marine and Petroleum Geology 12, 205-217.

Chalmers, J.A. \& Pulvertaft, T.C.R. 1993: The southern West Greenland continental shelf - was petroleum exploration abandoned prematurely? In: Vorren, T.O. et al. (eds): Arctic geology and petroleum potential. Norsk Petroleumsforening Special Publication 2, 55-66.

Chalmers, J.A. \& Pulvertaft, T.C.R. 2001: Development of the continental margins of the Labrador Sea: a review. In: Wilson, R.C.L. et al. (eds): Non-volcanic rifting of continental margins: a comparison of evidence from land and sea. Geological Society Special Publication (London) 187, 77-105.

Chalmers, J.A., Pulvertaft, T.C.R., Christiansen, F.G., Larsen, H.C., Laursen, K.H. \& Ottesen, T.G. 1993: The southern West Greenland continental margin: rifting history, basin development and petroleum potential. In: Parker, J.R. (ed.): Petroleum geology of
Northwest Europe: Proceedings of the 4th conference, 915-931. London: Geological Society.

Chalmers, J.A., Dahl-Jensen, T., Bate, K.J. \& Whittaker, R.C. 1995: Geology and petroleum prospectivity of the region offshore southern West Greenland - a summary. Rapport Grønlands Geologiske Undersøgelse 165, 13-21.

Chalmers, J.A., Pulvertaft, T.C.R., Marcussen, C. \& Pedersen, A.K. 1999: New insight into the structure of the Nuussuaq Basin, central West Greenland. Marine and Petroleum Geology 16, 197-224.

Chian, D. \& Louden, K.E. 1994: The continent-ocean crustal transition across the southwest Greenland margin. Journal of Geophysical Research 99(B5), 9117-9135.

Christiansen, F.G. (ed.) 1989: Petroleum geology of North Greenland. Bulletin Grønlands Geologiske Undersøgelse 158, 92 pp.

Christiansen, F.G., Marcussen, C., Larsen, H.C. \& Stemmerik, L. 1991: Petroleum potential of Jameson Land, East Greenland, 61 pp., 11 encl. Unpublished report, Geological Survey of Greenland, Copenhagen (in archives of Geological Survey of Denmark and Greenland, GEUS Report File 16975).

Christiansen, F.G., Dam, G., Piasecki, S. \& Stemmerik, L. 1992: A review of Upper Palaeozoic and Mesozoic source rocks from onshore East Greenland. In: Spencer, A.M. (ed.): Generation, accumulation and production of Europe's hydrocarbons. Special Publication of the European Association of Petroleum Geoscientists 2, 151-161.

Christiansen, F.G., Larsen, H.C., Marcussen, C., Piasecki, S. \& Stemmerik, L. 1993: Late Paleozoic plays in East Greenland. In: Parker, J.R. (ed.): Petroleum geology of Northwest Europe: Proceedings of the 4th conference, 657-666. London: Geological Society.

Christiansen, F.G., Marcussen, C. \& Chalmers, J.A. 1995: Geophysical and petroleum geological activities in the Nuussuaq - Svartenhuk Halvø area 1994: promising results for an onshore exploration potential. Rapport Grønlands Geologiske Undersøgelse 165, 32-41.

Christiansen, F.G., Bojesen-Koefoed, J., Dam, G., Nytoft, H.P., Pedersen, A.K., Larsen, L.M. \& Pulvertaft, T.C.R. 1996: The Marraat oil discovery on Nuussuaq, West Greenland: evidence for a latest Cretaceous - earliest Tertiary oil source rock in the Labrador Sea - Melville Bay region. Bulletin of the Canadian Society of Petroleum Geologists 44, 39-54.

Christiansen, F.G., Boesen, A., Dalhoff, F., Pedersen, A.K., Pedersen, G.K., Riisager, P. \& Zinck-Jørgensen, K. 1997: Petroleum geological activities onshore West Greenland in 1996, and drilling of a deep exploration well. Geology of Greenland Survey Bulletin 176, 17-23.

Christiansen, F.G. et al. 1999: Petroleum geological activities in West Greenland in 1998. Geology of Greenland Survey Bulletin 183, 46-56.

Christiansen, F.G. et al. 2001: Petroleum geological activities in West Greenland in 2000. Geology of Greenland Survey Bulletin 189, 24-33.

Clarke, D.B. \& Pedersen, A.K. 1976: Tertiary volcanic province of West Greenland. In: Escher, A. \& Watt, W.S. (eds): Geology of Greenland, 364-385. Copenhagen: Geological Survey of Greenland. 
Clarke, D.B. \& Upton, B.G.J. 1971: Tertiary basalts of Baffin Island: field relations and tectonic setting. Canadian Journal of Earth Sciences 8, 248-258.

Clemmensen, L.B. 1980a: Triassic rift sedimentation and palaeogeography of central East Greenland. Bulletin Grønlands Geologiske Undersøgelse 136, 72 pp.

Clemmensen, L.B. 1980b: Triassic lithostratigraphy of East Greenland between Scoresby Sund and Kejser Franz Josephs Fjord. Bulletin Grønlands Geologiske Undersøgelse 139, 56 pp.

Clemmensen, L.B. 1988: Aeolian morphology preserved by lava cover, the Precambrian Mussartût Member, Eriksfjord Formation, South Greenland. Bulletin of the Geological Society of Denmark 37, 105-116.

Clemmensen, L.B. \& Jepsen, H.F. 1992: Lithostratigraphy and geological setting of Upper Proterozoic shoreline-shelf deposits, Hagen Fjord Group, eastern North Greenland. Rapport Grønlands Geologiske Undersøgelse 157, 27 pp.

Collinson, J.D., Bevins, R.E. \& Clemmensen, L.B. 1989: Post-glacial mass flow and associated deposits preserved in palaeovalleys: the Late Precambrian Morænesø Formation, North Greenland. Meddelelser om Grønland Geoscience 21, 26 pp.

Collinson, J.D., Kalsbeek, F., Jepsen, H.F., Pedersen, S.A.S. \& Upton, B.G.J. 2008: Paleoproterozoic and Mesoproterozoic sedimentary and volcanic successions in the northern parts of the East Greenland Caledonian orogen and its foreland. In: Higgins, A.K., Gilotti, J.A. \& Smith, M.P. (eds): The Greenland Caledonides: evolution of the northeast margin of Laurentia. Geological Society of America Memoir 202, 73-89.

Connelly, J.N. \& Mengel, F.C. 2000: Evolution of Archaean components in the Palaeoproterozoic Nagssugtoqidian orogen, West Greenland. Geological Society of America Bulletin 112, 747-763.

Connelly, J.N. \& Thrane, K. 2005: Rapid determination of Pb isotopes to define Precambrian allochthonous domains: an example from West Greenland. Geology 33, 953-956.

Connelly, J.N., van Gool, J.A.M. \& Mengel, F.C. 2000: Temporal evolution of a deeply eroded orogen: the Nagssugtoqidian Orogen, West Greenland. Canadian Journal of Earth Sciences 37, 1121-1142.

Connelly, J.N., Thrane, K., Krawiec, A.W. \& Garde, A.A. 2006: Linking the Palaeproterozoic Nagssugtoqidian and Rinkian orogens through the Disko Bugt region of West Greenland. Journal of the Geological Society (London) 163, 319-335.

Conway Morris, S. \& Peel, J.S. 1990: Articulated halkieriids from the Lower Cambrian of North Greenland. Nature 345, 802-805.

Conway Morris, S. \& Peel, J.S. 1995: Articulated halkieriids from the Lower Cambrian of North Greenland and their role in early protostome evolution. Philosophical Transactions of the Royal Society of London B 347, 305-358.

Conway Morris, S. \& Peel, J.S. 2008: The earliest annelids: Lower Cambrian polychaetes from the Sirius Passet Lagerstätte, Peary Land, North Greenland. Acta Palaeontologica Polonica 53, 137-148.

Cowie, J.W. \& Adams, P.J. 1957: The geology of the CambroOrdovician rocks of central East Greenland. Part I. Stratigraphy and structure. Meddelelser om Grønland 153(1), 193 pp.

Crowley, J.L. 2002: Testing the model of late Archaean terrane accretion in southern West Greenland: a comparison of the timing of geological events across the Qarliit nunaat fault, Buksefjorden region. Precambrian Research 116, 57-79.

Dahl-Jensen, T., Jackson, H.R., Chian, D., Shimeid, J.W. \& Oakey, G. 2006: Crustal structure from the Lincoln Sea to the Lomonosov Ridge, Arctic Ocean. International Geological Congress Oslo 2006, Abstracts, Session UNC-06: National delineation projects in progress.

Dalhoff, F., Chalmers, J.A., Gregersen, U., Nøhr-Hansen, H., Rasmussen, J.A. \& Sheldon, E. 2003: Mapping and facies analysis of Paleocene-Mid-Eocene seismic sequences, offshore southern West Greenland. Marine and Petroleum Geology 20, 935-986.

Dalhoff, F., Larsen, L.M., Ineson, J.R., Stouge, S., Bojesen-Koefoed, J.A., Lassen, S., Kuipers, A., Rasmussen, J.A. \& Nøhr-Hansen, H. 2006: Continental crust in the Davis Strait: new evidence from seabed sampling. Geological Survey of Denmark and Greenland Bulletin 10, 33-36.

Dam, G. 1997: Sedimentology of the Umiivik-1 core, Svartenhuk Halvø, West Greenland. Danmarks og Grønlands Geologiske Undersøgelse Rapport 1997/136, 15 pp. + 1 enclosure.

Dam, G. 2002: Sedimentology of magmatically and structurally controlled outburst valleys along rifted volcanic margins: examples from the Nuussuaq Basin, West Greenland. Sedimentology 49, 505-632.

Dam, G. \& Christiansen, F.G. 1990: Organic geochemistry and source rock potential of the lacustrine shales of the Upper Triassic - Lower Jurassic Kap Stewart Formation, East Greenland. Marine and Petroleum Geology 7, 428-443.

Dam, G. \& Sønderholm, M. 1994: Lowstand slope channels of the Itilli succession (Maastrichtian - Lower Paleocene), Nuussuaq, West Greenland. Sedimentary Geology 94, 49-71.

Dam, G. \& Sønderholm, M. 1998: Sedimentological evolution of a fault-controlled Early Paleocene incised valley system, Nuussuaq Basin, West Greenland. In: Shanley, K.W. \& McCabe, P.J. (eds): Relative role of eustasy, climate and tectonism in continental rocks. Society of Economic Paleontologists and Mineralogists Special Publication 59, 109-121.

Dam, G. \& Surlyk, F. 1993: Cyclic sedimentation in a large waveand storm-dominated anoxic lake; Kap Stewart Formation (Rhaetian-Sinemurian), Jameson Land, East Greenland. In: Posamentier, H.W. et al. (eds): Sequence stratigraphy and facies associations. International Association of Sedimentologists Special Publication 18, 419-448.

Dam, G. \& Surlyk, F. 1998: Stratigraphy of the Neill Klinter Group; a Lower - lower Middle Jurassic tidal embayment succession, Jameson Land, East Greenland. Geology of Greenland Survey Bulletin 175, 80 pp.

Dam, G., Surlyk, F., Mathiesen, A. \& Christiansen, F.G. 1995: Exploration significance of lacustrine forced regressions of the Rhaetian-Sinemurian Kap Stewart Formation, Jameson Land, East Greenland. In: Steel, R.J. et al. (eds): Sequence stratigraphy on the Northwest European margin. Proceedings of the Norwegian Petroleum Society Conference, Stavanger, Norway, 1-3 February 1993. Norwegian Petroleum Society Special Publications 5, 511-527.

Dam, G., Larsen, M. \& Sønderholm, M. 1998: Sedimentary response to mantle plumes: implications from Paleocene onshore successions, West and East Greenland. Geology 26(3), 207-210. 
Dam, G., Nøhr-Hansen, H., Pedersen, G.K. \& Sønderholm, M. 2000: Sedimentary and structural evidence of a new early Campanian rift phase in the Nuussuaq Basin, West Greenland. Cretaceous Research 21, 127-154.

Dam, G., Pedersen, G.K., Sønderholm, M., Midtgaard, H.H., Larsen, L.M., Nøhr-Hansen, H. \& Pedersen, A.K. 2009: Lithostratigraphy of the Cretaceous-Paleocene Nuussuaq Group, Nuussuaq Basin, West Greenland. Geological Survey of Denmark and Greenland Bulletin 19.

Dansgaard, W. 1997: Ice cores and human history. Science 276, 1013 only.

Dawes, P.R. 1988: Etah meta-igneous complex and the Wullf structure: Proterozoic magmatism and deformation in Inglefield Land, North-West Greenland. Rapport Grønlands Geologiske Undersøgelse 139, $24 \mathrm{pp}$.

Dawes, P.R. 1990: The North Greenland continental margin. In: Grantz, A., Johnson, L. \& Sweeney, J.F. (eds): The Arctic Ocean region. The geology of North America L, 211-226. Boulder, Colorado: Geological Society of America.

Dawes, P.R. 1991: Geological map of Greenland, 1:500 000, Sheet 5, Thule. Copenhagen: Geological Survey of Greenland.

Dawes, P.R. 1997: The Proterozoic Thule Supergroup, Greenland and Canada: history, lithostratigraphy and development. Geology of Greenland Survey Bulletin 174, 150 pp.

Dawes, P.R. 2004: Explanatory notes to the Geological map of Greenland, 1:500 000, Humboldt Gletscher, Sheet 6. Geological Survey of Denmark and Greenland Map Series 1, 48 pp. + map.

Dawes, P.R. 2006: Explanatory notes to the Geological map of Greenland, 1: 500 000. Thule, Sheet 5. Geological Survey of Denmark and Greenland Map Series 2, 97 pp. + map.

Dawes, P.R. 2009a: Precambrian-Palaeozoic geology of Smith Sound, Canada and Greenland: key constraint to palaeogeographic reconstructions of northern Laurasia and the North Atlantic. Terra Nova 21, 1-13.

Dawes, P.R. 2009b: The bedrock geology under the Inland Ice: the next major challenge for Greenland mapping. Geological Survey of Denmark and Greenland Bulletin 17, 57-60.

Dawes, P.R. \& Garde, A.A. 2004: Geological map of Greenland, 1:500 000, Sheet 6, Humboldt Gletscher. Copenhagen: Geological Survey of Denmark and Greenland.

Dawes, P.R. \& Kerr, J.W. (eds) 1982: Nares Strait and the drift of Greenland: a conflict in plate tectonics. Meddelelser om Grønland Geoscience 8, 392 pp.

Dawes, P.R. \& Rex, D.C. 1986: Proterozoic basaltic magmatic periods in North-West Greenland: evidence from K/Ar ages. Rapport Grønlands Geologiske Undersøgelse 130, 24-31.

Dawes, P.R. \& Vidal, G. 1985: Proterozoic age of the Thule Group: new evidence from microfossils. Rapport Grønlands Geologiske Undersøgelse 125, 22-28.

Dawes, P.R., Frisch, T. \& Christie, R.L. 1982: The Proterozoic Thule Basin of Greenland and Ellesmere Island: importance to the Nares Strait debate. In: Dawes, P.R. \& Kerr, J.W. (eds): Nares Strait and the drift of Greenland: a conflict in plate tectonics. Meddelelser om Grønland Geoscience 8, 89-104.

de Freitas, T.A., Trettin, H.P., Dixon, O.A. \& Mallamo, M. 1999:
Silurian system of the Canadian Arctic Archipelago. Bulletin of Canadian Petroleum Geology 47, 136-193.

De Paor, D.G., Bradley, D.C., Eisenstadt, G. \& Phillips, S.M. 1989: The Arctic Eurekan orogen: a most unusual fold-and-thrust belt. Bulletin of the Geological Society of America 101, 952-967.

DePaolo, D.J. 1981: Neodymium isotopes in the Colorado Front Range and crust mantle evolution in the Proterozoic. Nature 291, 193-196.

Døssing, A., Dahl-Jensen, T., Thybo, H., Mejde, R. \& Nishimura, Y. 2008: East Greenland Ridge in the North Atlantic Ocean: an integrated geophysical study of a continental slither in a boundary transform fault setting. Journal of Geophysical Research 113(B10107), 23 pp. http://dx.doi.org/10.1029/2007JB005536

Drachev, S.S. 2000: Laptev Sea rifted continental margin: modern knowledge and unsolved questions. Polarforschung 68, 41-50.

Dymek, R.F. \& Owens, B.E. 2001: Chemical assembly of Archaean anorthosites from amphibolite- and granulite-facies terranes, SW Greenland. Contributions to Mineralogy and Petrology 141, 513-528.

Eldholm, O., Skogseid, J., Sundvor, E. \& Myhre, A.M. 1990: The Norwegian-Greenland Sea. In: Grantz, A., Johnson, L. \& Sweeney, J.F. (eds): The Arctic Ocean region. The geology of North America L, 351-364. Boulder, Colorado: Geological Society of America.

Elvevold, S., Thrane, K. \& Gilotti, J.A. 2003: Metamorphic history of high-pressure granulites in Payer Land, Greenland Caledonides. Journal of Metamorphic Geology 21, 49-63.

Emeleus, C.H. \& Upton, B.G.J. 1976: The Gardar period in southern Greenland. In: Escher, A. \& Watt, W.S. (eds): Geology of Greenland, 152-181. Copenhagen: Geological Survey of Greenland.

Engen, Ø., Faleide, J.I. \& Dyreng, T.K. 2008: Opening of the Fram Strait gateway: a review of plate tectonic constraints. Tectonophysics 450, 51-69.

Escher, J.C. 1985: Geological map of Greenland, 1:500 000, Sheet 4, Upernavik Isfjord. Copenhagen: Geological Survey of Greenland.

Escher, J.C. \& Pulvertaft, T.C.R. 1995: Geological map of Greenland, 1:2 500 000. Copenhagen: Geological Survey of Greenland.

Estrada, S., Höhndorf, A. \& Henjes-Kunst, F. 2001: Cretaceous/ Tertiary volcanism in North Greenland: the Kap Washington Group. Polarforschung 69, 17-23.

Evans, J., Cofaigh, C.O, Dowdeswell, J.A. \& Wadhams, P. 2009: Marine geophysical evidence for former expansion and flow of the Greenland ice sheet across the North-East Greenland continental shelf. Journal of Quaternary Science 24(3), 279-293.

Faleide, J.I., Tsikalas, F., Breivik, A.J., Mjelde, R., Ritzmann, O., Engen, Ø., Wilson, J. \& Eldholm, O. 2008: Structure and evolution of the continental margin off Norway and the Barents Sea. Episodes 31, 82-91.

Frederiksen, K.S. \& Craig, L.E. 1998: Field observations and preliminary sedimentary interpretation of the marine shallow-water platform and slope carbonates of the Upper Proterozoic Andrée Land Group, East Greenland. In: Higgins, A.K. \& Frederiksen, K.S. (eds): Caledonian geology of East Greenland $72^{\circ}-74^{\circ} \mathrm{N}$ : preliminary reports from the 1997 expedition. Danmarks og Grønlands Geologiske Undersøgelse Rapport 1998/28, 83-93.

Friderichsen, J.D., Higgins, A.K., Hurst, J.M., Pedersen, S.A.S., 
Soper, N.J. \& Surlyk, F. 1982: Lithostratigraphic framework of the Upper Proterozoic and Lower Palaeozoic deep water clastic deposits of North Greenland. Rapport Grønlands Geologiske Undersøgelse 107, 20 pp.

Friderichsen, J.D., Henriksen, N. \& Strachan, R.A. 1994: Basement-cover relationships and regional structure in the Grandjean Fjord - Bessel Fjord region $\left(75^{\circ}-76^{\circ} \mathrm{N}\right)$, North-East Greenland. In: Higgins, A.K. (ed.): Geology of North-East Greenland. Rapport Grønlands Geologiske Undersøgelse 162, 17-33.

Friend, C.R.L. \& Nutman, A.P. 1989: The geology and structural setting of the Proterozoic Ammassalik Intrusive Complex, East Greenland. In: Kalsbeek, F. (ed.): Geology of the Ammassalik region, South-East Greenland. Rapport Grønlands Geologiske Undersøgelse 146, 41-45.

Friend, C.R.L. \& Nutman, A.P. 1994: Two Archaean granulite-facies metamorphic events in the Nuuk-Maniitsoq region, southern West Greenland: correlation with the Saglek block, Labrador. Journal of the Geological Society (London) 151, 421-424.

Friend, C.R.L. \& Nutman, A.P. 2001: Blocks of 2940-2840 Ma crust with different metamorphic histories, Paamiut region, SouthWest Greenland: implications for the tectonic assembly of gneiss terranes. Precambrian Research 105, 143-164.

Friend, C.R.L. \& Nutman, A.P. 2005: New pieces to the Archaean terrane jigsaw puzzle in the Nuuk region, southern West Greenland: steps in transforming a simple insight into a complex regional tectonothermal model. Jounal of the Geological Society (London) 162, 147-162.

Friend, C.R.L., Brown, M., Perkins, W.T. \& Burwell, A.D.M. 1985: The geology of the Qôrqut granite complex north of Qôrqut, Godthåbsfjord, southern West Greenland. Bulletin Grønlands Geologiske Undersøgelse 151, 43 pp.

Friend, C.R.L., Nutman, A.P. \& McGregor, V.R. 1987: Late-Archaean tectonics in the Færingehavn - Tre Brødre area, south of Buksefjorden, southern West Greenland. Journal of the Geological Society (London) 144, 369-376.

Friend, C.R.L., Nutman, A.P. \& McGregor, V.R. 1988: Late Archaean terrane accretion in the Godthåb region, southern West Greenland. Nature 335, 535-538.

Friend, C.R.L., Nutman, A.P., Baadsgaard, H. \& Duke, M.J.M. 2009: The whole-rock Sm-Nd 'age' for the 2825 Ma Ikkattoq gneisses (Greenland) is $800 \mathrm{Ma}$ too young: insights into Archaean TTG petrogenesis. Chemical Geology 261, 62-76.

Funck, T., Jackson, H.R., Dehler, S. \& Reid, I.D. 2006: A refraction seismic transect from Greenland to Ellesmere Island, Canada: the crustal structure in southern Nares Strait. Polarforschung 74, 97-112.

Funck, T., Jackson, H.R., Louden, K.E. \& Klingelhöfer, F. 2007: Seismic study of the transform-rifted margin in Davis Strait between Baffin Island (Canada) and Greenland: What happens when a plume meets a transform. Journal of Geophysical Research 112(B04402), 22 pp. http://dx.doi.org/10.1029/2006JB004308

Funder, S. (co-ordinator) 1989: Quaternary geology of the ice-free areas and adjacent shelves of Greenland. In: Fulton, R.J. (ed.): Quaternary geology of Canada and Greenland. The geology of North America K-1, 741-792. Boulder, Colorado: Geological Society of America (also Geology of Canada 1, Geological Survey of Canada).

Funder, S. \& Hansen, L. 1996: The Greenland ice sheet - a model for its culmination and decay during and after the last glacial maximum. Bulletin of the Geological Society of Denmark 42, $137-152$.

Funder, S. \& Hjort, C. 1980: A reconnaissance of the Quaternary geology of eastern North Greenland. Rapport Grønlands Geologiske Undersøgelse 99, 99-105.

Funder, S., Hjort, C., Landvik, J.Y., Nam, S.-I., Reeh, N. \& Stein, R. 1998: History of a stable ice margin - East Greenland during the Middle and Upper Pleistocene. Quaternary Science Reviews 17, 77-123.

Garde, A.A. 1978: The lower Proterozoic Marmorilik Formation, east of Mârmorilik, West Greenland. Meddelelser om Grønland 200(3), $71 \mathrm{pp}$.

Garde, A.A. 1990: Thermal granulite-facies metamorphism with diffuse retrogression in Archaean orthogneisses, Fiskefjord, southern West Greenland. Journal of Metamorphic Geology 8, 663-682.

Garde, A.A. 1994: Precambrian geology between Qarajaq Isfjord and Jakobshavn Isfjord, West Greenland, 1:250 000. Copenhagen: Geological Survey of Greenland.

Garde, A.A. 1997: Accretion and evolution of an Archaean highgrade grey gneiss - amphibolite complex: the Fiskefjord area, southern West Greenland. Geology of Greenland Survey Bulletin 177, 115 pp.

Garde, A.A. 2007a: A mid-Archaean island arc complex in the eastern Akia terrane, Godthåbsfjord, southern West Greenland. Journal of the Geological Society (London) 164, 565-579.

Garde, A.A. 2007b: Geological map of Greenland, 1:500 000, Sheet 1, Sydgrønland (2nd edition). Copenhagen: Geological Survey of Denmark and Greenland.

Garde, A.A. \& Hollis, J.A. in press: A buried Palaeoproterozoic spreading ridge in the northern Nagssugtoqidian orogen, West Greenland. In: Kusky, T.M., Mingguo, Z. \& Xiao, W. (eds): The evolved continents: understanding the processes of continental growth. Geological Society Special Publication (London).

Garde, A.A. \& Schønwandt, H.K. 1995: Project SUPRASYD 1994 - Ketilidian supracrustal rocks in South-East Greenland and goldbearing shear zones in the Julianehåb batholith. Rapport Grønlands Geologiske Undersøgelse 165, 59-63.

Garde, A.A. \& Steenfelt, A. 1999: Precambrian geology of Nuussuaq and the area north-east of Disko Bugt, West Greenland. In: Kalsbeek, F. (ed.): Precambrian geology of the Disko Bugt region, West Greenland. Geology of Greenland Survey Bulletin 181, $6-40$.

Garde, A.A. \& Thomassen, B. 1990: Structural and economic aspects of the Proterozoic marble on Nûgssuaq, West Greenland. Open File Series Grønlands Geologiske Undersøgelse 90/6, 14 pp.

Garde A.A., Chadwick, B., Grocott, J., Hamilton, M.[A.], McCaffrey, K.[J.W.] \& Swager, C.P. 1998: An overview of the Palaeoproterozoic Ketilidian orogen, South Greenland. In: Wardle, R.J. \& Hall, J. (compilers): Eastern Canadian Shield Onshore-Offshore Transect (ESCOOT), Report of 1998 Transect Meeting. University of British Columbia, Lithoprobe Report 68, 50-66. 
Garde, A.A., Hamilton, M.A., Chadwick, B., Grocott, J. \& McCaffrey, K.J.W. 2002: The Ketilidian orogen of South Greenland: geochronology, tectonics, magmatism, and fore-arc accretion during Palaeoproterozoic oblique convergence. Canadian Journal of Earth Sciences 39, 756-793.

Gautier, D.L. et al. 2009: Assessment of undiscovered oil and gas in the Arctic. Science 324, 1175-1179.

Geyti, A. \& Thomassen, B. 1984: Molybdenum and precious metal mineralization at Flammefjeld, South-East Greenland. Economic Geology 79, 1921-1929.

Ghisler, M. 1976: The geology, mineralogy and geochemistry of the preorogenic Archaean stratiform chromite deposits at Fiskenaesset, West Greenland. Monograph Series on Mineral Deposits 14, 156 pp.

Gilotti, J.A. 1993: Discovery of a medium-temperature eclogite province in the Caledonides of North-East Greenland. Geology 21, 523-526.

Gilotti, J.A. \& McClelland, W.C. 2008: Geometry, kinematics, and timing of extensional faulting in the Greenland Caledonides - a synthesis. In: Higgins, A.K., Gilotti, J.A. \& Smith, M.P. (eds): The Greenland Caledonides: evolution of the northeast margin of Laurentia. Geological Society of America Memoir 202, 251-271.

Gilotti, J.A., Jones, K.A. \& Elvevold, S. 2008: Caledonian metamorphic patterns in Greenland. In: Higgins, A.K., Gilotti, J.A. \& Smith, M.P. (eds): The Greenland Caledonides: evolution of the northeast margin of Laurentia. Geological Society of America Memoir 202, 201-225.

Gregersen, U. 2008: The north-east Baffin Bay region, offshore Greenland - a new frontier petroleum exploration region. Geological Survey of Denmark and Greenland Bulletin 15, 65-68.

Gregersen, U. \& Bidstrup, T. 2008: Structures and hydrocarbon prospectivity in the northern Davis Strait area, offshore West Greenland. Petroleum Geoscience 14, 151-166.

Gregersen, U., Bidstrup, T., Bojesen-Koefoed, J.A., Christiansen, F.G., Dalhoff, F. \& Sønderholm, M. 2007: Petroleum systems and structures offshore central West Greenland: implications for hydrocarbon prospectivity. Geological Survey of Denmark and Greenland Bulletin 13, 25-28.

Grocott, J. \& Pulvertaft, T.C.R. 1990: The Early Proterozoic Rinkian belt of central West Greenland. In: Lewry, J.F. \& Stauffer, M.R. (eds): The Early Proterozoic Trans-Hudson Orogen of North America. Geological Association of Canada Special Paper 37, 443-463.

Gulson, B.L. \& Krogh, T.E. 1975: Evidence for multiple intrusion, possible resetting of $\mathrm{U}-\mathrm{Pb}$ ages, and new crystallization of zircons in the post-tectonic intrusions ('Rapakivi granites') and gneisses from South Greenland. Geochimica et Cosmochimica Acta 39, 65-82.

Håkansson, E. \& Pedersen, S.A.S. 1982: Late Paleozoic to Tertiary tectonic evolution of the continental margin in North Greenland. In: Embry, A.F. \& Balkwill, H.R. (eds): Arctic geology and geophysics. Canadian Society of Petroleum Geologists Memoir 8, 331-348.

Håkansson, E. \& Stemmerik, L. 1989: Wandel Sea basin - a synthesis of the late Paleozoic to Tertiary accumulation in North Greenland. Geology 17, 683-686.
Håkansson, E. \& Stemmerik, L. 1995: Wandel Sea Basin: basin analysis - a summary. Rapport Grønlands Geologiske Undersøgelse 165, 42-48.

Håkansson, E., Heinberg, C. \& Stemmerik, L. 1991: Mesozoic and Cenozoic history of the Wandel Sea Basin area, North Greenland. In: Peel, J.S. \& Sønderholm, M. (eds): Sedimentary basins of North Greenland. Bulletin Grønlands Geologiske Undersøgelse 160, 153-164.

Håkansson, E., Heinberg, C., Madsen, L., Mølgaard, S., Pedersen, S.A.S., Piasecki, S., Rasmussen, J.A., Stemmerik, L. \& ZinckJørgensen, K. 1994: Wandel Sea Basin: basin analysis - project summary. Completion report to the Ministry of Energy, 13 pp. Unpublished report, University of Copenhagen, Denmark (in archives of Geological Survey of Denmark and Greenland, GEUS Report File 11836).

Haller, J. 1971: Geology of the East Greenland Caledonides, 415 pp. London and New York: Interscience Publishers.

Hamann, N.E., Whittaker, R.C. \& Stemmerik, L. 2005: Geological development of the Northeast Greenland shelf. In: Doré, A.G. \& Vining, B.A. (eds): Petroleum geology: North-West Europe and global perspectives. Proceedings of the 6th Petroleum Geology Conference, 887-902. London: Geological Society.

Hambrey, M.J. \& Spencer, A.M. 1987: Late Precambrian glaciation of central East Greenland. Meddelelser om Grønland Geoscience 19, $50 \mathrm{pp}$.

Hammer, C.U. 1997: Isboringer i central Grønland. GRIP og NORTH-GRIP. Varv 1997(2), 41-59. København: Tidsskriftet Varv.

Hanmer, S., Hamilton, M.A. \& Crowley, J.L. 2002: Geochronological constraints on Paleoarchean thrust-nappe and Neoarchean accretionary tectonics in southern West Greenland. Tectonophysics 350, 255-271.

Hansen, B.T., Steiger, R.H. \& Higgins, A.K. 1980: Isotopic evidence for a Precambrian metamorphic event within the Charcot Land window, East Greenland Caledonian fold belt. Bulletin of the Geological Society of Denmark 29, 151-160.

Harland, W.B. 1969: Contribution of Spitsbergen to understanding of tectonic evolution of North Atlantic region. In: Kay, M. (ed.): North Atlantic geology and continental drift. American Association of Petroleum Geologists Memoir 12, 817-851.

Harpøth, O., Pedersen, J.L., Schønwandt, H.K. \& Thomassen, B. 1986: The mineral occurrences of central East Greenland. Meddelelser om Grønland Geoscience 17, 138 pp.

Harrison, J.C. 2006: In search of the Wegener Fault: re-evaluation of strike-slip displacements along and bordering Nares Strait. Polarforschung 74, 129-160.

Harrison, J.C. et al. 2008: Geological map of the Arctic. Geological Survey of Canada, Open File 5816, scale 1:5000 000.

Hartz, E. \& Andresen, A. 1995: Caledonian sole thrust of central East Greenland: a crustal-scale Devonian extensional detachment? Geology 23, 637-640.

Henderson, G. 1969: The Precambrian rocks of the EgedesmindeChristianshåb area, West Greenland. Rapport Grønlands Geologiske Undersøgelse 23, 37 pp.

Henderson, G. \& Pulvertaft, T.C.R. 1987: Geological map of Green- 
land, 1:100 000, Mârmorilik 71 V.2 Syd, Nûgâtsiaq 71 V.2 Nord, Pangnertôq 72 V.2 Syd. Descriptive text, 72 pp., 8 plates. Copenhagen: Grønlands Geologiske Undersøgelse [Geological Survey of Greenland].

Henderson, J.R. 1983: Structure and metamorphism of the Aphebian Penrhyn Group and its Archean basement complex in the Lyon Inlet area, Melville Peninsula, District of Franklin. Bulletin of the Geological Survey of Canada 324, 50 pp.

Henderson, J.R. \& Tippet, C.R. 1980: Foxe fold belt in eastern Baffin Island, District of Franklin. Geological Survey of Canada Paper 80-1A, 147-152.

Henriksen, N. 1985: The Caledonides of central East Greenland $70^{\circ}-76^{\circ}$ N. In: Gee, D.G. \& Sturt, B.A. (eds): The Caledonide orogen - Scandinavia and related areas, 1095-1113. London: Wiley \& Sons Ltd.

Henriksen, N. 1986: Geological map of Greenland, 1:500 000, Scoresby Sund, Sheet 12. Descriptive text, 27 pp. Copenhagen: Geological Survey of Greenland.

Henriksen, N. 1992: Geological map of Greenland, 1:500 000, Nyeboe Land, Sheet 7, Peary Land, Sheet 8. Descriptive text, 40 pp., 2 maps. Copenhagen: Geological Survey of Greenland.

Henriksen, N. 2003: Caledonian Orogen, East Greenland $70^{\circ}-82^{\circ} \mathrm{N}$. Geological map 1:1 000 000. Copenhagen: Geological Survey of Denmark and Greenland (also Plate 1 in Henriksen, N. \& Higgins, A.K. 2008: Caledonian Orogen, East Greenland $70^{\circ}-82^{\circ} \mathrm{N}$. Geological map 1:1 000 000. In: Higgins, A.K., Gilotti, J.A. \& Smith, M.P. (eds): The Greenland Caledonides: evolution of the northeast margin of Laurentia. Geological Society of America Memoir 202, 345-368).

Henriksen, N. \& Higgins, A.K. 1969: Preliminary results of mapping in the crystalline complex around Nordvestfjord, Scoresby Sund, East Greenland. Rapport Grønlands Geologiske Undersøgelse 21, 5-20.

Henriksen, N. \& Higgins, A.K. 1976: East Greenland Caledonian fold belt. In: Escher, A. \& Watt, W.S. (eds): Geology of Greenland, 182-246, Copenhagen: Geological Survey of Greenland.

Henriksen, N. \& Higgins, A.K. 2000: Early Palaeozoic basin development of North Greenland - part of the Franklinian Basin. Polarforschung 68, 131-140.

Henriksen, N., Higgins, A.K., Kalsbeek, F. \& Pulvertaft, T.C.R. 2000: Greenland from Archean to Quarternary. Descriptive text to the Geological map of Greenland, 1:2 500 000. Geology of Greenland Survey Bulletin 185, 93 pp. + 1 map.

Higgins, A.K. 1968: The Târtoq Group on Nuna qaqertoq and in the Iterdlak area, South-West Greenland. Rapport Grønlands Geologiske Undersøgelse 17, 44 pp.

Higgins, A.K. 1970: The stratigraphy and structure of the Ketilidian rocks of Midternæs, South-West Greenland. Bulletin Grønlands Geologiske Undersøgelse 87, 96 pp. (also Meddelelser om Grønland 189(2)).

Higgins, A.K. 1974: The Krummedal supracrustal sequence around inner Nordvestfjord, Scoresby Sund, East Greenland. Rapport Grønlands Geologiske Undersøgelse 67, 34 pp.

Higgins, A.K. 1988: The Krummedal supracrustal sequence in East Greenland. In: Winchester, J.A. (ed.): Later Proterozoic stratig- raphy of the northern Atlantic regions, 86-96. Glasgow: Blackie \& Son; New York: Chapman \& Hall.

Higgins, A.K. \& Leslie, A.G. 2000: Restoring thrusting in the East Greenland Caledonides. Geology 28, 1019-1022.

Higgins, A.K. \& Leslie, A.G. 2008: Architecture and evolution of the East Greenland Caledonides - an introduction. In: Higgins, A.K., Gilotti, J.A. \& Smith, M.P. (eds): The Greenland Caledonides: evolution of the northeast margin of Laurentia. Geological Society of America Memoir 202, 29-53.

Higgins, A.K., Friderichsen, J.D. \& Thyrsted, T. 1981: Precambrian metamorphic complexes in the East Greenland Caledonides $\left(72^{\circ}-74^{\circ} \mathrm{N}\right)$ - their relationships to the Eleonore Bay Group, and Caledonian orogenesis. Rapport Grønlands Geologiske Undersøgelse 104, 5-46.

Higgins, A.K., Ineson, J.R., Peel, J.S., Surlyk, F. \& Sønderholm, M. 1991: Lower Palaeozoic Franklinian Basin of North Greenland. In: Peel, J.S. \& Sønderholm, M. (eds): Sedimentary basins of North Greenland. Bulletin Grønlands Geologiske Undersøgelse 160, 71-139.

Higgins, A.K., Soper, N.J. \& Leslie, A.G. 2000: The Ellesmerian and Caledonian orogenic belts of Greenland: Polarforschung 68, 141-151.

Higgins, A.K., Leslie, A.G. \& Smith, M.P. 2001a: NeoproterozoicLower Palaeozoic stratigraphical relationships in the marginal thin-skinned thrust belt of the East Greenland Caledonides: comparisons with the foreland of Scotland: Geological Magazine 138, 143-160.

Higgins, A.K., Smith, M.P., Soper, N.J., Leslie, A.G., Rasmussen, J.A. \& Sønderholm, M. 2001b: The Neoproterozoic Hekla Sund Basin, eastern North Greenland: a pre-Iapetan extensional sequence thrust across its rift shoulders during the Caledonian orogeny. Journal of the Geological Society (London) 158, 487-499.

Higgins, A.K. et al. 2004a: The foreland-propagating thrust architecture of the East Greenland Caledonides $72^{\circ}-75^{\circ} \mathrm{N}$. Journal of the Geological Society (London) 161, 1009-1026.

Higgins, A.K., Soper, N.J., Smith, M.P. \& Rasmussen, J.A. 2004b: The Caledonian parautochthonous fold and thrust belt of Kronprins Christian Land, eastern North Greenland. In: Higgins, A.K. \& Kalsbeek, F. (eds): East Greenland Caledonides: stratigraphy, structure and geochronology. Geological Survey of Denmark and Greenland Bulletin 6, 41-56.

Higgins, A.K., Gilotti, J.A. \& Smith, M.P. (eds) 2008: The Greenland Caledonides: evolution of the northeast margin of Laurentia. Geological Society of America Memoir 202, 368 pp.

Hollis J.A., Keiding, M., Stensgaard, B.M., van Gool, J.A.M. \& Garde, A.A. 2006: Evolution of Neoarchaean supracrustal belts at the northern margin of the North Atlantic Craton, West Greenland. In: Garde, A.A. \& Kalsbeek, F. (eds): Precambrian crustal evolution and Cretaceous-Palaeogene faulting in West Greenland. Geological Survey of Denmark and Greenland Bulletin 11, 9-31.

Hull, J.M., Friderichsen, J.D., Gilotti, J.A., Henriksen, N., Higgins, A.K. \& Kalsbeek, F. 1994: Gneiss complex of the Skærfjorden region $\left(76^{\circ}-78^{\circ} \mathrm{N}\right)$, North-East Greenland. In: Higgins, A.K. (ed.): Geology of North-East Greenland. Rapport Grønlands Geologiske Undersøgelse 162, 35-51. 
Hurst, J.M. 1980: Silurian stratigraphy and facies distribution in Washington Land and western Hall Land, North Greenland. Bulletin Grønlands Geologiske Undersøgelse 138, 95 pp.

Hurst, J.M. 1984: Upper Ordovician and Silurian carbonate shelf stratigraphy, facies and evolution, eastern North Greenland. Bulletin Grønlands Geologiske Undersøgelse 148, 73 pp.

Hurst, J.M. \& Surlyk, F. 1982: Stratigraphy of the Silurian turbidite sequence of North Greenland. Bulletin Grønlands Geologiske Undersøgelse 145, $121 \mathrm{pp}$.

Hutchison, M.T. \& Heaman, L.M. 2008: Chemical and physical characteristics of diamond crystals from Garnet Lake, Sarfartoq, West Greenland: an association with carbonatitic magmatism. Canadian Mineralogist 46, 1063-1078.

Ineson, J.R. \& Peel, J.S. 1997: Cambrian shelf stratigraphy of North Greenland. Geology of Greenland Survey Bulletin 173, 120 pp.

Ineson, J.R. \& Surlyk, F. (eds) 2003: The Jurassic of Denmark and Greenland. Geological Survey of Denmark and Greenland Bulletin 1, $948 \mathrm{pp}$.

Ineson, J.R., Surlyk, F., Higgins, A.K. \& Peel, J.S. 1994: Slope apron and deep shelf sediments of the Brønlund Fjord and Tavsens Iskappe Groups (Lower Cambrian - Lower Ordovician), North Greenland: stratigraphy, facies and depositional setting. In: Peel, J.S. (ed.): Palaeontology, stratigraphy and environmental setting of Middle Cambrian outer shelf deposits, North Greenland. Bulletin Grønlands Geologiske Undersøgelse 169, 7-24.

Irvine, T.N., Andersen, J.C.Ø. \& Brooks, C.K. 1998: Included blocks (and blocks within blocks) in the Skaergaard intrusion: geologic relations and the origins of rhythmic modally graded layers. Geological Society of America Bulletin 110(11), 1398-1447.

Jensen, S.M. 1998: Carbonate-hosted Zn-Pb-Ag mineralisation in Washington Land, western North Greenland. Geology of Greenland Survey Bulletin 180, 67-72.

Jensen, S.M., Secher, K., Rasmussen, T.M. \& Schjøth, F. 2004: Diamond exploration data from West Greenland: 2004 update and revision. Danmarks og Grønlands Geologiske Undersøgelse Rapport 2004/117, 90 pp. + 1 DVD.

Jepsen, H.F. 1971: The Precambrian, Eocambrian and early Palaeozoic stratigraphy of the Jørgen Brønlund Fjord area, Peary Land, North Greenland. Meddelelser om Grønland 192(2), 1-42.

Jepsen, H.F. 2000: Geological map of Greenland, 1:500 000, Sheet 9, Lambert Land. Copenhagen: Geological Survey of Denmark and Greenland.

Jepsen, H.F. \& Kalsbeek, F. 1998: Granites in the Caledonian fold belt of East Greenland. In: Higgins, A.K. \& Frederiksen, K.S. (eds): Caledonian geology of East Greenland $72^{\circ}-74^{\circ} \mathrm{N}$ : preliminary reports from the 1997 expedition. Danmarks og Grønlands Geologiske Undersøgelse Rapport 1998/28, 73-82.

Johansson, Å., Larionov, A.N., Tebenkov, A.M., Gee, D.G., Whitehouse, M.J. \& Vestin, J. 2000: Grenvillian magmatism of western and central Nordaustlandet, northeastern Svalbard. Transactions of the Royal Society of Edinburgh, Earth Sciences 90, 221-254.

Jokat, W., Schroeder, M., Leinweber, V. \& Schenke, H.W. 2005: Insights into the evolution of the Yermak Plateau and the adjacent Lena Trough. Geophysical Research Abstracts 7, 05149 only.
Jokat, W., Geissler, W. \& Voss, M. 2008: Basement structure of the north-western Yermak Plateau. Geophysical Research Letters 35(L05309), 6 pp. http://dx.doi.org/10.1029/2007GL032892.

Kalsbeek, F. 1976: Metamorphism of Archaean rocks of West Greenland. In: Windley, B.F. (ed.): The early history of the Earth, 225-235. London: Wiley.

Kalsbeek, F. 1981: The northward extent of the Archaean basement of Greenland - a review of Rb-Sr whole-rock ages. Precambrian Research 14, 203-219.

Kalsbeek, F. (ed.) 1989: Geology of the Ammassalik region, SouthEast Greenland. Rapport Grønlands Geologiske Undersøgelse 146, 106 pp.

Kalsbeek, F. 1992: Large-scale albitisation of siltstones on Qeqertakavsak island, northeast Disko Bugt, West Greenland. Chemical Geology 95, 213-233.

Kalsbeek, F. 1994: Archaean and early Proterozoic basement provinces in Greenland. Rapport Grønlands Geologiske Undersøgelse 160, 37-40.

Kalsbeek, F. \& Frei, R. 2006: The Mesoproterozoic Midsommersø dolerites and associated high-silica intrusions, North Greenland: crustal melting, contamination and hydrothermal alteration. Contributions to Mineralogy and Petrology 152, 89-110.

Kalsbeek, F. \& Jepsen, H.F. 1983: The Midsommersø Dolerites and associated intrusions in the Proterozoic platform of eastern North Greenland - a study of the interaction between intrusive basic magma and sialic crust. Journal of Petrology 24, 605-634.

Kalsbeek, F. \& Jepsen, H.F. 1984: The late Proterozoic Zig-Zag Dal Basalt Formation of eastern North Greenland. Journal of Petrology 25, 644-664.

Kalsbeek, F. \& Manatschal, G. 1999: Geochemistry and tectonic significance of peridotitic and meta-komatiitic rocks from the Ussuit area, Nagssugtoqidian orogen, West Greenland. Precambrian Research 94, 101-120.

Kalsbeek, F. \& Nutman, A.P. 1996: Anatomy of the Early Proterozoic Nagssugtoqidian orogen, West Greenland, explored by reconnaissance SHRIMP U-Pb zircon dating. Geology 24, 515-518.

Kalsbeek, F. \& Skjernaa, L. 1999: The Archaean Atâ intrusive complex (Atâ tonalite), north-east Disko Bugt, West Greenland. In: Kalsbeek, F. (ed.): Precambrian geology of the Disko Bugt region, West Greenland. Geology of Greenland Survey Bulletin 181, 103-112.

Kalsbeek, F. \& Taylor, P.N. 1985: Isotopic and chemical variation in granites across a Proterozoic continental margin - the Ketilidian mobile belt of South Greenland. Earth and Planetary Science Letters 73, 65-80.

Kalsbeek, F., Pidgeon, R.T. \& Taylor, P.N. 1987: Nagssugtoqidian mobile belt of West Greenland: cryptic 1850 Ma suture between two Archaean continents - chemical and isotopic evidence. Earth and Planetary Science Letters 85, 365-385.

Kalsbeek, F., Larsen, L.M. \& Bondam, J. 1990: Geological map of Greenland, 1:500 000, Sydgrønland, Sheet 1. Descriptive text, 36 pp. Copenhagen: Geological Survey of Greenland.

Kalsbeek, F., Austrheim, H., Bridgwater, D., Hansen, B.T., Pedersen, S. \& Taylor, P.N. 1993a: Geochronology of Archaean and Proterozoic events in the Ammassalik area, South-East Greenland, and 
comparisons with the Lewisian of Scotland and the Nagssugtoqidian of West Greenland. Precambrian Research 62, 239-270.

Kalsbeek, F., Nutman, A.P. \& Taylor, P.N. 1993b: Palaeoproterozoic basement province in the Caledonian fold belt of North-East Greenland. Precambrian Research 63, 163-178.

Kalsbeek, F., Pulvertaft, T.C.R. \& Nutman, A.P. 1998a: Geochemistry, age and origin of metagreywackes from the Palaeoproterozoic Karrat Group, Rinkian belt, West Greenland. Precambrian Research 91, 383-399.

Kalsbeek, F., Nutman, A.P. \& Jepsen, H.F. 1998b: Granites in the Caledonian fold belt, East Greenland. In: Frederiksen, K.S. \& Thrane, K. (eds): Symposium on Caledonian geology in East Greenland. Danmarks og Grønlands Geologiske Undersøgelse Rapport 1998/46, 43-44.

Kalsbeek, F., Nutman, A.P., Escher, J.C., Friderichsen, J.D., Hull, J.M., Jones, K.A. \& Pedersen, S.A.S. 1999: Geochronology of granitic and supracrustal rocks from the northern part of the East Greenland Caledonides: ion microprobe U-Pb zircon ages. Geology of Greenland Survey Bulletin 184, 31-48.

Kalsbeek, F., Thrane, K., Nutman, A.P. \& Jepsen, H.F. 2000: Late Mesoproterozoic to early Neoproterozoic history of the East Greenland Caledonides: evidence for Grenvillian orogenesis? Journal of the Geological Society (London) 157, 1215-1225.

Kalsbeek, F., Thrane, K., Higgins, A.K., Jepsen, H.F., Leslie, A.G., Nutman, A.P. \& Frei, R. 2008a: Polyorogenic history of the East Greenland Caledonides. In: Higgins, A.K., Gilotti, J.A. \& Smith, M.P. (eds): The Greenland Caledonides: evolution of the northeast margin of Laurentia. Geological Society of America Memoir 202, 55-72.

Kalsbeek, F., Higgins, A.K., Jepsen, H.F., Frei, R. \& Nutman, A.P. 2008b: Granites and granites in the East Greenland Caledonides. In: Higgins, A.K., Gilotti, J.A. \& Smith, M.P. (eds): The Greenland Caledonides: evolution of the northeast margin of Laurentia. Geological Society of America Memoir 202, 227-249.

Katz, H.R. 1952: Ein Querschnitt durch die Nunatakzone Ostgrönlands. Meddelelser om Grønland 144(8), 65 pp.

Keen, C.E. \& Barrett, D.L. 1972: Seismic refraction studies in Baffin Bay: an example of a developing ocean basin. Geophysical Journal of the Royal Astronomical Society 30, 253-271.

Kirkland, C.L., Pease, V., Whitehouse, M.J. \& Ineson, J.R. 2009: Provenance record from Mesoproterozoic-Cambrian sediments of Peary Land, North Greenland: implications for the ice-covered Greenland shield and Laurentian palaeogeography. Precambrian Research 170, 43-60.

Klausen, M.B. \& Larsen, H.C. 2002: East Greenland coast-parallel dike swarm and its role in continental breakup. In: Menzies, M.A. et al. (eds): Volcanic rifted margins. Geological Society of America Special Paper 362, 133-158.

KMS 1994: [Topographic map of] Kalaallit Nunaat, Grønland, 1:2 500 000. København: Kort \& Matrikelstyrelsen.

Knudsen, C. 1991: Petrology, geochemistry and economic geology of the Qaqarssuk carbonatite complex, southern West Greenland. Monograph Series on Mineral Deposits 29, 110 pp.

Kolb, J. \& Stensgaard, B.M. 2009: IOCG. Iron oxide copper-gold mineralising systems in Greenland. Geology and Ore 13, 12 pp.
Kovacs, L.C. 1982: Motion along Nares Strait recorded in the Lincoln Sea; aeromagnetic evidence. In: Dawes, P.R. \& Kerr, J.W. (eds): Nares Strait and the drift of Greenland: a conflict in plate tectonics. Meddelelser om Grønland Geoscience 8, 275-290.

Kragh, K., Jensen, S.M. \& Fougt, H. 1997: Ore geological studies of the Citronen Fjord zinc deposit, North Greenland: project 'Resources of the sedimentary basins of North and East Greenland'. Geology of Greenland Survey Bulletin 176, 44-49.

Kristoffersen, Y. 1990: Eurasia Basin. In: Grantz, A., Johnson, L. \& Sweeney, J.F. (eds): The Arctic Ocean region. The geology of North America L, 365-378. Boulder, Colorado: Geological Society of America.

Larsen, H.C. 1978: Offshore continuation of East Greenland dyke swarm and North Atlantic Ocean formation. Nature 274, 220-223.

Larsen, H.C. 1984: Geology of the East Greenland shelf. In: Spencer, A.M. (ed.): Petroleum geology of the North European margin, 329-339. London: Graham \& Trotman.

Larsen, H.C. 1985: Petroleum geological assessment of the East Greenland shelf (Project NAD - East Greenland). NAD final report no. 8, 78 pp., 18 encl. Unpublished report, Geological Survey of Greenland, Copenhagen (in archives of Geological Survey of Denmark and Greenland, GEUS Report File 16976).

Larsen, H.C. 1988: A multiple and propagating rift model for the NE Atlantic. In: Morton, A.C. \& Parson, L.M. (eds): Early Tertiary volcanism and the opening of the NE Atlantic. Geological Society Special Publication (London) 39, 157-158.

Larsen, H.C. 1990: The East Greenland shelf. In: Grantz, A., Johnson, L. \& Sweeney, J.F. (eds): The Arctic Ocean region. The geology of North America L, 185-210. Boulder, Colorado: Geological Society of America.

Larsen, H.C. \& Jakobsdóttir, S. 1988: Distribution, crustal properties and significance of seawards-dipping sub-basement reflectors off E Greenland. In: Morton, A.C. \& Parson, L.M. (eds): Early Tertiary volcanism and the opening of the NE Atlantic. Geological Society Special Publication (London) 39, 95-114.

Larsen, H.C. \& Pulvertaft, T.C.R. 1990: Regional marine seismic reconnaissance. Rapport Grønlands Geologiske Undersøgelse 148, 32-34.

Larsen, H.C. \& Saunders, A.D. 1998: Tectonism and volcanism at the southeast Greenland rifted margin: a record of plume impact and later continental rupture. In: Saunders, A.D. et al. (eds): Proceedings of the Ocean Drilling Program, scientific results 152 503-523. Texas: College Station.

Larsen, H.C., Saunders, A., Larsen, L.M., Lykke-Andersen, H., ODP Leg 152 shipboard party, Marcussen, C. \& Clausen, L. 1994a: ODP activities on the South-East Greenland margin: Leg 152 drilling and continued site surveying. Rapport Grønlands Geologiske Undersøgelse 160, 73-79.

Larsen, H.C. et al. 1994b: Initial report, ODP Leg 152, 977 pp. Texas College Station.

Larsen, H.C., Duncan, R.S., Allan, J.F. \& ODP Leg 163 shipboard party 1996: ODP Leg 163, South-East Greenland volcanic rifted margin. Bulletin Grønlands Geologiske Undersøgelse 172, 103-112.

Larsen, H.C., Dahl-Jensen, T. \& Hopper, J.R. 1998: Crustal struc- 
ture along the Leg 152 drilling transect. In: Saunders, A.D. et al. (eds): Proceedings of the Ocean Drilling Program, scientific results 152, 463-475. Texas: College Station.

Larsen, J.G. 1977: Petrology of the late lavas of the Eriksfjord Formation, Gardar province, South Greenland. Bulletin Grønlands Geologiske Undersøgelse 125, 31 pp.

Larsen, J.G. \& Pulvertaft, T.C.R. 2000: The structure of the Cretaceous-Palaeogene sedimentary-volcanic area of Svartenhuk Halvø, central West Greenland. Geology of Greenland Survey Bulletin 188, 40 pp.

Larsen, L.M. \& Pedersen, A.K. 1982: A minor carbonatite occurrence in southern West Greenland: the Tupertalik intrusion. Rapport Grønlands Geologiske Undersøgelse 110, 38-43.

Larsen, L.M. \& Pedersen, A.K. 2009: Petrology of the Paleocene picrites and flood basalts on Disko and Nuussuaq, West Greenland. Journal of Petrology 50, 1667-1711.

Larsen, L.M. \& Rex, D.C. 1992: A review of the 2500 Ma span of alkaline-ultramafic, potassic and carbonatitic magmatism in West Greenland. Lithos 28, 367-402.

Larsen, L.M., Watt, W.S. \& Watt, M. 1989: Geology and petrology of the Lower Tertiary plateau basalts of the Scoresby Sund region, East Greenland. Bulletin Grønlands Geologiske Undersøgelse 157, 164 pp.

Larsen, L.M., Waagstein, R., Pedersen, A.K. \& Storey M. 1999: Trans-Atlantic correlation of the Palaeogene volcanic successions in the Faeroe Islands and East Greenland. Journal of the Geological Society (London) 156, 1081-1095.

Larsen, L.M., Heaman, L.M., Creaser, R.A., Duncan, R.A., Frei, R. \& Hutchison, M. 2009: Tectonomagmatic events during stretching and basin formation in the Labrador Sea and Davis Strait: evidence from age and composition of Mesozoic to Palaeogene dyke swarms in West Greenland. Journal of the Geological Society (London) 166, 999-1012.

Larsen, M., Hamberg, L., Olaussen, S., Nørgaard-Pedersen, N. \& Stemmerik, L. 1999: Basin evolution in southern East Greenland: an outcrop analog for Cretaceous-Paleogene basins on the North Atlantic volcanic margins. American Association of Petroleum Geologists Bulletin 83(8), 1236-1261.

Larsen. M., Bjerager, M., Nedkvitne, T., Olaussen, S. \& Preuss, T. 2001: Pre-basaltic (Aptien-Paleocene) of the Kangerlussuaq Basin, southern East Greenland. Geology of Greenland Survey Bulletin 189, 99-106.

Larsen. M., Heilmann-Clausen, C., Piasecki, S. \& Stemmerik, L. 2005: At the edge of a new ocean: post-volcanic evolution of the Palaeogene Kap Dalton Group, East Greenland. In: Doré, A.G. \& Vining, B.A. (eds): Petroleum geology: North-West Europe and global perspectives - Proceedings of the 6th Petroleum Conference, 923-932. London: Geological Society.

Larsen, M., Knudsen, C., Frei, D., Frei, M., Rasmussen, T. \& Whitham, A.G. 2006: East Greenland and Faroe-Shetland sediment provenance and Palaeogene sand dispersal systems. Geological Survey of Denmark and Greenland Bulletin 10, 29-32.

Larsen, O. \& Graff-Petersen, P. 1980: Sr-isotopic studies and mineral composition of the Hagen Bræ Member in the Proterozoic clastic sediments at Hagen Bræ, eastern North Greenland. Rapport
Grønlands Geologiske Undersøgelse 99, 111-118.

Larsen, P.-H. \& Bengaard, H.-J. 1991: Devonian basin initiation in East Greenland: a result of sinistral wrench faulting and Caledonian extensional collapse. Journal of the Geological Society (London) 148, 355-368.

Larsen, P.-H. \& Escher, J.C. 1985: The Silurian turbidite sequence of the Peary Land Group between Newman Bugt and Victoria Fjord, western North Greenland. Rapport Grønlands Geologiske Undersøgelse 126, 47-67.

Larsen, P.-H., Olsen, H. \& Clack, J.A. 2008: The Devonian basin in East Greenland - review of basin evolution and vertebrate assemblages. In: Higgins, A.K., Gilotti, J.A. \& Smith, M.P. (eds): The Greenland Caledonides: evolution of the northeast margin of Laurentia. Geological Society of America Memoir 202, 273-292.

Leslie, A.G. \& Higgins, A.K. 2008: Foreland-propagating Caledonian thrust systems in East Greenland. In: Higgins, A.K., Gilotti, J.A. \& Smith, M.P. (eds): The Greenland Caledonides: evolution of the northeast margin of Laurentia. Geological Society of America Memoir 202, 169-199.

Leslie, A.G. \& Nutman, A.P. 2003: Evidence for Neoproterozoic orogenesis and early high temperature Scandian deformation events in the southern East Greenland Caledonides. Geological Magazine 140, 309-333.

Leslie, A.G., Smith, M. \& Soper, N.J. 2008: Laurentian margin evolution and the Caledonian orogeny - a template for Scotland and East Greenland. In: Higgins, A.K., Gilotti, J.A. \& Smith, M.P. (eds): The Greenland Caledonides: evolution of the northeast margin of Laurentia. Geological Society of America Memoir 202, 307-343.

Letréguilly, A., Reeh, N. \& Huybrechts, P. 1991: The Greenland ice sheet through the last glacial-interglacial cycle. Global and Planetary Change 94, 385-394.

Lundin, E. \& Doré, A.G. 2002: Mid-Cenozoic post-breakup deformation in the 'passive' margins bordering the Norwegian-Greenland Sea. Marine and Petroleum Geology 19, 79-93.

Lyck, J.M. \& Stemmerik, L. 2000: Palynology and depositional history of the Paleocene? Thyra Ø Formation, Wandel Sea Basin, eastern North Greenland. In: Stemmerik, L. (ed.): Palynology and deposition in the Wandel Sea Basin, eastern North Greenland. Geology of Greenland Survey Bulletin 187, 21-49.

McBirney, A.R. 1996a: The Skaergaard intrusion. In: Cawthorn, R.G. (ed.): Layered intrusions. Developments in Petrology 15, 147-189. Amsterdam: Elsevier.

McBirney, A.R. 1996b: Geological map of the Skaergaard intrusion (revised), 1:20 000. In: Cawthorn, R.G. (ed.): Layered intrusions. Developments in Petrology 15. Amsterdam: Elsevier.

McCaffrey, K.J.W., Grocott, J., Garde, A.A. \& Hamilton, M.A. 2004: Attachment formation during partitioning of oblique convergence in the Ketilidian orogen, South Greenland. Geological Society Special Publication (London) 227, 231-248.

McGregor, V.R. 1973: The early Precambrian gneisses of the Godthåb district, West Greenland. Philosophical Transactions of the Royal Society of London A273, 343-358.

McGregor, V.R. \& Friend, C.R.L. 1997: Field recognition of rocks totally retrogressed from granulite facies: an example from Archaean 
rocks in the Paamiut region, South-West Greenland. Precambrian Research 86, 59-70.

McGregor, V.R. \& Mason, B. 1977: Petrogenesis and geochemistry of metabasaltic and metasedimentary enclaves in the Amîtsoq gneisses, West Greenland. American Mineralogist 62, 887-904.

McMillan, N.J. 1982: Nares Strait and the petroleum explorer. In: Dawes, P.R. \& Kerr, J.W. (eds): Nares Strait and the drift of Greenland: a conflict in plate tectonics. Meddelelser om Grønland Geoscience 8, 355-361.

Marshall, B. \& Schønwandt, H.K. 1999: An Archaean sill complex and associated supracrustal rocks, Arveprinsen Ejland, north-east Disko Bugt, West Greenland. In: Kalsbeek, F. (ed.): Precambrian geology of the Disko Bugt region, West Greenland. Geology of Greenland Survey Bulletin 181, 87-102.

Marshall, J.E.A., Astin, T.R. \& Clack, J.A. 1999: East Greenland tetrapods are Devonian in age. Geology 27(7), 637-640.

Mathiesen, A., Christiansen, F.G., Bidstrup, T., Marcussen, C., Dam, G., Piasecki, S. \& Stemmerik, L. 1995: Modelling of hydrocarbon generation in the Jameson Land basin, East Greenland. First Break 13, 330-341.

Mayborn, K.R. \& Lescher, C.E. 2006: Origin and evolution of the Kangâmiut mafic dyke swarm, West Greenland. In: Garde, A.A. \& Kalsbeek, F. (eds): Precambrian crustal evolution and Cretaceous-Palaeogene faulting in West Greenland. Geological Survey of Denmark and Greenland Bulletin 11, 61-86.

Mazur, S., Piazolo, S. \& Alsop, G.I. 2006: Structural analysis of the northern Nagssugtoqidian orogen, West Greenland: an example of complex tectonic patterns in reworked high-grade metamorphic terrains. In: Garde, A.A. \& Kalsbeek, F. (eds): Precambrian crustal evolution and Cretaceous-Palaeogene faulting in West Greenland. Geological Survey of Denmark and Greenland Bulletin 11, 163-178.

MINEX 2002: Greenland is ready to join the new diamond rush in the Arctic. MINEX 22, 1-2. Copenhagen: Geological Survey of Denmark and Greenland, and Nuuk: Bureau of Minerals and Petroleum.

MINEX 2007a: Hudson resources 'Garnet Lake’ dyke delivers a 2.4 carat diamond; West Greenland diamond potential in the Maniitsoq area confirmed. MINEX 30, 1-2. Copenhagen: Geological Survey of Denmark and Greenland, and Nuuk: Bureau of Minerals and Petroleum.

MINEX 2007b: (1) International Molybdenum Pic ('InterMoly'), (2) Ironbark Gold identify new zones of high grade zinc in Citronen Fjord;. MINEX 31, 1-7. Copenhagen: Geological Survey of Denmark and Greenland, and Nuuk: Bureau of Minerals and Petroleum.

MINEX 2008a: New diamond prospective area in Greenland. MINEX 32, 1. Copenhagen: Geological Survey of Denmark and Greenland, and Nuuk: Bureau of Minerals and Petroleum.

MINEX 2008b: (1) Diamond potential in the Disko Bay area strengthened, (2) Major resource upgrade at Citronen Fjord zinc deposit, (3) Black Angel Mine to re-open, (4) Malmbjerg molybdenum: approval of mine permit. MINEX 33, 1-5. Copenhagen: Geological Survey of Denmark and Greenland, and Nuuk: Bureau of Minerals and Petroleum.
Moncrieff, A.C.M. 1989: The Tillite Group and related rocks of East Greenland: implications for Late Proterozoic palaeogeography. In: Gayer, R.A. (ed.): The Caledonide geology of Scandinavia, 285-297. London: Graham \& Trotman.

Moorbath, S., O'Nions, R.K., Pankhurst, R.J., Gale, N.H. \& McGregor, V.R. 1972: Further rubidium-strontium age determinations on the very early Precambrian rocks of the Godthåb district, West Greenland. Nature Physical Sciences 240, 78-82.

Moorbath, S., O`Nions, R.K. \& Pankhurst, R.J. 1973: Early Archaean age for the Isua iron formation, West Greenland. Nature Physical Sciences 245, 138-139.

Myers, J.S. 1978: Formation of banded gneisses by deformation of igneous rocks. Precambrian Research 6, 43-64.

Myers, J.S. 1985: Stratigraphy and structure of the Fiskenæsset Complex, southern West Greenland. Bulletin Grønlands Geologiske Undersøgelse 150, 72 pp.

Neben, S., Damm, V., Brent, T.[A.] \& Tessensohn, F. 2006: New multichannel seismic reflection data from Northwater Bay, Nares Strait: indications for pull-apart tectonics. Polarforschung 74, 77-96.

Nielsen, B.L. 1976: Economic minerals. In: Escher, A. \& Watt, W.S (eds): Geology of Greenland, 461-486. Copenhagen: Geological Survey of Greenland.

Nielsen, T.F.D. 1978: The Tertiary dike swarms of the Kangerdlugssuaq area, East Greenland. An example of magmatic development during continental break-up. Contributions to Mineralogy and Petrology 67, 63-78.

Nielsen, T.F.D. 1987: Tertiary alkaline magmatism in East Greenland: a review. In: Fitton, J.G. \& Upton, B.G.J. (eds): Alkaline igneous rocks. Geological Society Special Publication (London) 30, 489-515.

Nielsen, T.F.D. \& Brooks, C.K. 1981: The E Greenland rifted continental margin: an examination of the coastal flexure. Journal of the Geological Society (London) 138, 559-568.

Nielsen, T.F.D. \& Rosing, M.T. 1990: The Archaean Skjoldungen alkaline province, South-East Greenland. Rapport Grønlands Geologiske Undersøgelse 148, 93-100.

Nielsen, T.F.D., Soper, N.J., Brooks, C.K., Faller, A.M., Higgins, A.C. \& Matthews, D.W. 1981: The pre-basaltic sediments and the Lower Basalts at Kangerdlugssuaq, East Greenland: their stratigraphy, lithology, palaeomagnetism and petrology. Meddelelser om Grønland Geoscience 6, 25 pp.

Nielsen, T.F.D., Jensen, S.M., Secher, K. \& Sand, K.K. 2009: Distribution of kimberlite and aillikite in the Diamond Province of southern West Greenland: a regional perspective based on groundmass mineral chemistry and bulk compositions. Lithos, http://dx.doi.org/10.1016/j.lithos.2009.05.035.

Nøhr-Hansen, H. 2003: Dinoflagellate cyst stratigraphy of the Palaeogene strata from the Hellefisk-1, Ikermiut-1, Kangâmiut1, Nukik-1, Nukik-2 and Qulleq-1 wells, offshore West Greenland. Marine and Petroleum Geology 20, 287-1016.

Núñez-Betelu, L.K. 1993: Rock-Eval/TOC pyrolysis data from the Kanguk Formation (Upper Cretaceous), Axel Heiberg and Ellesmere Islands, Canadian Arctic. Geological Survey of Canada, Open-File report 2727, $31 \mathrm{pp}$

Nutman, A.P. 1984: Precambrian gneisses and intrusive anorthosite 
of Smithson Bjerge, Thule district, North-West Greenland. Rapport Grønlands Geologiske Undersøgelse 119, 31 pp.

Nutman, A.P. \& Friend, C.R.L. 2007: Adjacent terranes with ca. 2715 and $2650 \mathrm{Ma}$ high-pressure metamorphic assemblages in the Nuuk region of the North Atlantic Craton, southern West Greenland: complexities of Neoarchaean collisional orogeny. Precambrian Research 155, 159-203.

Nutman, A.P. \& Friend, C.R.L. 2009: New 1:20,000 scale geological maps, synthesis and history of investigation of the Isua supracrustal belt and adjacent orthogneisses, southern West Greenland: a glimpse of Eoarchaean crust formation and orogeny. Precambrian Research 172, 189-211. http://doi:101016/j.precamres.2009.03.017.

Nutman, A.P. \& Kalsbeek, F. 1994: A minimum age of $2944 \pm 7$ Ma for the Târtoq Group, South-West Greenland. Rapport Grønlands Geologiske Undersøgelse 161, 35-38.

Nutman, A.P., Bridgwater, D. \& Fryer, B.J. 1984: The iron-rich suite from the Amitsoq gneisses of southern West Greenland: early Archaean plutonic rocks of mixed crustal and mantle origin. Contributions to Mineralogy and Petrology 87, 24-34.

Nutman, A.P., McGregor, V.R., Friend, C.R.L., Bennett, V.C. \& Kinny, P.D. 1996: The Itsaq Gneiss Complex of southern West Greenland; the world's most extensive record of early crustal evolution (3900-3600 Ma). Precambrian Research 78, 1-39.

Nutman, A.P., Kalsbeek, F., Marker, M., van Gool, J.A.M. \& Bridgwater, D. 1999: U-Pb zircon ages of Kangâmiut dykes and detrital zircons in metasediments in the Palaeoproterozoic Nagssugtoqidian Orogen (West Greenland): clues to the pre-collisional history of the orogen. Precambrian Research 93, 87-104.

Nutman, A.P., Friend, C.R.L., Barker, S.L.L. \& McGregor, V.R. 2004: Inventory and assessment of Palaeoarchaean gneiss terrains and detrital zircons in southern West Greenland. Precambrian Research 135, 281-314.

Nutman, A.P., Dawes, P.R., Kalsbeek, F. \& Hamilton, M.A. 2008a: Palaeoproterozoic and Archaean gneiss complexes in northern Greenland: Palaeoproterozoic terrane assembly in the High Arctic. Precambrian Research 161, 419-451.

Nutman, A.P., Kalsbeek, F. \& Friend, C.R.L. 2008b: The Nagssugtoqidian orogen in South-East Greenland: evidence for Palaeoproterozoic collision and plate assembly. American Journal of Science 308, 539-572.

Nyegaard, P. 1979: Evaluation of uranium deposit at Kvanefjeld, 39 pp., 3 app. Unpublished report, Geological Survey of Greenland, Copenhagen (in archives of Geological Survey of Denmark and Greenland, GEUS Report File 16977).

Oakey, G.N. 2005: Cenozoic evolution and lithosphere dynamics of the Baffin Bay - Nares Strait region of Arctic Canada and Greenland, 233 pp. Unpublished Ph.D. thesis, Vrije Universiteit, Amsterdam, The Netherlands.

Ohmura, A. \& Reeh, N. 1991: New precipitation and accumulation maps for Greenland. Journal of Glaciology 37(125), 140-148.

Olsen, H. 1993: Sedimentary basin analysis of the continental Devonian basin in North-East Greenland. Bulletin Grønlands Geologiske Undersøgelse 168, 80 pp.

Olsen, H. \& Larsen, P.-H. 1993: Lithostratigraphy of the continen- tal Devonian sediments in North-East Greenland. Bulletin Grønlands Geologiske Undersøgelse 165, 108 pp.

Ostenso, N.A. \& Wold, R.J. 1977: A seismic and graviy profile across the Arctic Ocean Basin. Tectonophysics 37, 1-24.

Paslick, C.R., Halliday, A.N., Davies, G.R., Mezger, K. \& Upton, B.G.J. 1993: Timing of Proterozoic magmatism in the Gardar Province, southern Greenland. Geological Society of America Bulletin 105, 272-278.

Patchett, P.J. \& Bridgwater, D. 1984: Origin of continental crust of 1.9-1.7 Ga age defined by Nd isotopes in the Ketilidian terrain of South Greenland. Contributions to Mineralogy and Petrology 87, 311-318.

Pauly, H. \& Bailey, J.C. 1999: Genesis and evolution of the Ivigtut cryolite deposit, SW Greenland. Meddelelser om Grønland Geoscience 37, 60 pp.

Pedersen, A.K. 1985a: Lithostratigraphy of the Tertiary Vaigat Formation on Disko, central West Greenland. Rapport Grønlands Geologiske Undersøgelse 124, 30 pp.

Pedersen, A.K. 1985b: Reaction between picrite magma and continental crust: early Tertiary silicic basalts and magnesian andesites from Disko, West Greenland. Bulletin Grønlands Geologiske Undersøgelse 152, 126 pp.

Pedersen, A.K., Larsen, L.M. \& Dueholm, K.S. 1993: Geological section along the south coast of Nuussuaq, central West Greenland, 1:20 000, coloured sheet. Copenhagen: Geological Survey of Greenland.

Pedersen, A.K., Larsen, L.M., Pedersen, G.K. \& Dueholm, K.S. 1996: Filling and plugging of a marine basin by volcanic rocks: the Tunoqqu Member of the Lower Tertiary Vaigat Formation on Nuussuaq, central West Greenland. Bulletin Grønlands Geologiske Undersøgelse 171, 5-28.

Pedersen, A.K., Watt, M., Watt, W.S. \& Larsen, L.M. 1997: Structure and stratigraphy of the Early Tertiary basalts of the Blosseville Kyst, East Greenland. Journal of the Geological Society (London) 154, 565-570.

Pedersen, A.K., Larsen, L.M., Pedersen, G.K. \& Dueholm K.S. 2006: Five slices through the Nuussuaq Basin, West Greenland. Bulletin Geological Survey of Denmark and Greenland 10, 53-56.

Pedersen, A.K., Pedersen, G.K., Larsen, L.M., Pulvertaft, T.C.R., Sønderholm, M. \& Dueholm, K.S. 2007: Geological map of the south-east coast of Nuussuaq between Ataata Kuua and Saqqaqdalen, central West Greenland, 1:50 000, with detailed sections. Copenhagen: Geological Survey of Denmark and Greenland.

Pedersen, G.K., Larsen, L.M., Pedersen, A.K. \& Hjortkjær, B.F. 1998: The syn-volcanic Naajaat lake, Paleocene of West Greenland. Palaeogeography, Palaeoclimatology, Palaeoecology 140, 271-287.

Pedersen, S.A.S. 1986: A transverse, thin skinned, thrust fault belt in the Paleozoic North Greenland Fold Belt. Geological Society of America Bulletin 97, 1442-1455.

Pedersen, S.A.S., Craig, L.E., Upton, B.G.J., Rämö, O.T., Jepsen, H.F. \& Kalsbeek, F. 2002: Palaeoproterozoic (1740 Ma) riftrelated volcanism in the Hekla Sund region, eastern North Greenland: field occurrence, geochemistry and tectonic setting. Precambrian Research 114, 327-346.

Peel, J.S. 1982: The Lower Paleozoic of Greenland. In: Embry, A.F. 
\& Balkwill, H.R. (eds): Arctic geology and geophysics. Canadian Society of Petroleum Geologists Memoir 8, 309-330.

Peel, J.S. \& Cowie, J.W. 1979: New names for Ordovician formations in Greenland. In: Peel, J.S. (compiler): Lower Palaeozoic stratigraphy and palaeontology: shorter contributions. Rapport Grønlands Geologiske Undersøgelse 91, 117-124.

Peel, J.S. \& Secher, K. 1979: A second fossil occurrence from the Precambrian Shield of southern West Greenland. In: Peel, J.S. (compiler): Lower Palaeozoic stratigraphy and palaeontology: shorter contributions. Rapport Grønlands Geologiske Undersøgelse 91, 99-104.

Peel, J.S. \& Sønderholm, M. (eds) 1991: Sedimentary basins of North Greenland. Bulletin Grønlands Geologiske Undersøgelse 160, $164 \mathrm{pp}$.

Phillips, W.E.A. \& Friderichsen, J.D. 1981: The Late Precambrian Gåseland tillite, Scoresby Sund, East Greenland. In: Hambrey, A.J. \& Harland, W.B. (eds): Earth's pre-Pleistocene glacial record, 773-775. Cambridge: Cambridge University Press.

Pidgeon, R.T. \& Kalsbeek, F. 1978: Dating of igneous and metamorphic events in the Fiskenæsset region of southern West Greenland. Canadian Journal of Earth Sciences 15, 2021-2025.

Pidgeon, R.T., Aftalion, M. \& Kalsbeek, F. 1976: The age of the Ilivertalik granite in the Fiskenæsset area. Rapport Grønlands Geologiske Undersøgelse 73, 31-33.

Polat, A. \& Hofmann, A.W. 2003: Alteration and geochemical patterns in the 3.7-3.8 Ga Isua greenstone belt, West Greenland. Precambrian Research 126, 197-218.

Polat, A., Hofmann, A.W. \& Rosing, M.T. 2002: Boninite-like volcanic rocks in the 3.7-3.8 Ga Isua greenstone belt: geochemical evidence for intra-oceanic subduction zone processes in the early Earth. Chemical Geology 184, 231-254.

Poulsen, V. 1964: The sandstones of the Precambrian Eriksfjord Formation in South Greenland. Rapport Grønlands Geologiske Undersøgelse 2, 16 pp.

Pulvertaft, T.C.R. 1986: The development of thin thrust sheets and basement-cover sandwiches in the southern part of the Rinkian belt, Umanak district, West Greenland. In: Kalsbeek, F. \& Watt, W.S. (eds): Developments in Greenland geology. Rapport Grønlands Geologiske Undersøgelse 128, 75-87.

Pulvertaft, T.C.R. 1997: History of petroleum exploration and summary of potential petroleum basins in Greenland. Danmarks og Grønlands Geologiske Undersøgelse Rapport 1997/62, 19 pp.

Pulvertaft, T.C.R. 2008: Field relations, petrography and chronology of the component units of the western part of the Palaeoproterozoic Julianehåb batholith, South Greenland. Danmarks og Grønlands Geologiske Undersøgelse Rapport 2008/70, 55 pp.

Ramberg, H. 1949: On the petrogenesis of the gneiss complexes between Sukkertoppen and Christianshaab, West-Greenland. Meddelelser fra Dansk Geologisk Forening 11, 312-327.

Reid, I. \& Jackson, H.R. 1997: Crustal structure of northern Baffin Bay: seismic refraction results and tectonic implications. Journal of Geophysical Research 102(B1), 523-542.

Ritzmann, O. \& Jokat, W. 2003: Crustal structure of northwestern Svalbard and the adjacent Yermak Plateau: evidence for Oligocene detachment tectonics and non-volcanic breakup. Geophysical
Journal International 152, 139-159.

Roest, W.R. \& Srivastava, S.P. 1989: Sea-floor spreading in the Labrador Sea: a new reconstruction. Geology 17, 1000-1003.

Roots, W.D. \& Srivastava, S.P. 1984: Origin of the marine magnetic quiet zones in the Labrador and Greenland Seas. Marine Geophysical Researches 6, 395-408.

Rosing, M.T. 1999: 13C depleted carbon microparticles in >3700Ma sea-floor sedimentary rocks from West Greenland. Science 238, 674-676.

Rosing, M.T., Nutman, A.P. \& Løfqvist, L. 2001: A new fragment of the early earth crust: the Aasivik terrane of West Greenland. Precambrian Research 105, 115-128.

Samuelsson, J., Dawes, P.R. \& Vidal, G. 1999: Organic-walled microfossils from the Proterozoic Thule Supergroup, Northwest Greenland. Precambrian Research 96, 1-23.

Schiener, E.J. 1976: Coal geology. In: Escher, A. \& Watt, W.S. (eds): Geology of Greenland, 506-516. Copenhagen: Geological Survey of Greenland.

Schønwandt, H.K. \& Dawes, P.R. 1993: An overview of Greenland's mineral exploration potential. Rapport Grønlands Geologiske Undersøgelse 159, 10-16.

Scott, B.H. 1981: Kimberlite and lamproite dykes from Holsteinsborg, West Greenland. Meddelelser om Grønland Geoscience 4, 24 pp.

Secher, K. 1983: Noritic rocks and associated nickel-copper-sulphide occurrences in Sukkertoppen district, central West Greenland. Rapport Grønlands Geologiske Undersøgelse 115, 30-34.

Secher, K. \& Appel, P. 2007: Gemstones of Greenland. Geology and Ore 7, 12 pp.

Secher, K. \& Jensen, S.M. 2004: Diamond exploration in Greenland. Geology and Ore 4, 12 pp.

Secher, K. \& Larsen, L.M. 1980: Geology and mineralogy of the Sarfartôq carbonatite complex, southern West Greenland. Lithos 13, 199-212.

Secher, K., Appel, P. \& Nielsen, T.F.D. 2007: The PGE potential in Greenland. Geology and Ore 8. 12 pp.

Secher, K., Stendal, H. \& Stensgaard, B.M. 2008: The Nalunaq gold mine. Geology and Ore 12, 12 pp.

Secher, K., Heaman, L.M., Nielsen, T.F.D., Jensen, S.M., Schjøth, F. \& Creaser, R.A. 2009: Timing of kimberlite, carbonatite, and ultramafic lamprophyre emplacement in the alkaline province located $64^{\circ}-67^{\circ} \mathrm{N}$ in southern West Greenland. Lithos, http://dx.doi.org/10.1016/j.lithos.2009.04.035, 7 pp.

Shekhar, S.C., Frandsen, N. \& Thomsen, E. 1982: Coal on Nûgssuaq, West Greenland, 82 pp., 88 encl. Unpublished report, Geological Survey of Greenland, Copenhagen (in archives of Geological Survey of Denmark and Greenland, GEUS Report File 16978).

Skaarup, N. 2007: Distribution of sediments along the Kangâmiut Ridge, offshore southern West Greenland. Marine and Petroleum Geology 24, 43-52.

Smith, M.P. \& Rasmussen, J.A. 2008: Cambrian-Silurian development of the Laurentian margin of the Iapetus Ocean in Greenland and related areas. In: Higgins, A.K., Gilotti, J.A. \& Smith, M.P. (eds): The Greenland Caledonides: evolution of the northeast margin of Laurentia. Geological Society of America Memoir 202, $137-167$. 
Smith, M.P. \& Robertson, S. 1999: The Nathorst Land Group (Neoproterozoic) of East Greenland - lithostratigraphy, basin geometry and tectonic history. In: Higgins, A.K. \& Frederiksen, K.S. (eds): Geology of East Greenland $72^{\circ}-75^{\circ} \mathrm{N}$, mainly Caledonian: preliminary reports from the 1998 expedition. Danmarks og Grønlands Geologiske Undersøgelse Rapport 1999/19, 127-143.

Smith, M.P., Rasmussen, J.A., Robertson, S., Higgins, A.K. \& Leslie, A.G. 2004: Lower Palaeozoic stratigraphy of the East Greenland Caledonides. In: Higgins, A.K. \& Kalsbeek, F. (eds): East Greenland Caledonides: stratigraphy, structure and geochronology.Geological Survey of Denmark and Greenland Bulletin 6, 5-28.

Sobczak, L.W. \& Stephens, L.E. 1974: The gravity field of northern Ellesmere Island, part of northern Greenland and Lincoln Sea with map: Lincoln Sea 1:500 000. Earth Physics Branch, Gravity Map Series 114, 9 pp.

Sønderholm, M. \& Harland, T.L. 1989: Franklinian Reef Belt, Silurian, North Greenland. In: Geldsetzer, H.H.J., James, N.P. \& Tebbutt, G.E. (eds): Reefs, Canada and adjacent area. Canadian Society of Petroleum Geologists Memoir 13, 356-366.

Sønderholm, M. \& Jepsen, H.F. 1991: Proterozoic basins of North Greenland. In: Peel, J.S. \& Sønderholm, M. (eds): Sedimentary basins of North Greenland. Bulletin Grønlands Geologiske Undersøgelse 160, 49-69.

Sønderholm, M. \& Tirsgaard, H. 1993: Lithostratigraphic framework of the Upper Proterozoic Eleonore Bay Supergroup of East and North-East Greenland. Bulletin Grønlands Geologiske Undersøgelse 167,38 pp.

Sønderholm, M., Frederiksen, K.S., Smith, M.P. \& Tirsgaard, H. 2008: Neoproterozoic sedimentary basins with glacigenic deposits of the East Greenland Caledonides. In: Higgins, A.K., Gilotti, J.A. \& Smith, M.P. (eds): The Greenland Caledonides: evolution of the northeast margin of Laurentia. Geological Society of America Memoir 202, 99-136.

Soper, N.J. \& Higgins, A.K. 1987: A shallow detachment beneath the North Greenland fold belt: implications for sedimentation and tectonics. Geological Magazine 124, 441-450.

Soper, N.J. \& Higgins, A.K. 1990: Models for the Ellesmerian mountain front in North Greenland: a basin margin inverted by basement uplift. Journal of Structural Geology 12, 83-97.

Soper, N.J., Higgins, A.C., Matthews, D.W. \& Brown, P.E. 1976: Late Cretaceous - early Tertiary stratigraphy of the Kangerdlugssuaq area, east Greenland, and the age of the opening of the NorthAtlantic. Journal of the Geological Society (London) 132, 85-104.

Sørensen, A.B. 2006: Stratigraphy, structure and petroleum potential of the Lady Franklin and Maniitsoq basins, offshore southern West Greenland. Petroleum Geoscience 12, 221-234.

Sørensen, H. 2006a: The Ilímaussaq alkaline complex, South Greenland - an overview of 200 years of research and an outlook. Contribution the mineralogy of Ilímaussaq no. 130. Meddelelser om Grønland Geoscience 45, 70 pp.

Sørensen, H. (ed.) 2006b: Geological guide. South Greenland. The Narsarsuaq - Narsaq - Qaqortoq region, 132 pp. Copenhagen: Geological Survey of Denmark and Greenland.

Sørensen, K., Korstgård, J.A., Glassley, W.E. \& Stensgaard, B.M.
2006: The Nordre Strømfjord shear zone and the Arfersiorfik quartz diorite in Arfersiorfik, the Nagssugtoqidian orogen, West Greenland. In: Garde, A.A. \& Kalsbeek, F. (eds): Precambrian crustal evolution and Cretaceous-Palaeogene faulting in West Greenland. Geological Survey of Denmark and Greenland Bulletin 11, 145-161.

Srivastava, S.P. 1978: Evolution of the Labrador Sea and its bearing on the early evolution of the North Atlantic. Geophysical Journal of the Royal Astronomical Society 52, 313-357.

Srivastava, S.P. 1983: Davis Strait: structures, origin and evolution. In: Bott, M.H.P. et al. (eds): Structure and development of the Greenland-Scotland ridge, 159-189. New York: Plenum Press.

Srivastava, S.P. 1985: Evolution of the Eurasian Basin and its implications to the motion of Greenland along Nares Strait. Tectonophysics 114, 29-53.

Srivastava, S.P. \& Roest, W.R. 1999: Extent of oceanic crust in the Labrador Sea. Marine and Petroleum Geology 16, 65-84.

Srivastava, S.P., Falconer, R.K.H. \& MacLean, B. 1981: Labrador Sea, Davis Strait, Baffin Bay: geology and geophysics - a review. In: Kerr, J.W. \& Fergusson, A.J. (eds): Geology of the North Atlantic borderlands. Canadian Society of Petroleum Geologists Memoir 7, 333-398.

Stecher, O. \& Henriksen, N. 1994: Sm-Nd model age of an early Proterozoic gabbro-anorthosite from the Caledonian fold belt in North-East Greenland. In: Higgins, A.K. (ed.): Geology of NorthEast Greenland. Rapport Grønlands Geologiske Undersøgelse 162, 135-137.

Steck, A. 1971: Kaledonische Metamorphose der praekambrischen Charcot Land Serie, Scoresby Sund, Ost-Grönland. Bulletin Grønlands Geologiske Undersøgelse 97, 69 pp. (also Meddelelser om Grønland 192(3)).

Steenfelt, A., Hollis, J.A. \& Secher, K. 2006: The Tikiussaq carbonatite: a new Mesozoic intrusive complex in southern West Greenland. Geological Survey of Denmark and Greenland Bulletin 10, 41-44.

Steiger, R.H., Harnik-Soptrajanova, G., Zimmermann, E. \& Henriksen, N. 1976: Isotopic age and metamorphic history of the banded gneiss at Danmarkshavn, east Greenland. Contributions to Mineralogy and Petrology 57, 1-24.

Steiger, R.H., Hansen, B.T., Schuler, C.H., Bär, M.T. \& Henriksen, N. 1979: Polyorogenic nature of the southern Caledonian fold belt in East Greenland; an isotopic age study. Journal of Geology 87, 475-495.

Stemmerik, L. 2000: Late Palaeozoic evolution of the North Atlantic margin of Pangea. Palaeogeography, Palaeoclimatology, Palaeoecology 161, 95-126.

Stemmerik, L. \& Håkansson, E. 1989: Stratigraphy and depositional history of the Upper Palaeozoic and Triassic sediments in the Wandel Sea Basin, central and eastern North Greenland. Rapport Grønlands Geologiske Undersøgelse 143, 21-45.

Stemmerik, L. \& Håkansson, E. 1991: Carboniferous and Permian history of the Wandel Sea Basin, North Greenland. In: Peel, J.S. \& Sønderholm, M. (eds): Sedimentary basins of North Greenland. Bulletin Grønlands Geologiske Undersøgelse 160, 141-151.

Stemmerik, L. \& Stouge, S. (eds) 2004: The Jurassic of North-East 
Greenland. Geological Survey of Denmark and Greenland Bulletin 5, 112 pp.

Stemmerik, L. \& Worsley, D. 2005: 30 years on - Arctic Upper Palaeozoic stratigraphy, depositional evolution and hydrocarbon prospectivity. Norwegian Journal of Geology 85, 151-168.

Stemmerik, L., Vigran, J.O. \& Piasecki, S. 1991: Dating of late Paleozoic rifting events in the North Atlantic: new biostratigraphic data from the uppermost Devonian and Carboniferous of East Greenland. Geology 19, 218-221.

Stemmerik, L., Christiansen, F.G., Piasecki, S., Jordt, B., Marcussen, C. \& Nøhr-Hansen, H. 1993: Depositional history and petroleum geology of the Carboniferous to Cretaceous sediments in the northern part of East Greenland. In: Vorren, T.O. et al. (eds): Arctic geology and petroleum potential. Norwegian Petroleum Society Special Publication 2, 67-87.

Stemmerik, L., Håkansson, E., Madsen, L., Nilsson, I., Piasecki, S., Pinard, S. \& Rasmussen, J.A. 1996: Stratigraphy and depositional evolution of the Upper Palaeozoic sedimentary succession in eastern Peary Land, North Greenland. Bulletin Grønlands Geologiske Undersøgelse 171, 45-71.

Stemmerik, L., Sønderholm, M. \& Bojesen-Koefoed, J.A. 1997: Palaeo-oil field in a Silurian carbonate buildup, Wulff Land, North Greenland: project 'Resources of the sedimentary basins of North and East Greenland'. Geology of Greenland Survey Bulletin 176, 24-28.

Stemmerik, L., Dalhoff, F., Larsen, B.D., Lyck, J., Mathiesen, A. \& Nilsson, I. 1998: Wandel Sea Basin, eastern North Greenland. Geology of Greenland Survey Bulletin 180, 55-62.

Stemmerik, L., Larsen, B.D. \& Dalhoff, F. 2000: Tectono-stratigraphic history of northern Amdrup Land, eastern North Greenland: implications for the northernmost East Greenland shelf. In: Stemmerik, L. (ed.): Palynology and deposition in the Wandel Sea Basin, eastern North Greenland. Geology of Greenland Survey Bulletin 187, 7-19.

Steenfelt, A. 1994: Large scale geochemical variation in the Precambrian of West and South Greenland. Rapport Grønlands Geologiske Undersøgelse 160, 41-44.

Steenfelt, A. 2000: Geochemical signatures of gold provinces in South Greenland. Transactions Institution of Mining and Metallurgy (Section B: Applied earth science) 109, B14-B22.

Steenfelt, A. 2001: Geochemical atlas of Greenland - West and South Greenland. Danmarks og Grønlands Geologiske Undersøgelse Rapport 2001/46, 39 pp., 1CD-ROM.

Steenfelt, A., Stendal, H., Nielsen, B.M. \& Rasmussen, T.M. 2004: Gold in central West Greenland - known and prospective occurrences. Geological Survey of Denmark and Greenland Bulletin 4, 65-68.

Steenfelt, A., Hollis, J.A. \& Secher, K. 2006: The Tikiusaaq carbonatite: a new Mesozoic intrusive complex in southern West Greenland. Geological Survey of Denmark and Greenland Bulletin 10, 41-44.

Stendal, H. \& Frei, R. 2000: Gold occurrences and lead isotopes in the Ketilidian Mobile Belt, South Greenland. Transaction Institution of Mining and Metallurgy (Section B: Applied earth science) 109, B6-B13.
Stendal, H. \& Secher, K. 2002: Gold mineralisation and gold potential in South Greenland. Geology and Ore 1, 12 pp.

Stendal, H., Frei, R. \& Stensgaard, B.M. 2006: A lead isotope study of an Archaean gold prospect in the Attu region, Nagssugtoqidian orogen, West Greenland. Geological Survey of Denmark and Greenland Bulletin 11, 53-60.

Stensgaard, B.M. \& Stendal, H. 2007: Gold environments and favourability in the Nuuk area of southern West Greenland. Geology and Ore 9, 12 pp.

Stensgaard, B.M. \& Thorning, L. 2009: Mineral resource assessments in Greenland. Geology and Ore 15, 12 pp.

Stewart, J.W. 1970: Precambrian alkaline-ultramafic/carbonatite volcanism at Qagssiarssuk, South Greenland. Bulletin Grønlands Geologiske Undersøgelse 84, 70 pp. (also Meddelelser om Grønland 186(4)).

St-Onge, M.R., van Gool, J.A.M., Garde, A.A. \& Scott, D.J. 2009: Correlation of Archaean and Palaeoproterozoic units between northeastern Canada and western Greenland: constraining the pre-collosional upper plate accretionary history of the TransHudson orogen. In: Cawood, P.A. \& Kroner, A. (eds): Earth accretionary systems in space and time. Geological Society Special Publication (London) 318, 193-235.

Storey, M., Pedersen, A.K., Larsen, H.C., Larsen, L.M., Stecher, O., Duncan, R.A., Tegner, C. \& Carlson, R.W. 1996: Middle Miocene volcanism in East Greenland. Eos, Transactions, American Geophysical Union 77(46) (Supplement), 823 only.

Storey, M., Duncan, R.A., Pedersen, A.K., Larsen, L.M. \& Larsen, H.C. 1998: ${ }^{40} \mathrm{Ar} /{ }^{39} \mathrm{Ar}$ geochronology of the West Greenland Tertiary volcanic province. Earth and Planetary Science Letters $160,569-586$.

Storey, M., Duncan, R.A. \& Tegner, C. 2007: Timing and duration of volcanism in the North Atlantic Igneous Province: implications for geodynamics and links to the Iceland hotspot. Chemical Geology 241, 264-281.

Stouge, S. \& Peel, J.S. 1979: Ordovician conodonts from the Precambrian shield of southern West Greenland. In: Peel, J.S. (compiler): Lower Palaeozoic stratigraphy and palaeontology: shorter contributions. Rapport Grønlands Geologiske Undersøgelse 91, 105-109.

Strachan, R.A. 1994: Evidence in North-East Greenland for Late Silurian - Early Devonian regional extension during the Caledonian orogeny. Geology 22, 913-916.

Strachan, R.A., Nutman, A.P. \& Friderichsen, J.D. 1995: SHRIMP U-Pb geochronology and metamorphic history of the Smallefjord sequence, NE Greenland Caledonides. Journal of the Geological Society (London) 152, 779-784.

Strachan, R.A., Martin, M.W. \& Friderichsen, J.D. 2001: Evidence for contemporaneous yet contrasting styles of granite magmatism during extensional collapse of the northeast Greenland Caledonides. Tectonophysics 20, 458-473.

Surlyk, F. 1977: Stratigraphy, tectonics and palaeogeography of the Jurassic sediments of the areas north of Kong Oscars Fjord, East Greenland. Bulletin Grønlands Geologiske Undersøgelse 123, 56 pp.

Surlyk, F. 1978: Submarine fan sedimentation along fault scarps on 
tilted fault blocks (Jurassic-Cretaceous boundary, East Greenland). Bulletin Grønlands Geologiske Undersøgelse 128, 108 pp.

Surlyk, F. 1990: Timing, style and sedimentary evolution of Late Palaeozoic - Mesozoic extensional basins of East Greenland. In: Hardman, R.F.P. \& Brooks, J. (eds): Tectonic events responsible for Britain's oil and gas reserves. Geological Society Special Publication (London) 55, 107-125.

Surlyk, F. 1991: Sequence stratigraphy of the Jurassic - lowermost Cretaceous of East Greenland. American Association of Petroleum Geologists Bulletin 75, 1468-1488.

Surlyk, F. 1995: Deep-sea fan valleys, channels, lobes and fringes of the Silurian Peary Land Group, North Greenland. In: Pickering, K. et al. (eds): Atlas of deep water environments: architectural style in turbidite systems, 124-138. London: Chapman \& Hall.

Surlyk, F. 2003: The Jurassic of East Greenland: a sedimentary record of thermal subsidence, onset and culmination of rifting. In: Ineson, J.R. \& Surlyk, F. (eds): The Jurassic of Denmark and Greenland. Geological Survey of Denmark and Greenland Bulletin 1, 659-722.

Surlyk, F. \& Clemmensen, L.B. 1975: A Valanginian turbidite sequence and its palaeogeographical setting (Kuhn $\varnothing$, East Greenland). Bulletin of the Geological Society of Denmark 24, 61-73.

Surlyk, F. \& Hurst, J.M. 1984: The evolution of the early Paleozoic deep-water basin of North Greenland. Geological Society of America Bulletin 95, 131-154.

Surlyk, F. \& Ineson, J.R. 2003: The Jurassic of Denmark and Greenland: key elements in the reconstruction of the North Atlantic Jurassic rift system. In: Ineson, J.R. \& Surlyk, F. (eds): The Jurassic of Denmark and Greenland. Geological Survey of Denmark and Greenland Bulletin 1, 9-20.

Surlyk, F., Clemmensen, L.B. \& Larsen, H.C. 1981: Post-Paleozoic evolution of the East Greenland continental margin. In: Kerr, J.W. \& Fergusson, A.J. (eds): Geology of the North Atlantic borderlands. Canadian Society of Petroleum Geologists Memoir 7, 611-645.

Surlyk, F., Hurst, J.M., Piasecki, S., Rolle, F., Scholle, P.A., Stemmerik, L. \& Thomsen, E. 1986: The Permian of the western margin of the Greenland Sea - a future exploration target. In: Halbouty, M.T. (ed.): Future petroleum provinces of the world. American Association of Petroleum Geologists Memoir 40, 629-659.

Swett, K. \& Smit, D.E. 1972: Paleogeography and depositional environments of the Cambro-Ordovician shallow-marine facies of the North Atlantic. Geological Society of America Bulletin 83, 3223-3248.

Taylor, P.N. \& Kalsbeek, F. 1990: Dating the metamorphism of Precambrian marbles: examples from Proterozoic mobile belts in Greenland. Chemical Geology 86, 21-28.

Taylor, P.N., Jones, N.W. \& Moorbath, S. 1984: Isotopic assessment of relative contributions from crust and mantle sources to the magma genesis of Precambrian granitoid rocks. In: Moorbath, S., Thompson, R.N. \& Oxburg, E.R. (eds): The relative contributions of mantle, oceanic crust and continental crust to magma genesis. Philosophical Transactions of the Royal Society (London) A 310, 605-625.

Tegner, C., Duncan, R.A., Bernstein, S., Brooks, C.K., Bird, D.K. \& Storey, M. 1998: ${ }^{40} \mathrm{Ar}-{ }^{39} \mathrm{Ar}$ geochronology of Tertiary mafic intrusions along the East Greenland rifted margin: relation to flood basalts and the Iceland hotspot track. Earth and Planetary Science Letters 156, 75-88.

Tegner, C., Brooks, C.K., Duncan, R.A., Heister, L.E. \& Bernstein, S. 2008: ${ }^{40} \mathrm{Ar}-{ }^{39} \mathrm{Ar}$ ages of intrusions in East Greenland: rift-todrift transition over the Iceland hotspot. Lithos 101, 480-500.

Tessensohn, F. \& Roland, N.W. 2000: ICAM III. Third international conference on Arctic margins. A preface. Polarforschung 68, 1-9.

Tessensohn, F., Jackson, H.R. \& Reid, I.D. 2006: The tectonic evolution of Nares Strait: implications of new data. Polarforschung 74, 191-198.

Thiede, J., Schäfer, P., Ritzrau, W., Schlüter, M., Schröder-Ritzau and members of SFB 313, 2001: Present and past oceanographic controls of sediment formation in the North Atlantic - Arctic gateway (a critical appraisal of the SFB 313 scientific results). In: Schäfer, P. et al. (eds): The northern North Atlantic, 463-491. Berlin: Springer.

Thomassen, B. 1991: The Black Angel lead-zinc mine 1973-1990. Rapport Grønlands Geologiske Undersøgelse 152, 46-50.

Thomassen, B. 2005: The Blyklippen lead-zinc mine at Mesters Vig, East Greenland. Geology and Ore 5, 12 pp.

Thomassen, B. 2006: The Black Angel lead-zinc mine at Maarmorilik in West Greenland. Geology and Ore 2, 12 pp.

Thomassen, B. \& Nielsen, T.F.D 2006: The mineral potential of the East Greenland Palaeogene intrusions. Geology and Ore 6, 12 pp.

Thorning, L., Larsen, H.C. \& Jacobsen, N.L. 1982: Project EASTMAR - final report, 82 pp. + 3 maps. Unpublished report, Geological Survey of Greenland, Copenhagen (in archives of Geological Survey of Denmark and Greenland, GEUS Report File 16979).

Thrane, K. 2002: Relationships between Archaean and Palaeoproterozoic basement complexes in the southern part of the East Greenland Caledonides: an ion microprobe study. Precambrian Research 113, 19-42.

Thrane, K. \& Connelly, J.N. 2006: Zircon geochronology from the Kangaatsiaq-Qasigiannguit region, the northern part of the 1.9-1.8 Ga Nagssugtoqidian orogen, West Greenland. In: Garde, A.A. \& Kalsbeek, F. (eds): Precambrian crustal evolution and Cretaceous-Palaeogene faulting in West Greenland. Geological Survey of Denmark and Greenland Bulletin 11, 87-99.

Thrane, K., Baker, J., Connelly, J.[N.] \& Nutman, A.[P.] 2005: Age, petrogenesis and metamorphism of the syn-collisional Prøven Igneous Complex, West Greenland. Contributions to Mineralogy and Petrology 149, 541-555.

Tirsgaard, H. \& Øxnevad, I.E.I. 1998: Preservation of pre-vegetational mixed fluvio-aeolian deposits in a humid climatic setting: an example from the Middle Proterozoic Eriksfjord Formation, Southwest Greenland. Sedimentary Geology 120, 295-317.

Tirsgaard, H. \& Sønderholm, M. 1997: Lithostratigraphy, sedimentary evolution and sequence stratigraphy of the Upper Proterozoic Lyell Land Group (Eleonore Bay Supergroup) of East and North-East Greenland. Geology of Greenland Survey Bulletin 178, 60 pp.

Trettin, H.P. (ed.) 1991: Geology of the Innuitian Orogen and Arctic 
Platform of Canada and Greenland. Geology of Canada 3, 569 pp. + map vol. Ottawa: Geological Survey of Canada (also The geology of North America E, Geological Society of America).

Trettin, H.P. 1998: Pre-Carboniferous geology of the northern part of the Arctic Islands: northern Heiberg Fold Belt, Clements Markham Fold Belt, and Pearya; northern Axel Heiberg and Ellesmere islands. Geological Survey of Canada Bulletin 425, 401 pp.

Tsikalas, F., Eldhom, O. \& Faleide, J.I. 2002: Early Eocene sea floor spreading and continent-ocean boundary between Jan Mayen and Senja fracture zones in the Norwegian-Greenland Sea. Marine Geophysical Researches 23, 247-270.

Tsikalas, F., Faleide, J.I., Eldholm, O. \& Wilson, J. 2005: Late Mesozoic - Cenozoic structural and stratigraphical correlation between the conjugate mid-Norwegian and NE Greenland continental margins. In: Doré, A.G. \& Vining, B.A. (eds): Petroleum geology: North-West Europe and global perspectives. Proceedings of the 6th Petroleum Geology Conference, 785-802. London: Geological Society.

Upton, B.G.J. \& Emeleus, C.H. 1987: Mid-Proterozoic alkaline magmatism in southern Greenland: the Gardar province. In: Fitton, J.G. \& Upton, B.G.J. (eds): Alkaline igneous rocks. Geological Society Special Publication (London) 30, 449-471.

Upton, B.G.J., Emeleus, C.H. \& Beckinsale, R.D. 1984: Petrology of the northern East Greenland Tertiary flood basalts: evidence from Hold with Hope and Wollaston Forland. Journal of Petrology 25, 151-184.

Upton, B.G.J., Emeleus, C.H., Rex, D.C. \& Thirlwall, M.F. 1995: Early Tertiary magmatism in NE Greenland. Journal of the Geological Society (London) 152, 959-964.

Upton, B.G.J., Emeleus, C.H., Heaman, L.M., Goodenough, K.M. \& Finch, A.A. 2003: Magmatism of the mid-Proterozoic Gardar Province, South Greenland: chronolgy, petrogenesis and geological setting. Lithos 68, 43-65.

Upton, B.G.J., Rämö, O.T., Heaman, L.M., Blichert-Toft, J., Kalsbeek, F., Barry, T.L. \& Jepsen, H.F. 2005: The Mesoproterozoic ZigZag Dal Basalts and associated intrusions of eastern North Greenland: mantle plume-lithosphere interaction. Contributions to Mineralogy and Petrology 149, 40-56.

van Breemen, O., Aftalion, M. \& Allaart, J.H. 1974: Isotopic and geochronologic studies on granites from the Ketilidian mobile belt of South Greenland. Geological Society of America Bulletin 85, 403-412.

van der Stijl, F.W. \& Mosher, G.Z. 1998: The Citronen Fjord massive sulphide deposit, Peary Land, North Greenland: discovery, stratigraphy, mineralization and structural setting. Geology of Greenland Survey Bulletin 179, 40 pp.

van Gool, J.A.M. \& Marker, M. 2007: Explanatory notes to the Geological map of Greenland, 1:100 000, Ussuit 67 V.2 Nord. Geological Survey of Denmark and Greenland Map Series 3, 40 pp. + map.

van Gool, J.A.M., Connelly, J.N., Marker, M. \& Mengel, F.C. 2002: The Nagssugtoqidian orogen of West Greenland: tectonic evolution and regional correlations from a West Greenland perspective. Canadian Journal of Earth Sciences 39, 665-686.

Verhoef, J., Macnab, R., Roest, W. \& Arjani-Hamed, J. 1996: Magnetic anomalies of the Arctic and North Atlantic oceans and adjacent land areas. GAMMAA5 (Gridded Aeromagnetic and Marine Magnetics of the north Atlantic and Arctic, $5 \mathrm{~km}$ ). Geological Survey of Canada, Open File Report 3125a.

Vidal, G. 1976: Late Precambrian acritarchs from the Eleonore Bay Group and Tillite Group in East Greenland. Rapport Grønlands Geologiske Undersøgelse 78, 19 pp.

Vidal, G. 1979: Acritarchs from the Upper Proterozoic and Lower Cambrian of East Greenland. Bulletin Grønlands Geologiske Undersøgelse 134, 40 pp.

Vogt, P.R. \& Tucholke, B.E. 1989: North Atlantic Ocean basin: aspects of geologic structure and evolution. In: Bally, A.W. \& Palmer, A.R. (eds): The geology of North America; an overview. The geology of North America A, 53-80. Boulder, Colorado: Geological Society of America.

Voss, M. \& Jokat, W. 2007: Continent-ocean transition and voluminous magmatic underplating derived from $P$-wave velocity modelling of the East Greenland continental margin. Geophysical Research International 170, 580-604.

Wager, L.R. \& Deer, W.A. 1939: Geological investigations in East Greenland. Part III. The petrology of the Skaergaard Intrusion, Kangerdlugssuaq, East Greenland. Meddelelser om Grønland 105(4), 1-352.

Watt, G.R. \& Thrane, K. 2001: Early Neoproterozoic events in East Greenland. Precambrian Research 110, 165-184.

Watt, G.R., Kinny, P.D. \& Friderichsen, J.D. 2000: U-Pb geochronology of Neoproterozoic and Caledonian tectonothermal events in the East Greenland Caledonides. Journal of the Geological Society (London) 157, 1031-1048.

Watt, W.S. 1969: The coast-parallel dike swarm of southwest Greenland in relation to the opening of the Labrador Sea. Canadian Journal of Earth Sciences 6, 1320-1321.

Watt, W.S. 1994: Stratigraphy and correlation of the Tertiary plateau basalts in North-East Greenland. In: Higgins, A.K. (ed.): Geology of North-East Greenland. Rapport Grønlands Geologiske Undersøgelse 162, 185-194.

Weidick, A. 1995: Satellite image atlas of glaciers of the world, Greenland. United States Geological Survey Professional Paper 1386-C, 141 pp.

Weis, D., Demaiffe, D., Souchez, A.J., Gow, A.J. \& Meese, D.A. 1997: Ice sheet development in central Greenland: implications from the $\mathrm{Nd}, \mathrm{Sr}$ and $\mathrm{Pb}$ isotopic compositions of basal material. Earth and Planetary Science Letters 150, 161-169.

Weng, W.L. 1995: The area of Greenland and the ice cap. Arctic 48, 206 only.

Wheeler, J.O., Hoffman, P.F., Card, K.D., Davidson, A., Sanford, B.V., Okulitch, A.V. \& Roest, W.R. (compilers) 1996: Geological map of Canada. Geological Survey of Canada, Map 1860A, scale 1:5000 000 .

White, A.P., Hodges, K.V., Martin, M.W. \& Andresen, A. 2002 Geologic constraints on middle-crustal behavior during broadly synorogenic extension in the central East Greenland Caledonides. International Journal of Earth Sciences (Geol. Rundsch.) 91, 187-208.

Whitehouse, M.J., Kamber, B.S. \& Moorbath, S. 1999: Age signif- 
icance of U-Th- $\mathrm{Pb}$ zircon data from early Archaean rocks of West Greenland - a reassessment based on combined ion-microprobe and imaging studies. Chemical Geology 160, 201-224.

Whittaker, R.C., Hamann, N.E. \& Pulvertaft, T.C.R. 1997: A new frontier province offshore northern West Greenland: structure, basin development and petroleum potential of the Melville Bay area. American Association of Petroleum Geologists Bulletin 81, 978-998.

Williamson, M.-C., Larsen, L.M., Jackson, H.R. \& Oakey, G.N. 2003: Evolution of the Baffin Island - West Greenland Tertiary Volcanic Province: evidence from basaltic rocks on the conjugate margins. EGS-AGU-EUG Joint Assembly, Nice, France, April
2003. Geophysical Research Abstracts 5, abstract no. 06113, CDROM only.

Willigers, B.J.A., van Gool, J.A.M., Wijbrans, J.R., Krogstad, E.J. \& Mezger, K. 2002: Posttectonic cooling of the Nagssugtoqidian orogen and a comparison of contrasting cooling histories in Precambrian and Phanerozoic orogens. Journal of Geology 110, 503-517.

Windley, B.F. \& Garde, A.A. 2009: Arc-generated blocks with crustal sections in the North Atlantic craton of West Greenland: new mechanisms of crustal growth in the Archaean with modern analogues. Earth-Science Reviews 93, 1-30.

Witze, A. 2008: Losing Greenland. Nature 452, 798-802. 


\section{Legend explanation}

\section{Geological units}

Onshore: indicated by numbers [1]-[86] in the map legend.

Offshore: indicated by letters $[\mathbf{a}]-[\mathrm{g}]$ and six ornamentations in the map legend.

\section{Onshore}

[1] Sverdrup Basin (undifferentiated). Unit occurs only on Ellesmere Island, Canada.

[2] Pearya - mainly exotic terrane. Unit occurs only in northernmost Ellesmere Island, Canada (p. 49).

[3]-[5] Middle Mesoproterozoic to early Neoproterozoic Thule Supergroup (p. 40), North-West Greenland. Age shown on map legend must be revised according to more recent acritarch studies.

[3] Carbonate and siliciclastic sediments: Narssârssuk Group, NorthWest Greenland (p. 40).

[4] Shales and siltstones: Dundas Group, North-West Greenland.

[5] Sandstones and shales: Smith Sound, Nares Strait and Baffin Bay Groups, North-West Greenland (p. 40).

[6] Palaeogene tholeiitic lavas, central West Greenland (p. 60).

[7] Palaeogene picritic lavas, central West Greenland (p. 60).

[8] Cretaceous-Paleocene sediments: Nuussuaq Group, central West Greenland (p. 57).

[9] Ordovician limestone in fault block in Archaean gneiss. 'Fossilik' locality (Stouge \& Peel 1979), southern West Greenland $\left(65^{\circ} 25^{\prime} \mathrm{N}\right)$ (pp. 71, 75).

[10] Phanerozoic limestones in fault block within reworked Archaean gneiss (Peel \& Secher 1979), southern West Greenland (66 $\left.32^{\prime} \mathrm{N}\right)$.

[11] Basaltic lavas: Eriksfjord Formation, Mesoproterozoic, Gardar Province, South Greenland (p. 38).

[12] Continental sandstones and conglomerates: Eriksfjord Formation, Mesoproterozoic, Gardar Province, South Greenland (p. 38).

[13] Pliocene-Pleistocene sand-silt deposits: Kap København Formation, central North Greenland (p. 62).

[14] Paleocene-Eocene fluviatile and marine sandstones: Thyra $\varnothing$ Formation, Wandel Sea Basin, eastern North Greenland (pp. 54, 55).

[15] Upper Cretaceous sandstones and shales: Herlufsholm Strand Formation and correlatives, Wandel Sea Basin, central and eastern North Greenland (p. 54).

[16] Lower Paleocene basic volcanics and volcanogenic sediments: Kap Washington Group, Wandel Sea Basin, central North Greenland (p. 54).

[17] Upper Jurassic - Lower Cretaceous sandstones and shales: Ladegårdsåen Formation and correlatives, Wandel Sea Basin, central and eastern North Greenland (p. 54).

[18] Upper Permian - Middle Triassic shales and sandstones: Trolle Land Group, Wandel Sea Basin, central and eastern North Greenland (p. 54).

[19] Upper Carboniferous - Lower Permian carbonates: Mallemuk Mountain Group, Wandel Sea Basin, central and eastern North Greenland (p. 54).

[20] Lower Carboniferous sandstones and siltstones: Sortebakker
Formation, Wandel Sea Basin, eastern North Greenland (p. 54).

[21] Silurian carbonates deposited on shelf and slope areas: Washington Land Group, Franklinian Basin, North Greenland (pp. 46, 47).

[22] Silurian sandstones and siltstones deposited in deep-water turbiditic trough: Peary Land Group, Franklinian Basin, North Greenland and Ellesmere Island (pp. 46, 47).

[23] Lower Cambrian - Lower Silurian carbonates from shelf and slope areas: Brønlund Fjord, Tavsen Iskappe, Ryder Gletscher and Morris Bugt Groups, Franklinian Basin, North and North-West Greenland and Ellesmere Island (pp. 45, 46).

[24] Upper part of Lower Cambrian - Lower Silurian mudstones and shales: starved slope and trough deposits, Vølvedal and Amundsen Land Groups, Franklinian Basin, North Greenland and Ellesmere Island (pp. 46, 82).

[25] Lower Cambrian carbonates and siliciclastic sediments; shallowwater deposits: Portfjeld and Buen Formations, Franklinian Basin, North and North-West Greenland and Ellesmere Island (pp. 46).

[26] Upper Neoproterozoic - Lower Cambrian calcareous mudstones and sandy turbidites: Skagen, Paradisfjeld and Polkorridoren Groups, deep-water trough deposits in the Franklinian Basin in North Greenland and on Ellesmere Island (pp. 45, 46).

[27] Neoproterozoic siliciclastic and carbonate sediments: Hagen Fjord Group, North Greenland (p. 41).

[28] Upper Neoproterozoic (Marinoan - uppermost Cryogenian) diamictites and sandstones: Morænesø Formation, central North Greenland (pp. 41, 43).

[29] Neoproterozoic sandstones in Caledonian nappe units: Rivieradal Group, in part older than the Hagen Fjord Group, eastern North Greenland (p. 41).

[30] Mesoproterozoic tholeiitic basalts (1380 Ma): Zig-Zag Dal Basalt Formation, central and eastern North Greenland west of Danmark Fjord (pp. 33, 35). Basalts in Kronprins Christian Land, east of Danmark Fjord, indicated on the map as Zig-Zag Dal Basalt Formation, are 1740 Ma old, i.e. much older.

[31] Palaeo- to Mesoproterozoic sandstones: Independence Fjord Group, central and eastern North Greenland. Shown as Mesoproterozoic on the map legend, but new age dating shows that parts are around $1740 \mathrm{Ma}$ (pp. 33, 35).

[32] Palaeogene (Paleocene-Eocene) plateau basalts: North-East Greenland (p. 61).

[33] Upper Jurassic and Lower Cretaceous shallow marine sandstones: Raukelv, Hesteelv, Lindemans Bugt and Palnatokes Bjerg Formations and Aptian-Albian sediments, central East and North-East Greenland (pp. 56, 57). A revised stratigraphy has been proposed by Surlyk (2003).

[34] Middle-Upper Jurassic marine sandstones and shales: Vardekløft, Olympen, Hareelv and Bernberg Formations, central East and North-East Greenland (pp. 56, 57 ). A revised stratigraphy has 
been proposed by Surlyk (2003).

[35] Upper Triassic - Lower Jurassic lacustrine sandstones and shales: Kap Stewart and Neill Klinter Groups, central East Greenland (p. 56). A revised stratigraphy has been proposed by Surlyk (2003).

[36] Lower-Upper Triassic alluvial sandstones and lacustrine dolomites and shales: Pingo Dal, Gipsdalen and Fleming Fjord Formations, central East Greenland (pp. 56, 57).

[37] Upper Permian - Lower Triassic shallow marine carbonates, sandstones and shales: Foldvik Creek Group and Wordie Creek Formation, central East Greenland (pp. 56, 57).

[38] Carboniferous - Lower Permian fluvial sandstones and shales, central East and North-East Greenland (pp. 53, 55).

[39] Middle-Upper Devonian continental siliciclastic sedimentary rocks: Vilddal, Kap Kolthoff, Kap Graah and Celsius Bjerg Groups, North-East and central East Greenland (pp. 52, 53).

[40] Cambro-Ordovician dominantly limestones and dolomites in the East Greenland Caledonian fold belt: Kløftelv, Bastion, Ella $\varnothing$, Hyolithus Creek, Dolomite Point, Antiklinalbugt, Cape Weber, Narwhale Sound and Heim Bjerge Formations, NorthEast Greenland (p. 50).

[41] Tillites of supposed Marinoan (uppermost Cryogenian) age in isolated occurrences, central East Greenland (p. 43).

[42] Diamictites, sandstones, shales and dolostones in succession of Marinoan - Ediacaran age: Tillite Group in East Greenland Caledonian fold belt, North-East Greenland (pp. 42, 43).

[43] Succession of siliciclastic, calcareous and dolomitic sediments of Neoproterozoic (Cryogenian) age: upper Eleonore Bay Supergroup including Lyell Land, Ymer $\varnothing$ and Andrée Land Groups, East Greenland Caledonian fold belt, North-East Greenland (pp. 42, 43).

[44] Succession of sandstones and siltstones of Neoproterozoic (Tonian-Cryogenian) age: lower Eleonore Bay Supergroup the Nathorst Land Group, East Greenland Caledonian fold belt, North-East Greenland (pp. 42, 43).

[45] Palaeoproterozoic to early Palaeozoic. Mixed basement gneisses, metasedimentary rocks, greenstones, tillites and sedimentary rocks. Exposed in tectonic windows in the East Greenland Caledonian fold belt, North-East Greenland (pp. 31, 43).

[46] Late Mesoproterozoic to early Neoproterozoic metasedimentary rocks in the East Greenland Caledonian fold belt: Krummedal supracrustal sequence and correlative Smallefjord sequence, NorthEast Greenland (pp. 38, 39).

[47] Eocene siliciclastic sedimentary rocks overlying Lower Palaeogene basalts, central and southern East Greenland (p. 62).

[48] Eocene tholeiitic plateau basalts in central and southern East Greenland (p. 61).

[49] Paleocene tholeiitic basalts with picritic intervals, southern East Greenland (p. 61).

[50] Lower Cretaceous - Upper Paleocene sandstones and shales. Pre-basaltic succession in Kangerlussuaq Basin, southern East Greenland (p. 60).

[51] Neogene and Quaternary volcanic rocks in Iceland, predominantly basalt lavas.

[52] Migmatites and gneisses of Palaeoproterozoic to early Neoproterozoic and Caledonian origin in the East Greenland Caledonian fold belt, central East and North-East Greenland (pp.
39, 50) and Ellesmere Island, Canada (p. 49).

[53] Palaeogene felsic intrusions in East Greenland (p. 62).

[54] Late- to post-kinematic granitic s.l. intrusions in the East Greenland Caledonian fold belt, central East and North-East Greenland (pp. 39, 51).

[55] Neoproterozoic augen granite intrusions, deformed during the Caledonian orogeny, central East and North-East Greenland (pp. 38, 39).

[56] Mesoproterozoic intrusive complexes, mainly syenites: Gardar Province, South Greenland (pp. 38, 82).

[57] Palaeogene mafic to intermediate intrusive complexes in East Greenland (p. 62).

[58] Upper Cretaceous gabbroic intrusion. Pearya terrane, Ellesmere Island, Canada.

[59] Middle Jurassic carbonatite complex: Qaqarssuk, southern West Greenland (pp. 44, 82).

[60] Silurian pyroxenitic intrusions in Archaean granulite gneisses: Batbjerg complex, southern East Greenland (p. 51).

[61] Late Neoproterozoic carbonatite complex in Archaean gneisses: Sarfartoq, southern West Greenland (pp. 44, 82).

[62] Palaeoproterozoic metasedimentary rocks (marbles and siliciclastic rocks) in the Rinkian fold belt: Karrat Group comprising the Mârmorilik, Qeqertarssuaq and Nûkavsak Formations, central West Greenland (pp. 25, 26, 81).

[63] Palaeoproterozoic basic metavolcanic rocks: Sortis Group in the northern border zone of the Ketilidian orogen, South-West Greenland (pp. 28, 29).

[64] Palaeoproterozoic metasedimentary rocks: Vallen Group in the northern border zone of the Ketilidian orogen, South-West Greenland (pp. 28, 29).

[65] Palaeoproterozoic acid metavolcanic rocks in the Ketilidian orogen, South Greenland (p. 30).

[66] Archaean acid metavolcanic rocks north-east of Disko Bugt in the Rinkian fold belt, central West Greenland (p. 26).

[67] Palaeoproterozoic, high-grade supracrustal units (paragneisses, marbles, quartzites and basic metavolcanic rocks) in Palaeoproterozoic orogenic belts (pp. 23, 24, 28, 30, 32).

[68] Meso- and Neoarchaean supracrustal rocks (amphibolites and gneissic metasediments) in the Archaean craton, West Greenland and South-East Greenland (pp. 19, 23, 26).

[69] Eoarchaean supracrustal rocks (Isua and Akilia assemblages) in the Archaean craton, southern West Greenland (pp. 17, 18, 80).

[70] Palaeoproterozoic amphibolite facies gneisses (generally orthogneisses) dominantly of juvenile Proterozoic origin. Ketilidian orogen, South and South-East Greenland (pp. 28, 29) and basement in northern part of Caledonian fold belt in North-East Greenland (pp. 31, 32, 38, 50).

[71] Palaeoproterozoic gneisses in granulite facies: Inglefield Land orogenic belt, North-West Greenland and Ellesmere Island, Canada (p. 28); Nagssugtoqidian orogen, South-East Greenland (p. 25) and Caledonian fold belt in North-East Greenland (p. 32).

[72] Meso- and Neoarchaean orthogneisses in amphibolite facies. Archaean craton, southern West Greenland and South-East Greenland (pp. 19, 20).

[73] Meso- and Neoarchaean orthogneisses in granulite facies. Archaean craton, southern West Greenland and South-East Greenland (pp. 19, 20). 
[74] Reworked amphibolite facies Archaean gneisses in Palaeoproterozoic orogens in West and South-East Greenland (pp. 22, 25-27) and in the basement of the southern part of the East Greenland Caledonian fold belt, central East Greenland (pp. 31, 32, 50).

[75] Reworked Archaean granulite facies gneisses in Palaeoproterozoic orogens in central and southern West Greenland (pp. 22, 24) and in South-East Greenland (p. 24).

[76] Eoarchaean gneisses in the core of the Archaean craton in southern West Greenland: 'Amîtsoq gneiss' (p. 18).

[77] Palaeoproterozoic rapakivi 'granites' in the Ketilidian orogen, South Greenland (pp. 28, 30, 38).

[78] Palaeoproterozoic granites: the Julianehåb batholith in the Ketilidian orogen, South Greenland (pp. 28, 29); the Prøven Igneous Complex in the Rinkian fold belt (pp. 26, 27 ) and some granites in the Nagssugtoqidian orogen of southern West and SouthEast Greenland (pp. 24, 25) and within the basement of the Caledonian fold belt in East Greenland (p. 31).

[79] Neoarchaean post-tectonic granite complex: Qôrqut granite, southern West Greenland (p. 21).

[80] Meso- to Neoarchaean granitic to tonalitic plutonic rocks; early-late kinematic intrusions: Taserssuaq tonalite, Ilivertalik augen granite, southern West Greenland (pp. 20, 21, 24). In South-East Greenland syenitic and granitic rocks (p. 21), and an intrusive complex in central West Greenland (p. 26).

[81] Palaeoproterozoic intermediate plutonic rocks in the Nagssugtoqidian orogen: Arfersiorfik quartz diorite at $68^{\circ} \mathrm{N}$, West Greenland (p. 22, 24); Ammassalik intrusive complex and similar rocks in SE Greenland (p. 24, 25). Other occurrences in the Ketilidian orogen in South Greenland (p. 29) and in the Caledonian fold belt in North-East Greenland (p. 32).

[82] Meso- and Neoarchaean post-tectonic intermediate and mafic intrusions in South-East and West Greenland (pp. 21, 26) and North-West Greenland (p. 27).

[83] Neoarchaean alkaline intrusive complex: Skjoldungen alkaline province, South-East Greenland (p. 21).

[84] Mesorchaean carbonatite sheet: Tupertalik, southern West Greenland (pp. 21, 44).
[85] Mesoarchaean anorthositic rocks in the Archaean craton: Fiskenæsset complex and correlatives, southern West Greenland (pp. 19, 80); also in central West Greenland (p. 26), in SouthEast Greenland (p. 24) and in the Thule region $\left(c .77^{\circ} 30^{\prime} \mathrm{N}\right)$ North-West Greenland (p. 27).

[86] Palaeoproterozoic gabbro-anorthosite, East Greenland Caledonian fold belt, North-East Greenland $\left(76^{\circ} \mathrm{N}\right)$ (Stecher \& Henriksen 1994).

\section{Offshore}

[a] Areas underlain by continental crust with or without cover of sedimentary rocks and Tertiary volcanic rocks (p. 66).

[b] Transition zone between continental and oceanic crust. In many areas thought to consist of continental crust with increasing intensity of dykes and intrusions as oceanic crust is approached (p. 66). Off South-West Greenland transition zone is extremely thin continental crust flanked to the south-west by a zone of serpentinised mantle peridotite.

[c]-[f] Areas underlain by oceanic crust, divided according to age at 15 million year intervals. Oldest oceanic crust [f] was formed more than 45 million years ago. Divisions based on sea-floor spreading magnetic anomalies (p. 66).

[g] Oceanic crust of unspecified age (pp. 66, 70).

\section{Ornamentations}

Palaeogene volcanic rocks at seabed or concealed, latter only shown in areas underlain by continental crust: North-East Greenland $72-75^{\circ} \mathrm{N}$ (p. 74); West and North-West Greenland $68-73^{\circ} \mathrm{N}$ (p. 76).

Buried volcano with high relief, central East Greenland, $69^{\circ} \mathrm{N}$.

Intrusions in sedimentary and volcanic rocks, East Greenland $\left(71-73^{\circ} \mathrm{N}\right)$. Probably of Palaeogene age (p. 74).

Areas with widespread salt deposits of supposed Late Palaeozoic age, North-East Greenland shelf 76030'-79³0’ N (p. 73).

Sedimentary basins with thicknesses over $4 \mathrm{~km}$ (pp. 73-77). Most sediments are of Late Palaeozoic - Cenozoic age.

Little known basins with thick sedimentary successions (pp. 73, $74,76,77)$. 


\section{Place names register}

Includes all place names shown on the geological map. The names in square brackets are some well-known alternative names that do not appear on the map.

Map segment numbers refer to the index map on page 10 (Fig. 1).

In the alphabetical sorting the Danish letters Æ, $\varnothing$ and $\AA$ are treated as $\mathrm{AE}, \mathrm{O}$ and $\mathrm{A}$; for convenience Øfjord also follows $\mathrm{Z}$.

Lat./ Long. $\begin{gathered}\text { Map } \\ \text { Place name }\end{gathered}$
segment

A

Aasiaat
Akia
Alert (Canada)
Alluitsup Paa
Ameralik [Lysefjord]
Ammassalik
Anap Nunaa
Andreé Land
Ardencaple Fjord
Arfersiorfik
Arsuk
Atammik
Attu
B
Bache Peninsula (Canada)
Baffin Bugt
Bessel Fjord
Bildsøe Nunatakker
Bjørnesund
Blosseville Kyst
Bredefjord
Breitafjörður (Iceland)

C

Camp Century

Canning Land

Carey Øer

Charcot Land

Christianshåb

Clavering Ø

Constable Pynt

\author{
Daneborg \\ Danell Fjord [Iluileq] \\ Danmark Fjord \\ Danmark Stræde \\ Danmarkshavn \\ Davis Stræde \\ Disko \\ Disko Bugt \\ Dome GRIP (Summit)
}

$\begin{array}{lr}68^{\circ} 43^{\prime} / 52^{\circ} 53^{\prime} & 6 \\ 64^{\circ} 24^{\prime} / 51^{\circ} 43^{\prime} & 7 \\ 82^{\circ} 30^{\prime} / 62^{\circ} 09^{\prime} & 5 \\ 60^{\circ} 28^{\prime} / 45^{\circ} 34^{\prime} & 7 \\ 64^{\circ} 07^{\prime} / 51^{\circ} 00^{\prime} & 7 \\ 65^{\circ} 36^{\prime} / 37^{\circ} 38^{\prime} & 10 \\ 69^{\circ} 57^{\prime} / 50^{\circ} 30^{\prime} & 6 \\ 73^{\circ} 42^{\prime} / 26^{\circ} 25^{\prime} & 12 \\ 75^{\circ} 20^{\prime} / 21^{\circ} 00^{\prime} & 12 \\ 68^{\circ} 10^{\prime} / 52^{\circ} 28^{\prime} & 6 \\ 61^{\circ} 11^{\prime} / 48^{\circ} 26^{\prime} & 7 \\ 64^{\circ} 48^{\prime} / 52^{\circ} 12^{\prime} & 7 \\ 67^{\circ} 57^{\prime} / 53^{\circ} 38^{\prime} & 6\end{array}$
$73^{\circ} 00^{\prime} / 62^{\circ} 00^{\prime}$ $75^{\circ} 59^{\prime} / 21^{\circ} 00^{\prime}$ $78^{\circ} 08^{\prime} / 23^{\circ} 48^{\prime}$ $62^{\circ} 55^{\prime} / 50^{\circ} 10^{\prime}$ $60^{\circ} 55^{\prime} / 46^{\circ} 25^{\prime}$ $64^{\circ} 25^{\prime} / 23^{\circ} 00^{\prime}$ $71^{\circ} 40^{\prime} / 22^{\circ} 15^{\prime}$ $76^{\circ} 43^{\prime} / 72^{\circ} 58^{\prime}$ $71^{\circ} 53^{\prime} / 29^{\circ} 45^{\prime}$ $68^{\circ} 49^{\prime} / 51^{\circ} 11^{\prime}$ $74^{\circ} 18^{\prime} / 21^{\circ} 00^{\prime}$ $70^{\circ} 45^{\prime} / 22^{\circ} 36^{\prime}$

$\begin{array}{lr}74^{\circ} 19^{\prime} / 20^{\circ} 14^{\prime} & 12 \\ 60^{\circ} 53^{\prime} / 43^{\circ} 08^{\prime} & 10 \\ 81^{\circ} 10^{\prime} / 21^{\circ} 30^{\prime} & 11 \\ 66^{\circ} 10^{\prime} / 27^{\circ} 00^{\prime} & 12,13 \\ 76^{\circ} 46^{\prime} / 18^{\circ} 39^{\prime} & 11 \\ 68^{\circ} 00^{\prime} / 57^{\circ} 00^{\prime} & 6 \\ 69^{\circ} 45^{\prime} / 53^{\circ} 30^{\prime} & 6 \\ 69^{\circ} 11^{\prime} / 52^{\circ} 45^{\prime} & 6 \\ 72^{\circ} 35^{\prime} / 37^{\circ} 38^{\prime} & 9\end{array}$

$79^{\circ} 13^{\prime} / 76^{\circ} 50^{\prime}$ $68^{\circ} 49^{\prime} / 26^{\circ} 00^{\prime}$

$77^{\circ} 11^{\prime} / 61^{\circ} 07^{\prime}$
Place name

Lat. / Long. Map N W segment

Dove Bugt

Dronning Louise Land

Dye 3

$76^{\circ} 37^{\prime} / 20^{\circ} 00^{\prime} \quad 11$

$76^{\circ} 30^{\prime} / 24^{\circ} 30^{\prime} \quad 11$

$65^{\circ} 11^{\prime} / 43^{\circ} 50^{\prime} \quad 10$

\section{E}

Egedesminde

$68^{\circ} 43^{\prime} / 52^{\circ} 53^{\prime} \quad 6$

Eleonore Bugt

Ella $\varnothing$

Ellesmere Island (Canada)

$73^{\circ} 26^{\prime} / 25^{\circ} 23^{\prime} \quad 12$

$72^{\circ} 55^{\prime} / 25^{\circ} 05^{\prime} \quad 12$

$80^{\circ} 00^{\prime} / 80^{\circ} 00^{\prime} \quad 5$

F

Fiskefjord

Fiskenæsset

Frederick E. Hyde Fjord

Frederikshåb

Frederikshåb Isblink

Freuchen Land

$64^{\circ} 54^{\prime} / 51^{\circ} 33^{\prime} \quad 7$

$63^{\circ} 05^{\prime} / 50^{\circ} 41^{\prime} \quad 7$

$83^{\circ} 10^{\prime} / 30^{\circ} 30^{\prime} \quad 8$

$62^{\circ} 00^{\prime} / 49^{\circ} 40^{\prime} \quad 7$

$62^{\circ} 35^{\prime} / 49^{\circ} 55^{\prime} \quad 7$

$82^{\circ} 20^{\prime} / 43^{\circ} 30^{\prime} \quad 8$

$70^{\circ} 04^{\prime} / 28^{\circ} 00^{\prime} \quad 12$

$69^{\circ} 56^{\prime} / 25^{\circ} 30^{\prime} \quad 12$

$77^{\circ} 06^{\prime} / 18^{\circ} 55^{\prime} \quad 11$

$73^{\circ} 36^{\prime} / 55^{\circ} 58^{\prime} \quad 6$

$72^{\circ} 35^{\prime} / 38^{\circ} 27^{\prime} \quad 9$

$72^{\circ} 40^{\prime} / 27^{\circ} 00^{\prime} \quad 12$

$69^{\circ} 15^{\prime} / 53^{\circ} 33^{\prime} \quad 6$

$64^{\circ} 11^{\prime} / 51^{\circ} 45^{\prime} \quad 7$

$64^{\circ} 25^{\prime} / 51^{\circ} 25^{\prime} \quad 7$

$61^{\circ} 23^{\prime} / 47^{\circ} 53^{\prime} \quad 7$

$80^{\circ} 24^{\prime} / 83^{\circ} 00^{\prime} \quad 5$

$77^{\circ} 00^{\prime} / 10^{\circ} 00^{\prime} \quad 11$

$61^{\circ} 14^{\prime} / 48^{\circ} 06^{\prime} \quad 7$

$68^{\circ} 51^{\prime} / 29^{\circ} 52^{\prime} \quad 12$

H

Hagen Fjord

Hall Bassin

Hall Bredning

Hall Land

Hans $\varnothing$

Hans Tausen Iskappe

Hareøen

Hellefisk-1

Herluf Trolle Land $81^{\circ} 35^{\prime} / 25^{\circ} 30^{\prime} \quad 8$

$81^{\circ} 30^{\prime} / 63^{\circ} 00^{\prime} \quad 5$

$70^{\circ} 54^{\prime} / 24^{\circ} 45^{\prime} \quad 12$

$81^{\circ} 30^{\prime} / 60^{\circ} 00^{\prime} \quad 5$

$80^{\circ} 50^{\prime} / 66^{\circ} 38^{\prime} \quad 5$

$82^{\circ} 32^{\prime} / 38^{\circ} 00^{\prime} \quad 8$

$70^{\circ} 26^{\prime} / 54^{\circ} 55^{\prime} \quad 6$

$67^{\circ} 52^{\prime} / 56^{\circ} 44^{\prime} \quad 6$

$82^{\circ} 30^{\prime} / 26^{\circ} 30^{\prime} \quad 8$ 
Place name

Lat. / Long. Map N W segment

Hochstetter Forland

Hold with Hope

Holm Land

[Holm Ø] see Kiatassuaq

Holsteinsborg

Hovgaard Ø

Hudson Land

Humboldt Gletscher

\section{I}

Ikaasakajik

Ikeq

[Ikerasassuaq] see Prins Christian Sund

Ikermiut-1

Ikersuaq

Ikertivaq

Île de France

Ilimananngip Nunaa

Illoqqortoormiut

Illorsuit

[Iluileq] see Danell Fjord

Ilulissat

Independence Fjord

Inglefield Land

Ingolf Fjord

Innaanganeq

Inuit Qeqertaat

Ísafjörður (Iceland)

Island (Iceland)

Isukasia

Ittertivaa

Ivisaartoq

Ivittuut

\section{J}

Jakobshavn

Jakobshavn Isfjord

Jameson Land

J.C. Christensen Land

Johannes V. Jensen Land

Jøkelbugten

J.P. Koch Fjord

Julianehåb

\section{K}

Kaffeklubben $\varnothing$

Kane Bassin

Kangaamiut

Kangaarsugsuaq

Kangaatsiaq

Kangâmiut-1

Kangeq

Kangerlussuaq (East Greenland)

Kangerlussuaq (West Greenland)

$\begin{array}{lr}75^{\circ} 30^{\prime} / 19^{\circ} 53^{\prime} & 12 \\ 73^{\circ} 44^{\prime} / 21^{\circ} 10^{\prime} & 12 \\ 80^{\circ} 26^{\prime} / 17^{\circ} 30^{\prime} & 11 \\ & \\ 66^{\circ} 56^{\prime} / 53^{\circ} 40^{\prime} & 6 \\ 79^{\circ} 55^{\prime} / 18^{\circ} 30^{\prime} & 11 \\ 73^{\circ} 49^{\prime} / 23^{\circ} 00^{\prime} & 12 \\ 79^{\circ} 30^{\prime} / 63^{\circ} 30^{\prime} & 5\end{array}$

$70^{\circ} 55^{\prime} / 27^{\circ} 00^{\prime}$ $64^{\circ} 56^{\prime} / 40^{\circ} 35^{\prime}$

12 10

$66^{\circ} 56^{\prime} / 56^{\circ} 35^{\prime}$

$60^{\circ} 55^{\prime} / 46^{\circ} 25^{\prime}$

$65^{\circ} 29^{\prime} / 39^{\circ} 35^{\prime}$

$77^{\circ} 49^{\prime} / 17^{\circ} 50^{\prime}$

$70^{\circ} 43^{\prime} / 26^{\circ} 48^{\prime}$

$70^{\circ} 29^{\prime} / 21^{\circ} 58^{\prime}$

$71^{\circ} 09^{\prime} / 53^{\circ} 40^{\prime}$

$69^{\circ} 13^{\prime} / 51^{\circ} 07^{\prime}$

$82^{\circ} 05^{\prime} / 29^{\circ} 30^{\prime}$

$78^{\circ} 44^{\prime} / 69^{\circ} 00^{\prime}$

$80^{\circ} 30^{\prime} / 18^{\circ} 00^{\prime}$

$75^{\circ} 55^{\prime} / 66^{\circ} 28^{\prime}$

$83^{\circ} 40^{\prime} / 30^{\circ} 35^{\prime}$

$66^{\circ} 05^{\prime} / 23^{\circ} 10^{\prime}$

$65^{\circ} 00^{\prime} / 18^{\circ} 00^{\prime}$

$65^{\circ} 11^{\prime} / 49^{\circ} 48^{\prime}$

$69^{\circ} 25^{\prime} / 24^{\circ} 06^{\prime}$

$64^{\circ} 49^{\prime} / 49^{\circ} 58^{\prime}$

$61^{\circ} 12^{\prime} / 48^{\circ} 10^{\prime}$

$69^{\circ} 13^{\prime} / 51^{\circ} 07^{\prime}$

$71^{\circ} 10^{\prime} / 23^{\circ} 15^{\prime}$

$81^{\circ} 40^{\prime} / 29^{\circ} 30^{\prime}$

$83^{\circ} 20^{\prime} / 32^{\circ} 00^{\prime}$

$78^{\circ} 38^{\prime} / 20^{\circ} 00^{\prime}$

$82^{\circ} 45^{\prime} / 44^{\circ} 30^{\prime}$

$60^{\circ} 43^{\prime} / 46^{\circ} 03^{\prime}$

$83^{\circ} 40^{\prime} / 30^{\circ} 35^{\prime}$

$79^{\circ} 30^{\prime} / 69^{\circ} 00^{\prime}$

$65^{\circ} 50^{\prime} / 53^{\circ} 21^{\prime}$

$77^{\circ} 01^{\prime} / 71^{\circ} 23^{\prime}$

$68^{\circ} 19^{\prime} / 53^{\circ} 28^{\prime}$

$66^{\circ} 09^{\prime} / 56^{\circ} 11^{\prime}$

$61^{\circ} 50^{\prime} / 42^{\circ} 06^{\prime}$

$68^{\circ} 22^{\prime} / 32^{\circ} 12^{\prime}$

$66^{\circ} 24^{\prime} / 52^{\circ} 30^{\prime}$ $69^{\circ} 10^{\prime} / 50^{\circ} 30^{\prime}$
Place name

Lat. / Long. Map N W segment

[Kangerlussuatsiaq] see Lindenow Fjord

Kangersik Kiatteq

Kangersuatsiaq

Kangertittivaq

Kangertittivatsiaq

Kangikajik

Kap Alexander

Kap Brewster

Kap Bryant

Kap Cort Adelaer

Kap Dalton

Kap Edvard Holm

Kap Eiler Rasmussen

Kap Farvel

Kap Franklin

Kap Gustav Holm

Kap København

Kap Morris Jesup

Kap Møsting

Kap Parry

Kap Ravn

Kap Tordenskjold

Kap Washington

Kap York

Karrat Isfjord

Keflavik (Iceland)

Kejser Franz Joseph Fjord

Kennedy Kanal

Kialiip Imaa

Kiatassuaq [Holm Ø]

Kilen

Kitsissut

Kobberminebugt

Køge Bugt

Kong Oscar Fjord

Kronprins Christian Land

Kuhn $\varnothing$

Kullorsuaq

Kulusuk

Kuummiut

$71^{\circ} 30^{\prime} / 26^{\circ} 00^{\prime}$

$72^{\circ} 23^{\prime} / 55^{\circ} 34^{\prime} \quad 6$

$70^{\circ} 17^{\prime} / 23^{\circ} 00^{\prime} \quad 12$

$66^{\circ} 21^{\prime} / 35^{\circ} 43^{\prime} \quad 10$

$70^{\circ} 09^{\prime} / 22^{\circ} 03^{\prime} \quad 12$

$78^{\circ} 11^{\prime} / 73^{\circ} 02^{\prime} \quad 5$

$70^{\circ} 09^{\prime} / 22^{\circ} 03^{\prime} \quad 12$

$82^{\circ} 20^{\prime} / 55^{\circ} 15^{\prime} \quad 8$

$61^{\circ} 50^{\prime} / 42^{\circ} 06^{\prime} \quad 10$

$69^{\circ} 25^{\prime} / 24^{\circ} 06^{\prime} \quad 12$

$67^{\circ} 51^{\prime} / 32^{\circ} 11^{\prime} \quad 9$

$82^{\circ} 35^{\prime} / 19^{\circ} 45^{\prime} \quad 8$

$59^{\circ} 47^{\prime} / 43^{\circ} 55^{\prime} \quad 10$

$73^{\circ} 15^{\prime} / 22^{\circ} 10^{\prime} \quad 12$

$66^{\circ} 34^{\prime} / 34^{\circ} 20^{\prime} \quad 10$

$82^{\circ} 23^{\prime} / 20^{\circ} 57^{\prime} \quad 8$

$83^{\circ} 39^{\prime} / 33^{\circ} 25^{\prime} \quad 8$

$63^{\circ} 41^{\prime} / 40^{\circ} 31^{\prime} \quad 10$

$77^{\circ} 01^{\prime} / 71^{\circ} 23^{\prime} \quad 5$

$68^{\circ} 26^{\prime} / 28^{\circ} 16^{\prime} \quad 12$

$61^{\circ} 24^{\prime} / 42^{\circ} 23^{\prime} \quad 10$

$83^{\circ} 33^{\prime} / 38^{\circ} 40^{\prime} \quad 8$

$75^{\circ} 55^{\prime} / 66^{\circ} 28^{\prime} \quad 5$

$71^{\circ} 34^{\prime} / 52^{\circ} 25^{\prime} \quad 6$

$64^{\circ} 00^{\prime} / 22^{\circ} 30^{\prime} \quad 13$

$73^{\circ} 21^{\prime} / 23^{\circ} 30^{\prime} \quad 12$

$80^{\circ} 40^{\prime} / 68^{\circ} 00^{\prime} \quad 5$

$66^{\circ} 55^{\prime} / 33^{\circ} 45^{\prime} \quad 10$

$74^{\circ} 30^{\prime} / 57^{\circ} 00^{\prime} \quad 6$

$81^{\circ} 11^{\prime} / 13^{\circ} 25^{\prime} \quad 11$

$76^{\circ} 43^{\prime} / 72^{\circ} 58^{\prime} \quad 5$

$60^{\circ} 55^{\prime} / 48^{\circ} 17^{\prime} \quad 7$

$64^{\circ} 56^{\prime} / 40^{\circ} 35^{\prime} \quad 10$

$72^{\circ} 22^{\prime} / 24^{\circ} 00^{\prime} \quad 12$

$80^{\circ} 40^{\prime} / 21^{\circ} 00^{\prime} \quad 11$

$74^{\circ} 50^{\prime} / 20^{\circ} 20^{\prime} \quad 12$

$74^{\circ} 34^{\prime} / 57^{\circ} 10^{\prime} \quad 6$

$65^{\circ} 34^{\prime} / 37^{\circ} 11^{\prime} \quad 10$

$65^{\circ} 52^{\prime} / 37^{\circ} 01^{\prime} \quad 10$

\section{L}

Lake Hazen (Canada)

Lambert Land

Lauge Koch Kyst

Lincoln Hav

Lindenow Fjord [Kangerlussuatsiaq]

Liverpool Land

Lyell Land

[Lysefjord] see Ameralik

$81^{\circ} 47^{\prime} / 70^{\circ} 50^{\prime} \quad 5$

$79^{\circ} 19^{\prime} / 20^{\circ} 48^{\prime} \quad 11$

$76^{\circ} 20^{\prime} / 60^{\circ} 00^{\prime} \quad 5$

$83^{\circ} 25^{\prime} / 57^{\circ} 00^{\prime} \quad 8$

$60^{\circ} 30^{\prime} / 43^{\circ} 30^{\prime} \quad 10$

$70^{\circ} 55^{\prime} / 22^{\circ} 00^{\prime} \quad 12$

$72^{\circ} 38^{\prime} / 25^{\circ} 35^{\prime} \quad 12$

\section{M}

Maarmorilik

Mallemukfjeld $71^{\circ} 08^{\prime} / 51^{\circ} 18^{\prime} \quad 6$

$80^{\circ} 10^{\prime} / 17^{\circ} 04^{\prime} \quad 11$ 
Maniitsoq

Melville Bugt

Mestersvig

Midternæs

Milne Land

Mont Forel

Mylius-Erichsen Land

\section{$\mathbf{N}$}

Nakkehoved

Nanortalik

Nansen Fjord

Nansen Land

Nansen Sound (Canada)

Nares Stræde

Narsaq

Narsarsuaq

Nassuttooq

Neriap Nunaa

Nertiit Kangersivat

Niaqornaarsuk

Niaqorsuaq

Nioghalvfjerdsfjorden

Nordatlanten

Nordlandet

Nordostrundingen

Nordre Strømfjord

Nordvestfjord

Norske Øer

Nukik-1

Nukik-2

Nunakuluut [Nunarssuit]

Nunap Isua

[Nunarssuit] see Nunakuluut

Nuuk

Nuup Kangerlua

Nuussuaq

Nyeboe Land

Øfjord

\section{$\mathbf{P}$}

Paamiut

Peary Land

Petermann Bjerg

Petermann Gletscher

Pituffik

Prins Christian Sund [Ikerasassuaq] Prinsen af Wales Bjerge

Prøven

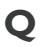

Qaanaaq

$\begin{array}{lr}65^{\circ} 25^{\prime} / 52^{\circ} 52^{\prime} & 7 \\ 75^{\circ} 45^{\prime} / 60^{\circ} 50^{\prime} & 5 \\ 72^{\circ} 14^{\prime} / 23^{\circ} 55^{\prime} & 12 \\ 61^{\circ} 37^{\prime} / 47^{\circ} 56^{\prime} & 7 \\ 70^{\circ} 43^{\prime} / 26^{\circ} 48^{\prime} & 12 \\ 66^{\circ} 56^{\prime} / 36^{\circ} 49^{\prime} & 10 \\ 81^{\circ} 00^{\prime} / 26^{\circ} 00^{\prime} & 8\end{array}$
$60^{\circ} 09^{\prime} / 45^{\circ} 15^{\prime}$ $68^{\circ} 17^{\prime} / 29^{\circ} 50^{\prime}$ $82^{\circ} 56^{\prime} / 44^{\circ} 20^{\prime}$ $81^{\circ} 00^{\prime} / 90^{\circ} 00^{\prime}$ $80^{\circ} 00^{\prime} / 69^{\circ} 00^{\prime}$ $60^{\circ} 55^{\prime} / 46^{\circ} 03^{\prime}$ $61^{\circ} 10^{\prime} / 45^{\circ} 25^{\prime}$ $67^{\circ} 45^{\prime} / 53^{\circ} 00^{\prime \prime}$ $61^{\circ} 23^{\prime} / 47^{\circ} 53^{\prime}$ $70^{\circ} 04^{\prime} / 28^{\circ} 00^{\prime \prime}$ $68^{\circ} 14^{\prime} / 52^{\circ} 52^{\prime}$ $75^{\circ} 04^{\prime} / 58^{\circ} 05^{\prime}$ $79^{\circ} 34^{\prime} / 21^{\circ} 00^{\prime \prime}$ $62^{\circ} 00^{\prime} / 29^{\circ} 00^{\prime \prime}$ $64^{\circ} 24^{\prime} / 51^{\circ} 43^{\prime}$ $81^{\circ} 21^{\prime} / 11^{\circ} 20^{\prime}$ $67^{\circ} 45^{\prime} / 53^{\circ} 00^{\prime}$

$71^{\circ} 30^{\prime} / 26^{\circ} 00^{\prime \prime}$ $79^{\circ} 07^{\prime} / 17^{\circ} 50^{\prime \prime}$ $65^{\circ} 31^{\prime} / 54^{\circ} 45^{\prime}$ $65^{\circ} 38^{\prime} / 54^{\circ} 46^{\prime}$ $60^{\circ} 46^{\prime} / 47^{\circ} 57^{\prime}$ $59^{\circ} 47^{\prime} / 43^{\circ} 55^{\prime \prime}$

$64^{\circ} 11^{\prime} / 51^{\circ} 45^{\prime}$ $64^{\circ} 25 / 51^{\circ} 25^{\prime}$ $70^{\circ} 35^{\prime} / 52^{\circ} 55^{\prime}$ $81^{\circ} 45^{\prime} / 57^{\circ} 00^{\prime}$

$70^{\circ} 55^{\prime} / 27^{\circ} 00^{\prime}$ 12

$62^{\circ} 00^{\prime} / 49^{\circ} 40^{\prime}$ $82^{\circ} 35^{\prime} / 31^{\circ} 00^{\prime}$ $73^{\circ} 05^{\prime} / 28^{\circ} 37^{\prime}$ $80^{\circ} 35^{\prime} / 59^{\circ} 35^{\prime}$ $76^{\circ} 33^{\prime} / 68^{\circ} 15^{\prime}$ $60^{\circ} 07^{\prime} / 43^{\circ} 30^{\prime}$ $68^{\circ} 56^{\prime} / 32^{\circ} 30^{\prime}$ $72^{\circ} 23^{\prime} / 55^{\circ} 34^{\prime}$

$77^{\circ} 28^{\prime} / 69^{\circ} 14^{\prime}$

Place name

Lat. / Long. Map $\mathrm{N}$ W segment

Qaqortoq

Qasigiannguit

Qeqertarsuaq (Disko)

Qeqertarsuaq (Godhavn)

Qeqertarsuatsiaat

Qeqertarsuatsiaq

Qeqertarsuup Tunua

Qimusseriarsuaq

Qullissat

Qunaranaaq

\section{$\mathbf{R}$}

Ravn Storø

Red Head

Renland

Reykjavik (Iceland)

Rink Isbræ

Robeson Kanal

\section{$\mathbf{S}$}

Saqqisikuik

Sarfartoq

Scoresby Land

Scoresby Sund

Scoresbysund

Sermersuaq (Humboldt Gletscher)

Sermersuaq (Steenstrup Gletscher)

Sermiligaarsuk

Sermilik

Shannon

Sherard Osborn Fjord

Sisimiut

Skærfjorden

Skærgårdshalvø

Skjoldungen

Skrækkens Bugt

Smith Sund

Snæfellsnes (Iceland)

Søndre Strømfjord (airport)

Søndre Strømfjord (fjord)

Station Nord

Stauning Alper

Steenstrup Gletscher

Store Koldewey

Storstrømmen

Suess Land

Sukkertoppen

Sullorsuaq

Svartenhuk Halvø

Sydprøven

\section{T}

Taartoq

Tasiilap Karra $60^{\circ} 43^{\prime} / 46^{\circ} 03^{\prime} \quad 7$

$68^{\circ} 49^{\prime} / 51^{\circ} 11^{\prime} \quad 6$

$69^{\circ} 45^{\prime} / 53^{\circ} 30^{\prime} \quad 6$

$69^{\circ} 15^{\prime} / 53^{\circ} 33^{\prime} \quad 6$

$63^{\circ} 05^{\prime} / 50^{\circ} 41^{\prime} \quad 7$

$70^{\circ} 26^{\prime} / 54^{\circ} 55^{\prime} \quad 6$

$69^{\circ} 11^{\prime} / 52^{\circ} 45^{\prime} \quad 6$

$75^{\circ} 45^{\prime} / 60^{\circ} 50^{\prime} \quad 5$

$70^{\circ} 05^{\prime} / 53^{\circ} 01^{\prime} \quad 6$

$61^{\circ} 24^{\prime} / 42^{\circ} 23^{\prime} \quad 10$

$62^{\circ} 43^{\prime} / 50^{\circ} 23^{\prime} 7$

$75^{\circ} 04^{\prime} / 58^{\circ} 05^{\prime} \quad 6$

$71^{\circ} 20^{\prime} / 26^{\circ} 45^{\prime} \quad 12$

$64^{\circ} 10^{\prime} / 22^{\circ} 00^{\prime} \quad 13$

$71^{\circ} 47^{\prime} / 51^{\circ} 23^{\prime} \quad 6$

$81^{\circ} 53^{\prime} / 62^{\circ} 00^{\prime}$

$63^{\circ} 22^{\prime} / 41^{\circ} 35^{\prime} \quad 10$

$66^{\circ} 25^{\prime} / 51^{\circ} 23^{\prime} 7$

$71^{\circ} 45^{\prime} / 25^{\circ} 00^{\prime} \quad 12$

$70^{\circ} 17^{\prime} / 23^{\circ} 00^{\prime} \quad 12$

$70^{\circ} 29^{\prime} / 21^{\circ} 58^{\prime} \quad 12$

$79^{\circ} 30^{\prime} / 63^{\circ} 30^{\prime} \quad 5$

$75^{\circ} 17^{\prime} / 57^{\circ} 53^{\prime} \quad 6$

$61^{\circ} 30^{\prime} / 48^{\circ} 40^{\prime}$

$66^{\circ} 11^{\prime} / 37^{\circ} 36^{\prime} \quad 10$

$75^{\circ} 08^{\prime} / 18^{\circ} 15^{\prime} \quad 12$

$82^{\circ} 05^{\prime} / 52^{\circ} 05^{\prime} \quad 8$

$66^{\circ} 56^{\prime} / 53^{\circ} 40^{\prime} \quad 6$

$77^{\circ} 30^{\prime} / 19^{\circ} 30^{\prime} \quad 11$

$68^{\circ} 09^{\prime} / 31^{\circ} 45^{\prime} \quad 12$

$63^{\circ} 22^{\prime} / 41^{\circ} 35^{\prime} \quad 10$

$66^{\circ} 55^{\prime} / 33^{\circ} 45^{\prime} \quad 10$

$78^{\circ} 30^{\prime} / 74^{\circ} 00^{\prime} \quad 5$

$64^{\circ} 50^{\prime} / 23^{\circ} 37^{\prime} \quad 13$

$66^{\circ} 58^{\prime} / 50^{\circ} 57^{\prime} \quad 6$

$66^{\circ} 24^{\prime} / 52^{\circ} 30^{\prime} \quad 7$

$81^{\circ} 35^{\prime} / 16^{\circ} 41^{\prime} \quad 11$

$72^{\circ} 00^{\prime} / 25^{\circ} 00^{\prime} \quad 12$

$75^{\circ} 17^{\prime} / 57^{\circ} 53^{\prime} \quad 6$

$76^{\circ} 30^{\prime} / 19^{\circ} 00^{\prime} \quad 11$

$76^{\circ} 53^{\prime} / 22^{\circ} 50^{\prime} \quad 11$

$72^{\circ} 58^{\prime} / 25^{\circ} 35^{\prime} \quad 12$

$65^{\circ} 25^{\prime} / 52^{\circ} 52^{\prime} \quad 7$

$70^{\circ} 16^{\prime} / 53^{\circ} 25^{\prime}$

$71^{\circ} 45^{\prime} / 54^{\circ} 50^{\prime} \quad 6$

$60^{\circ} 28^{\prime} / 45^{\circ} 34^{\prime}$

$61^{\circ} 25^{\prime} / 48^{\circ} 50^{\prime} \quad 7$

$66^{\circ} 34^{\prime} / 34^{\circ} 20^{\prime} \quad 10$ 


\begin{tabular}{|c|c|}
\hline Place name & Lat. / Long. \\
\hline & N W \\
\hline
\end{tabular}

\section{Tasiilaq}

Thule

Thule Air Base

Traill $\varnothing$

Tuttut Nunat

\section{U}

Ubekendt Ejland

Ullersuaq

Umiivik

United States Range (Canada)

Upernavik

Upernavik Isfjord

Ussing Isfjord

Uummannaq

\section{v}

Vaigat

Victoria Fjord $65^{\circ} 36^{\prime} / 37^{\circ} 38^{\prime}$

$77^{\circ} 28^{\prime} / 69^{\circ} 14^{\prime}$

$76^{\circ} 33^{\prime} / 68^{\circ} 15^{\prime}$

$72^{\circ} 40^{\prime} / 23^{\circ} 43^{\prime}$

$71^{\circ} 20^{\prime} / 26^{\circ} 45^{\prime}$

$71^{\circ} 09^{\prime} / 53^{\circ} 40^{\prime}$ $78^{\circ} 11^{\prime} / 73^{\circ} 02^{\prime}$

$82^{\circ} 00^{\prime} / 72^{\circ} 00^{\prime}$

$72^{\circ} 47^{\prime} / 56^{\circ} 10^{\prime}$

$72^{\circ} 55^{\prime} / 55^{\circ} 30^{\prime}$

$73^{\circ} 54^{\prime} / 56^{\circ} 00^{\prime}$

$70^{\circ} 41^{\prime} / 52^{\circ} 08^{\prime}$

$70^{\circ} 16^{\prime} / 53^{\circ} 25^{\prime}$

$82^{\circ} 09^{\prime} / 47^{\circ} 45^{\prime}$ $64^{\circ} 16^{\prime} / 40^{\circ} 35^{\prime}$
Place name

Lat. / Long.

Map

N W segment

\section{W}

Waltershausen Gletscher

$74^{\circ} 09^{\prime} / 25^{\circ} 30^{\prime}$

$82^{\circ} 14^{\prime} / 33^{\circ} 30^{\prime}$

$82^{\circ} 30^{\prime} / 12^{\circ} 00^{\prime}$

$83^{\circ} 08^{\prime} / 75^{\circ} 00^{\prime}$

$81^{\circ} 34^{\prime} / 52^{\circ} 50^{\prime}$

$80^{\circ} 30^{\prime} / 64^{\circ} 00^{\prime}$

$68^{\circ} 51^{\prime} / 29^{\circ} 30^{\prime}$

$74^{\circ} 26^{\prime} / 19^{\circ} 35^{\prime}$

$81^{\circ} 51^{\prime} / 48^{\circ} 30^{\prime}$

$73^{\circ} 11^{\prime} / 24^{\circ} 30^{\prime}$

12

Ymer $\varnothing$

$70^{\circ} 55^{\prime} / 27^{\circ} 00^{\prime}$

12

12

8

11

8

5

12

12

8

Øfjord 


\section{Index}

In the listing the Danish letters Æ, $\varnothing$ and $\AA$ are treated as $\mathrm{AE}, \mathrm{O}$ and $\mathrm{A}$. For the use of the geographical subdivisions see the map on page 4 .

Page numbers in bold refer to figures.

\author{
Abbreviations \\ Fm Formation \\ Gp Group \\ SGp Supergroup \\ cEG central East Greenland \\ cNG central North Greenland \\ cWG central West Greenland \\ EG East Greenland (includes cEG, NEG, sEG, SEG) \\ eNG eastern North Greenland \\ NEG North-East Greenland \\ NG North Greenland \\ NWG North-West Greenland \\ sEG southern East Greenland \\ SEG South-East Greenland \\ SG South Greenland \\ sWG southern West Greenland \\ SWG South-West Greenland \\ WG West Greenland (includes cWG, NWG, sWG, SWG) \\ wNG western North Greenland
}

\section{A}

Aasiaat domain 23

Aasiat Basin: cWG 15

Aasiat Structural Trend: cWG 89

Aasivik terran: sWG 19

Accretion of Precambrian crustal blocks: sWG 15, 21, 48

Aeromagnetic data 24, 66, 67

Agatdal Formation (Paleocene): cWG 57, 58, 59

Agpaitic rocks, see Alkaline rocks

Akia terrane (Mesoarchaean): sWG 19

Akilia association (Eoarchaean): sWG 18

Albian: NEG, cWG, SEG, sWG 56, 58, 60, 75

Albian-Campanian (Cretaceous): cWG 57

Alkali acid rocks (Gardar): SG 35

Alkaline rocks: EG, SG 62,82

Ameralik dykes (Eoarchaean): sWG 18, 18, 36

Amikoq: sWG 79

Amitsoq: SG 79

Amîtsoq gneiss (Eoarchaean): sWG 18, 36, 37

Amîtsoq iron-rich suite (Eoarchaean): sWG 18

Ammassalik Intrusive Complex (Palaeoproterozoic): SEG 24

Ammassalik mobile belt (Palaeoproterozoic): sEG, SEG 24

Amundsen Land Gp (Ordovician): NG 46, 46, 48, 78

Anap nunâ Gp (Palaeoproterozoic): cWG 26

Andrée Land Gp (Neoproterozoic): cEG, NEG 42, 43

Anorthositic rocks

cWG (Mesoarchaean) 26
NEG (Proterozoic), see Legend explanation [86] 112

NWG (Neoarchaean) 27

SEG (Nagssugtoqidian orogen) 24

sWG (Mesoarchaean) 16, 19, 80

Antiklinalbugt Fm (Ordovician): NEG 50

Antimony (Sb): NEG 79

Appat sequence (Cretaceous): sWG 75, 76, 76, 89

Appinites (Proterozoic): SG, SEG 29, 37

Aptian-Albian (Cretaceous)

NEG 56

sEG 60

Archaean

Eoarchaean craton: sWG 16, 17, 18, 36

craton: SEG, sWG, SWG 14, 14, 15, 16, 17, 19-22, 21, 28, 36, $44,79,80$

gneisses (Meso-Neoarchaean): sWG, SEG 19, 21

intrusive rocks (Meso-Neoarchaean): SEG, sWG 20, 21

mineral deposits 80,81

reworked rocks 14,14

cEG, NEG 31

sEG, SEG, WG 21-28, 23, 25

supracrustal rocks

Eoarchaean: sWG 17

Meso-Neoarchaean

cWG 23

SEG, sWG, SWG 19,24

terrane boundaries $16,17,19-21$

Archaean basement beneath the Inland Ice 32

Archaean orogenesis 15-20

Archaean terraines 14

ARCO 86

Arfersiorfik quartz diorite: sWG 23, 24

Arveprinsens Ejland: cWG 79

Asphalt residues 84

Atâ igneous complex 26

Ataata Kuua: cWG 59

Atammik: sWG 22

Atane Fm (Cretaceous): cWG 57, 58

Atanikerdluk Fm (Paleocene): cWG 58

Atlantic Richfield Company 86

Attu: sWG 79

Augite syenite (Gardar): SG 35

B

Bache Peninsula (Canada) 69, 72

Baffin Bay Gp (Meso-Neoproterozoic): NWG 40, 40

Baffin Bay (Bugt): NWG 71, 85, 90

Baffin Island (Canada) 71 
Baltica 50

Banded iron formation

Isua supracrustal sequences: $s W G \quad 17,17,80$

cWG 26

NWG 27, 81

Barden Bugt Fm (Meso-Neoproterozoic): NWG 40

Barite: NG, cEG 79

Barremian-Albian (Cretaceous), offshore: sWG 75

Basalts

Archaean 19

Paleocene: cNG 53, 54

Palaeoproterozoic: SWG 28

Meso-Neoproterozoic: NG, SG, NWG 33, 35, 37, 39

Palaeogene 79, 85

cWG $37,58,59,60,89,90$

EG $37,60,61,61,62$

Tertiary offshore $67-69,74,76,76,85$

Base metals, exploration 9, 78

Basement provinces 9, 14, 14

Basic dykes, see Dykes and sills

Basins, see Sedimentary basins

Bastion Fm (Cambrian): NEG 50

Batbjerg complex (Caledonian): sEG 51

Bathymetry 13

Bernbjerg Fm (Jurassic): NEG 56

Beryllium, prospect / deposit: SG 79, 82

BGR (Bundesanstalt für Geowiss. und Rohstoffe) 71

Bitumen 90

Bjørnesund block: sWG 16

Black Angel (Sorte Engel) lead-zinc deposit: cWG 26, 79, 81

Blosseville Gp (Cretaceous-Palaeogene): sEG 60

Blosseville Kyst Basin: cEG, sEG 75

petroleum potential 88

Blyklippen lead-zinc deposit (Mestersvig): cEG 79, 83

Borgtinderne intrusion (Tertiary): sEG 62

Bredehorn: cEG 79

Brogetdal: NEG 79

Brønlund Fjord Gp (Cambrian): NG 41, 46

Buen Fm (Cambrian): NG 41, 45, 46, 49

Bundesanstalt für Geowiss. und Rohstoffe (BGR) 71

\section{C}

Caledonides, East Greenland 50, 51

Archaean - Palaeoproterozoic basement: cEG, NEG 31, 31

sedimentary rocks of unknown age: NEG 43

fold belt units: cEG, eNG, NEG 51

reworked Neoproterozoic units: cEG, NEG 38, 38, 39, 39

sedimentary successions (Neoproterozoic-Palaeozoic) 41-44, 43,

44,50

intrusions: cEG, NEG 51,52

orogeny: cEG, eNG, NEG 50, 51, 52

Cambrian

sediments: NG 28, 41, 45, 46, 48, 49

deep-water trough: NG 45, 46, 48

source rocks: NG 84

Cambrian-Ordovician sediments: NEG 43, 50, 50

Cambrian-Silurian sediments: NG, NWG 45, 46
Campanuladal Fm (Neoproterozoic): cNG, eNG 42

Cape Camperdown Fm (Mesoproterozoic): NWG 40

Cape Combermere Fm (Mesoproterozoic): NWG 40

Cape Dyer (Canada) 69

Cape Smith orogen (Canada) 15

Cape Weber Fm (Ordovician): NEG 50

Carbonatite complexes 44

Mesoarchaean: sWG 21

Gardar (Mesoproterozoic): SG 38

Neoproterozoic/Jurassic: sWG 44

Carboniferous sediments

cEG, NEG $53,53,55,55,86,87$

eNG $53,54,54,79,84,86$

NG $45,48,48$

Carboniferous-Permian salt formation, offshore: NEG 73

Celestite: cEG 79

Celsius Bjerg Gp (Devonian-Carboniferous): NEG 53, 53

Charcot Land supracrustal succession (Palaeoproterozoic): cEG 31

Charcot Land tectonic window: cEG 31

Charnockitic intrusive rocks

NWG (Prøven ignous complex) 27

SEG (Ammassalik Intrusive Complex) 24

Chromite mineralisation: sWG 80

Chromium: sWG 79, 80

Chron numbers (magnetochrons) $13,66,70$

Citronen Fjord: cNG 76, 78, 79, 80

Citronen Fjord lead-zinc deposit: cNG 80

Clarence Head Fm (Mesoproterozoic): NWG 40

Clavering Ø: NEG 79

Climate, past 63,65

Coal: cWG 79

Coal deposit (Cretaceous): cWG 57, 58, 60

Cobalt: cWG 79

Continental break up, Palaeogene 60, 62

Continental crust, offshore $66-73,68,74,75,75$

Continental margin

EG, NG $66-70,73$

WG 70-72

Continental shelf $11,63,71,86$

Continent-ocean boundary (COB) 66, 67

Continent-ocean transition zone 67

Copper: NWG, cWG, SG, SEG, NEG 79

Cretaceous, sediments 79

cEG $55,56,56$

cNG, eNG 48, 53, 54, 55

cWG $8,57,58,83,86$

NEG $55,56,57,74,74$

offshore

sWG, SWG $71,75,76,86,88-90$

sEG 60

NG, NWG 70, 77

Cryolite: SWG 78, 79, 80, 82

Danell Fjord: SEG 38

Danish Expeditions to East Greenland 11

Danmark Stræde (Denmark Strait): sEG 67 
Danmarks Geologiske Undersøgelse (DGU) 11

Danmarkshavn Basin: NEG 74, 84, 85, 87

Danmarkshavn Ridge: NEG 73, 74

Davis Stræde (Davis Strait): sWG 69, 71, 75, 85

Davis Strait High: sWG 69, 71, 75, 89

De Geer megashear 70

Deep drillings

Inland Ice 65

onshore: cWG 57, 85, 89

offshore

SEG $66,67,75$

sWG $66,68,71,84,87$

through Inland Ice 32

Denmark Strait Fracture Zone 67

Devon Dal: cEG 79

Devonian sediments

NEG $51,52,53,53,79$

cEG 55

wNG 45, 48, 49

offshore: NEG 73, 74, 87

Diamictites (Neoproterozoic)

Morænesø Fm: cNG 41, 41

Tillite Gp: NEG 41, 42, 43, 43, 51

Diamond: sWG 79

Diamond exploration: sWG 44, 78

'Diamond Province': sWG 44

Disko Bugt suture: cWG 15, 22

Disko Bugt: cWG 4, 14, 15, 85

Disko Gneiss Ridge: cWG 89

Disko High: cWG 89

Dolerite dykes, see Dykes and sills

Dolomite Point Fm (Cambrian): NEG 50

Dove Bugt: NEG 32

Drill holes

Inland Ice 32, 65

offshore: sWG 66, 68, 71, 84, 87

onshore: cWG 57, 85, 89

Dundas Gp (Meso-Neoproterozoic): NWG 40, 40

Dykes and sills

Ameralik (Palaeoarchaean) 18, 18, 36, 37

Archaean 18, 18, 36, 37

Gardar (Mesoproterozoic): SG 35, 37, 38

Kangâmiut (Palaeoproterozoic): sWG 22, 36, 37

'MD' (Palaeoproterozoic): sWG, SWG 37

Midsommersø (Mesoproterozoic): cNG, eNG 33, 34, 37, 40

Phanerozoic 37

Proterozoic 37

Tarssartôq (Palaeoarchaean): sWG 37

'TD' (Cretaceous): SG, SWG 37

Tertiary 37, 61, 62, 67

Umîvik (Palaeoproterozoic): sEG, SEG 37

\section{E}

East Greenland escarpment: cEG 75

Eclogite: NEG 32, 50

sWG 24

Eemian (Quaternary) 63, 65, 65
Eleonore Bay SGp (Neoproterozoic): cEG, NEG 39, 41, 42, 43, 44, 51,52

Eleonore Sø series (Palaeoproterozoic): NEG 43

Eleonore Sø window: NEG 31

Ella $\varnothing \mathrm{Fm}$ (Cambrian): NEG 50

Ellesmere Island (Canada) 4, 33, 39, 45-49, 48, 72, 73, 85, 90

Ellesmere-Devonian terrane (Canada) 15

Ellesmerian fold belt (Palaeozoic): NG 48, 49, 78, 85

Ellesmerian orogeny (Palaeozoic): NG 51

Eoarchaean 15

supracrustal rocks 17

gneisses $16,18,18$

Eocene oceanic crust 68

Eocene sediments

offshore

cEG $75,75,88$

cWG 76, 90

sWG 76, 76, 89

onshore:

sEG 62

eNG 55

Eocene triple junction 70

Eqalulik Formation (Paleocene): cWG 58, 59

Eqalussuit: $s$ WG 79

Eqi: cWG 79

Eriksfjord Fm (Gardar): SG 35, 38

Etah Gp (Palaeoproterozoic): NWG 28

Eurasia Basin 70

Eurekan Orogen 72, 73

Evaporites, onshore

Carboniferous-Permian: NEG 73

Permian: cEG 56

Ordovician: NG 45, 46

Neoproterozoic: NEG 42

Meso-Neoproterozoic: NWG 40

Evaporites, offshore: NEG 73

Exotic terrane, Ellesmere Island (Canada), see Pearya 48, 49

Exploration wells (hydrocarbon): WG 57, 66, 67, 71, 84, 87, 88, 88

$\mathbf{F}$

Færingehavn terrane: sWG 16,17

Færingehavn: sWG 16

Fiskefjord block: sWG 16

Fiskefjord: sWG 20, 36

Fiskenæsset: $s$ WG 79

Fiskenæsset complex (Mesoarchaean): sWG 19, 20, 80

Flammefjeld: sEG 79

Fleming Fjord Fm (Triassic): cEG 56

Foldvik Creek Gp (Permian): cEG 56

'Fossilik' (Ordovician): sWG, see Legend explanation [9] 110

Foxe fold belt (Canada) 27

Foyaite (Gardar): SG 35

Fracture zones, oceanic: EG, WG 66, 67, 69, 69, 70-72, 74, 76, 89,90

Fram Strait (Greenland-Svalbard) 69, 70

Franklinian Basin (Cambro-Silurian) NG, NWG 28, 41, 45, 46, 48, 49,51 
mineral deposits: NG 78, 79

petroleum potential: NG 84

Franz Joseph thrust sheet unit: NEG 51

Fylla fault complex: cWG 76

Fyns Sø Fm (Neoproterozoic): cNG, eNG 41, 42

\section{G}

Gakkel Ridge: eNG 69, 70, 73

Garbenschiefer: sWG 17

Gardar Province (Mesoproterozoic): SG 15, 16, 35 intrusive complexes $35,38,44$

sediments 38

sills and dykes 38

volcanics 38

mineral deposits $78,79,82$

Gas 84, 86-89

Gåsefjord: cEG 61

Gåseland window: cEG 43

Geochemical surveys 11, 20, 21, 78

Geodetic Institute (GI) 13

Geological Survey of Denmark (DGU) 11

Geological Survey of Denmark and Greenland (GEUS) 11

Geological Survey of Greenland (GGU) 11

Geophysical surveys 11,66

Gipsdalen Fm (Triassic): cEG 56

GISP 2 (drilling through the Inland Ice): NEG 14, 32

Glaciation

$$
\begin{aligned}
& \text { Neoproterozoic } \\
& \text { Morænesø Fm: cNG } 41 \\
& \text { Tillite Gp: NEG } 42
\end{aligned}
$$

Quaternary 63

Glaciers 12, 63, 64

Glaciology 64

Glaciomarine sediments (offshore) 67

Godthåb (Nuuk): sWG 14, 16, 18

Godthåbsfjord (Nuup Kangerlua): sWG 17, 18, 18-21, 36, 80

Godthåbsfjord-Ameralik belt: sWG 16

Gold 79

Gold deposits

Nalunaq: SG 78, 79, 81, 81

Nuup Kangerlua (Godthåbsfjord): cWG 80

Skaergaard: sEG $\quad 62,79,83$

Gold exploration 78

Gold occurrences (Disko Bugt): cWG 80

Grænseland: SW 28, 29

Granulite facies

NEG 32

NWG 27, 28

SEG 25

sEG 51

SG 30

WG $16,17,18,20,21,22,24$

Graphite: NWG, sWG, SG 18, 23, 60, 79

Gravimetric data 12,66

Greenland

geological map 10,85

size 13 ice-free land areas 13

Greenland Fracture Zone: NEG 74

Greenland Mineralisation Data Bank 80

Greenland Ridge: NEG 69, 69, 70

Greenland Sea (Grønlandshavet): NEG 85

Greenstone belts (Archaean)

Disko Bugt: cWG 26

Eoarchaean: sWG 18

Grenvillian: cEG, NEG 43, 51

GRO\#3 exploration well: cWG 58, 59, 86, 89

grønArctic Energy Inc. 86

Grønlandshavet (Greenland Sea): NEG 85

Grønnedal: SWG 79

\section{H}

Hagar Bjerg thrust sheet: NEG 38, 39, 51

Hagen Fjord Gp (Neoproterozoic): cNG, eNG 33, 35, 40, 41, 41, 42,51

Hagen Fjord: eNG 42

Hall Land: wNG 46

Hammer Dal: cWG 79

Harder Bjerg Fm: NEG 53

Harder Fjord fault zone: cNG 53

Hareelv Fm (Jurassic): cEG 56, 87

Hauge Bjerge Fm (Silurian): NG 47

Hecla High: $s$ WG 76, 76

Heimbjerge Fm (Ordovician): NEG 50

Hellefisk Structure: sWG 89

Hellefisk-1 exploration well: sWG 76, 88

Herlufsholm Strand Fm (Cretaceous): cNG, eNG 54

Hesteelv Fm (Cretaceous): cEG 56

Hold with Hope: NEG 61, 62

Holocene (Quaternary) 63

Hovgård Ridge: NEG 70

Hyaloclastite (Tertiary)

cWG 59, 60

sEG 61

Hydrocarbon exploration, concession areas 87

Hydrocarbon potential 9, 84, 87, 88, 90

Hydrocarbons 87-90

Hyolithus Creek Fm (Cambrian): NEG 50

\section{I}

Iapetus Ocean 50

Ice-core records 65

Ika: SWG 79

Ikermiut Basin: sWG 85,89

Ikermiut Fault Zone: sWG 89

Ikermiut-1 exploration well: sWG 71, 76, 88, 89

Ikkattoq gneisses (Mesoarchaean): cWG 20

Ilimaussaq: SG $35,79,80,82$

Ilímaussaq intrusion (Gardar): SG 35

Ilivertalik augen granite (Mesoarchaean): sWG 16, 21

Illinoian (Quaternary) 63

Illorsuit: SG 79

Ilukunnguaq: cWG 79

Ilulissat Graben: cWG 89 
Ilulissat High: cWG 89

Imilik intrusion (Tertiary): SEG $\mathbf{6 2}$

Independence Fjord Gp (Palaeo-Mesoproterozoic): cNG, eNG 33, $34,35,40,51$

Independence Fjord: cNG 34

Inglefield orogenic belt (Palaeoproterozoic): NWG 14, 14, 15, 21, 27

Ingolf Fjord: eNG 34

Inland Ice

bedrock below 32

former extent $63,63,65$

GISP core 14,32

mass balance 64,65

size 13

thickness 64

volume 64

Iron: NWG, cWG, sWG, SWG, NEG 79

Iron deposit

Banded iron formation (Archaean): sWG, cWG, NWG 17, 17, $26,27,80$

Skaergaard (Eocene): sEG 83

Iron ore exploration 78

Iron province, Melville Bugt: NWG 81

Island arcs $17,19,80$

Isua: $s$ WG 79

Isua supracrustal sequence (Eoarchaean): sWG 17, 17, 18, 80

Isukasia: sWG 14, 16, 17, 18, 79, 80

Isukasia terrane: sWG 16

Itilli: cWG 79

Itilli Fm (Cretaceous): cWG 57, 58

Itilli oil type 89,90

Itsaq Gneiss Complex (Eoarchaean): sWG 18

Ivigtut cryolite deposit (Gardar): SWG 78, 79, 80, 82

Ivisaartoq: cWG 79

Ivittuut: SWG 79

Ivittuut block: SWG 16

\section{J}

Jameson Land Basin: cEG 55, 55, 74, 79, 85

petroleum potential $\mathbf{8 5}, 86$

Jan Mayen Fracture Zone: NEG $66,67,69,74$

Jan Mayen microcontinent (Norway-Iceland) 66, 67, 69

Josephine Headland Fm (Meso-Neoroterozoic): NWG 40

Julianehåb batholith (Palaeoproterozoic): SG 15, 16, 28, 29, 30, 78

Julianehåb granite: SG 29

Jurassic, sediments

cNG, eNG 53, 54, 54

NEG, cEG $55,55,56,56,57,74,74,86,87,91$

sWG 76

Jyske Ås Fm (Neoproterozoic): cNG, eNG 42

\section{$\mathbf{K}$}

Kakortokite (Gardar): SG 35

Kangaamiut Basin: sWG 85

Kangâmiut dykes (Palaeoproterozoic): sWG 22, 36, 37

Kangâmiut-1 exploration well: sWG 76, 88, 89

Kangeq sequence (Cretaceous): sWG 76, 76, 89, 90

Kangerlussuaq Gp (Cretaceous-Palaeogene: sEG 60
Kangerdlugssuaq intrusion (Palaeogene): sEG 62

Kangerluk Structure: cWG 89

Kangerluluk: SEG 79

Kangerlussuaq (airport): sWG 4, 16

Kangerlussuaq Basin: sEG 79

Kangersik Kiatteq: cEG 2, 31, 38, 39

Kangilia Fm (Cretaceous-Paleocene): cWG 57, 58, 59

KANUMAS $66,72,73,76,87,90$

KANUMAS preference areas 87

Kap Alexander: NWG 40

Kap Alexander Fm (Mesoproterozoic): NWG 40

Kap Bernhard Fm (Neoproterozoic): cNG, eNG 42

Kap Dalton: sEG 62

Kap Dalton Gp (Eocene): sEG 62

Kap Edvard Holm intrusion (Palaeogene): sEG 62,79

Kap Graah Gp (Devonian): NEG 53, 53

Kap Gustav Holm intrusion (Palaeogene): sEG 62

Kap Holbæk Fm (Cambrian): NG 41, 41

Kap København Fm (Plio-Pleistocene): cNG 62, 63

Kap Kolthoff Gp (Devonian): NEG 53, 53

Kap Parry intrusion (Palaeogene): NEG 62

Kap Simpson intrusion (Palaeogene): NEG 62

Kap Stewart Gp (Triassic-Jurassic): cEG 56, 87

Kap Trautwine Fm (Meso-Neoproterozoic): NWG 40

Kap Washington: cNG 53

Kap Washington Gp (Paleocene): cNG 48, 53, 54

Kap York: NWG 40

Kap York meta-igneous complex (Neoarchaean): NWG 27

Kapisilik terrane: $s W G \quad 16$

Karrat: cWG 79

Karrat Gp (Palaeoproterozoic): cWG, NWG 14, 15, 25-27, 27, 28

Karrat Isfjord: cWG 27

Karstryggen: cEG 79

Kennedy Kanal (Channel): NWG 49, 69, 72

Ketilidian front: SWG 16

Ketilidian orogen: SEG, SG 14, 14-16, 21, 22, 24, 28-30, 30 gold mineralisation: SG 78,81

Kialineq intrusion (Palaeogene): sEG 62

Kigarsima nappe: cWG 28

Kimberlite: sWG 36, 37, 44

diamond exploration: sWG 78, 80, 82

Kimmeridgian marine mudstones: EG 86, 87

Kirkespirdalen gold deposit (Nalunaq): SG 78, 81

Kitsissut sequence (Cretaceous), offshore: sWG 75, 76, 89

Kitsissut (Carey Islands): NWG 77

Kivioq Basin: NWG 77, 85

Kivioq Ridge: NWG 77

Kløftelv Fm (Cambrian): NEG 50

Knipovich Ridge (Svalbard) 69, 70

Kobberminebugt: SG 79

Koch, Lauge 11

Kolbeinsey Ridge (Iceland) 66, 69

Koldewey Platform: NEG 74

Kome Fm (Cretaceous): cWG 57, 58

Kong Oscar Fjord Gr: NEG 50, 51

Kort \& Matrikelstyrelsen (KMS: National Survey and Cadastre) 13

Kronprins Christian Land: eNG 34, 35, 40, 41, 45, 46, 47, 51, 


\section{3, 74}

'Kronprins Christian Land orogeny': eNG 55

Krummedal supracrustal sequence (Mesoproterozoic): cEG, NEG 2, $38,38,39,39,41,50,51$

Kvanefjord block: SWG 16

\section{$\mathbf{L}$}

Labrador Sea 69, 70-72, 76, 85, 88, 90

Ladegårdsåen Fm (Jurassic): cNG 54, 54

Lady Franklin Basin: sWG 76, 85

Lamproites: cWG 36, 37

Lamprophyres: sWG, SWG 37, 44, 82

Langø: NWG 79

Laurentia 14, 50

Laurentian Shield 9, 14

Lead: NG, cWG, NEG 26, 78, 79

Lead-zinc deposits

Citronen Fjord: cNG 78, 79, 82

Maarmorilik (Sorte Engel): cWG 79, 80, 81

Mestersvig: NEG 79, 83

Legend concept 11-13

Licensing rounds, hydrocarbon exploration 87,88

Lilloise intrusion (Palaeogene): sEG 62

Lincoln Sea (Hav): NG 69, 73, 85

Lincoln Sea Basin: NG 73, 77, 85

Lindemans Bugt Fm (Jurassic-Cretaceous): NEG 56

Lithium, prospect/deposit: SG 82

Liverpool Land Basin: cEG 74, 75, 75, 85

petroleum potential 87

Llandovery (Silurian): NG 47

Lomonosov Ridge: NG 69, 73, 77

Ludlow (Silurian): NG 47

Lujavrite (Gardar): SG 35

Lyell Land Gp (Proterozoic): NEG 42, 43, 44

\section{M}

M'Clintock orogeny (Ordovician), Canada

Maarmorilik: cWG 79

lead-zinc deposit 80,81

Maarmorilik Formation: cWG 27

Maastrichtian (Cretaceous): cWG 57, 58, 59

Magnetic data 24, 24, 66, 67, 69-72, 74, 76, 84, 88, 90

Magnetochrons 70, 71

Majuagaa: sWG 79

Makkovik orogen (Canada) 15

Maligât Fm (Paleocene): cWG 58, 60

Mallemuk Mountain Gp (Carb.-Permian): cNG, eNG 53, 54, 54

Malmbjerg: cEG 79

molybdenum deposit: cEG 80,83

Maniitsoq block: sWG 16, 21

Maniitsoq High: sWG 76

Marinoan (c. 635 Ma; Tillite Gr) 41-43

Markham Fold Belt (Ordovician), Canada 49

Mârmorilik Fm (Proterozoic): cWG 26, 78

Mass balance of Inland Ice 64, 65

'MD' dykes (Palaeoproterozoic): sWG, SWG 37

Melville Bugt: NWG 4, 76, 79, 85
Melville Bugt Fault: NWG 77

Melville Bugt Graben: NWG 76, 77, 77, 85

Melville Bugt Ridge: NWG 77

Merqujôq Fm (Silurian): NG 48

Mesoarchaean

supracrustal rocks 19

gneisses 19

intrusive rocks 19,21

Mesoproterozoic rocks 33-35, 35, 38, 39, 40, 41, 44, 49, 50, 79 mineral deposits 80,82

Mesozoic sedimentary onshore basins

EG $55,55,56,56,60$

NG $53,54,54,55$

WG $57,58,59,59$

Mesozoic sediments, offshore basins: EG, WG 75, 76, 87

Mestersvig: cEG 4, 79

lead-zinc deposit 78, 79, 80

Midsommersø Dolerites (Mesoproterozoic): cNG, eNG 33, 34, 37,40

Milne Land: cEG 79

Mineral deposits

chromium 79, 80

coal $57,58,79,80,83$

cryolite $78,79,80,82$

diamonds $44,78,79,80,82$

gold $78,79,80-83,81$

iron $17,17,27,78,79,80,81,83$

lead $26,78,79,80-83$

molybdenum 79, 80, 83

PGE (platinum group elements) 78, 79, 83

platinum $78,79,83$

silver $79,81,82$

uranium 79,82

zinc $78,79,80-83$

Mines 79, 80-83, 81

Miocene (Tertiary)

glaciation 63

intrusion 83

offshore: cEG, WG 75, 90

volcanic rocks $61,68,69$

Mohns Ridge 69, 70

Moho 72

Molloy Fracture Zone (Svalbard) 69

Molybdenum: sEG, cEG 78, 79, 83

Molybdenum deposit (Malmbjerg): cEG 79, 80, 83

Morænesø Fm (Neoproterozoic): cNG 41, 41

Moriusaq: NWG 79

Morris Bugt Gp (Ordovician-Silurian): cNG, wNG 45, 46

Morris Jesup Rise: cNG 69, 70

\section{$\mathbf{N}$}

Nagssugtôq subbasin: sWG 89

Nagssugtoqidian front: sWG 16

Nagssugtoqidian orogen (Palaeoproterozoic): cWG, sWG, SEG 14, $21,22-25,23,24,25,36$

mineral deposits 80,82

Nalunaq: SG 79 
gold mine (Kirkespirdalen) 78, 81

Nansen Fjord: cEG 60

Nares Land: cNG 46

Nares Stræde (Nares Strait): NWG, wNG 4, 66, 69

Nares Strait geological structure: NWG, wNG 72, 73

Nares Strait Gp (Meso-Neoproterozoic): NWG 37, 40, 40

Narsaq: SG 35, 82

Narssârssuk Gp (Neoproterozoic): NWG 40, 40

Narwhale Sound Fm (Ordovician): NEG 50

Naternaq: cWG 79

Nathorst Land Gp (Neoproterozoic): NEG 42, 43

National Survey and Cadastre (KMS) 13

Nationale Geologiske Undersøgelser for Danmark og Grønland, De 2,4

Naujaite (Gardar): SG 35

Navarana Fjord: cNG 79

Neill Klinter Gp (Jurassic): cEG 56

Neoarchaean 15

supracrustal rocks 19,81

gneisses $19,20,81$

intrusive rocks 20, 21, 36

Neogene (Tertiary) 73, 74, 75, 77, 86, 87, 90

Neoproterozoic

sedimentary onshore basins

NWG 39,40

EG 41, 43

NG 40,41

orogeny (Grenvillian) 38, 39, 50, 51

intrusions 82

Neria terrane: SWG 16

Nertiit Kangersivat: cEG 61

Nesmith Beds (Canada) 45

Net-veined intrusions (Proterozoic): SG 29

New Quebec orogen (Canada) 15

Niaqornaarsuk: SG 79

Nickel, prospect: cWG, sWG, SG, SEG 79

Niggli Spids thrust sheet: cEG, NEG 39, 51

Niobium, prospect/deposit: sWG, SG 79, 80, 82

Nordre Isortoq steep belt: $s$ WG 15

Nordvestfjord: cEG 2, 31, 38, 39

North Atlantic craton 15, 16, 26, 27

North Atlantic D surveys (NAD project) 66

North Ungava Basin (Canada) 89

North Water Bay: NWG 69, 77

Northumberland Fm (Meso-Neoproterozoic): NWG 40

Nualik intrusion (Palaeogene): sEG 62

Nûkavsak Fm (Palaeoproterozoic): cWG 26, 27

Nukik-1 \& 2 exploration wells: sWG 88

Nunaoil A/S 66

Nuuk Basin: sWG 76, 85

Nuuk: sWG 4, 14, 16, 85, 87

Nuup Kangerlua (Godthåbsfjord): sWG 16

Nuussuaq Basin: cWG 57, 58, 59, 59, 76, 79, 89

core wells 86

offshore 76, 89, 90

Nuussuaq Group (Cretaceous-Palaeogene): cWG 57

\section{O}

Ocean Drilling Program (ODP) 66, 67, 75

Ocean floor ridges $66,67,69,70,73,77$

Oceanic crust $13,66,67,68,69,69,70-73,74,75,77,87,88$

Ocean-to-continent transition zone $13,66,67,68,69,77$

ODP see Ocean Drilling Program

Offshore 66-77

geology 68,85

sedimentary basins 85

Oil (petroleum potential) 84-91

Oil seeps $84,86,89,90$

Oil showings $86,89,90$

Oligocene hiatus offshore: WG 76

Olivine deposit, Niaqunngunaq/Fiskefjord: sWG 79, 82

Olympen Fm (Jurassic): cEG 56

Onshore sedimentary basins, see Sedimentary basins, onshore

'Open-door' areas, hydrocarbon exploration 87,88

Ordovician

carbonate sediments: NG $41,45,46,47,49$

clastic sediments: NG $\quad 46,48$

deep-water trough: NG 46,48

carbonate sediments: NEG 50, 50, 51

'Fossilik': sWG, see Legend explanation [9] sediments: NEG 71, 75, 110

offshore: WG 71,75

sediments with mineral deposits 78,82

$\mathbf{P}$

Paamiut Basin: sWG 85

Paamiut terrane: SWG 16

Pacific fauna 50

Palaeogene 12, 57-62, 86

sediments $57,58,60,62,74,75,76,84,86,89$

volcanic rocks $61,61,68,69,71,74,74,79$

intrusions $62,62,67,78,79$

mineral deposits 83

Palaeoproterozoic

unfolded sediments $33,34,35,41$

supracrustal rocks $23,26,28,30$

intrusive rocks 24, 27, 29

Palaeoproterozoic orogenic belts 79

Basement in Caledonian fold belt: cEG, NEG 31, 32, 52

Inglefield orogenic belt: NWG 27, 28

Ketilidian orogen: SG, SEG 28-30, 81

Nagssugtoqidian orogen: cWG, sWG, SEG 22-24

Nagssugtoqidian in Ammassalik region: SEG, sEG 24

Rinkian fold belt: cWG, NWG 25-27, 78

Palaeozoic

fold belts: NG, NEG 49, 50, 51

sedimentary basins, see Sedimentary basins

Paleocene sediments

eNG 55

cWG 58, 86, 89, 90

offshore: WG, NEG 74, 75, 76, 76

SEG 60

Paleocene

volcanic rocks: cNG 54, 71 
intrusions: $s E G \quad 62$

oceanic crust $68,69,72$

Palladium, prospect/deposit: sEG, cWG 79, 83

Palnatokes Bjerg Fm (Jurassic): NEG 56

Pandora Havn Fm (Meso-Neoproterozoic): NWG 40

Paradisfjeld Gp (Cambrian): cNG 45, 46, 48

Passive margins: EG, WG, NG 27, 45, 70

Peary Land Gp (Silurian): NG 46, 47, 48

Peary Land: cNG 4, 33, 46, 48, 53

Pearya (Canada) 48, 49

Peralkaline rocks

Ilímaussaq intrusion (Gardar): SW 35, 79

Kap Washington Gp (Paleocene): cNG 54

Peridotite 23, 70, 71

Permian sediments

cEG, NEG 55, 55, 56, 56, 57, 73, 74, 86, 87

cNG, eNG 53, 54, 54, 57, 86

Petermann Halvø Fm (Silurian): NG 45, 46

Petroleum appraisal (by US Geological Survey) 84,87

Petroleum exploration licences $84,87,88$

Petroleum potential 85

NG 84

NEG $84-88$

WG $86,88-91$

Phosphor: cWG 79

Picrite (Palaeogene): cWG, cEG 60,61

Pillow lavas

Archaean

cWG, Disko Bugt 26

sWG, Isua 17, 19

Palaeoproterozoic

NEG 43

cWG, Aasiaat/Egedesminde 23

SWG 29

Mesoproterozoic

NG, Zig-Zag Dal 35

Pingo Dal Fm (Triassic): cEG 56

Pituffik (Thule Air Base): NWG 4

Place names $13,69,78,79,113$

Platinum, prospect/deposit: cWG, sWG, SEG, sEG 78, 79, 83

Plays (petroleum) 86

Pleistocene sediments (Quaternary): cNG 62, 63, 74, 75, 87

Pliocene sediments (Neogene): cNG 62, 63, 68, 69, 75, 90

Polkorridoren Gp (Cambrian): cNG 45, 46, 48

Portfjeld Fm (Cambrian): cNG, eNG 41, 42, 45, 46, 49

Precambrian Greenland shield 12, 21, 31, 33, 39, 54, 84

Pridoli (Silurian): wNG 48

Prospecting activities 9, 78, 82

Proterozoic sediments in Caledonian fold belt

Neoproterozoic: cEG, NEG 41, 42

Mesoproterozoic: cEG, eNG, NEG 33, 38, 39

Proterozoic unfolded units

Neoproterozoic

sedimentary basin, Thule Basin: NWG 39

sedimentary basin, Hagen Fjord Basin: NG 40

Mesoproterozoic

basalts: NG, SG 33, 34, 35

Gardar Province: SG 35, 38 sedimentary basins: NG, NEG, SG, NWG 33, 35, 38, 39

Prøven igneous complex (Palaeoproterozoic): NWG 14, 15, 26, 27

Pseudo-escarpment (PSE): EG 67, 75

Pulaskite (Gardar): SG 35

Pull-apart basin: eNG 53, 54, 77

\section{Q}

Qaanaaq Fm (Meso-Neoproterozoic): NWG 40

Qaqqaarsuk: sWG 79

Qaqarssuk carbonatite complex (Jurassic): sWG 44, 82

Qarliit Taserssuat assemblage: sWG $\quad 16,19$

Qeqertarssuaq Fm (Palaeoproterozoic): cWG 26, 27

Qeqertarsuup Tunua (Disko Bugt): cWG 4, 14, 15

Qôrqut granite complex (Neoarchaean): sWG 16, 21

Quaternary 63

Quikavsak Fm (Paleocene): cWG 57, 58, 59, 59

Qulleq-1 exploration well: cWG 68, 69, 71, 76, 88

Qullissat: cWG 79

Qullissat coal deposit (Cretaceous): cWG 80, 83

Qussuk: sWG 79

\section{$\mathbf{R}$}

Rae craton (Canada) 15, 26, 27

Rapakivi 'granite' (Palaeoproterozoic): SEG, SG 28, 30, 30, 38

Rare-earth element, prospect/deposit: sWG, SG, cEG 79, 80, 82

Raukelv Fm (Jurassic): cEG 56

Ravnefjeld Formation (Permian): cEG 87

Rensselaer Bay Fm (Meso-Neoproterozoic): NWG 40

Reservoir rocks 84, 86, 88-91

Reykjanes Ridge (Iceland) 67, 69

Rift basins

EG 55,86

WG $73,75,90$

Rinkian fold belt (Proterozoic): cWG, NWG 14, 14, 21, 25, 26, 28

Rivieradal Gp (Neoproterozoic): eNG 41, 41, 51

Robertson Fjord Fm (Meso-Neoproterozoic): NWG 40

Ruby, prospect/deposit: sWG 79, 80, 81

Ryder Gletscher Gp (Cambro-Ordovician): NG 45, 46

\section{$\mathbf{S}$}

Saalian (Quaternary) 63

Salt formation (see also evaporates) 73

Samuelsen Høj Fm (Silurian): cNG, eNG 47

Sangamonian (Quaternary) 63

Saqqaq: cWG 79

Sarfartoq: sWG 79

Sarfartoq carbonatite complex (Neoproterozoic): sWG 44, 79, 82

Sea-floor spreading $60,66,67,68,69-73,69,77$

Seaward-dipping reflectors $66,67,68,69,75$

Sedex-type sulphide deposit: cNG 82

Sedimentary basins

offshore

Blosseville Kyst Basin: cEG, sEG 75, 85, 88

Kivioq Basin: NWG 77, 85

Lady Franklin Basin: sWG 76, 85

Liverpool Land Basin: cEG 74, 75, 75, 85, 87

onshore

Franklinian Basin: NG 45-48, 84 
Jameson Land Basin: cEG 55, 55, 56, 56, 74, 79, 86, 87

Kangerlussuaq Basin: sEG 60

Nuussuaq Basin: cWG 57, 58, 59, 76, 79, 89, 90

Palaeozoic, Kong Oscar Fjord Gp: EG 50, 51

Wandel Sea Basin: cNG, eNG 48, 53, 54, 54, 55, 74, 84, 85

Wollaston Forland: NEG 55, 56

petroleum potential $84-90$

Seismic data

offshore $66,67,69,70,73-76,87,88,90$

onshore 86

Seqi: sWG 79

Seqi Olivine Mine, Niaqunngunaq/Fiskefjord: sWG 79, 82

Sermiligaarsuk terrane: SWG 16

Sermilik block: sWG 16

Sermilik: SEG 25

Sillisissanguit: SWG 79

Sills, see Dykes and sills

Silurian: NG

carbonate sediments $45,46,47,49,51,84,85$

turbidite trough $45-48,46,48,51,78,85$

Silver, prospect/deposit: cWG, sEG 79, 82

Sinarsuk: sWG 79

Singertât complex (Neoarchaean): SEG 21

Sioraq terrane: SWG 16

Sisimiut Basin: sWG 85, 89

Sisimiut intrusive complex (Palaeoproterozoic): sWG 24

Skærgaard: sEG $\quad 62,79$

Skaergaard intrusion (Eocene): sEG $\quad 62,62,78,79,83$

gold and platinum deposit: sEG 79, 83

Skagen Gp (Cambrian): NG 45, 48

Skjoldungen intrusions (Neoarchaean): SEG 21

Skolithos: NEG 43

Slibestensfjeldet Fm: cWG 57, 58

Slottet Fm (Cambrian): NEG 43

Smallefjord sequence (Neoproterozoic): NEG 39

Smith Sound: NWG 69, 72

Smith Sound Gp (Meso-Neoproterozoic): NWG 37, 40, 40

Sodalite foyaite (Gardar): SG 35

Soft-bodied fossil fauna: cNG 45

Sonntag Bugt Fm (Meso-Neoproterozoic): NWG 40

Sortebakker Fm (Carboniferous): eNG 53, 54

Sortis Gp (Palaeoproterozoic): SWG 29, 29

Source rocks (oil and gas) 84

offshore 87-91

onshore 84,86

Spitsbergen Fracture Zone (Greenland-Svalbard) 69, 70

Spreading axis $67,68,69,71-73,85$

Spreading ridge 67,70

Stendalen: SG 79

Storø: sWG 79

Structural trend lines 13

Sunrise Pynt Straight Belt (Palaeoproterozoic): NWG 28

Svalbard (Norway) 38, 69, 70, 85

Svartenhuk Formation (Paleocene): cWG 60

Sverdrup Basin (Arctic Canada) 77, 90, 91

\section{$\mathbf{T}$}

Taartoq: SWG 16,79
Tantalum, prospect/deposit: sWG, SG 79, 80, 82

Tarssartôq dykes (Palaeoarchaean): sWG 37

Târtoq Gp (Mesoarchaean): SWG 16, 19

Taserssuaq tonalite (Mesoarchaean): sWG 16, 21

Tasiilaq: SEG 79

Tasiusarssuaq terrane (Archaean): sWG 16

Tavsen Iskappe Gp (Cambro-Ordovician): cNG, wNG 45, 46

'TD' dykes (Cretaceous): sWG, SWG 37

Tectono-metamorphic provinces 12

Terranes

Archaean 15, 16, 17, 19-21

Palaeozoic 48, 49

Tertiary, mainly Palaeogene 60-63

basalts

cWG 60

EG 61, 62

offshore: EG 74, 85

offshore: WG 76, 85

dykes and sills: EG 37,62

intrusions: EG 62

sediments

onshore

cWG $57,58,59$

eNG 53, 54, 55, 62

SEG 60

offshore

EG $73-75$

WG 75-77

volcanics: EG, WG 85

Thetis Basin: NEG 74, 85

Thorium, prospect/deposit: SG 79, 82

Thule Air Base (Pituffik) 4

Thule SGp (Meso-Neoproterozoic): NWG 39, 40, 40, 77

Thyra Ø Fm (Palaeogene): eNG 54, 55

Tikiusaaq carbonatite complex (Jurassic): sWG 44, 82

Tillite Gp (Neoproterozoic): cEG, NEG 41-43, 43, 51

Tillitic rocks

cNG 41

NEG 42,43

Titanium, prospect/deposit: 79,83

Topographic base 13

Toqqusap Nunaa: sWG 22

Trail Ø Group (Carboniferous): NEG 53

Transform faults $13,67,68,69,70,72,76$

Transition zone, offshore $13,66,67,77$

Transitional crust $67,68,69,69,70,71,73$

Tre Brødre: sWG 16

Tre Brødre terrane: $s$ WG $\quad 16,17,20$

Triassic sediments

cEG $56,56,87$

cNG, eNG 53, 54, 54

NEG 56, 57

NWG 91

Trolle Land fault zone: cNG, eNG 53

Trolle Land Gp (Permo-Triassic): cNG 53, 54, 54

Tupertalik carbonatite (Mesoarchaean): sWG 21, 44

Turbidite flysch

Cambro-Silurian: NG 41, 45, 46, 46, 47, 48, 48 
Palaeoproterozoic: sWG, cWG 23, 26

Cretaceous: cWG, SEG 57, 58, 59, 60

Palaeogene: cWG 89, 90

\section{$\mathbf{U}$}

Ubekendt Ejland: cWG 60

Umîvik dykes (Palaeoproterozoic): sEG, SEG 37

Ungava Fracture Zone 69, 71, 76, 89, 90

Upernavik: NWG 4, 14, 85

Upernivik Ø: cWG 28

Uranium, prospect/deposit: SG 79,82

Uranium concentrations in stream sediments: WG 21

UTM projection 13

Uummannaq: cWG 14

\section{V}

Vaigat Fm (Paleocene): cWG 58, 59

Vallen Gp (Palaeoproterozoic): SWG 28, 29

Vanadium, prospect/deposit: sWG, sEG 79, 83

Vandredalen thrust sheet: eNG 40, 41

Vardekløft Fm (Jurassic): cEG 56

Victoria Fjord: cNG, wNG 14, 14, 48

Vilddal Gp (Devonian): NEG 52, 53

Vølvedal Gp (Cambro-Ordovician): cNG, wNG 46, 46, 48

\section{W}

Wandel Dal: cNG 41

Wandel Sea Basin: cNG, eNG 48, 53, 54, 54, 55, 74, 84, 85

Wandel Sea strike-slip mobile belt: NG 53

Wandel Valley Fm (Ordovician): NG 41

Washington Land: wNG 45, 46, 79, 82

Washington Land Gp (Silurian): NG 47

Weichselian (Quaternary) 63, 65

Wells, exploration, offshore $66,68,69,71,73,75,76,84,87,88$, 89,89

Wells, exploration, onshore $58,59,86,87$

Wenlockian (Silurian): NG 47

Werner Bjerge complex (Tertiary): cEG 62

Windows in Caledonian orogen: NEG, cNG 31, 43, 50, 51

Wisconsinan (Quaternary) 63

Wolfram, prospect: sWG, cEG, NEG 79

Wollaston Forland (Jurassic-Cretaceous): NEG 55, 56

Wolstenholme Fm (Meso-Neoproterozoic): NWG 40

Wordie Creek Fm (Triassic): cEG 56

Wulff Land: wNG 46

\section{$\mathbf{Y}$}

Yermak Plateau (Svalbard) $\quad 69,70$

Ymer Ø: NEG 79

Ymer $\varnothing$ Gp (Neoproterozoic): NEG 42, 43, 44

Ymers Gletscher Fm (Silurian): cNG 45, 46

Yttrium, prospect 82

\section{$\mathbf{Z}$}

Zig-Zag Dal Basalt Fm (Mesoproterozoic): cNG, eNG 33, 35, 40, 41,51

Zinc, prospect/deposit: NG, cWG, NEG 26, 78, 79, 80-83

Zirconium, prospect/deposit: SG, cEG 79, 80, 82 